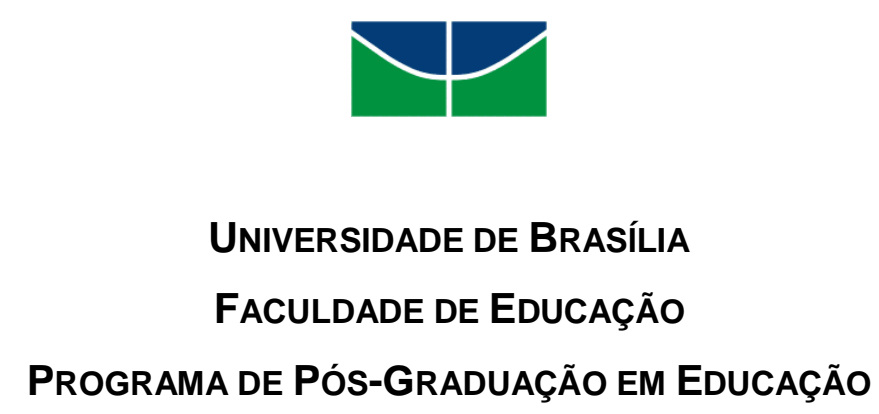

GESTÃO ESCOLAR NO PROCESSO DE INSERÇÃO DE
PROFESSORES INICIANTES NO TRABALHO DOCENTE

ADRIANA REZENDE VARGAS

ORIENTADORA: Prof ${ }^{a}$ Drª. Kátia Augusta Curado Pinheiro Cordeiro da Silva

Brasília - DF

2016 


\title{
GESTÃO ESCOLAR NO PROCESSO DE INSERÇÃO DE PROFESSORES INICIANTES NO TRABALHO DOCENTE
}

\begin{abstract}
Projeto de Pesquisa apresentado ao Programa de Pós-Graduação Strictu Sensu da Faculdade de Educação da Universidade de Brasília - UnB, como requisito parcial para obtenção do título de Mestre em Educação na linha de Pesquisa em Profissão Docente, Currículo e Avaliação - PDCA.
\end{abstract}

Orientadora: Prof $\stackrel{\text { a }}{\text { Dr }}{ }^{\mathrm{a}}$. Kátia Augusta Curado Pinheiro Cordeiro da Silva.

Brasília - DF 


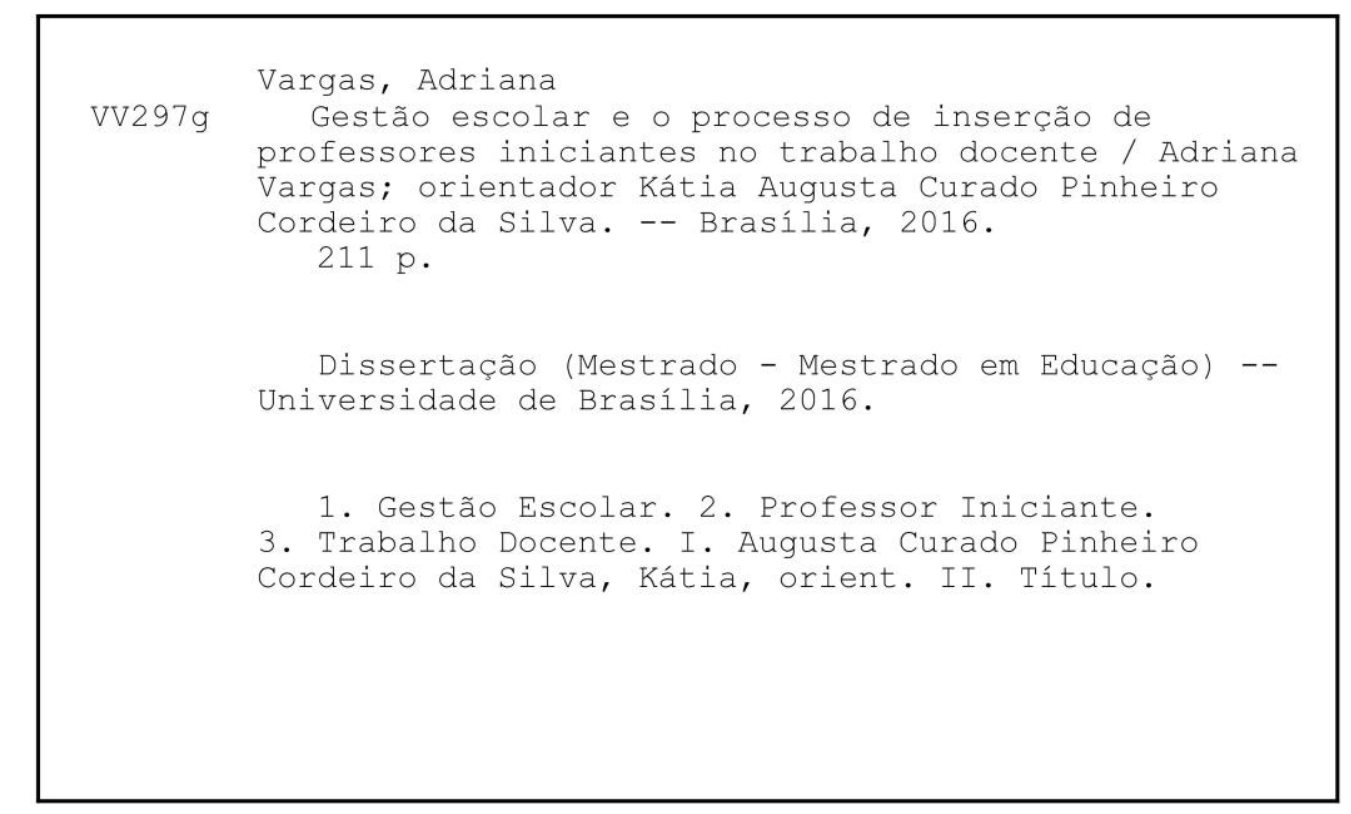


Pesquisa de autoria de ADRIANA REZENDE VARGAS, intitulada GESTÃO ESCOLAR NO PROCESSO DE INSERÇÃO DE PROFESSORES INICIANTES NO TRABALHO DOCENTE, apresentada ao programa de Pós-Graduação Strictu Sensu da Faculdade de Educação da Universidade de Brasília - UnB, como requisito parcial para obtenção do título de Mestre em Educação na linha de Pesquisa em Profissão Docente, Currículo e Avaliação, sob orientação da Profạ. Dr ${ }^{a}$. Kátia Augusta Curado Pinheiro Cordeiro da Silva, defendida e aprovada em 16/03/2016, pela banca examinadora constituída por:

\section{BANCA EXAMINADORA:}

$\overline{\text { Prof }^{\mathrm{a}} \text { Dra }}$. Kátia Augusta Curado Pinheiro Cordeiro da Silva (FE - UnB) - Presidente

Prof $^{\mathrm{a}}$ Dr ${ }^{\mathrm{a}}$. Nancy Nonato de Lima Alves (FE - UFG) - Examinadora Externa

Prof ${ }^{a}$ Dr ํ․ Maria Abádia da Silva (FE - UnB) - Examinadora Interna

Prof $^{\mathrm{a}} \mathrm{Dr}^{\mathrm{a}}$. Shirleide Pereira da Silva Cruz (FE - UnB) - Suplente 


\section{AGRADECIMENTOS}

Ao longo da vida, sempre tive pessoas com quem contar e a quem muito agradecer! Uns, de algum modo, sempre estão por perto, outros passam rapidamente deixando suas marcas, há aqueles que se eternizam na memória e alguns, creio, sempre leais, nos acompanham até o fim.

Neste pequeno espaço deixo registrada a minha mais genuína GRATIDÃO, àqueles que amo e quero bem e que de algum modo contribuíram para tornar esta conquista algo muito especial.

A Deus criador, pela vida, pelas bênçãos concedidas, minha fé e gratidão!

Aos meus pais, pelo esforço e dedicação, muito obrigada!

Ao meu admirável esposo, sempre tão sabiamente colaborativo, paciente e incentivador, que diariamente me dá provas do seu amor pelo simples desejo de me ver feliz. Meu eterno amor, respeito e admiração!

Às minhas duas lindas princesas, preciosas e abençoadas filhas, que carinhosamente chamo de "Presente de Deus" e "Gota Divina", o meu incondicional amor de mãe. Amo vocês!

À minha querida amiga e orientadora, Prof. ${ }^{a}$ Dr. ${ }^{a}$ Kátia, com quem muito aprendi, agradeço e parabenizo pelo profissionalismo, empenho e dedicação. Obrigada!

Aos velhos amigos e parentes, que me querem bem e se alegram com as minhas conquistas, sempre especiais e solícitos, obrigada!

Aos amigos que fiz no percurso, obrigada! Que nossa amizade cresça junto com o nosso conhecimento e sabedoria!

Aos companheiros de profissão e colaboradores desta pesquisa, professores iniciantes e incansáveis gestores escolares, meus agradecimentos e felicitações pelo engajamento e coragem na luta pela educação.

A todos, muito obrigada pelas contribuições que deram sentido à minha história nesse caminhar! 
"Todos os nossos esforços, sem unidade de plano e sem espírito de continuidade, não lograram ainda criar um sistema de organização escolar, à altura das necessidades modernas $e$ das necessidades do país".

(Demerval Saviani) 


\section{RESUMO}

O processo de inserção na carreira docente se constitui em uma etapa profissional peculiar devido às condições de incertezas e insegurança estabelecidas na relação teoria e prática, em que o profissional realiza descobertas e diferentes identificações com a carreira que repercutirão na sua relação com o trabalho e seus respectivos resultados. Considerando as fases do ciclo de vida profissional definido por Huberman (2000) e suas implicações no desenvolvimento do trabalho docente, esta pesquisa analisa a atuação da gestão escolar das escolas públicas de ensino do Distrito Federal no processo de inserção do professor iniciante no trabalho docente. Para tal, como concepção de análise científica no campo das pesquisas sociais, realiza uma aproximação ao materialismo histórico dialético e adota a análise de conteúdo para realizar a investigação na totalidade do contexto escolar e sua realidade histórica, concreta e dialética. Metodologicamente, utiliza questionário semiestruturado e entrevistas para sua composição evidenciando a natureza da função do gestor, as perspectivas do trabalho e da rotina escolar, as dimensões do processo de inserção na carreira e as mediações interativas ocorridas entre gestor e professor iniciante.

Palavras-chave: Gestão Escolar, Professor Iniciante, Trabalho Docente. 


\begin{abstract}
The process of immersion in a teaching career is a peculiar professional step, due to the uncertain and insecure conditions stablished in the relationship between theory and practice, in which the teacher performs discoveries and develops different identifications with the career that will influence his relationship with the job and its respective outcomes. Considering the steps of the professional life cycle defined by Huberman (2000) and its implications in the professional development of the teacher, this research intends to understand the role of management in public schools in Brazil's Federal District in the process of immersion of new teachers in the workplace. For that end, as the conception of the scientific analysis in the field of social research seeks an approximation to the historical dialectic materialism and adopts content analysis in order to investigate the whole scholar context and its historical, concrete and dialectical reality. In terms of methodology, this paper uses a semi structured questionnaire and interviews to compose the research, focusing on the nature of the manager's function, the initiating teacher's job and scholar routine perspectives, the dimensions of the insertion process in the career and the interactive mediations between the manager and the initiating teacher. This work intends to contribute to management related discussions, and also, to reflect on initiating teachers' professional circumstances and their respective needs.
\end{abstract}

Key-words: School Management, Initiating Teacher, Teaching. 


\section{LISTA DE SIGLAS E ABREVIAÇÕES}

ANEC

ANPED

BDTD

CAPES

CEDES

CEDUC

$\mathrm{CNPq}$

CRE (s)

CONGREPRINCI

CONSED

DF

DODF

EAPE

EJA

ENDIPE

FE

FURB

GDF

GEPFAPe

GT

IBICT

INEP

LDBN

MEC

OCDE

PDCA
Associação Nacional de Educação Católica do Brasil

Associação Nacional de Pesquisa de Pós-Graduação em Educação

Biblioteca Digital Brasileira de Teses e Dissertações

Coordenação de Aperfeiçoamento de Pessoal de Nível Superior

Centro de Estudos Educação e Sociedade

Centro de Documentação e Informação em Educação

Conselho Nacional de Desenvolvimento Científico e Tecnológico

Coordenação (ões) Regional (is) de Ensino

Congresso Internacional sobre Professorado Principiante e Inserção Profissional à Docência

Conselho Nacional de Secretários de Educação

Distrito Federal

Diário Oficial do Distrito Federal

Escola de Aperfeiçoamento dos profissionais da Educação do DF

Educação de Jovens e Adultos

Encontro Nacional de Didática e Prática de Ensino

Faculdade de Educação

Fundação Universidade Regional de Blumenau

Governo do Distrito Federal

Grupo de Estudo e Pesquisa sobre Formação e Atuação de Professores/Pedagogos

Grupo de Trabalho

Instituto Brasileiro de Informação em Ciência e Tecnologia

Instituto Nacional de Estudos e Pesquisas Educacionais AnísioTeixeira

Lei de Diretrizes e Bases da Educação Nacional

Ministério da Educação

Organização para Cooperação e Desenvolvimento Econômico

Profissão Docente, Currículo e Avaliação 
PDAF

PPGE

PPP

PUCRS

PUCSP

RBCE

RBEP

RBPG

SEDF

TALIS

ter

UCDB

UCG

UEMA

UEPG

UFAL

UFES

UFGD

UFMA

UFMG

UFPB

UFSCar

UFSM

UnB

UNESCO

UNISC

UNISINOS

USP
Programa de Descentralização Administrativa e Financeira

Programa de Pós-Graduação em Educação

Projeto Político Pedagógico

Pontifícia Universidade Católica do Rio Grande do Sul

Pontifícia Universidade Católica de São Paulo

Revista Brasileira do Esporte

Revista Brasileira de Estudos Pedagógicos

Revista Brasileira de Pós-Graduação

Secretaria de Estado de Educação do Distrito Federal

Teaching and Learning International Survey - Pesquisa internacional sobre ensino e aprendizagem

Tribunal Regional Eleitoral

Universidade Católica Dom Bosco

Universidade Católica de Goiás

Universidade Estadual do Maranhão

Universidade Estadual de Ponta Grossa

Universidade Federal de Alagoas

Universidade Federal do Espírito Santo

Universidade Federal da Grande Dourados

Universidade Federal do Maranhão

Universidade Federal de Minas Gerais

Universidade Federal da Paraíba

Universidade Federal de São Carlos

Universidade Federal de Santa Maria

Universidade de Brasília

Organização das Nações Unidas para a Educação, Ciência e Cultura

Universidade de Santa Cruz do Sul

Universidade do Vale do Rio dos Sinos

Universidade de São Paulo 


\section{LISTAS DE ILUSTRAÇÕES}

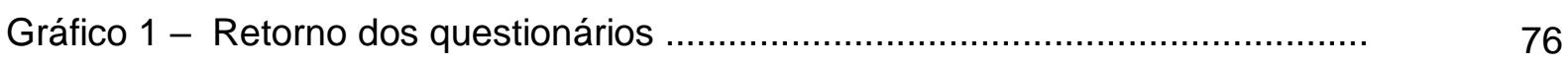

Gráfico 2 - Professores iniciantes/ingressantes ............................................. $\quad 76$

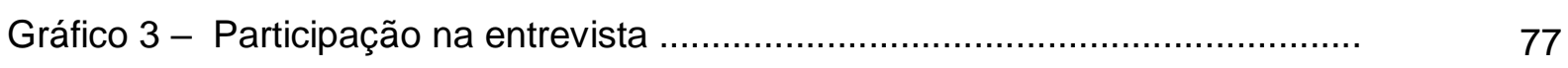

Gráfico 4 - Experiência dos gestores na função ….........................................

Gráfico 5 - Experiência como gestor na atual unidade escolar ............................ 80

Gráfico 6 - Panorama das mulheres em gestão escolar .................................. 81

Gráfico 7 - Gênero na docência .................................................................

Gráfico 8 - Atividades administrativas e pedagógicas ....................................... 108

Gráfico 9 - Incidência de atividades do gestor ................................................. 110

Gráfico 10 - Receptividade pelos membros da escola ....................................... 113

Gráfico 11 - Dificuldades do professor iniciante ........................................... 123

Quadro 1 - Coerência entre tema e objetivo geral ............................................ 16

Quadro 2 - Coerência entre objetivos específicos e metodologia ......................... 17

Quadro 3 - Síntese ANPED .....................................................................

Quadro 4 - Síntese ENDIPE ..................................................................

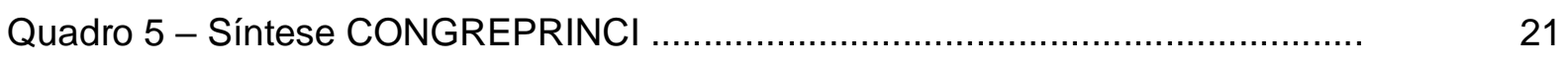

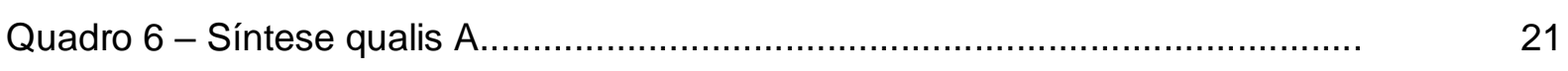

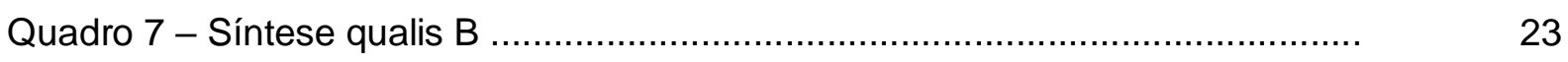

Quadro 8 - Síntese dissertações e teses ....................................................

Quadro 9 - Resumo do estado da arte ............................................................ 26

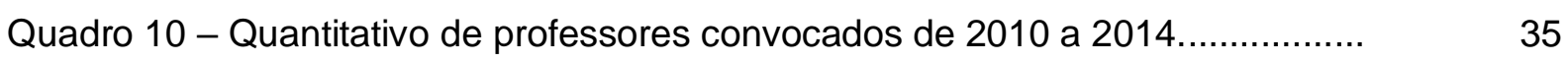

Quadro 11 - CREs selecionadas para amostra .............................................. 36

Quadro 12 - Localização das CREs no mapa do DF .......................................

Quadro 13 - Destinação e permanência de professores para o período ................ 38

Quadro 14 - Aplicação do questionário ........................................................... 38

Quadro 15 - Condição de professor iniciante .................................................. 39

Quadro 16 - Total de entrevistas ................................................................. 39

Quadro 17 - CREs de lotação e remoção ........................................................... 41

Quadro 18 - Relação entre fontes de coleta de dados e objetivos da pesquisa ... $\quad 45$

Quadro 19 - Concepções de organização e gestão escolar.................................. 58

Quadro 20 - Fases da carreira docente - Huberman 2000.............................. 70

Tabela 1 - Motivo da escolha profissional ....................................................... 88

Tabela 2 - Perspectiva da função do gestor escolar ........................................ 97

Tabela 3 - Atividades desenvolvidas pelos gestores escolares .......................... 109

Tabela 4 - Recepção na escola ...................................................................... 112

Tabela 5 - Informações recebidas pelos professores na chegada à escola............ 116 


\section{SUMÁRIO}

INTRODUÇÃO ........................................................................................... 11

1. ETIOLOGIA, NATUREZA E CONTEXTO DA PESQUISA............................ 14

1.1 Gênese do objeto e suas implicações........................................... 14

1.2 Estado da arte ............................................................................... 18

1.2.1 Eventos........................................................................ 19

1.2.2 Periódicos........................................................................... 21

1.2.3 Dissertações e teses......................................................... 24

1.3 Perspectiva epistemológica .......................................................... 26

1.4 Percurso metodológico................................................................. 34

2. GESTÃO ESCOLAR EO PROFESSOR INICIANTE ................................ 47

2.1. O gestor escolar, seu papel e a legitimação de sua atividade................ 47

2.1.1 Gestor ou administrador? Uma terminologia em discussão.......... 55

2.1.2 A natureza constitutiva do gestor escolar no Distrito Federal........ 60

2.2. A condição de professor iniciante e seu contexto profissional no DF..... 69

3. O SENTIDO DO OBJETO A PARTIR DOS RESULTADOS ......................... 75

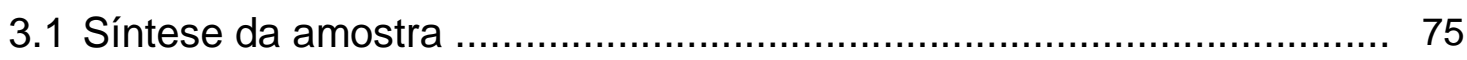

3.2 O perfil dos sujeitos no contexto da pesquisa .................................. 78

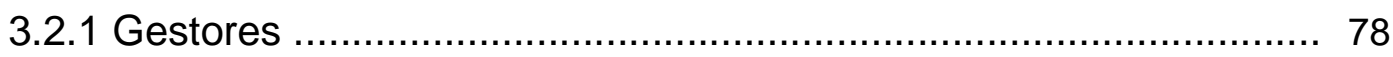

3.2.2 Professores iniciantes.................................................. 86

3.3 Dialogando com as concepções evidenciadas ................................ 93

3.3.1 A natureza da função do gestor escolar .................................... 94

3.3.2 Perspectivas das atividades e rotinas escolares...................... 106

3.3.3 As dimensões do processo de inserção na carreira ................... 112

3.3.4 Mediações interativas no desenvolvimento do trabalho docente .. 120

CONSIDERAÇÕES REFLEXIVAS ........................................................... 126

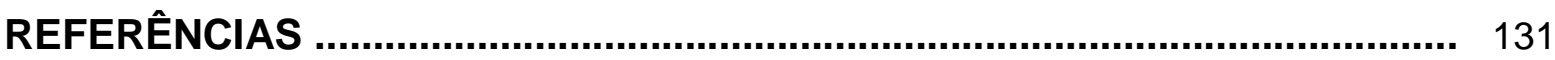

APÊNDICES............................................................................................. 135

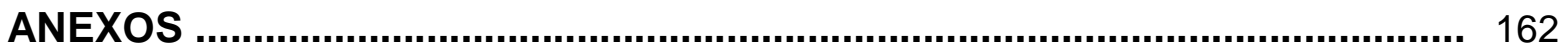




\section{INTRODUÇÃO}

Pesquisas contemporâneas no campo educacional revelam que as condições de professores iniciantes, profissionais que nunca atuaram na docência e vivenciam sua primeira experiência na regência de classe, encontram diversas dificuldades, mas também realizam descobertas e diferentes identificações no momento inicial da efetivação profissional docente. $\mathrm{O}$ professor iniciante se constitui em um profissional que ainda não vivenciou experiências docentes, diferenciando-se do professor ingressante que "já vivenciou um ou mais ciclos de aprendizagem profissional" (CURADO SILVA; FREITAS, 2014, p. 13).

$O$ processo de inserção do professor iniciante na carreira pode ser estabelecido de maneira estável ou não e, dependendo de como ocorra, pode influenciar no entusiasmo e na motivação do professor, conduzindo-o a atitudes e definições que repercutirão em sua vida profissional. Assim, há que se analisar as relações estabelecidas por esses sujeitos junto aos demais no contexto profissional, dando atenção às suas circunstâncias logo no momento inicial da atividade docente.

Por questões administrativas, esse professor geralmente se apresenta primeiro à equipe gestora da unidade de ensino ao estabelecer seu contato com a escola. Como a gestão escolar tem o princípio de articular e integrar o trabalho das pessoas assegurando o bom funcionamento da instituição com vistas ao alcance dos objetivos educacionais esperados, o gestor escolar, como seu representante, pode articular e mediar a transição entre a formação inicial e a incorporação ao mundo do trabalho docente, o que contribuiria no desenvolvimento profissional desse professor.

Diante disso identifica-se uma questão a ser investigada: Como é a atuação da gestão escolar das escolas públicas do Distrito Federal no processo de inserção do professor iniciante no trabalho docente?

O processo de iniciação profissional se constitui em momento ímpar na carreira do indivíduo, visto que estabelece elo entre o sentido daquilo que se construiu no processo de formação, ao mesmo tempo em que projeta sonhos e ideais no desenvolvimento profissional, consolidando um projeto de vida. 
Esse momento inicial da carreira, tido como etapa de inserção, não apresenta consenso quanto à sua duração. Assim, este estudo limita-se aos 05 (cinco) primeiros anos da carreira- considerada uma média relevante entre vários autores- e fundamenta-se na teoria de Huberman (2000), observando que esse período se associa ao início da primeira fase ("Entrada, Tacteamento") e se finaliza na metade da segunda fase ("Estabilização, Consolidação de um repertório pedagógico").

Em colaboração com o trabalho do GEPFAPe, esta pesquisa enfoca a dimensão da gestão escolar por acreditar na relevância da temática para o meio acadêmico, social e científico, destina-se a um estudo no campo educacional e insere-se na linha de pesquisa de Profissão Docente, Currículo e Avaliação - PDCA, junto ao Programa de Pós-Graduação em Educação - PPGE Stricto Sensu da FE/UnB.

Para tal, como concepção de análise científica no campo das pesquisas sociais, busca-se uma aproximação ao materialismo histórico dialético, tentando realizar uma investigação da totalidade do contexto escolar em sua realidade histórica, suas contradições e mediações estabelecidas em meio ao movimento dialético presente cujo cenário é repleto de múltiplas determinações, com desafios e dilemas constantes, sobretudo no início da carreira.

Como eixos de análise para responder a questão de pesquisa, emergiram do objeto as seguintes categorias:

- Função do gestor (a natureza da função do gestor escolar);

- Trabalho escolar (perspectivas das atividades e rotinas escolares);

- Ingresso profissional (as dimensões do processo de inserção na carreira);

- Relacionamento profissional (mediações interativas no desenvolvimento do trabalho docente).

Do ponto de vista dos instrumentos metodológicos, a pesquisa emprega uma revisão bibliográfica e documental, utiliza questionários semiestruturados e entrevistas, adotados para interpretação dos resultados por meio da análise de conteúdo, associada a abordagem analítica do materialismo histórico dialético. Esta 
análise tomou o período de 2010 a 2014 como marco temporal e tem como sujeitos professores iniciantes e seus respectivos gestores.

A organização deste trabalho se dá em três capítulos. O primeiro tem por finalidade apresentar a origem, o contexto e a natureza do objeto, retratando sua relevância acadêmica, científica e social, indicando a gênese da pesquisa, as implicações do estudo e as produções acadêmicas/científicas já realizadas. Além disso, evidencia a proposta epistemológica adotada e descreve o percurso metodológico empregado.

O segundo capítulo empenha-se em compor um diálogo entre fundamentações teóricas e categorias de análise, contextualizando a gestão escolar, o papel do gestor e a legitimidade da função no âmbito pedagógico e administrativo, na perspectiva teórica e prática e sua ressonância no âmbito do Distrito Federal. Revela-se também a condição do professor iniciante dentro da profissão, seus dilemas e dificuldades e sua singularidade no processo de inserção profissional na Secretaria de Educação do Distrito Federal - SEDF.

O terceiro capítulo tem por objetivo realizar a apreciação dos resultados, procurando aproximar a realidade declarada às discussões e às fundamentações teóricas encontradas, analisando o sentido do objeto a partir dos resultados.

Assim, enseja-se colaborar com o eixo de estudo do desenvolvimento profissional docente, aprofundando um aspecto do contexto educacional e estimulando a investigação, o debate e a reflexão sobre a temática. 


\section{ETIOLOGIA, NATUREZA E CONTEXTO DA PESQUISA}

O conhecimento reflete o contexto no qual é produzido... E tem caráter coletivo, mesmo quando formulado ou definido por um único homem.

(Moroz, 2006)

Dividido em quatro subseções, este capítulo tem as seguintes finalidades: 1) Demonstrar o interesse, relevância, objetivo geral e específico do estudo; 2) Mostrar o estado da arte em consonância com a temática; 3) Rever a perspectiva epistemológica do método; e 4) Delinear percurso metodológico adotado com definição da amostra, sujeitos e instrumentos de análise.

\subsection{Gênese do objeto e suas implicações}

São constantes as discussões sobre melhoria dos sistemas educacionais no país e, impulsionados pelo desafio de alcançar êxito, os debates crescem e muito se tenta fazer para alcançar sucesso nesta área. As escolas se esforçam, a sociedade vem sendo impelida a se envolver com a temática e o meio acadêmico procura constantemente compreender e estabelecer conhecimentos científicos que venham a auxiliem ações relevantes para sanar os dilemas e contradições da educação.

Contudo os desafios cada vez mais se ampliam. Seja por razões pertinentes ao ato de ensinar e aprender, seja por razões sociais edificadas no seio de uma sociedade capitalista, fomentada tecnologicamente e cada vez mais antagônica, preocupar-se com os problemas na área, acaba sendo uma ação frequente de educadores e teóricos. Propor soluções e alternativas que levem à melhoria da qualidade de vida dos indivíduos torna-se objeto de motivação para aqueles que enxergam na educação um caminho para minimizar as injustiças sociais.

O desejo de compreender e transformar o contexto educacional vislumbrando avanços pedagógicos e administrativos fomenta os estudos acadêmicos, fazendo com que pesquisadores se submetam a jornadas de trabalho longas, exaustivas e talvez sem fim, mas extremamente valorativas para o desenvolvimento social.

E é com esse desejo de contribuir por meio de uma pesquisa que nos valemos de aporte teórico e científico, visando a analisar a atuação da gestão escolar no processo de 
inserção do professor iniciante no trabalho docente tendo o cenário educacional do Distrito Federal - DF - como espaço de observação e estudo.

Imersa na área como pedagoga por formação acadêmica, com aproximadamente 16 anos de exercício na SEDF, e trabalhando em diversas funções (professora, coordenadora e gestora escolar) e em contextos escolares distintos, sinto-me sujeito e agente nesse universo repleto de paradoxos a serem explorados.

Tenho uma longa experiência como gestora num transcurso de aproximadamente 10 anos e acompanhei sistematicamente a atuação de professores dentro do universo escolar. Isso me fez conhecer suas demandas conforme seu grau de experiência, e assim, observar o professor iniciante, ou seja, aquele professor que, embora formado, ainda não tenha atuado e está se iniciando no trabalho docente.

Notando que esses geralmente se apresentam entusiasmados e motivados, seja pelo fato de a admissão the possibilitar a condição de empregabilidade e estabilidade, seja pela oportunidade de exercer a profissão adquirida no curso de graduação (formação inicial)e atuar na área profissional desejada e conquistada, seja por outras razões, o fato é que a motivação interna, a disposição para o trabalho e entusiasmo profissional, em grande maioria, ficam evidenciados em suas atitudes e comportamentos quando do ingresso na SEDF.

Outro aspecto também percebido é a dificuldade de estabelecer a relação teoria e prática, devido à inexperiência e à ausência de contato com o universo escolar, o que acaba por prejudicar o desenvolvimento do seu trabalho e, muitas vezes, resval na sua permanência na carreira.

Huberman (2000), em seu estudo sobre o ciclo de vida profissional, aponta que as adversidades podem influenciar no entusiasmo do professor, e

[...] docentes que, não tendo podido chegar tão longe quanto as suas ambições os teriam conduzido, desinvestem já a meio da carreira, ou que desiludidos com os resultados do seu trabalho, ou das reformas empreendidas, canalizam para outros lados as suas energias (HUBERMAN, 2000, p. 46).

O desenvolvimento da carreira é um processo que possui uma série de acontecimentos com características peculiares a cada etapa, que nem sempre são vividas de maneira igual e na mesma ordem para todos, 
[...] para alguns, este processo pode parecer linear, mas, para outros, há patamares, regressões, becos sem saída, momentos de arranque, descontinuidade. $O$ facto de encontrarmos sequências-tipo não impede que muitas pessoas nunca deixem de praticar a exploração, ou que nunca estabilizem, ou que desestabilizem por razões de ordem psicológica (tomada de consciência, mudança de interesses, ou de valores) ou exteriores (acidentes, alterações políticas, crise econômica) (HUBERMAN, 2000, p. 38)

Lima e Corsi (2006) alegam que as dificuldades variam individualmente, mas há aquelas que mais se destacam: a imitação acrítica; o isolamento; a dificuldade em estabelecer disciplina e regras; problemas na motivação e trato com as características individuais; impasses no relacionamento com seus pais, alunos, comunidade e professores; insegurança em relação à própria competência e a visão pessimista em relação à docência. É claro que muitas dessas dificuldades não ocorram somente no início da docência, mas podem ser mais problemáticas para os professores iniciantes.

Portanto, é necessário o aprofundamento na condição desse professor, investigando os diversos aspectos que o envolvem e afetam o seu desenvolvimento profissional, as estruturas educacionais e os processos educativos.

Por acreditar na relevância da temática, seu valor social, acadêmico e científico, esta pesquisa traz a seguinte questão central: Como é a atuação da gestão escolar das escolas públicas de ensino DF no processo de inserção do professor iniciante no trabalho docente? Consequentemente conduzindo ao seguinte

\section{objetivo geral:}

- Compreender a atuação da gestão escolar na Secretaria de Educação do Distrito Federal junto ao professor iniciante, investigando o processo de inserção no trabalho docente, considerando o desenvolvimento da atividade pedagógica e o início da carreira profissional.

\section{Quadro 1 - Coerência entre tema e objetivo geral}

\begin{tabular}{|c|c|c|}
\hline TEMA & QUESTÃO CENTRAL & OBJETIVO GERAL \\
\hline $\begin{array}{c}\text { Gestão escolar no } \\
\text { processo de inserção } \\
\text { de professores } \\
\text { iniciantes no trabalho } \\
\text { docente }\end{array}$ & $\begin{array}{|lrr|}\text { Como é a atuação da } \\
\text { gestão escolar das escolas } \\
\text { públicas de ensino DF no } \\
\text { processo de inserção do } \\
\text { professor iniciante no } \\
\text { trabalho docente? }\end{array}$ & $\begin{array}{l}\text { Compreender a atuação da gestão escolar na } \\
\text { Secretaria de Educação do Distrito Federal } \\
\text { junto ao professor iniciante, investigando o } \\
\text { processo de inserção no trabalho docente, } \\
\text { considerando o desenvolvimento da atividade } \\
\text { pedaqógica e o início da carreira profissional. }\end{array}$ \\
\hline
\end{tabular}

Fonte: Elaborado pela autora da pesquisa. 
Apoiado pelas seguintes questões secundárias:

- Qual a prescrição legal para a gestão escolar em relação ao trabalho docente?

- Como o gestor escolar percebe a sua atuação em relação ao trabalho docente de professores iniciantes?

- Como a gestão escolar institui o processo de inserção profissional do professor iniciante na SEDF?

Logo, os objetivos específicos decorrentes constituem-se em:

- Examinar a prescrição legal para a gestão escolar em relação ao trabalho docente;

- Entender como o gestor escolar percebe a sua atuação junto ao professor iniciante em relação ao seu trabalho docente;

- Explicitar como ocorre a atuação da gestão escolar no processo de inserção do professor iniciante na SEDF.

Assim, temos:

Quadro 2 - Coerência entre objetivos específicos e metodologia

\begin{tabular}{|l|l|c|}
\hline \multicolumn{1}{|c|}{ QUESTÕES SECUNDÁRIAS } & \multicolumn{1}{|c|}{ OBJETIVOS ESPECÍFICOS } & METODOLOGIA \\
\hline $\begin{array}{l}\text { Qual a prescrição legal para a gestão } \\
\text { escolar em relação ao trabalho } \\
\text { docente? }\end{array}$ & $\begin{array}{l}\text { Examinar a prescrição legal para a } \\
\text { gestão escolar em relação ao } \\
\text { trabalho docente; }\end{array}$ & $\begin{array}{l}\text { Revisão Bibliográfica } \\
\text { Análise documental }\end{array}$ \\
\hline $\begin{array}{l}\text { Como a gestor escolar percebe a sua } \\
\text { atuação em relação ao trabalho } \\
\text { docente de professores iniciantes? }\end{array}$ & $\begin{array}{l}\text { Entender como o gestor escolar } \\
\text { percebe a sua atuação junto ao } \\
\text { professor iniciante em relação ao seu } \\
\text { trabalho docente }\end{array}$ & $\begin{array}{c}\text { Questionário } \\
\text { Entrevista }\end{array}$ \\
\hline $\begin{array}{l}\text { Como a gestão escolar institui o } \\
\text { processo de inserção profissional do } \\
\text { professor iniciante na SEDF? }\end{array}$ & $\begin{array}{l}\text { Explicitar como ocorre a atuação da } \\
\text { gestão escolar no processo de } \\
\text { inserção do professor iniciante na } \\
\text { SEDF. }\end{array}$ & $\begin{array}{c}\text { Questionário } \\
\text { Entrevista }\end{array}$ \\
\hline
\end{tabular}

Fonte: Elaborado pela autora da pesquisa.

Desse modo, espera-se que este estudo contribua para ampliar as reflexões sobre o assunto, rumo ao estabelecimento de ações integradas, consistentes e coordenadas na 
direção de processos adequados de inserção na carreira que venham a proporcionar aos professores iniciantes, acolhimento, formação, valorização, incentivo à permanência, melhora no desempenho e desenvolvimento profissional docente.

\subsection{Estado da arte}

Por meio de um amplo levantamento de materiais relacionados à temática, já estudados e publicados por especialistas, tentando não incorrer na repetição ou irrelevância do trabalho, percorreu-se um longo caminho de investigação nas publicações dos anais de eventos, periódicos, dissertações e teses, que dialogam com o campo educacional.

Assim, como "Estado da Arte"1 ou "Estado do Conhecimento" examinaram-se materiais publicados no campo educacional dos últimos 14 (quatorze) anos, 2000 a 2014, em: Eventos (Associação Nacional de Pós-Graduação e Pesquisa em Educação - ANPED-, Encontro Nacional de Didática e Práticas de Ensino ENDIPE - e Congresso Internacional sobre Professorado Principiante e Inserção Profissional à Docência - CONGREPRINCI), Periódicos, publicações realizadas em revistas científicas e classificadas pela Coordenação de Aperfeiçoamento de Pessoal de Nível Superior (CAPES Qualis ${ }^{2}$ A1 e A2 / B1 a B5) e, finalmente, em Dissertações e Teses (Instituto Brasileiro de Informação em Ciência e Tecnologia IBICT - e o Centro de Documentação e Informação em Educação - CEDUC - da Faculdade de Educação - FE - da Universidade de Brasília - UnB).

Esta pesquisa contribuiu com os estudos do Grupo de Estudo e Pesquisa sobre Formação e Atuação de Professores/Pedagogos - GEPFAPe ${ }^{3}$ - da FE/UnB, que está realizando uma pesquisa junto ao Conselho Nacional de Desenvolvimento Científico e Tecnológico - CNPq -, sobre a prática pedagógica de professores que

\footnotetext{
${ }^{1}$ Foi desenvolvido em conjunto com o Grupo de Estudos e Pesquisa sobre formação e atuação de professores/pedagogos - GEPEFAPe - constituindo-se em um banco de dados sobre professores iniciantes.

2 Termo que define um conjunto de procedimentos utilizados pela Capes para estratificação da qualidade da produção intelectual dos programas de pós-graduação.

3 Desenvolve pesquisas sobre Formação de Professores e de Pedagogos, focando nos estudos sobre formação e atuação cujo recorte são as políticas públicas e o currículo.
} 
se iniciam na docência e os desafios e dilemas mais frequentes que esses professores possam vir a enfrentar.

\subsubsection{Eventos - ANPED / ENDIPE / CONGREPRINCI}

A ANPED fundamenta-se na temática da educação e é fonte de pesquisas na área. Assim, em seu acervo disponível, analisou-se da $23^{\underline{a}}$ a $36^{\underline{a}}$ reunião nacional, totalizando 14 (quatorze) encontros anuais. Como essa associação organiza-se em Grupos de Trabalho (GT), investigou-se o GT 08 (oito), que trata da "Formação de Professores", porém não foi encontrada nenhuma publicação que articule as categorias de gestão escolar e professor iniciante, conforme trata esta pesquisa. No entanto, há trabalhos acerca do professor iniciante. Abaixo, segue o quadro de levantamento, sintetizando os resultados encontrados ao longo dos anos pesquisados:

\section{Quadro 3 - Síntese ANPED}

\begin{tabular}{|c|c|c|c|c|}
\hline \multirow[b]{2}{*}{ № } & \multirow[b]{2}{*}{ ANO } & \multirow[b]{2}{*}{ FONTE } & \multicolumn{2}{|c|}{ CATEGORIA } \\
\hline & & & $\begin{array}{l}\text { PROFESSOR } \\
\text { INICIANTE }\end{array}$ & $\begin{array}{l}\text { GESTÃO } \\
\text { ESCOLAR }\end{array}$ \\
\hline 1 & 2000 & 23ㄹ Reunião - Caxambu / MG & - & - \\
\hline 2 & 2001 & 24를 Reunião - Caxambu / MG & - & - \\
\hline 3 & 2002 & 25를 Reunião - Caxambu / MG & - & - \\
\hline 4 & 2003 & 26를 Reunião - Poços de Caldas / MG & - & - \\
\hline 5 & 2004 & 27르 Reunião - Caxambu / MG & 01 & - \\
\hline 6 & 2005 & 28ª Reunião - Caxambu / MG & 03 & - \\
\hline 7 & 2006 & 29를eunião - Caxambu / MG & 02 & - \\
\hline 8 & 2007 & 30ª Reunião - Caxambu / MG & - & - \\
\hline 9 & 2008 & 31 ${ }^{\text {a }}$ Reunião - Caxambu / MG & - & - \\
\hline 10 & 2009 & 32ª Reunião - Caxambu / MG & 01 & - \\
\hline 11 & 2010 & 33ª Reunião - Caxambu / MG & - & - \\
\hline 12 & 2011 & 34를 Reunião - Natal / RN & 01 & - \\
\hline 13 & 2012 & 35 Reunião - Porto de Galinhas / PE & - & - \\
\hline 14 & 2013 & 36" Reunião - Goiânia / GO & 02 & - \\
\hline 15 & 2014 & Não ocorreu ${ }^{4}$ & - & - \\
\hline & & TOTAL & 10 & - \\
\hline
\end{tabular}

Fonte: Elaborado pela autora, a partir dos anais da ANPED.

O ENDIPE, evento bianual e também relevante à área, teve seus anais pesquisados, já que articula estudos que versam sobre a relação do docente com o

\footnotetext{
${ }^{4}$ Nesse ano, não ocorreu o evento, pois ele passou a ser bianual (37ª Reunião em 2015).
} 
seu cotidiano, as tendências educacionais e seus impactos nas escolas e nas práticas pedagógicas, entre outros aspectos do campo educacional. A partir do debate acadêmico/científico, empenha-se no aprimoramento das condições dos trabalhadores da profissão do magistério.

Dividido em eixos temáticos, o evento conta com um eixo exclusivo para a formação docente, o qual foi analisado no período já explicitado, contudo não contém trabalhos articulados com as categorias aqui apontadas, gestão escolar e professor iniciante, conforme dados expressos no quadro que se segue:

\section{Quadro 4 - Síntese ENDIPE}

\begin{tabular}{|c|c|c|c|c|}
\hline \multirow[b]{2}{*}{ № } & \multirow[b]{2}{*}{ ANO } & \multirow[b]{2}{*}{ FONTE } & \multicolumn{2}{|c|}{ CATEGORIA } \\
\hline & & & $\begin{array}{l}\text { PROFESSOR } \\
\text { INICIANTE }\end{array}$ & $\begin{array}{l}\text { GESTÃO } \\
\text { ESCOLAR }\end{array}$ \\
\hline 1 & 2000 & X Encontro - Rio de Janeiro / RJ & - & - \\
\hline 2 & 2002 & XI Encontro - Goiânia / GO & - & - \\
\hline 3 & 2004 & XII Encontro - Curitiba / PR & 01 & - \\
\hline 4 & 2006 & XIII Encontro - Recife / PE & 03 & - \\
\hline 5 & 2008 & XIV Encontro - Porto Alegre / RS & - & - \\
\hline 6 & 2010 & XV Encontro - Belo Horizonte / MG & - & - \\
\hline 7 & 2012 & XVI Encontro - Campinas / SP & 04 & - \\
\hline 8 & 2014 & XVII Encontro - Fortaleza / CE & - & - \\
\hline & & $\begin{array}{ll}\text { TOTAL } \\
\end{array}$ & 08 & - \\
\hline
\end{tabular}

Fonte: Elaborado pela autora, a partir dos anais do ENDIPE.

O CONGREPRINCI, evento bianual, até o momento com 04 edições: Servilha/Espanha/2008; Buenos Aires/Argentina/2010; Santiago/Chile/2012 e Curitiba/Brasil/2014, de abordagem específica relacionada ao início da docência, tem por objetivo disponibilizar espaço de reflexão, além de intercâmbio para investigadores, formadores e docentes preocupados com a formação dos professores que se iniciam na tarefa de ensinar. Foi analisada apenas a $4^{\underline{a}}$ edição ${ }^{5}$ desse evento da qual foram selecionadas 38 (trinta e oito) publicações. Contudo não se evidenciou aqui também, uma discussão diretamente estabelecida entre o gestor escolar e o professor iniciante, conforme demonstra o quadro abaixo:

\footnotetext{
${ }^{5}$ As edições anteriores não foram disponibilizadas no meio virtual e não foi possível o acesso às mídias dos eventos, inviabilizando a análise do referido material.
} 


\section{Quadro 5 - Síntese CONGREPRINCI}

\begin{tabular}{|c|c|c|c|}
\hline \multirow{2}{*}{ ANO } & \multirow{2}{*}{ FONTE } & \multicolumn{2}{|c|}{ CATEGORIA } \\
\cline { 3 - 4 } & & $\begin{array}{c}\text { PROFESSOR } \\
\text { INICIANTE }\end{array}$ & $\begin{array}{c}\text { GESTÃO } \\
\text { ESCOLAR }\end{array}$ \\
\hline 2014 & $4^{\circ}$ CONGRESSO (Brasil - Curitiba) & 38 & - \\
\hline & TOTAL & 38 & $\mathbf{0}$ \\
\hline
\end{tabular}

Fonte: Elaborado pela autora, a partir dos anais do CONGREPRINCI.

\subsubsection{Periódicos - QUALIS A e B}

Quanto aos periódicos, optou-se pelas classificações A e B a partir do site $<$ http://qualis.capes.gov.br/webqualis/principal.seam> selecionando-se 09 (nove) periódicos: 06 (seis) A1 e 03 (três) A2, distribuídos nas seguintes publicações: Qualis A1 - Cadernos de Pesquisa; Ciência \& Educação; Educação em Revista; Educação e Pesquisa; Educação e Realidade; Educação \& Sociedade; Revista do Instituto de Estudos Brasileiros; Educar em Revista; Pró-Posições; Revista Brasileira de Educação e Qualis A2 - Cadernos do Centro de Estudos Educação e Sociedade - CEDES; Educação da Pontifícia Universidade Católica do Rio Grande do Sul PUCRS; Revista Brasileira de História da Educação; Revista Diálogo Educacional.

\section{Quadro 6 - Síntese Qualis A}

\begin{tabular}{|c|c|c|c|}
\hline \multirow{2}{*}{ ANO } & \multirow{2}{*}{ FONTE } & \multicolumn{2}{|c|}{ CATEGORIA } \\
\cline { 3 - 4 } & & PROFESSOR INICIANTE & GESTÃO ESCOLAR \\
\hline 2000 & $\mathrm{~A} 1$ & 01 & - \\
\hline 2001 & - & - & - \\
\hline 2002 & $\mathrm{~A} 1$ & 01 & - \\
\hline 2003 & $\mathrm{~A} 1$ & 01 & - \\
\hline 2004 & $\mathrm{~A} 2$ & 01 & - \\
\hline 2005 & - & - & - \\
\hline 2006 & - & - & - \\
\hline 2007 & A2 & - & - \\
\hline 2008 & - & - & - \\
\hline 2009 & - & 02 & - \\
\hline 2010 & A1 & - & - \\
\hline 2011 & - & $01 / 01$ & - \\
\hline 2012 & A1 / A2 & - & - \\
\hline 2013 & - & - & $\mathbf{0}$ \\
\hline 2014 & - & 09 & \\
\hline TOTAL & A1 + A2 & - A & \\
\hline
\end{tabular}

Fonte: <http://qualis.capes.gov.br/webqualis/principal.seam> 
$\mathrm{Na}$ Qualis A também não foram encontrados materiais que articulem de maneira direta a gestão escolar e o professor iniciante, embora alguns tratem da organização escolar, de políticas e programas de apoio ao professor iniciante no Brasil.

No que tange à Qualis $B$, a investigação perquiriu da classificação 01 (um) a 05 (cinco) contando com a parceria dos alunos da graduação da FE/UnB integrantes do GEPFAPe. Os periódicos foram:

B1 - Educação em Foco (Belo Horizonte, 1996), Educação em Foco (Juiz de Fora), Educação (Universidade Federal de Santa Maria - UFSM), Educação da Universidade do Vale do Rio dos Sinos - Unisinos, Em Aberto, Intercâmbio (Pontifícia Universidade Católica de São Paulo - PUCSP), Linhas Críticas (Universidade de Brasília - UnB), Revista Brasileira de Estudos Pedagógicos RBEP do Instituto Nacional de Estudos e Pesquisas Educacionais Anísio Teixeira INEP, Série Estado do Conhecimento, Sociedade e Estado (UnB, Impresso);

B2 - Atos de Pesquisa em Educação (Fundação Universidade Regional de Blumenau - FURB), Crítica Marxista (São Paulo), Educação em Perspectiva (Impresso), Educação (Rio Claro, Impresso), Educativa (Universidade Católica de Goiás - UCG), Interações (Universidade Católica Dom Bosco - UCDB), Pesquisa em Foco (Universidade Estadual do Maranhão - UEMA), Pesquiseduca, Política \& Trabalho (Universidade de Santa Cruz do Sul - UNISC, Impresso), Trabalho \& Educação (Universidade Federal de Minas Gerais - UFMG);

B3 - Comunicação e Educação (Universidade de São Paulo - USP), Comunicação \& Sociedade, Conhecimento \& Diversidade, Contexto \& Educação Contemporânea (Rio de Janeiro), Educação e Fronteiras (Universidade Federal da Grande Dourados - UFGD), Educação, Formação \& Tecnologias, Formação Docente Olhar de Professor (Universidade Estadual de Ponta Grossa - UEPG, Impresso), Planejamento e Políticas Públicas, Políticas Educativas, Práxis Educacional RBPG Revista Brasileira de Pós-Graduação, Revista de Educação Associação Nacional de Educação Católica do Brasil - ANEC, Revista Enfoques (Rio de Janeiro), Temas em Educação (Universidade Federal da Paraíba - UFPB); 
B4 - Cadernos de Formação RBCE, Cadernos de Pesquisa em Educação do Programa de Pós-Graduação da Universidade Federal do Espírito Santo PPGE/UFES, Cadernos de Pesquisa (Universidade Federal do Maranhão - UFMA), Educação (Universidade Federal de Alagoas - UFAL), Interfaces da Educação, Revista Lugares de Educação, Revista Novos Rumos, Revista Profissão Docente;

B5 - Caderno Pedagógico (Lajeado. Impresso), Cadernos da Pedagogia (Universidade Federal de São Carlos - UFSCar, Online), Formadores (Cachoeira), Saber Acadêmico.

\section{Quadro 7 - Qualis B}

\begin{tabular}{|c|c|c|}
\hline \multirow{2}{*}{ ANO } & \multicolumn{2}{|c|}{ CATEGORIA } \\
\hline & PROFESSOR INICIANTE & GESTÃO ESCOLAR \\
\hline 2000 & - & - \\
\hline 2001 & - & - \\
\hline 2002 & - & - \\
\hline 2003 & - & - \\
\hline 2004 & B1(01) & \\
\hline 2005 & - & - \\
\hline 2006 & B1 (01) & \\
\hline 2007 & B2(01) / B3(02) & B3 (01) \\
\hline 2008 & - & - \\
\hline 2009 & B1(01) & - \\
\hline 2010 & $\mathbf{B} 1(01) / \mathbf{B}(01)$ & - \\
\hline 2011 & B3(01) / B5(01) & - \\
\hline 2012 & B2(01) / B3(02) & - \\
\hline 2013 & B1(02) / B2(01) / B3(02) / B4(04) & - \\
\hline 2014 & - & - \\
\hline TOTAL & 23 & 01 \\
\hline
\end{tabular}

Fonte: <http://qualis.capes.gov.br/webqualis/principal.seam>

De 24 (vinte e quatro) trabalhos selecionados nesse acervo, encontrou-se apenas 01 (uma) publicação que articula a temática da gestão escolar e o professor iniciante intitulado $O$ papel da equipe pedagógica e da direção na atuação de professores iniciantes das séries iniciais do ensino fundamental. Trata-se de um trabalho de conclusão de curso de licenciatura em Pedagogia na Universidade de São Carlos - UFSCar, publicado no ano de 2007. 
O referido estudo investigou o papel da equipe pedagógica e da direção das escolas (diretores, vice-diretores e coordenadores pedagógicos) na atuação de professores iniciantes do ensino fundamental - anos iniciais - no município de São Carlos, em São Paulo, indicando que as escolas,

[...] no papel de seus dirigentes e equipe de coordenação, não oferecem aos professores iniciantes 0 apoio que necessitam para se tornarem bem sucedidos e sentirem satisfação em sua atuação. Mas, além disso, sequer conhecem, com raras exceções, que estes professores têm necessidades formativas específicas que lhes cabe atender para que o sucesso escolar possa ocorrer para todos os alunos (PIERI; TANCREDI, 2007, p. 112).

Essa publicação vem demonstrar que a inquietação suscitada por esta pesquisa já esteve presente em outro contexto. Considerando que ainda não foram evidenciados outros estudos acadêmicos referentes à temática, tal dissonância nos desafia a compreender melhor essa relação e sua relevância no processo de inserção de professores iniciantes no trabalho docente, visto que um único estudo limita a análise e o debate.

\subsubsection{Dissertacõos e teses - CEDUC e IBICT}

No banco de dados do CEDUC/FE/UnB, disponibilizado pelo site <http://www.fe.unb.br/ceduc/catalogos>, constam catalogados trabalhos até 0 ano de 2012. Vale ressaltar que, no caso das teses, os registros iniciaram-se a partir de 2008, assim, foram analisadas 638 dissertações e 63 teses, não sendo constatada nenhuma pesquisa correlata.

No banco da Biblioteca Digital Brasileira de Teses e Dissertações - BDTD - disponível em <http://bdtd.ibict.br>, no período de 2000 a 2014, 23 (vinte e três) dissertações e 07 (sete) teses tratam do processo de iniciação na docência, contudo, mais uma vez, a relação gestor escolar e professor iniciante não foi estabelecida nos estudos examinados, conforme apresentado no quadro: 


\section{Quadro 8 - Síntese dissertações e teses}

\begin{tabular}{|c|c|c|c|c|c|}
\hline \multirow{2}{*}{ ANO } & \multirow{2}{*}{ FONTE } & \multicolumn{4}{|c|}{ CATEGORIA } \\
\cline { 3 - 6 } & & PROFESSOR INICIANTE & \multicolumn{2}{c|}{ GESTÃO ESCOLAR } \\
\cline { 3 - 6 } & & DISSERTAÇÕES & TESES & DISSERTAÇõES & TESES \\
\hline $\mathbf{2 0 0 0}$ & CEDUC/FE/UnB e IBICT & - & - & - & - \\
\hline $\mathbf{2 0 0 1}$ & CEDUC/FE/UnB e IBICT & - & - & - & - \\
\hline $\mathbf{2 0 0 2}$ & CEDUC/FE/UnB e IBICT & 01 (IBICT) & - & - & - \\
\hline $\mathbf{2 0 0 3}$ & CEDUC/FE/UnB e IBICT & - & - & - & - \\
\hline $\mathbf{2 0 0 4}$ & CEDUC/FE/UnB e IBICT & 02 (IBICT) & - & - & - \\
\hline $\mathbf{2 0 0 5}$ & CEDUC/FE/UnB e IBICT & - & 01 (IBICT) & - & - \\
\hline $\mathbf{2 0 0 6}$ & CEDUC/FE/UnB e IBICT & 03 (IBICT) & 01 (IBICT) & - & - \\
\hline $\mathbf{2 0 0 7}$ & CEDUC/FE/UnB e IBICT & 01 (IBICT) & 02 (IBICT) & - & - \\
\hline $\mathbf{2 0 0 8}$ & CEDUC/FE/UnB e IBICT & 01 (IBICT) & 01 (IBICT) & - & - \\
\hline $\mathbf{2 0 0 9}$ & CEDUC/FE/UnB e IBICT & 02 (IBICT) & 01 (IBICT) & - & - \\
\hline $\mathbf{2 0 1 0}$ & CEDUC/FE/UnB e IBICT & 06 (IBICT) & 01 (IBICT) & - & - \\
\hline $\mathbf{2 0 1 1}$ & CEDUC/FE/UnB e IBICT & 01 (IBICT) & - & - & - \\
\hline $\mathbf{2 0 1 2}$ & CEDUC/FE/UnB e IBICT & 01 (IBICT) & - & - & - \\
\hline $\mathbf{2 0 1 3}$ & CEDUC/FE/UnB e IBICT & 05 (IBICT) & - & - & - \\
\hline $\mathbf{2 0 1 4}$ & CEDUC/FE/UnB e IBICT & - & - & - & - \\
\hline & TOTAL & $\mathbf{2 3}$ & $\mathbf{0 7}$ & - & - \\
\hline
\end{tabular}

Fonte: <http://www.fe.unb.br/ceduc/catalogos> e <http://bdtd.ibict.br>

Consolidando o primeiro passo desta pesquisa, pode-se afirmar que a condição de professor iniciante é relativamente nova no universo das discussões acadêmicas e científicas, tendo em vista que num transcurso de 14 (quatorze) anos de publicações em eventos, periódicos e bancos de dissertações e teses, foram encontrados 119 (cento e dezenove) trabalhos com a temática do professor iniciante, discutindo condições de trabalho, exercício profissional, necessidades formativas, profissionalidade, programas de iniciação à docência, representação social e socialização, mas sem articulação com a gestão escolar, conforme proposto por este trabalho.

A evidenciação dos resultados após a investigação demonstra que, embora tenha sido motivo de inquietação de outros pesquisadores, sua limitação de apenas um estudo fragiliza o olhar perante a questão, revelando sua peculiaridade e distinção enquanto objeto de pesquisa. Observe no quadro que se segue como se concretizou o "Estado da Arte" sobre a temática proposta: 
Quadro 9 - Resumo do estado da arte

\begin{tabular}{|c|c|c|c|c|c|c|c|c|}
\cline { 2 - 9 } \multicolumn{1}{c|}{} & \multicolumn{3}{c|}{ EVENTOS } & \multicolumn{2}{c|}{ PERIÓDICOS } & \multicolumn{2}{c|}{$\begin{array}{c}\text { DISSERTAÇÓES } \\
\text { E TESES }\end{array}$} & \\
\cline { 2 - 9 } & ANPED & ENDIPE & CONGREPRINCI & QUALIS A & QUALIS B & DISSERTAÇÖES & TESES & \\
\hline $\begin{array}{c}\text { Professo } \\
r \\
\begin{array}{c}\text { Iniciante } \\
e \\
\text { Outros } \\
\text { Temas }\end{array}\end{array}$ & 10 & 08 & 38 & 09 & 23 & 23 & 07 & 118 \\
\hline $\begin{array}{c}\text { Professo } \\
r \\
\text { Iniciante } \\
e \\
\text { Gestão } \\
\text { Escolar }\end{array}$ & - & - & - & - & 01 & - & - & 01 \\
\hline TOTAL & 10 & 08 & 38 & 09 & 24 & 23 & 07 & 119 \\
\hline
\end{tabular}

Fonte: Elaborado pela autora da pesquisa.

Esse silenciamento em relação à temática causa estranheza, tendo em vista a relevância do trabalho da gestão escolar na "mediação que envolve as atividadesmeio e as atividades-fim, perpassando todo o processo de realização de objetivos" (PARO, 2011, p. 21), bem como de seu papel de envolver e coordenar pessoas.

Conforme vimos, a relação entre professor iniciante e gestão escolar é um objeto pouco explorado em pesquisas. Por esse motivo, este trabalho procura contribuir com o eixo de estudo do desenvolvimento profissional docente, investigando as circunstâncias que envolvem esse profissional em um momento sui generis na carreira, a inserção e, consequentemente, no trabalho docente, que nem sempre é simples, natural e harmonioso como possa parecer.

\subsection{Perspectiva epistemológica}

Ao longo dos anos a Educação sempre se constituiu em terreno propício para estudos e análises devido à sua complexidade enquanto área social. O ser humano, seu principal elemento, se consubstancia a partir de suas interações e modifica suas condições, bem como o espaço que o envolve. Nessa relação "onde os seres sociais tornaram-se mediadores entre si e combinados dentro de uma totalidade social estruturada, mediante um sistema de produção e intercâmbio estabelecido" (ANTUNES, 1999, p.19) é que se amplia o conhecimento humano. 
Para compreender suas próprias lógicas de convívio social, seus dilemas e contradições, o homem busca o aprimoramento, produzindo e se apropriando da ciência, utilizando-a como instrumento para o alcance de seus objetivos.

No campo das peculiaridades das ciências sociais,

[...] muitos pensadores do passado manifestaram a aspiração de definir um método universal aplicável a todos os ramos do conhecimento. Hoje, porém os cientistas e os filósofos da ciência preferem falar numa diversidade de métodos, que são determinados pelo tipo de objeto a investigar e pela classe de proposições a descobrir (GIL, 2008, p. 8).

A fim de desvelar o significado e as inferências do papel do gestor escolar no processo de inserção do professor iniciante no trabalho docente, há de se buscar um aprofundamento em vários elementos presentes nesse contexto, pois a

[...] pesquisa tem de captar detalhadamente a matéria, analisar as suas várias formas de evolução e rastrear sua conexão íntima. Só depois de concluído esse trabalho é que se pode expor adequadamente o movimento real (MARX, 1986, p. 140).

Faz-se necessário, assim, ampliar o olhar sobre o trabalho e o contexto das relações de seus sujeitos, identificando a realidade concreta, aprofundando a compreensão sobre esses elementos, processos e relações, num movimento investigativo que tem por objetivo buscar a totalidade do conjunto que, para Gamboa (2007, p. 35), "está construída e em construção", ou seja, em movimento constante nas relações sociais.

São diferentes as possibilidades de caminhos para a investigação, importando, assim, buscar o mais adequado ao objeto e seu tipo de estudo. Por isso, como aspectos essenciais desta pesquisa, temos o elemento fundante das relações entre sujeitos, o trabalho. Este, por sua vez, está em um determinado contexto historicamente situado.

Evidenciando o seu caráter social, o trabalho "distingue as diferentes épocas econômicas" (MARX, 1989, p. 204) nas quais os meios que o realizam medem o desenvolvimento e indicam suas condições de realização.

Da mesma forma, o trabalho educativo possui suas características peculiares, sua amplitude e suas múltiplas determinações, tornando-se "um fenômeno dinâmico 
e permanente como a própria vida e o educador busca compreender justamente esse fenômeno para compreender melhor o que faz" (GADOTTI, 2012, p.11).

A Educação como elemento social permanente e, ao mesmo tempo, dinâmico, fruto das lutas ideológicas presentes nos interesses diversos da sociedade contemporânea, modifica-se a cada tempo, constituindo-se de diversas maneiras ao longo da história. Fruto das relações de poder, a escola torna-se, ao mesmo tempo, um espaço de reprodução ideológica, mas também de luta e resistência. Esse movimento de disputa gera novas demandas para a área, que se transforma continuamente.

Para pesquisar questões sociais, precisamos interpretar a realidade que se apresenta diante de nossos olhos e que está imbricada de contradições nem sempre perceptíveis a um simples olhar. Ir à materialidade dos fatos e compreender as ideias que as sustentam é, no mínimo, um movimento complexo.

Para Marx (1989, p. 202), o trabalho torna-se elemento fundante do homem que

[...] põe em movimento as forças naturais de seu corpo, braços e pernas, cabeça e mãos, a fim de apropriar-se dos recursos da natureza, imprimindoIhes forma útil à vida humana. Atuando assim sobre a natureza externa e modificando-a, ao mesmo tempo em que modifica sua própria natureza.

É por meio do intercâmbio com a natureza, condição inerente à vida humana, que o homem se torna um ser social. Para Marx e Engels (2007, p. 13), a forma mais apropriada de se compreender a materialidade das relações sociais estaria ligada ao trabalho, ou seja, à "condição de produção e a reprodução das condições de existência dos homens", visto que

Dela decorrem as relações dos homens com a natureza e com suas formas de organização social, isto é, dos sujeitos com o que lhes aparece como a objetividade do mundo. Uma forma específica de apropriação da natureza determina as formas de organização social e a consciência [...] A apreensão do significado que as formas de reprodução da vida têm para a existência humana representa a primeira grande formulação do materialismo dialético para a compreensão da história e da consciência humana. A cada estado de desenvolvimento das formas de produção material da sua existência correspondem formas específicas de estruturação social, além de valores e formas de apreensão da realidade. 
A materialidade expressa na natureza das relações humanas é o referencial concreto que nasce na "produção social de uma sociedade historicamente dada. $E$ as categorias para a sua explicitação e compreensão serão sempre históricas, assim como é histórico o movimento do real" (CURY, 2000, p. 18), pois as ideias e o conhecimento são, na verdade, uma representação da vida do ser humano, num dado momento de sua história.

Investigar o objeto em sua totalidade desvelando as contradições inerentes requer uma análise por categorias e estas, por sua vez, consistem em

[...] conceitos básicos que pretendem refletir os aspectos gerais e essenciais do real e suas conexões e relações [...] não possuem um fim em si mesmas. Elas ganham sentido enquanto instrumento de compreensão de uma realidade social concreta [...] possuem simultaneamente a função de intérpretes do real e de indicadoras de uma estratégia política (CURY, 2000, p. 21).

Assim, as categorias perpassam períodos históricos e relações sociais e somente podem ser analisadas, fazendo uso de uma lógica dialética, que consiste em entender que "tudo está em movimento, que todo movimento é causado por elementos contraditórios coexistindo numa totalidade estruturada" (GADOTTI, 2012, p. 28) e articulados entre a dinamicidade existente nas relações e o movimento histórico em que o homem compreende o objeto na medida em que atua sobre ele.

Portanto, a dialética surge como elemento essencial para o conhecimento do mundo e

[...] diferentemente dos sistemas filosóficos antecedentes, não constrói um quadro universal do mundo. [...]. No entanto, a experiência conjunta do conhecimento e da atividade prática se constitui na base em que a dialética cria as categorias. No sistema de categorias apreendem-se não só os resultados do conhecimento e da prática, mas também as suas tarefas, razão pela qual a dialética materialista é um método do conhecimento científico (KOPNIN, 1978, p. 34).

O materialismo histórico dialético acabou se consolidando num caminho para estudos que envolvam a pesquisa social, e uma de suas bases consiste em "apoderar-se da matéria, em seus pormenores, de analisar suas diferentes formas de desenvolvimento e de perquirir a conexão íntima que há entre elas" (GADOTTI, 2012, p. 32), apontado a visão de totalidade dada ao problema, conduzindo a análise dos elementos presentes nas partes, pois esses revelam a essência do todo. 
A lógica-dialética torna-se fundamental, pois "fornece as bases para uma interpretação dinâmica e totalizante da realidade, já que estabelece que os fatos sociais não possam ser entendidos quando considerados isoladamente" (GIL, 2008, p.14) e fora de um movimento, ou seja, abstraídos de suas influências recíprocas.

A educação, essencialmente concebida no campo social e permeada de relações contraditórias de poder, rupturas e reprodução, traz em sua estrutura elementos complexos e historicamente estabelecidos conforme os valores sociais impregnados em seu contexto social à época. Assim, deve ser analisada a partir de um método científico que permita amplitude e profundidade.

[...] A educação é então partícipe da totalidade da organização social. Essa relação exige que se a considere como historicamente determinada por um modo de produção capitalista, ela tem uma especificidade que só é inteligível no contexto das relações sociais resultantes dos conflitos das duas classes fundamentais. Assim, considerar a educação na sua unidade dialética com a sociedade capitalista é considerá-la no processo das relações de classe, enquanto essas são determinadas, em última instância, pelas relações de produção (CURY, 2000, p. 13).

Devido à natureza social da educação, a priori observa-se que ela carrega princípios que nos remetem às categorias de totalidade, contradição e mediação, contudo, reafirmando nas palavras de Cury (2000, p. 21), "elas não são algo definido de uma vez por todas e não possuem um fim em si mesmo. Elas ganham sentido enquanto instrumento de compreensão de uma realidade concreta", o que a posteriori pode provocar o surgimento de outras categorias emergidas do objeto estudado.

Ao realizar o movimento de análise no campo educacional, é importante, então, contextualizar a abrangência de suas contradições questionando: Quais os interesses presentes na educação? Que interesses ela busca atender? Qual a conduta hegemônica presente? Essa conduta corresponde aos interesses que busca atender? Qual sua conduta diante do que lhe é impelido a corresponder? Adota postura de reprodução ou superação dos problemas?

Conduzindo o pensamento na lógica do questionamento do real, muitas dessas perguntas e outras tantas podem auxiliar na compreensão do objeto estudado, ampliando o olhar a respeito das estruturas pedagógicas e administrativas, das relações humanas e de poder, das condições físicas correspondentes aos interesses objetivados, dos 
processos de inserção e socialização, do trabalho, desenvolvimento e afirmação profissional docente, entre tantos outros aspectos. Todos eles podem surgir na vasta imensidão dos fenômenos educacionais e suas construções embasadas na lógica dialética, pois a "educação é um processo contraditório de elementos subjetivos e objetivos, de forças internas e externas" (GADOTTI, 2012, p.72).

Desse modo, ao analisar o objeto de estudo proposto, que é o papel do gestor escolar no processo de inserção do professor iniciante no trabalho docente, remetese à categoria de totalidade, a partir do momento em que se analisa o contexto no qual esses sujeitos estão inseridos carregando em seu bojo relações de produção, relações sociais e relações político-ideológicas. Cury (2000, p.67) acrescenta que

[...] as relações sociais implicam a ação recíproca e contraditória entre as classes fundamentais. Se tais relações implicam a presença das classes dominantes é porque implicam a presença das classes dominadas. A essência dessas relações, sob o capitalismo, é de serem relações de luta. Esta luta atinge a totalidade da sociedade, afetada pela gestão hegemônica da classe dominante, cujo fundo social é deduzido da mais-valia. Percebese, pois, que as relações sociais são relações econômicas (pela apropriação da mais valia), são relações políticas (pela gestão hegemônica da mais-valia) e são relações ideológicas (pela tentativa de representá-las e difundi-las no modo abstrato). A Educação como conjunto totalizante dessas relações busca compreensão global do fenômeno educativo, como ele se define frente a si e ao todo.

Assim, entende-se que essa totalidade social acaba por interferir na conceituação da função do gestor e, consequentemente, nas suas implicações para a atividade, na condição de trabalho desse gestor, na natureza da função docente, nas condições objetivas de inserção de professores recém-contratados, na permanência e satisfação desse professor dentro da escola pública, na relação que ambos estabelecem no dia a dia escolar. Entende-se também que o momento histórico-social vivenciado, sustentado pelo capitalismo existente e suas consequências para a vida humana, acaba por influenciar a educação, a dinâmica escolar e o trabalho docente.

As contradições - muito presentes na educação através das lutas e resistências e alimentadas por interesses opostos e inconciliáveis entre dominantes e dominados fomentam um movimento dialético de transformações materiais e ideológicas, sempre inacabadas e infinitas, levando a novas mediações entre os sujeitos. 
Ao longo da história, a educação sempre se configurou um campo de grandes conflitos ideológicos, sendo entendida de várias formas e, por isso, servindo a interesses diversos. Saviani (2012) afirma que, em determinados momentos, a educação é entendida como instrumento de correção de distorções sociais e se "constitui, pois, uma força homogeneizadora que tem por função reforçar laços sociais, promover a coesão e garantir a integração de todos os indivíduos no corpo social". Outrora, é vista sob a perspectiva que the qualifica como inteiramente dependente da estrutura social e, portanto, tem a "função de reforçar a dominação e legitimar a marginalização" (SAVIANI, 2012, p.4), contribuindo para um distanciamento entre os indivíduos e fortalecendo as desigualdades sociais. Com essa compreensão, embora a educação seja

[...] determinada unidirecionalmente pela estrutura social, dissolvendo-se a sua especificidade, entende que a educação se relaciona dialeticamente com a sociedade. Neste sentido, ainda que elemento determinado, não deixa de influenciar o elemento determinante (SAVIANI, 2012, p. 66).

A educação como elemento concebido nessa totalidade social que altera e sofre alterações na sociedade acaba por se constituir em palco de lutas ideológicas que devem ser compreendidas objetivando o uso adequado de seus instrumentos de transformação a bem da democracia e da justiça social.

Ao questionar as ideias que estão presentes nos meios educacionais a fim de compreender os reais interesses presentes nas concepções pedagógicas estabelecidas ao longo dos tempos para a educação brasileira, Saviani (2012) traz uma análise interessante e aponta que

[...] é necessário abalar as certezas, desautorizar o senso comum. E para isso nada melhor do que demonstrar a falsidade daquilo que é tido como obviamente verdadeiro, demonstrando ao mesmo tempo a verdade daquilo que é tido como obviamente falso (SAVIANI, 2012, p. 60).

O autor concorda com uma análise que investigue a estrutura educacional por meio das categorias aqui anteriormente mencionadas, reafirmando o caráter contraditório, histórico e dinâmico presente na educação, que deve ser analisado pela ótica da abordagem crítico-dialética a qual

[...] reconhece a ciência como produto da história, da ação do próprio homem, que está inserido no movimento das formações sociais. Nesse sentido, encara a ciência como uma construção decorrente da relação dialética entre o pesquisador 
e o objeto envolvidos em determinada realidade histórica. $O$ processo de construção do conhecimento vai do todo para as partes e depois das partes para o todo, realizando um círculo de síntese conforme o contexto, com necessidade de aproximação e, às vezes, de afastamento do pesquisador em relação ao objeto (CUNHA et al., 2014, p 2).

Realizar o movimento necessário na pesquisa pela vertente do materialismo histórico dialético implica "compreender e transformar o concreto. Para isso deve-se transpor, pela faculdade da abstração, o concreto-dado, produzindo o concretopensado transposto para a mente humana" (CURADO SILVA, 2008, p. 22).

É importante considerar que a teoria que o pesquisador assume dirige todas as suas ações e, consequentemente, o seu caminho metodológico. De acordo com o exposto, para que esta pesquisa seja coerente com seus pressupostos e sirva melhor às suas indagações, objetiva-se um percurso metodológico que se utilizará de análise bibliográfica e documental, entrevistas e questionários.

Para entender a atividade do gestor escolar e suas possibilidades de ação junto ao professor iniciante, teremos que percorrer o caminho das bases históricas que determinaram as relações na sociedade que acabaram sendo reproduzidas nas demais dimensões e relações da vida social e política chegando às escolas.

Métodos e técnicas originariamente empregados nas empresas capitalistas passaram a ser considerados como princípios administrativos de todas as organizações (ANDREOTTI; LOMBARDI; MINTO, 2012) e a escola, é claro, teve sua natureza alterada ao longo da história, o que afetou as relações ali estabelecidas.

Libâneo (2001) afirma que a escola é um elemento de unidade social, que tem por finalidade alcançar determinados objetivos, sendo que a "organização escolar é o conjunto de disposições, fatores e meios de ação que regulam a obra da educação ou um aspecto ou grau da mesma" (p. 77). Essa regulação interfere nos procedimentos administrativos, pedagógicos e financeiros que estão atrelados a uma concepção de uma dada sociedade e suas estruturas.

Saviani (2012, p. 30) assegura que:

A escola é determinada socialmente; a sociedade em que vivemos, fundada no modo de produção capitalista é dividida em classes com interesses opostos; portanto, a escola sofre a determinação do conflito de interesses que caracteriza a sociedade. 
Por consequência, seus agentes também sofrem essas influências, estando a função de gestor e de professor diretamente ligadas às determinações sociais, políticas e econômicas recorrentes no momento histórico-social vivido.

Por isso, a Educação carrega consigo a grande responsabilidade de evidenciar a real opressão presente na sociedade, exercendo um papel contrahegemônico de desvelar processos alienantes e ideologias cotidianamente ocultadas. Isso, ao mesmo tempo em que deve assumir o compromisso de anunciar uma nova ordem social, construída pela práxis humanizadora e coletivizada.

\subsection{Percurso metodológico}

Considerando os objetivos propostos nesta pesquisa, e a fim de captar as múltiplas determinações existentes na relação entre gestor e professor dentro do contexto do início da carreira docente, optou-se por escutar tanto os professores iniciantes quanto seus respectivos gestores escolares (diretor ou vice-diretor), visto que as diferentes perspectivas podem não convergir na mesma linha de pensamento a respeito desta etapa da carreira.

O Distrito Federal, diferentemente das demais unidades federativas do país, une a Educação Básica (Educação Infantil, Ensino Fundamental e Médio) em uma única rede. Nas demais unidades municípios e estados dividem as responsabilidades: ao primeiro cabe a incumbência da Educação Infantil e Ensino Fundamental, ao segundo compete o Ensino Fundamental e o Médio.

A rede do DF conta com 651 (seiscentas e cinquenta e uma) ${ }^{6}$ escolas oficiais distribuídas em 14 Coordenações Regionais de Ensino - $\mathrm{CRE}^{7}$ - que, localizadas nas cidades do DF, em articulação com o nível central, realizam as ações que concretizam as políticas para a educação.

Para efeitos deste estudo, adotou-se o período estabelecido pelo GEPFAPe o qual considera professor iniciante aquele que se encontra nos primeiros 05 anos no exercício da função e que não possua experiências prévias na docência. Embora

\footnotetext{
${ }^{6}$ Informação constante do site oficial da SEDF< http://www.se.df.gov.br/> Acesso em: 18/12/2015.

7 As CREs se constituem em núcleos setorizados de apoio, suporte e orientação às escolas e, quando necessário, articulam as demandas junto à sede da SEDF.
} 
não haja consenso na literatura acerca da duração dessa fase, essa média foi considerada relevante entre os vários autores.

Huberman (2000), por exemplo, considera inicial a fase que se estende até o terceiro ano de profissão; para Cavaco (1995) vai até o quarto ano de exercício profissional; Veenman (1988) argumenta que tal fase se prolonga até o quinto ano; Tardif (2002) defende que esse momento inicial compreende os sete primeiros anos de profissão.

Embora existam muitos trabalhos sobre o professor iniciante com abordagens em aspectos diferentes, que vão desde dificuldades encontradas até a relação teoria e prática, Huberman (2000) realizou um dos mais referenciados estudos do desenvolvimento profissional dos professores analisando, entre outros aspectos, a existência de fases comuns a esses profissionais, caracterizando um ciclo de vida profissional.

Contudo não faremos uso de todo o seu trabalho, visto que o nosso objeto de estudo versa sobre professores iniciantes. Utilizaremos, então, apenas a primeira e a metade da segunda fase dos ciclos denominados por ele como "Entrada na carreira" e "Estabilização, Consolidação de um repertório pedagógico".

Assim, a primeira demarcação de professor iniciante para esta pesquisa se constitui naqueles que ingressaram na SEDF a partir dos concursos realizados pelos Editais Normativos $n^{\circ}$ 01/2010 (DODF n¹07 de 07/06/2010) e n 01/2013 (DODF n²85 de 05/09/2013), com contratações realizadas até 2014.

Foram nomeados 4663 professores no período de 01/02/2011 a 03/10/2014 e distribuídos na rede da seguinte forma:

Quadro 10 - Quantitativo de professores convocados de 2010 a 2014

(continua)

\begin{tabular}{|l|c|c|c|}
\hline $\begin{array}{c}\text { REGIÕES } \\
\text { ADMINISTRATIVAS DO DF/ } \\
\text { CRE }\end{array}$ & $\begin{array}{c}\text { Total de } \\
\text { professores } \\
\text { convocados no } \\
\text { ano de 2010 }\end{array}$ & $\begin{array}{c}\text { Total de } \\
\text { professores } \\
\text { convocados no } \\
\text { ano de 2013 }\end{array}$ & $\begin{array}{c}\text { Professores convocados } \\
\mathbf{( 2 0 1 0 ) + ( 2 0 1 3 )}\end{array}$ \\
\hline CEILÂNDIA & 553 & 283 & 836 \\
\hline PLANALTINA & 234 & 174 & 408 \\
\hline RECANTO DAS EMAS & 237 & 167 & 404 \\
\hline SAMAMBAIA & 247 & 139 & 386 \\
\hline SANTA MARIA & 204 & 155 & 359 \\
\hline GAMA & 179 & 176 & 355 \\
\hline PARANOÁ & 215 & 140 & 355 \\
\hline
\end{tabular}


(continuação)

\begin{tabular}{|l|c|c|c|}
\hline $\begin{array}{c}\text { REGIÕES } \\
\text { ADMINISTRATIVAS DO DF/ } \\
\text { CRE }\end{array}$ & $\begin{array}{c}\text { Total de } \\
\text { professores } \\
\text { convocados no } \\
\text { ano de 2010 }\end{array}$ & $\begin{array}{c}\text { Total de } \\
\text { professores } \\
\text { convocados no } \\
\text { ano de 2013 }\end{array}$ & $\begin{array}{c}\text { Professores convocados } \\
\mathbf{( 2 0 1 0 ) + ( 2 0 1 3 )}\end{array}$ \\
\hline SÃO SEBASTIÃO & 199 & 119 & 318 \\
\hline PLANO PILOTO / CRUZEIRO & 162 & 154 & 316 \\
\hline BRAZLÂNDIA & 163 & 140 & 303 \\
\hline SOBRADINHO & 101 & 87 & 188 \\
\hline NÚCLEO BANDEIRANTE & 62 & 95 & 157 \\
\hline TAGUATINGA & 33 & 93 & 126 \\
\hline GUARÁ & 53 & 58 & 111 \\
\hline SEDE & 38 & 3 & 41 \\
\hline TOTAL GERAL & $\mathbf{2 6 8 0}$ & $\mathbf{1 9 8 3}$ & 4663 \\
\hline
\end{tabular}

Fonte: Elaborado pela autora da pesquisa.

Analisando a distribuição dos professores e considerando que as 05 primeiras CREs juntas correspondem a 51,31\%, isto é, 2393 professores convocados no período. Optou-se por essas regionais por serem as que mais receberam professores iniciantes no período tomado para estudo, conforme demonstra o quadro:

\section{Quadro 11 - CREs selecionadas para amostra}

\begin{tabular}{|l|c|c|c|}
\hline \multicolumn{1}{|c|}{ CRE } & $\begin{array}{c}\text { Professores } \\
\text { convocados } \\
\text { ano de 2010 }\end{array}$ & $\begin{array}{c}\text { Professores } \\
\text { convocados } \\
\text { ano de 2013 }\end{array}$ & $\begin{array}{c}\text { Professores convocados } \\
(\mathbf{2 0 1 0}+\mathbf{( 2 0 1 3 )}\end{array}$ \\
\hline CEILÂNDIA & 553 & 283 & 836 \\
\hline PLANALTINA & 234 & 174 & 408 \\
\hline RECANTO DAS EMAS & 237 & 167 & 404 \\
\hline SAMAMBAIA & 247 & 139 & 386 \\
\hline SANTA MARIA & 204 & 155 & 359 \\
\hline TOTAL GERAL & $\mathbf{1 4 7 5}$ & $\mathbf{9 1 8}$ & $\mathbf{2 3 9 3}$ \\
\hline
\end{tabular}

Fonte: Elaborado pela autora da pesquisa.

Para compreensão geográfica vide a localização no mapa do Distrito Federal das regionais definidas, observando que as setas vermelhas indicam as áreas definidas para estudo: Ceilândia, Planaltina, Recanto das Emas, Samambaia e Santa Maria. Já a seta azul aparece para efeito de localização da capital, Brasília, que corresponde ao centro administrativo do DF e caracteriza-se como referência central do sistema educacional da rede pública de ensino.

\footnotetext{
${ }^{8}$ Constitui-se na sede geral da SEDF, mas não é considerada uma CRE.
} 


\section{Quadro 12 - Localização das CREs no mapa do DF}

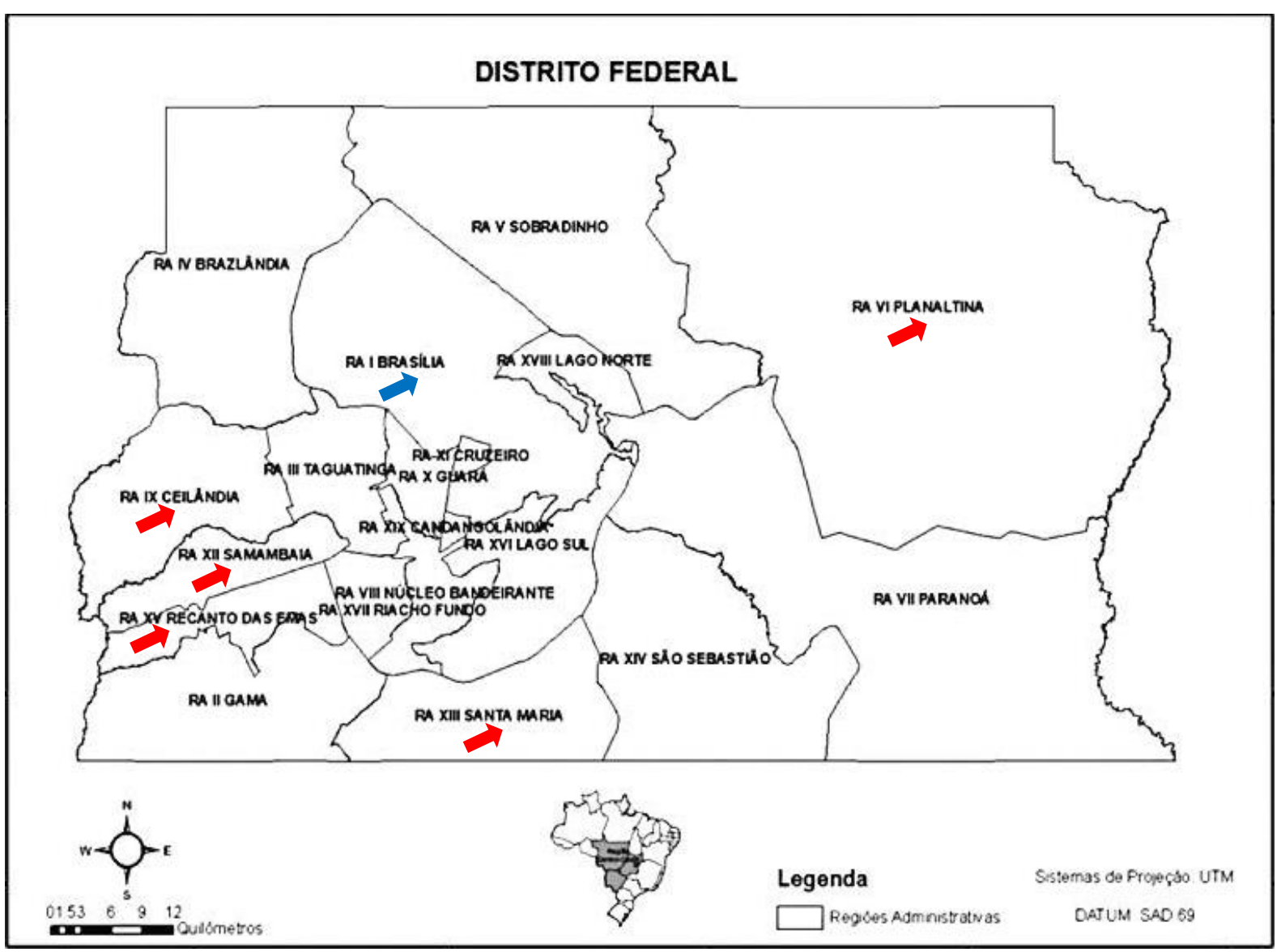

Fonte: Confeccionado pela autora da pesquisa.

Selecionadas as 05 escolas (uma em cada regional ${ }^{9}$ ) com maior número de professores recebidos no período, foram distribuídos aos professores contratados e seus respectivos gestores (diretor ou vice-diretor) questionários semiestruturados (apêndice 1 e 2 , respectivamente). Portanto, temos:

9 Não fazem divisão geográfica com a Região Administrativa (RA) I - Brasília, considerada o centro. Por serem periféricas apresentam poder aquisitivo inferior ao da população da capital, devido ao valor agregado ao terreno. 
Quadro 13 - Destinação e permanência de professores para o período

\begin{tabular}{|l|c|c|c|}
\hline \multicolumn{1}{|c|}{ CRE } & $\begin{array}{c}\text { Professores } \\
\text { destinados às } \\
\text { escolas }\end{array}$ & $\begin{array}{c}\text { Professores } \\
\text { movimentados das } \\
\text { escolas }^{11}\end{array}$ & $\begin{array}{c}\text { Professores que } \\
\text { permaneceram nas } \\
\text { escolas }^{12}\end{array}$ \\
\hline CEILÂNDIA & 51 & 23 & 28 \\
\hline PLANALTINA & 20 & 15 & 05 \\
\hline RECANTO DAS EMAS & 36 & 23 & 13 \\
\hline SAMAMBAIA & 23 & 13 & 10 \\
\hline SANTA MARIA & 26 & 06 & 20 \\
\hline \multicolumn{1}{|c|}{ TOTAL } & 156 & 85 & 76 \\
\hline
\end{tabular}

Fonte: Elaborado pela autora da pesquisa.

Observa-se que 85 (oitenta e cinco) professores, ou seja, 54,48\% deles já haviam sido movimentados em junho de 2015, quando do ato da aplicação do questionário. Contudo o universo de 76 (setenta e seis) professores ainda não se consolida na amostra, visto que alguns deles encontravam-se de licenças, atestados médicos e 01(um) professor havia sido exonerado. Assim, temos:

\section{Quadro 14 - Aplicação de questionário}

\begin{tabular}{|l|c|c|c|c|}
\hline \multicolumn{1}{|c|}{ CRE } & $\begin{array}{c}\text { Professores } \\
\text { aptos a } \\
\text { responder } \mathbf{0} \\
\text { questionário }\end{array}$ & $\begin{array}{c}\text { Professores } \\
\text { impossibilitados } \\
\text { de responder o } \\
\text { questionário }\end{array}$ & $\begin{array}{c}\text { Total de } \\
\text { questionários } \\
\text { distribuídos }\end{array}$ & $\begin{array}{c}\text { Total de } \\
\text { questionários } \\
\text { respondidos }\end{array}$ \\
\hline CEILÂNDIA & 28 & 00 & 28 & 11 \\
\hline PLANALTINA & 05 & 01 & 04 & 02 \\
\hline RECANTO DAS EMAS & 13 & 01 & 12 & 12 \\
\hline SAMAMBAIA & 10 & 00 & 10 & 03 \\
\hline SANTA MARIA & 20 & 04 & 16 & 11 \\
\hline TOTAL & 76 & 06 & 70 & 39 \\
\hline
\end{tabular}

Fonte: Elaborado pela autora da pesquisa.

A devolutiva dos questionários atingiu 55,71\%, ou seja, 39 (trinta e nove) professores responderam a pesquisa, os demais, 31 (trinta e um) professores, o

\footnotetext{
10 Professores destinados pela SEDF para as respectivas escolas (Dados fornecidos pela SEDF).

11 Professores que já não se encontravam nas respectivas escolas, remanejados para outras unidades.

12 Professores em exercício na escola quando da pesquisa de campo.
} 
correspondente a 44,28\%, não quiseram responder. No que tange aos gestores, a devolutiva foi de $100 \%$, ou seja, os 05 (cinco) gestores responderam.

É importante esclarecer que nem todos são professores iniciantes, mas também professores ingressantes, e, portanto, apresentam características distintas.

O professor ingressante

[...] já trabalha e tem experiências docentes anteriores ao seu ingresso efetivo na rede pública, entende-se que este, em termos de carreira, já vivenciou um ou mais ciclos de aprendizagem profissional e ao se vincular a uma rede, nível ou modalidade diferente e deve ser visto como ingressante diferenciando-o do iniciante (CURADO SILVA; FREITAS, 2014, p. 13).

Desse modo, nem todos os professores que responderam o questionário se constituíram em sujeitos desta pesquisa. Dos questionários obtivemos 11 professores iniciantes, mas destes somente 05 concederam entrevistas.

\section{Quadro 15 - Condição de professor iniciante}

\begin{tabular}{|l|c|c|}
\hline \multicolumn{1}{|c|}{ CRE } & $\begin{array}{c}\text { Total de questionários } \\
\text { respondidos }\end{array}$ & $\begin{array}{c}\text { Professores na condição } \\
\text { de iniciantes }\end{array}$ \\
\hline CEILÂNDIA & 11 & 3 \\
\hline PLANALTINA & 02 & 0 \\
\hline RECANTO DAS EMAS & 12 & 4 \\
\hline SAMAMBAIA & 03 & 0 \\
\hline SANTA MARIA & 11 & 4 \\
\hline \multicolumn{1}{|c|}{ TOTAL } & 39 & 11 \\
\hline
\end{tabular}

Fonte: Elaborado pela autora da pesquisa.

Como nem todos os participantes que se dispuseram a responder 0 questionário se prontificaram a conceder entrevista (segunda etapa), a condição final da amostra das entrevistas para a análise se estabeleceu da seguinte maneira:

\section{Quadro 16 - Total de entrevistados}

\begin{tabular}{|l|c|c|}
\hline \multicolumn{1}{|c|}{ CRE } & Professores entrevistados & Gestores entrevistados \\
\hline CEILÂNDIA & 1 & 1 \\
\hline PLANALTINA & 0 & 1 \\
\hline RECANTO DAS EMAS & 4 & 1 \\
\hline SAMAMBAIA & 0 & 1 \\
\hline SANTA MARIA & 1 & 1 \\
\hline \multicolumn{1}{|c|}{ TOTAL } & 6 & 5 \\
\hline
\end{tabular}

Fonte: Elaborado pela autora da pesquisa. 
Assim, para efeito de análise, utilizaram-se os 11 questionários dos professores iniciantes e as 05 entrevistas concedidas.

Embora todas as escolas atendam o Ensino Fundamental, suas condições são muito peculiares, no que tange à estrutura física, aos horários, aos níveis e tipos de atendimentos, à localização e ao público atendido, entre outras diferenças. Neste momento, nos limitaremos a caracterizá-las fazendo uso de designações específicas criadas com o objetivo de garantir o anonimato dos sujeitos e visando facilitar futuras referências ao tratarmos das escolas. Assim, temos:

- Escola A - Localizada na zona urbana, atende Ensino Fundamental (anos iniciais $-1^{\circ}$ ao $5^{\circ}$ ano) regular, nos turnos de manhã e tarde, somando 30 (trinta) turmas;

- Escola B - Localizada na zona urbana, atende Ensino Fundamental (anos iniciais e finais $-1^{\circ}$ ao $9^{\circ}$ ano) regular, no período matutino, vespertino e noturno, total de 48 (quarenta e oito) turmas;

- Escola C - Localizada na zona urbana, atende Ensino Fundamental (anos finais $-6^{\circ}$ ao $9^{\circ}$ ano) regular, em regime de educação integral, ou seja, diurno (turno único) e noturno, ao todo 21 (vinte e uma) turmas;

- Escola D - Localizada em zona urbana, atende Educação Infantil, Ensino Fundamental (anos iniciais e finais $-1^{\circ}$ ao $9^{\circ}$ ano) regular, no período matutino e vespertino, 66 (sessenta e seis) turmas;

- Escola E - Localizada em zona urbana, atende alunos do Ensino Fundamental (anos finais $-6^{\circ}$ ao $9^{\circ}$ ano) e Médio regular, em contra-turno (horário contrário ao das aulas normais) com atividades complementares, como esportes, música, dança, artes cênicas, artes plásticas e artes visuais, total de 25 (vinte e cinco) turmas; 
$\mathrm{Na}$ rede de ensino do Distrito Federal existem dois tipos de Coordenações Regionais de Ensino - CREs: as de lotação ${ }^{13}$ e as de remoção. Isso posto, vale esclarecer que professores recém-contratados só podem ser lotados nas CREs "nas quais o servidor da Carreira do Magistério Público adquire lotação, quando do seu encaminhamento na posse do cargo público e na efetivação do Procedimento de Remanejamento Externo ou permuta" (GDF, 2014, p. 2) e após transcorridos dois anos de efetivo exercício na SEDF.

Já as CREs de remoção só recebem professores movimentados por meio de concurso de remoção/remanejamento, realizado anualmente respeitando critério classificatório estabelecido por pontos na carreira. As regionais conforme esses critérios se classificam da seguinte forma:

\section{Quadro 17 - CREs de lotação e remoção}

\begin{tabular}{|c|c|}
\hline CREs DE LOTAÇÃO & CREs DE REMOÇÃO \\
\hline $\begin{array}{c}\text { Brazlândia / Ceilândia / Gama } \\
\text { Planaltina / Samambaia / Paranoá } \\
\text { Santa Maria / São Sebastião e } \\
\text { Recanto das Emas }\end{array}$ & $\begin{array}{c}\text { Plano Piloto / Guará / Núcleo Bandeirante } \\
\text { Sobradinho e Taguatinga }\end{array}$ \\
\hline 09 & 05 \\
\hline
\end{tabular}

Fonte: GDF, Portaria n 219 de 14/10/2014.

As cinco CREs selecionadas por apresentarem maior incidência de professores recém-contratados são regionais de lotação e, portanto, esses professores só podem ser movimentados para as regionais de remoção via concurso interno de remanejamento/remoção e após ter transcorrido 02 anos de efetivo exercício. Vale ressaltar que as regionais de lotação constam como sendo periféricas e que as de remoção encontram-se no centro do DF.

Para apreender a realidade concreta e histórica a que se refere o objeto da pesquisa, a coleta de dados se fundamentou em quatro fontes:

${ }^{13}$ Coordenação Regional de Ensino em que o servidor não possui lotação definitiva (GDF, 2014, p.2) 
1. Documentos legislativos sobre a educação e gestão escolar (Constituição Federal, LDBN 9.394/96, Lei 957/1995, Lei 4036/2007 e a Lei $\left.4571 / 2012^{14}\right)$;

2. Documentos oficiais produzidos pela Secretaria de Educação do Distrito Federal que trazem orientações para a rede (Regimento Escolar $/ 2009^{15}$ e Diretrizes Pedagógicas $/ 2008^{16}$ );

3. Questionários (apêndice 1 e 2) semiestruturados com perguntas discursivas e objetivas para professores iniciantes e gestores; Os questionários referentes aos professores foram os mesmos adotados pela pesquisa do GEPEFAPe e aqui utilizou-se apenas as questões que atendiam ao interesse do estudo. Já o questionário para os gestores foi criado um específico para esta pesquisa.

4. Entrevistas semiestruturadas com professores iniciantes e seus gestores;

$\mathrm{Na}$ construção das bases desta pesquisa, a revisão e análise bibliográfica contribuem apresentando o "panorama do que vem sendo realizado no que tange ao problema de pesquisa em questão, tanto em termos da reflexão teórica quanto em termos das pesquisas realizadas" (MOROZ; GIANFALDONI, 2006, p. 52). Assim, teóricos foram revistos e referenciados com suas contribuições, permitindo o entendimento do que já se consubstanciou na área agregando o devido valor científico a este trabalho.

$\mathrm{Na}$ análise documental, foram examinadas regulamentações legais inerentes ao sistema educacional do DF, considerando seu caráter norteador nas práticas pedagógicas, ações educativas e administrativas realizadas na rede de ensino.

Considerando o universo de deliberações legais, a priori temos por interesse os seguintes documentos:

\footnotetext{
${ }^{14}$ DODF 07/02/2012 - Lei de gestão democrática vigente.

${ }^{15}$ Regimento vigente até 10/02/2015 e revogado pela portaria no 15 de 11/02/2015. Por esse motivo e considerando a temporalidade da pesquisa o documento foi,então, o analisado.

${ }^{16}$ Diretriz Pedagógica que norteou as atividades durante o período estabelecido nesta pesquisa que foi até 2013.
} 
- Diretrizes pedagógicas (2009) - Documento que trata da função social da instituição educacional, dos seus fins e princípios norteadores, das propostas pedagógicas da instituição, dos fundamentos teóricos e metodológicos, da organização curricular e respectivas matrizes, da avaliação, do desenvolvimento profissional docente e do apoio educacional;

- Regimento escolar da Instituicões da rede pública de ensino do Distrito Federal (2009) - Documento que trata da organização das instituições escolares, do regime escolar, das unidades executoras, da formação complementar e intercomplementar, das instituições educacionais de atendimento socioeducativo e de disposições gerais e transitórias.

- Lei 957 de 22/11/1995 - Dispõe sobre Gestão Democrática da Escola Pública e dá outras providências;

- Lei 4.036 de 25/10/2007 - Dispõe sobre a Gestão Compartilhada nas instituições educacionais da rede pública de ensino do Distrito Federal e dá outras providências.

- Lei 4.751 de 07/02/2012 - Dispõe sobre o Sistema de Ensino e a Gestão Democrática do Sistema de Ensino Público do Distrito Federal.

- Lei 5.105 de 03/05/2013 - Reestrutura a Carreira do Magistério Público do Distrito Federal e dá outras providências.

Tais registros preconizados na forma de leis, decretos, normas, portarias e projetos se constituem em elementos fundamentais para a compreensão institucional da função de gestor e de como essa atividade está hoje assegurada, apresentando-nos suas possibilidades e limites enquanto servidor público articulador de unidade de ensino.

Para que se possam extrair informações, foram realizados dois processos de levantamento de dados: questionário e entrevista.

O questionário, constituído de questões relevantes à temática, "respondidas por escrito sem a intervenção do pesquisador" (MOROZ; GIANFALDONI, 2006, p. 
78), construído com questões discursivas e objetivas elaboradas e aplicadas pelo grupo de estudo GEPFAPe em pesquisas que tratam do professor iniciante.

Já a entrevista, "encontro interpessoal no qual é incluída a subjetividade dos protagonistas" (ALMEIDA; PRANDINI; SZYMANSKI, 2011, p. 15), proporciona informações verbalizadas e se constitui em outra forma de coletar informações em pesquisas qualitativas, tendo por finalidade ampliar as informações fornecidas pelos questionários, buscando

[...] algo que o entrevistador está querendo conhecer, utilizando um tipo de interação com quem é entrevistado, possuidor de um conhecimento, mas que irá dispô-lo de forma única, naquele momento, para aquele interlocutor. Muitas vezes, esse conhecimento nunca foi exposto numa narrativa, nunca foi tematizado (ALMEIDA; PRANDINI; SZYMANSKI, 2011, p. 14).

A entrevista permite a construção de um conhecimento ainda não sistematizado, já que a fala do entrevistado infere um caráter subjetivo, o que permite uma análise reflexiva. Essa entrevista foi estruturada a partir de um roteiro pré-estabelecido, que guia o pesquisador no seu interesse de estudo.

\begin{abstract}
A entrevista face a face é fundamentalmente uma situação de interação humana, em que estão em jogo as percepções do outro e de si, expectativas, sentimentos, preceitos e interpretações para os protagonistas: entrevistador e entrevistado. Quem entrevista tem informações e procura outras, assim como aquele que é entrevistado também processa um conjunto de conhecimentos e pré-conceitos sobre 0 entrevistador, organizando suas respostas para aquela situação. A intencionalidade do pesquisador vai além da mera busca de informações; pretende criar situação de confiabilidade para que o entrevistado se abra. Deseja instaurar credibilidade e quer que o interlocutor colabore, trazendo dados relevantes para seu trabalho. (ALMEIDA; PRANDINI; SZYMANSKI, 2011, p. 12).
\end{abstract}

Visando a facilitar a compreensão do percurso a ser realizado quanto às fontes dos dados e os seus respectivos objetivos para a pesquisa, segue sintetização: 


\section{Quadro 18 - Relação entre fontes de coleta de dados e objetivos da pesquisa}

\begin{tabular}{|c|c|}
\hline FONTES DE COLETA DE DADOS & OBJETIVOS PARA A PESQUISA \\
\hline $\begin{aligned} & \text { Documentos } \\
& \rightarrow \text { Diretrizes pedagógicas } \\
& \rightarrow \text { Regimento Escolar das instituições públicas de } \\
& \quad \text { ensino do DF } \\
& \rightarrow \text { Leis de Gestão Democrática } \\
& \quad n^{\circ} 957 \text { (22/11/1995) } \\
& \rightarrow \text { Leis de Gestão Compartilhada } \\
& n^{\circ} 4.036 \text { (25/10/2007) } \\
& \rightarrow \text { Lei de Gestão Democrática } \\
& n^{\circ} 4.751 \text { (07/02/2012) } \\
& \rightarrow \text { Lei que Reestrutura a carreira do Magistério } \\
& P u ́ b l i c o \text { e dá outras providências. } \\
& n^{\circ} 5.105 \text { (03/05/2013) }\end{aligned}$ & $\begin{aligned} \rightarrow & \text { Respaldo e embasamento para as ações do } \\
& \text { gestor; } \\
\rightarrow & \text { Convocações e nomeações de professores } \\
& \text { novos; } \\
\rightarrow & \text { Respaldo legal para ações e permanência de } \\
& \text { gestores; }\end{aligned}$ \\
\hline $\begin{array}{l}\text { Teses e Dissertações } \\
\rightarrow B D T D-I B I C T \text { e } C E D U C / F E / U n B\end{array}$ & $\rightarrow$ Estudos relacionados à temática; \\
\hline $\begin{array}{l}\text { Periódicos da Qualis } \\
\rightarrow \text { Revistas - A1 e } 2 \text { / B1 a } 5\end{array}$ & $\rightarrow$ Estudos relacionados à temática; \\
\hline $\begin{array}{l}\text { Eventos (2000 a 2014) } \\
\rightarrow \text { ENDIPE / ANPED / CONGREPRINC }\end{array}$ & $\rightarrow$ Estudos relacionados à temática; \\
\hline $\begin{array}{l}\text { Questionários e Entrevistas } \\
\rightarrow \text { Gestores escolares } \\
\rightarrow \text { Professores Iniciantes }\end{array}$ & $\rightarrow$ Sujeitos da pesquisa; \\
\hline
\end{tabular}

Fonte: Elaborado pela autora da pesquisa.

Apontadas as dimensões que originaram o interesse pelo estudo e após ser demonstrado, por meio do "estado da arte", que as discussões a respeito dessa temática estão limitadas a um trabalho, ratifica-se a necessidade do aprofundamento nesses estudos.

Considerando os objetivos propostos, o exame das prescrições legais para a gestão escolar permite-nos compreender a lógica de convívio social estabelecida para a função do gestor, mesmo que ela não seja concebida de maneira estática, tampouco linear, pois sofre influências de um movimento dialético presente nas relações estabelecidas no âmbito escolar. E compreender a atividade do gestor escolar e suas possibilidades de atuação implica percorrer um caminho histórico da constituição da função ampliando o entendimento dela mesma, de suas atividades e, consequentemente, de sua relação com o sistema educacional.

Consideradas as especificidades do sistema educacional do DF e o percurso histórico que constituiu a gestão das escolas públicas por meio de legislações 
específicas, percebe-se que as condições de gestão das escolas públicas têm sido alteradas paulatinamente. Essas alterações podem ser entendidas tanto pela perspectiva da autonomia ou da transferência de responsabilidade por parte do estado, o que poderia intensificar o trabalho do gestor.

Quanto à amostra, obteve-se um número reduzido de professores (11), visto que muitos eram ingressantes e não iniciantes. As respostas aos questionários e entrevistas se diferenciaram porque alguns professores (6) não se dispuseram a participar, totalizando 5 professores entrevistados apenas. 


\section{GESTÃO ESCOLAR E O PROFESSOR INICIANTE}

Um processo de mudança só se inicia com medidas no âmbito da prática, que levem a romper com as condições presentes.

(Paro, 2012)

Este capítulo discute a conceituação da gestão escolar e, consequentemente, aborda a figura do gestor e a legitimidade de sua função ao longo da história brasileira, bem como do DF. Debate ainda, a condição do professor iniciante, seus dilemas e realidade no contexto profissional e na SEDF.

\subsection{O gestor escolar, seu papel e a legitimação de sua atividade}

Para que possamos compreender o papel do gestor escolar, temos que nos remeter à história de sua função constituída ao longo de um grande percurso histórico, que foi se estabelecendo paralelamente à história da sociedade contemporânea e de seu conceito de educação.

Para Andreotti, Lombardi e Minto (2012, p. 11) "a administração escolar deve ser entendida como resultado de um longo processo de transformação histórica, que traz as marcas das contradições sociais e dos interesses políticos em jogo na sociedade".

Paro (2012, p. 19) complementa e reafirma esse entendimento dizendo que

A atividade administrativa não se dá no vazio, mas em condições históricas determinadas para atender a necessidade e interesses de pessoas e grupos. Da mesma forma, a educação escolar não se faz separada dos interesses e forças sociais presentes em determinada situação histórica. A administração escolar está, assim, organizada ligada à totalidade social, onde ela se realiza e exerce sua ação e onde, ao mesmo tempo, encontra as fontes de seus condicionantes.

Contribuindo com essa percepção e relacionando o conceito de Administração a uma conjuntura social historicamente situada, Sander (2007, p.12) afirma que, 
Embora a administração seja uma prática milenar, seu estudo sistemático é um fenômeno recente associado às necessidades impostas pela exploração organizacional, no bojo da consolidação da Revolução Industrial.

Partindo do pressuposto de que o conjunto social influencia as estruturas e sofrem suas influências, Marx (1989, p. 204) afirma que o sentido do trabalho irá nortear seus condicionantes, pois

[...] o que distingue as diferentes épocas econômicas não é o que se faz, mas como, com que meios de trabalho se faz. Os meios de trabalho servem para medir o desenvolvimento da força humana de trabalho e, além disso, indicam as condições sociais em que se realiza o trabalho.

Por ser uma atividade humana, a educação possui objetivos a serem alcançados, necessitando da coordenação e de esforços para obtenção do êxito. Tal condução foi sendo alicerçada paralelamente ao entendimento de sociedade e às necessidades humanas e suas relações no âmbito político, econômico, social e cultural.

Refletir sobre esse sentido etimológico da administração no campo educacional remete-nos aos seus objetivos, seus agentes, sua estrutura e outros tantos elementos que a constituem. A administração,

[...] em sua concepção mais simples e abstrata, isto é, como utilização racional de recursos para a realização de fins, não apresenta nada que seja incompatível com o progresso do homem, tanto em sua dimensão individual quanto social [...] a atividade administrativa é não apenas exclusiva do homem, mas também necessária a sua vida, já que, por um lado, só ele é capaz de estabelecer objetivos e, por outro, sua própria especificidade humana depende da capacidade que tem de transcender sua situação natural, buscando realizar por meio da ação racional, os objetivos a que se propõe. Dessa forma, o que determina o caráter conservador ou transformador da administração é a natureza dos objetivos que ela busca concretizar, os quais - em conjunto e como resultante das forças sociais predominantes em um determinado momento histórico (PARO, 2012, p.206).

Contribuir para o alcance desses objetivos constitui-se a função de um gestor escolar, fortalecendo o processo democrático e favorecendo a reflexão coletiva. Considerado por muitos como peça chave de uma constituição diretiva, responsável pela escola, tendo que articular seus vários segmentos e interesses, o gestor escolar assume 
[...] posição bastante contraditória, já que tem de exercer duas ordens de funções, em princípio, inconciliáveis: como educador, ele precisa cuidar da busca dos objetivos educacionais da escola; como gerente responsável último pela instituição escolar, tem de fazer cumprir as determinações emanadas dos órgãos superiores dos sistemas de ensino que, em grande parte, acabam por concorrer para a frustração de tais objetivos (PARO, 2012, p. 174).

Diante dessa tarefa, sua função social torna-se complexa e, em meio a um universo contraditório, dinâmico e historicamente situado, modifica-se e é modificada ao longo do tempo. Em uma relação mútua entre a educação e a sociedade, seus espaços e agentes também estão submetidos a essa ligação e, por consequência, aliados a um conjunto social. Dessa forma, há que se compreender como esse conjunto se construiu ao longo da história, ou seja, como ocorreram suas transformações, analisando seus impactos sobre o contexto educacional, especialmente no Brasil.

Em nosso país, a história da administração escolar começa basicamente junto com a história da educação brasileira, mas no "período colonial, a educação tinha pouca importância para os colonizadores e para a população em geral e, consequentemente, não se prestou suficiente atenção à administração" (SANDER, 2007, p. 20).

Nos primórdios do período colonial, a administração das colônias se dava dividindo as incumbências conforme os assuntos tratados. E, na esfera da administração civil, havia a Igreja que, atrelada a interesses colonizadores, implantou as primeiras escolas brasileiras, logo passadas ao controle dos jesuítas, cujos interesses ideológicos visavam promover

[...] a expansão da fé e do império, reunindo mercadores e evangelizadores [...] com sua política de instrução - uma escola, uma igreja -, edificaram templos e colégios nas mais diversas regiões da colônia, construindo um sistema de educação e difundindo sua pedagogia (ANDREOTTI; LOMBARDI; MINTO, 2012, p. 33).

Para coordenar toda essa estrutura, os jesuítas elaboraram um documento chamado de Ratio Studiorum, ou seja, um estatuto pedagógico "composto de um conjunto de regras, que envolvia desde a organização, administração escolar e a pedagogia até a observância estrita da doutrina católica" (ANDREOTTI; LOMBARDI; MINTO, 2012, p. 34). Ordenados em estrutura hierarquicamente estabelecida nas 
igrejas e com controle de todos os processos que envolviam seus interesses, os jesuítas acabaram por articular uma forma própria de controle, perfazendo uma ideia de "rede" que se consolidou como um gerenciamento, articulação e controle de todas as instituições vinculadas. Sem ponderar aqui, as questões referentes aos métodos, o fato é que a administração dos jesuítas mostrou-se eficiente na busca de seus ideais (ANDREOTTI; LOMBARDI; MINTO, 2012). Assim, iniciou-se uma trajetória educacional no Brasil edificada em meio a disputas ideológicas vinculadas às principais transformações políticas e econômicas do país.

Com o advento das reformas pombalinas ${ }^{17}$, surgiram no Brasil as primeiras escolas públicas e seus processos de organização. Contudo foi em 1847 a partir da Lei no 29 de 16 de março na Província de São Paulo que se criou o primeiro cargo de directhor do licêo. Esse diretor ficaria responsável pela gestão dos liceus ${ }^{18}$ (escolas secundárias) e pela oferta educacional da província e deveria ser inteligente, patriota e com reconhecida probidade, conforme estabelecia o documento que concedia-lhe a função de:

Tomar conta do liceu, inspecionar a conduta dos professores, remeter ao presidente da província, sugerir alterações para mudanças, tanto na rotina do colégio como na vida profissional de seus professores. Além disso, deveria encaminhar anualmente um relatório contendo: o estado moral e intelectual do liceu; um mapa dos alunos frequentes, declarasse os aprovados, os reprovados e os que não fizeram os exames, e especificasse os considerados incorrigíveis; atestar a frequência dos empregados; discutir em conselho, com os professores, os problemas do liceu; repreender os alunos; designar as horas das aulas; despachar os requerimentos a ele destinados; marcar e presidir a banca de exames dos alunos, escolhendo os examinadores; conceder, quando necessário, licença aos professores e aos porteiros; e por fim, intermediar a correspondência entre os professores e o presidente da província (ANDREOTTI; LOMBARDI; MINTO, 2012, p. 59$60)$.

No entanto, caminhando um pouco mais na história, modificações foram ocorrendo e, já na década de 1920, motivados por um ideário de seus líderes ${ }^{19}$

\footnotetext{
17 Nome dado às mudanças de caráter administrativo, econômico e educacional realizadas pelo Marquês de Pombal (1769), Ministro de D. José I (ANDREOTTI; LOMBARDI; MINTO, 2012)

18 Ver (ANDREOTTI; LOMBARDI; MINTO, 2012, p. 53-62)

${ }^{19}$ Lourenço Filho (1923), no Ceará; Lysímaco da Costa (1924), no Paraná; Anísio Teixeira (1925), na Bahia; José Augusto (1925), no Rio Grande do Norte; Francisco Campos e Mário Casassanta 1927), em Minas Gerais e Carneiro Leão (1928), em Pernambuco (ANDREOTTI; LOMBARDI; MINTO, 2012, p. 77).
} 
educacionais à época, sucederam-se reformas no sistema educativo do país que viriam a refletir em estruturas até então consolidadas. No Brasil, para Filho e Vidal (2000, p. 20),

[...] o espaço e o tempo escolares foram sendo produzidos diferenciadamente ao longo da nossa história da educação e se constituíram em dois grandes desafios enfrentados para se criar, no Brasil, um sistema de ensino primário ou elementar que viesse atender, minimamente que fosse, às necessidades impostas pelo desenvolvimento social e/ou às reivindicações da população.

Impulsionado por interesses políticos/ideológicos, o governo priorizou a organização do ensino primário, iniciando-a em "São Paulo e depois, em vários estados brasileiros, para assumir a forma mais acabada da proposta dos grupos escolares" (FILHO; VIDAL, 2000, p. 24), que seriam

[...] concebidos e construídos como verdadeiros templos do saber (Souza, 1998) encarnavam, simultaneamente, todo um conjunto de saberes, de projetos políticos-educativos, e punham em circulação o modelo definitivo da educação do século XIX: o das escolas seriadas. [...] Monumentais, os grupos escolares, na sua maioria, eram construídos a partir de plantas-tipo em função do número de alunos, em geral 4,8 ou 10 classes, em um ou dois pavimentos, com nichos previstos para biblioteca escolar, museu escolar, sala de professores e administração. Edificadas simetricamente em torno de um pátio central ofereciam espaços distintos para o ensino de meninas e meninos (FILHO; VIDAL, 2000, p. 25).

Muito próximo do que são as escolas atuais, constituía-se não só uma estrutura física típica, mas também procedimentos didático-pedagógicos, condutas muito peculiares e, também, uma nova cultura escolar. Estabelecia-se, então, uma nova ordem educacional no país.

As reformas expressavam o princípio de que "educar era, então, a pedra de toque desse novo regime que se instalava" e, por consequência, surgia também, a preocupação com a administração das escolas, no sentido de "racionalizá-las e torná-las mais organizadas e eficientes" (ANDREOTTI; LOMBARDI; MINTO, 2012, p. 75).

Com esse pensamento, institui-se nas escolas primárias a figura do professordiretor que, nomeado, tinha por objetivo coordenar e administrar a instituição, recebendo esse nome por se entender que tal função - a de diretor - necessitaria de alguém com experiência docente, ou seja, primeiramente deveria ser professor. 
Nas escolas primárias, os professores eram os responsáveis por sua administração, embora não recebessem a titulação de diretor, como já ocorria nos liceus. Inicialmente, algumas escolas tinham por critério de gênero serem destinadas especificamente às meninas $e$, portanto, ficavam sob a responsabilidade de mulheres alfabetizar e administrar, contudo elas não eram tidas como capacitadas para exercerem sozinhas as atividades administrativas da escola. (ANDREOTTI; LOMBARDI; MINTO, 2012).

Seus administradores, professores diplomados, escolhidos e nomeados pelo governo para o cargo de diretor,

[...] continuavam a reger uma classe, auxiliado pelo adjunto. A docência, porém, começou a se tornar um entrave à boa execução das atividades administrativas, pedagógicas e de fiscalização. O acúmulo dessas funções explicita a necessidade de um auxiliar que ajudasse o diretor no desempenho dos serviços educacionais da instituição (ANDREOTTI; LOMBARDI; MINTO, 2012, p. 88).

Visto como autoridade do governo, o diretor logo passou a acumular demandas administrativas e pedagógicas que o obrigaram a ter um ajudante. Surgiu, então, a figura do vice-diretor, subordinado diretamente ao seu superior imediato, o diretor, que, por sua vez, estava sujeito ao controle externo aos seus interesses, digo, o governo.

Entretanto esse poder foi sendo destituído paralelamente às mudanças, e novas funções foram criadas na medida em que as escolas e os interesses presentes ampliaram-se e modificaram-se. Com a reforma paulista, criaram-se as delegacias regionais que tinham por finalidade coordenar, planejar e fiscalizar o andamento das escolas, visando a uma melhor racionalização das atividades de administração do ensino público.

O poder dado ao Diretor do grupo escolar, que além da administração da sua escola, adquiriu um status de destaque na comunidade local nos primeiros anos da República, era gradativamente diminuído pela fiscalização - muitas vezes por meio de visitas periódicas - que o governo passava a realizar nas escolas. O papel central, antes assumido pelo Diretor do grupo escolar, era agora transmitido aos Delegados Regionais e aos Inspetores de distritos (ANDREOTTI; LOMBARDI; MINTO, 2012, p. 99). 
Caminhando para uma fase desenvolvimentista com 0 advento da industrialização e urbanização, intensificaram-se as necessidades sociais no país e, com elas, a demanda de mão-de-obra especializada para atender o processo de desenvolvimento nacional. No Brasil, criou-se um clima de reconstrução e muitas mudanças no campo educacional também puderam ser observadas, como criação de ministério para tratar de assuntos educacionais, elaboração de plano nacional de educação, estabelecimento da gratuidade do ensino, além de outras reformas no campo educacional que traziam definições para a União e para os Estados. Desde a implementação de regime universitário para a educação superior, a organização do ensino secundário e a criação de ensino profissionalizante. Até os exames de admissão na transição entre o ensino fundamental e médio, foram se estabelecendo modificações que, "de certo modo", iam democratizando o ensino, embora estivesse longe do ideal.

Essas mudanças ampliaram alguns constructos educativos, mas estavam carregadas de ideologias nacionalistas e patrióticas e difundiam as políticas pedagógicas de interesse do governo. Assim, as ações educacionais passaram, mais uma vez, pelos interesses do Estado republicano.

Com o surgimento do movimento "Escola Nova" e o "Manifesto dos Pioneiros", na década de 1930, ocorreram mudanças no campo educacional, entre elas, o nascimento do curso de especialização para Administradores Escolares com dois anos de duração (ANDREOTTI; LOMBARDI; MINTO, 2012).

Em meio a esse cenário e em virtude da obrigatoriedade do concurso para professores do magistério, criou-se o Instituto de Educação que, absorvido pela recém-criada Universidade de São Paulo, passou a contar com um curso específico para Administradores Escolares, atendendo a uma necessidade de qualificar os diretores já atuantes em escolas do Estado, iniciativas que "demonstravam a preocupação em qualificar mais especificamente os profissionais de educação para ocuparem cargos de administração" (ANDREOTTI; LOMBARDI; MINTO, 2012, p. 116).

Em meio à abertura para o capital estrangeiro, guerra fria e divisões entre bloco socialista e bloco capitalista, na década de 1960, a educação passou a ser 
vista como "fator de desenvolvimento econômico, como instrumento de progresso técnico e como meio de seleção e ascensão social" (SANDER, 2007, p. 46). Assim, no

[...] campo da educação e sua administração, o enfoque desenvolvimentista inseriu-se no poderoso movimento internacional da economia da educação e suas áreas correlatas, como a formação de recursos humanos para o desenvolvimento, as teorias do capital humano e do investimento no ser humano e suas taxas de retorno individual e social (SANDER, 2007, p. 45).

Partindo para uma fase de hegemonia internacional (SANDER, 2007), a educação foi influenciada por uma visão utilitarista de produção de mão-de-obra para o mercado da industrialização. Contudo, devido à intensa agitação política e interesses ideológicos diferenciados, logo veio o golpe militar $^{20}$ no ano de 1964.

No entanto, na década de 1970, o Brasil enfrentou uma grande crise econômica e perdeu o dinamismo e entusiasmo de outrora e "o sistema educacional deixou de ser concebido como alavanca e motor de transformação e o otimismo pedagógico, que concebia a educação e o professor como fontes de progresso, transformou-se em pessimismo e desilusão" (SANDER, 2007, p.48).

Ao ser estabelecida a ditadura militar que perdurou de 1964 a 1984, a década de 1980 moveu-se por pressões pela democratização, em que se fortaleceram movimentos sociais a favor de eleições diretas para os cargos públicos, principalmente para o cargo da Presidência da República, conquistada nas "Diretas Já!"21.

Com a redemocratização do país, as conquistas democráticas no âmbito político começaram a refletir no campo educacional. Nos períodos que se seguiram, por exemplo, surgiu o movimento de democratização da educação, com o lema de democratização dos processos de gestão, prezando pela descentralização administrativa e pedagógica, pela gestão participativa, pelas eleições diretas para dirigentes escolares, entre outras.

As lutas e embates nessa perspectiva se aguçaram e, em meio a mudanças, o termo gestão democrática foi inserido na Lei de Diretrizes e Bases da Educação Nacional (LDBN 9396/1996), em seu artigo 30 inciso VIII, assegurando, como um dos princípios e fins da educação nacional, a "gestão democrática do ensino público,

\footnotetext{
${ }^{20}$ Ver capítulo 7 Andreotti (2012).

${ }^{21}$ Movimento nacional pela redemocratização do país.
} 
na forma desta Lei e da legislação dos sistemas de ensino". Tal gestão deve, então, preocupar-se com a participação da comunidade escolar (professores, funcionários, alunos e pais ou membros da comunidade) na administração da escola.

Percebe-se que muito ocorreu até que chegássemos ao contexto educacional atual. $E$ as mudanças não aconteceram nem de forma pacífica e nem consensual, tampouco resultaram na melhor organização já estabelecida ou almejada por muitos. Percorrendo um caminho de muitas lutas, o atual sistema educacional brasileiro foi se consolidando e juntamente com ele a condição do gestor escolar.

\subsubsection{Gestor ou administrador? Uma terminologia em discussão}

As organizações escolares sofrem influências sociais, portanto princípios e métodos aplicáveis à administração geral acabam por influenciar as experiências administrativas em âmbito escolar. Conforme vão se estabelecendo os debates e definições no campo da administração, enquanto área de conhecimento, conceitos e procedimentos vão sedimentando-se ou modificando-se e passam a ser assimilados pelas instituições escolares.

Em razão de diferentes etapas de produção capitalista estabelecida ao longo da história, as interações no campo social e do trabalho foram afetadas e seus processos administrativos alterados visando ampliar lucro e produtividade. Os modelos taylorista/fordista ${ }^{22}$ de administração, já não mais atendendo aos interesses do capital, entram em crise e elaboram-se novas formas de gestão correspondentes a essas novas demandas.

Esses movimentos de mudanças nas relações administrativas do mercado produtivo refletem consideravelmente nos sistemas de gestão e organização escolar. Por imposição de nova lógica de mercado, demandam um novo perfil de cidadão, de consumidor e de trabalhador, atingindo, assim, a organização escolar.

${ }^{22}$ Expressão dominante do sistema produtivo e de seu respectivo processo de trabalho que vigorou na grande indústria, ao longo praticamente de todo o século $X X$, sobretudo a partir da primeira década, baseava-se na produção em massa de mercadorias, que se estruturava a partir de uma produção homogeneizada e enormemente verticalizada [...] racionalizava ao máximo as operações realizadas pelos trabalhadores, combatendo o "desperdício" na produção, reduzindo o tempo e aumentando o ritmo de trabalho (ANTUNES, 1999, p.36-37). 
Resistente às imposições ideológicas predominantes no bojo social e apropriando-se de um contexto de redemocratização política e administrativa estabelecida na sociedade brasileira, o campo educacional passa a discutir sobre os aspectos organizacionais que lhe pertencem tentando superar a visão tecnicista de educação através da atribuição de um caráter humanizador aos seus processos administrativos constituídos numa perspectiva de transformação social.

Ainda há muitas discussões em relação à aplicação do termo "gestão" ao contexto educacional brasileiro, intensificando os debates e questionando o uso das terminologias e suas consequências no ambiente escolar. Assim, surge uma questão: gestor ou administrador? Seria apenas uma discussão terminológica? Que conceitos esses termos carregariam?

Durante muito tempo, o gestor escolar foi designado como diretor e, em muitos casos, ainda o é. Contudo, em meados dos anos 1990, as discussões conceituais sobre o termo "administração escolar" e "gestão escolar" se intensificaram, por vezes causada pela confusa aplicação que se pode dar à palavra direção "utilizada indistintamente como sinônimo de chefia, comando, gestão, governo, administração, coordenação, supervisão, superintendência” (PARO, 2015, p.37).

[...] Na maioria dos sistemas de ensino, quando se fala em administrador escolar, pensa-se logo na figura do diretor de escola, embora haja exceções, em que existe a figura do diretor e a do administrador, com funções distintas. Também na literatura sobre administração escolar, é generalizado (embora não exclusivo) o uso indistinto de administrador (ou gestor) escolar e de diretor escolar com o mesmo significado. Entretanto, parece ser quase unânime a preferência pela expressão "diretor escolar", quando se trata de denominar oficialmente, por meio de leis, estatutos ou regimentos, aquele que ocupa o cargo hierarquicamente mais elevado no interior de uma unidade de ensino. Mesmo entre a população usuária, quando alguém se refere ao cargo, é ao de diretor que se reporta, não ao de administrador, mas sim do diretor escolar.

Desse modo, ponderando o termo administração escolar, Paro (2012, p. 32) infere que, tanto na visão da prática quanto na teoria, a administração se divide em "dois campos que se interpenetram: a racionalização do trabalho e a coordenação", que com relação entre si, dependem do esforço humano.

Ao incorporar a esses conceitos as funções de planejamento, organização, direção e controle, Libâneo (2007, p.316) sustenta que o processo "de chegar a uma 
decisão e de fazer a decisão funcionar caracterizam a ação designada como gestão". Com isso, gestão seria "a atividade pela qual são mobilizados meios e procedimentos para atingir os objetivos da organização, envolvendo, basicamente, os aspectos gerenciais e técnico-administrativos".

As duas terminologias "Gestor" e "Diretor" são comumente encontradas em boa parte das produções acadêmicas e, do mesmo modo, sendo utilizadas nas instâncias educacionais, mas existe um debate conceitual a respeito da ideia que cada vocabulário traz consigo, originando divergências sobre o assunto.E, embora haja tais discordâncias, apresentar a discussão torna-se importante, considerando que ideologias podem estar presentes por trás de aparentes mudanças terminológicas.

Partindo de uma conceituação geral, simples, sem os determinantes sociais, ou modo de produção vigente, ambos os termos tem sua origem no latim. $\mathrm{O}$ termo Administrare refere-se ao "ato de gerir, de governar, de dirigir negócios públicos ou privados" (ANDREOTTI; LOMBARDI; MINTO, 2012, p. 23), apresentando caráter distanciador entre o executor e o resultado da ação. Já a palavra gestão derivada de gerere "significa gerir um bem, defendendo os interesses daquele que o possui constituindo-se em uma aplicação do gerir" (SILVA, 2007, p. 22) que significaria levar sobre si, chamar para si, portanto, conferindo um caráter de maior pertencimento na ação.

As concepções educativas que se estabelecem no contexto escolar acabam por alterar as relações entre os sujeitos e dos sujeitos com as atividades desempenhadas. Assim, apresentando características muito peculiares, as principais concepções de organização e gestão escolar foram sintetizadas por Libâneo (2001, p. 327) e podem nos ajudar nessa discussão. Vejamos: 


\section{Quadro 19 - Concepções de organização e gestão escolar}

\begin{tabular}{|c|c|c|c|}
\hline TÉCNICO-CIENTÍFICA & AUTOGESTIONÁRIA & INTERPRETATIVA & $\begin{array}{l}\text { DEMOCRÁTICO- } \\
\text { PARTICIPATIVA }\end{array}$ \\
\hline $\begin{array}{l}\text {-Prescrição detalhada de } \\
\text { funções e tarefas, } \\
\text { acentuando a divisão } \\
\text { técnica do trabalho } \\
\text { escolar; } \\
\text {-Poder centralizado no } \\
\text { diretor, destacando-se } \\
\text { as relações de } \\
\text { subordinação, em que } \\
\text { uns têm mais autoridade } \\
\text { do que outros; } \\
\text {-Ênfase na administração } \\
\text { reguladora (rígido } \\
\text { sistema de normas, } \\
\text { regras, procedimentos } \\
\text { burocráticos de controle } \\
\text { das atividades), } \\
\text { descuidando-se, às } \\
\text { vezes, dos objetivos } \\
\text { específicos da instituição } \\
\text { escolar. } \\
\text {-Comunicação linear (de } \\
\text { cima pra baixo), } \\
\text { baseada em normas e } \\
\text { regras. } \\
\text {-Mais ênfase nas tarefas } \\
\text { do que nas pessoas. }\end{array}$ & $\begin{array}{l}\text {-Vínculo das formas de } \\
\text { gestão interna com as } \\
\text { formas de autogestão } \\
\text { social (poder coletivo na } \\
\text { escola para preparar } \\
\text { formas de autogestão no } \\
\text { plano político); } \\
\text {-Decisões coletivas } \\
\text { (assembleia, reuniões), } \\
\text { eliminação de todas as } \\
\text { formas de exercício de } \\
\text { autoridade e de poder. } \\
\text {-Ênfase na auto- } \\
\text { organização do grupo de } \\
\text { pessoas da instituição, } \\
\text { por meio de eleições e } \\
\text { de alternância no } \\
\text { exercício de funções; } \\
\text {-Recusa a normas e a } \\
\text { sistemas de controles, } \\
\text { acentuando a } \\
\text { responsabilidade } \\
\text { coletiva; } \\
\text {-Crença no poder } \\
\text { instituinte da instituição e } \\
\text { recusa de todo poder } \\
\text { instituído. O caráter } \\
\text { instituinte dá-se pela } \\
\text { prática da participação e } \\
\text { da autogestão, modos } \\
\text { pelos quais se contesta } \\
\text { o poder instituído; } \\
\text {-Ênnase nas inter- } \\
\text { relações, mais do que } \\
\text { nas tarefas. }\end{array}$ & $\begin{array}{l}\text {-A escola é uma } \\
\text { realidade social } \\
\text { subjetivamente } \\
\text { construída, não dada } \\
\text { nem objetiva; } \\
\text {-Privilegia menos o ato } \\
\text { de organizar e mais a } \\
\text { "ação organizadora", } \\
\text { com valores e práticas } \\
\text { compartilhados; } \\
\text {-A ação organizadora } \\
\text { valoriza muito as } \\
\text { interpretações, os } \\
\text { valores, as percepções e } \\
\text { os significados } \\
\text { subjetivos, destacando o } \\
\text { caráter humano e } \\
\text { preterindo o caráter } \\
\text { formal, estrutural, } \\
\text { normativo. }\end{array}$ & $\begin{array}{l}\text {-Definição explícita, por } \\
\text { parte da equipe escolar, } \\
\text { de objetivos } \\
\text { sociopolíticos da escola; } \\
\text {-Articulação da atividade } \\
\text { de direção com a } \\
\text { iniciativa e a participação } \\
\text { das pessoas da escola e } \\
\text { das que se relacionam } \\
\text { com ela; } \\
\text {-Qualificação e } \\
\text { competência } \\
\text { profissional; } \\
\text {-Busca de objetividade no } \\
\text { trato das questões da } \\
\text { organização e da } \\
\text { gestão, mediante coleta } \\
\text { de informações reais. } \\
\text { •Acompanhamento e } \\
\text { avaliação sistemáticos } \\
\text { com finalidade } \\
\text { pedagógica: diagnóstico, } \\
\text { acompanhamento dos } \\
\text { trabalhos, reorientação } \\
\text { de rumos e ações, } \\
\text { tomada de decisões; } \\
\text { - Todos dirigem e são } \\
\text { dirigidos, todos avaliam } \\
\text { e são avaliados; } \\
\text { •Ênfase tanto nas tarefas } \\
\text { quanto nas relações. }\end{array}$ \\
\hline
\end{tabular}

Fonte: Libâneo (2001, p. 327).

Portanto, administração ou gestão assumem consequentemente diferentes significados conforme a concepção que se tenha dos objetivos da educação em relação à sociedade. Os processos intencionais e sistemáticos de se chegar a uma decisão, de fazer funcionar, caracterizam a ação denominada gestão, o que torna a direção um atributo da gestão (LIBÂNEO, 2004, p.101). A direção seria, assim, colocada como algo que materializa a tomada de decisão.

Em leis que definem diretrizes e regulamentam o sistema educacional, como a Constituição Federal (1988) e a LDBN 9.394 (1996), a função de gestão não 
carrega consigo a mesma perspectiva de termo. Vejamos no caso da Lei 4.751/2012 que dispõe sobre a gestão democrática no sistema público de ensino do DF:

[...] Art. $2^{\circ}$ A gestão democrática da Rede Pública de Ensino do Distrito Federal, cuja finalidade é garantir... observará os seguintes princípios:

I - participação da comunidade escolar... e na eleição de diretor e vicediretor da unidade escolar;

Assim, o termo "gestão" estaria sendo empregado na perspectiva sistêmica, ou macro. Já a função no contexto escolar, não acompanha a terminologia, o que na lógica resultante derivaria no termo "gestor", muito embora estejam concomitantemente empregadas na mesma Lei.

Importa-nos lembrar também que a intencionalidade da ação do gestor ou diretor não depende necessariamente do vocabulário utilizado, mas da visão educativa do profissional e da sua relação com os fins a que se destina a escola, considerando as múltiplas determinações às quais foi submetido durante o seu processo de formação como sujeito e profissional, visto que

[...] mudança organizacional nenhuma se introduz como se fosse um corpo estranho que viesse desalojar as condições anteriores e ocupar plenamente o seu lugar. Por mais convencidos que estejamos da necessidade de transformação no sentido da democratização das relações no interior da escola, é preciso estar consciente de que elas devem partir das condições concretas em que se encontra a Administração Escolar hoje. (PARO, 2012, p.215).

Neste trabalho, o termo gestor foi adotado em virtude de sua derivação da palavra gestão que agrega uma perspectiva democrático/participativa aos processos decisórios das instituições, compartilhando ações e resultados, dando ênfase tanto nas tarefas, quanto nas relações, rompendo com visões hierarquizadas e unilaterais nos processos administrativos. Embora a escola não esteja fora de um contexto social capitalista e, portanto, sofrendo influências de ideologias e valores arraigados na sociedade, o seu sentido está em justamente superar esses valores por meio de uma transformação social que conteste as ideologias e hegemonias dominantes, por meio da democratização da educação, seus constructos e conhecimentos. 


\subsubsection{A natureza constitutiva do gestor escolar no Distrito Federal}

No Distrito Federal, a história da educação e de seu sistema de ensino foi se constituindo paralelamente à história da educação nacional e suas respectivas influências, mas carregando em sua origem a responsabilidade de se tornar modelo para o resto do país. Alicerçada nos ideais de Anísio Teixeira, a educação no DF teve sua elaboração estabelecida de maneira peculiar, desde a estrutura física pautada em uma concepção integral e integradora, em que a escola deveria incorporar "funções anteriormente assumidas por outras agências educativas, como a família e o meio social" (PEREIRA, 2011, p.51), até a disponibilização de recursos exclusivos para a execução do projeto. Não se pode negar que a transferência da capital para o centro do país, a construção de uma nova cidade, Brasília, influenciou no contexto ímpar da história educacional nessa região.

Na ocasião, final da década de 1950 e início dos anos 1960, em meio à política nacional-desenvolvimentista implementada pelo governo de Juscelino Kubitschek, o ideário era de

[...] estruturar um sistema de educação, único, democrático, acessível a todos, independentemente da classe social, centrado no indivíduo e no desenvolvimento de suas potencialidades e sem a velha dicotomia entre formação geral e formação especial, entre formação para o trabalho e formação para o lazer, enfim, entre o útil e o ornamental, que tem caracterizado a educação brasileira ao longo do tempo (PEREIRA, 2011, p. 35).

Logo, Anísio Teixeira iniciou seu projeto e, em outubro de 1957, com a presença do então Presidente da República Juscelino Kubitschek inaugurou-se a primeira escola de Brasília, chamada de Escola Júlia Kubitschek ${ }^{23}$, que, na ocasião, teve seu grupo docente composto, por professoras selecionadas entre "esposas e filhas de funcionários, portadoras de diploma de normalista expedido por escola oficial" (PEREIRA, 2011, p. 149). A condição da gestão da primeira escola, que não teve uma designação de um gestor, nem tampouco de critérios para sua seleção, conforme descrito Pereira (2011, p. 151), ocorreu da seguinte forma:

[...] As dificuldades que o grupo de professoras pioneiras teve de enfrentar no início do funcionamento da escola - já que nada havia ainda sido

${ }^{23}$ Mais informações, ver (PEREIRA, 2011, p.146). 
estabelecido para o desenvolvimento das atividades docentes e a ação pedagógica dependia de suas iniciativas e da busca de soluções criativas conduziram à adoção de práticas democráticas de gestão e de trabalho compartilhado. Assim, durante os primeiros meses de funcionamento, a escola não teve diretora designada. Em razão do acúmulo de trabalho e tendo em vista não sobrecarregar uma só pessoa para organizar as atividades demandadas para a estruturação da escola, especialmente nas condições precárias do meio em que essa se inseria, a função de diretora, por decisão do grupo de docentes pioneiras, foi exercida por todas as professoras, em sistema de rodízio, durante vinte dias, sendo as tarefas administrativas e pedagógicas definidas e realizadas coletivamente, mediante trabalho compartilhado. Após essa experiência de gestão, o grupo docente elegeu, por voto direto, uma das colegas, a professora Santa Soyer, que veio a ser a primeira diretora da instituição.

O relato mostra uma concepção de gestão que, embora tenha permitido a participação rodiziada entre os vários membros da escola na condução das tarefas, não perdurou assim, pois logo foi deliberada, de maneira democrática e coletiva, uma professora responsável para assumir a função.

Em 1988, a Constituição Federal estabeleceu no artigo 206, princípios nos quais o ensino público brasileiro devia ser ministrado, afirmando no inciso VI que a gestão devia se dar de maneira democrática e participativa.

Em 1996, com a Lei de Diretrizes e Bases para a Educação Nacional - LDBN 9.394/96 - que tem por objetivo regulamentar a educação nacional e fazer os devidos ajustamentos para a aplicação de tais princípios constitucionais, foi reafirmado no artigo $3^{\circ}$, inciso VIII, que a gestão do ensino público deve ser democrática, respeitando a forma da lei e da legislação dos sistemas de ensino. Mais adiante, no artigo 14, permitiu-se aos sistemas públicos de ensino definir as normas da gestão democrática na educação básica.

Reflexo de uma mudança na própria sociedade, iniciada na década de 1980, a democratização da escola pública, busca a partilha do poder entre seus dirigentes e tenta estabelecer a participação de todos na tomada de decisões, considerando-se de várias instâncias participativas, que Paro (2011, p.15), classifica em três grupos:

[...] Mecanismos coletivos de participação (conselhos de escola, associações de pais e mestres, grêmio estudantil, conselho de classe); as relativas à escolha democrática dos dirigentes escolares; e as que dizem respeito a iniciativas que estimulem e facilitem, por outras vias, o maior desenvolvimento de alunos, professores e pais nas atividades escolares. 
Como a LDBN 9.394/96 oportuniza a escolha dos critérios democráticos conforme cada sistema e suas peculiaridades, os Estados e Munícipios a fazem em consonância à sua realidade.

Assim, no Distrito Federal, alguns de seus reflexos foram percebidos, visto que, no ano letivo de 1996, as escolas já contavam com: 1) Conselhos Escolares ${ }^{24}$; e 2) Dirigentes escolares eleitos pela maioria de voto direto da comunidade. Mudanças amparadas na Lei $n^{\circ} 957$ de novembro de 1995, que dispunha sobre a Gestão Democrática da Escola Pública, asseguraram que a gestão da unidade de ensino seria exercida pela Direção e pelo Conselho Escolar eleitos no artigo $2^{\circ}$, retirando das mãos do executivo e passando para instância local o poder de deliberar conforme os interesses coletivos, pautando-se nos princípios de:

I. Livre organização dos segmentos da comunidade escolar em nível de unidade de ensino, no âmbito do Distrito Federal;

II. Participação de todos os segmentos das unidades de ensino nos processos e instâncias decisórios, desde que se garanta, nas bases, sua representação democrática e organizada, na forma desta Lei;

III. Escolha dos diretores das unidades de ensino, com a participação direta da comunidade, de acordo com o estabelecido nesta Lei;

IV. Autonomia das unidades de ensino, no que Ihes couber pela legislação vigente, na gestão pedagógica, administrativa e financeira de seu projeto educativo, sob responsabilidade de um Conselho Deliberativo Escolar, com representação eleita dos quatro segmentos da comunidade escolar: alunos, pais ou responsáveis, professores/especialistas e servidores da carreira de assistência à educação, com presença nata do diretor eleito;

v. Organização normativa do sistema, de forma democrática, por meio de um Conselho de caráter consultivo e deliberativo;

VI. Participação do Conselho de Educação do Distrito Federal e dos Conselhos Escolares na elaboração do orçamento, considerando o elenco de necessidades e prioridades;

VII. Repasse para a Secretaria de Educação, de quinze em quinze dias, dos recursos orçados e dos impostos e transferências arrecadados no período, para manutenção do desenvolvimento do ensino;

VIII. Transparência nos mecanismos administrativos e financeiros, em todas as instâncias;

${ }^{24}$ Conselho deliberativo máximo da escola, composto por no mínimo 5 (cinco) e, no máximo, 17 (dezessete) membros dos segmentos que integram a comunidade escolar. Tem por obrigatoriedade ser composto paritariamente (50\% para pais ou responsáveis por alunos e $50 \%$ para professores/especialistas e servidores da carreira de assistência à educação) (GDF, 1995). 
IX. Garantia de recursos financeiros proporcionais ao número de alunos e às necessidades da escola, distribuídos diretamente às unidades de ensino para o custeio de suas atividades pedagógicas e administrativas e para investimentos de manutenção com padrão de qualidade estabelecido pelo sistema, com a participação de todos os segmentos da comunidade escolar. (GDF, 1995).

Entre outras regulamentações próprias do processo em si e previsões de situações específicas, atribuindo atividades, prazos e condutas, a lei evidencia um processo democrático que, até então, não havia sido vivenciado no sistema educacional do DF e muito de sua redação é observado nas novas leis que se seguiram.

Já com o advento da Lei de Gestão Democrática da Escola Pública, em 1995, foi retirado do domínio do Estado à designação da função por interesses políticos de Governo, o que de certa forma dava à instituição e aos seus gestores "autonomia" administrativa e pedagógica.

Em 2007, ratificando os princípios de democracia, nova legislação foi decretada no DF. A Lei o 4.036 de 25 de outubro de 2007, publicada no Diário Oficial do Distrito Federal - DODF de 26.10.2007, que mantinha alguns traços da lei anterior e estabelecia outros. Conhecida como Lei da Gestão Compartilhada, teve por objetivos:

I. Implementar e executar as políticas públicas de educação, assegurando a qualidade, a equidade e a responsabilidade social de todos os envolvidos;

II. Assegurar a transparência dos mecanismos administrativos, financeiros e pedagógicos;

III. Otimizar os esforços da coletividade para a garantia da eficiência, eficácia e relevância do plano de trabalho e da proposta pedagógica;

IV. Garantir a autonomia das instituições educacionais, no que Ihes couber pela legislação vigente, na gestão pedagógica, administrativa e financeira, por meio do Conselho Escolar, de caráter deliberativo;

V. Assegurar o processo de avaliação institucional mediante mecanismos internos e externos, a transparência de resultados e a prestação de contas à comunidade;

VI. Assegurar mecanismos de suporte para a utilização, com eficiência, dos recursos descentralizados diretamente às instituições educacionais; 
Aspectos de gestão peculiares a essa lei consistiam na definição, por exemplo, de características que o diretor deveria reunir para o exercício da função, assim transcritas no trecho que se segue:

I. Articular, liderar e executar políticas educacionais, na qualidade de mediador entre essas e a proposta pedagógica e administrativa da instituição educacional, elaborada em conjunto com a comunidade, observadas as diretrizes e metas gerais da política educacional definida para o Governo do Distrito Federal e o uso dos resultados das avaliações internas e externas como subsídio à construção da proposta pedagógica da instituição educacional;

II. Compreender os condicionamentos políticos e sociais que interferem no cotidiano escolar para promover a integração e a participação da comunidade escolar, construindo relações de cooperação que favoreçam a formação de redes de apoio e de aprendizagem recíproca;

III. Propor e planejar ações que, voltadas para o contexto socioeconômico e cultural em que a escola esteja inserida, incorporem as demandas e os anseios da comunidade local aos propósitos pedagógicos da escola;

IV. Valorizar a gestão compartilhada como forma de fortalecimento institucional e de melhoria nos resultados de aprendizagem dos alunos;

V. Reconhecer a importância das ações de formação continuada para o aprimoramento dos profissionais que atuam na instituição educacional, criando mecanismos que favoreçam o seu desenvolvimento;

VI. Cuidar para que as ações de formação continuada se traduzam efetivamente em contribuição ao enriquecimento da prática pedagógica em sala de aula e à melhoria da aprendizagem, com ênfase no acesso, na permanência e no sucesso do aluno;

VII. Acompanhar e avaliar o desenvolvimento da proposta pedagógica e os indicadores de aprendizagem, os resultados das avaliações externas e os indicadores de desempenho divulgados pelo Instituto Nacional de Estudos e Pesquisas Educacionais Anísio Teixeira INEP, do Ministério da Educação - MEC, com vistas à melhoria do desempenho da instituição educacional;

VIII. Conhecer os princípios e as diretrizes da administração pública e incorporá-los à prática gestora no cotidiano da administração escolar (GDF, 2007) 
Entre os diversos requisitos ${ }^{25}$ exigidos cumulativamente, destaca-se a necessidade de ser licenciado em qualquer área do conhecimento, preferencialmente, com especialização ou aperfeiçoamento em Gestão da Escola Pública. Com essa exigência preconizava-se a necessidade de conhecimento específico para o exercício da função, além de um período mínimo de 03 (três) anos de experiência em regência de classe, exigindo o conhecimento na docência para o exercício da função de gestor.

No processo seletivo estruturado em três etapas, era dado à equipe gestora o direito de designar três cargos de sua confiança: secretário escolar, supervisor pedagógico e supervisor administrativo.

As etapas do processo seletivo foram divididas em três momentos:

1) Avaliação do conhecimento de gestão escolar e análise de títulos;

2) Elaboração e apresentação do plano de trabalho;

3) Escolha pela comunidade.

Após concluir todas as etapas com êxito, diretor e vice tinham que se comprometer a realizar um curso de gestão oferecido pela SEDF e assinar termo de compromisso assumindo por 04 anos a responsabilidade por uma boa gestão à instituição, que seria avaliada a cada 02 (dois) anos. Tal processo sistematizou-se e permaneceu até fevereiro de 2012, quando foi decretada a Lei de Gestão Democrática do Sistema de Ensino Público do Distrito Federal ํㅜ 4.751 de 07 de fevereiro de 2012, que se encontra em vigor até a presente data.

Nesse terceiro momento de mudança legalista sobre gestão escolar, algumas mudanças ocorreram. Na Lei 4.751 (2012), os princípios e finalidades são a:

I. Participação da comunidade escolar na definição e implementação de decisões pedagógicas, administrativas e financeiras, por meio de órgãos colegiados, e na eleição de diretor e vice-diretor da unidade escolar;

\footnotetext{
${ }^{25}$ Pertencer ao quadro de pessoal do DF, ser integrante da carreira magistério com lotação na SEDF, ter experiência com regência escolar de 3 anos, ser licenciado em qualquer área de conhecimento e não ter sido apenado por processo administrativo disciplinar nos 3 (três) anos anteriores à indicação do cargo (GDF, 2007).
} 
II. Respeito à pluralidade, à diversidade, ao caráter laico da escola pública aos direitos humanos em todas as instâncias da Rede Pública de Ensino do Distrito Federal;

III. Autonomia das unidades escolares, nos termos da legislação, nos aspectos pedagógicos, administrativos e de gestão financeira;

IV. Transparência da gestão da Rede Pública de Ensino, em todos os seus níveis, nos aspectos pedagógicos, administrativos e financeiros;

v. Garantia de qualidade social, traduzida pela busca constante do pleno desenvolvimento da pessoa, do preparo para o exercício da cidadania e da qualificação para o trabalho;

VI. Democratização das relações pedagógicas e de trabalho e criação de ambiente seguro e propício ao aprendizado e à construção do conhecimento;

VII. Valorização do profissional da educação (GDF, 2012)

No que tange à função do gestor escolar, a definição de critérios para o preenchimento do cargo de diretor e vice-diretor volta a ficar restrita ao processo eleitoral, com a modificação que permite aos servidores de outras carreiras ${ }^{26} \mathrm{da}$ SEDF concorrerem ao cargo, desde que atuantes nas escolas. Retira-se a exigência de 3 anos de experiência no magistério para ambos os membros da chapa e propõese formação em serviço na área de gestão para os eleitos.

Outro item importante a ser destacado é que, com a implementação da Lei de Gestão Compartilhada (2007), a escola passa a receber do GDF um quantitativo financeiro, destinado pelo Programa de Descentralização Administrativa e Financeira - PDAF - para ser executado pela comunidade escolar, sob coordenação do gestor escolar. Embora a Lei 957 (1995) tenha mencionado no artigo $1^{\circ}$ inciso VIII a garantia de recursos financeiros para as escolas, ela não especifica ou cria um programa, como na Lei 4.036 (2007).

Entendido como principal articulador dos interesses coletivos, integrando esforços e trabalhado para o sucesso institucional, o gestor tem sua função diretamente relacionada ao desempenho escolar, mas "a administração, entretanto, não se ocupa do

\footnotetext{
${ }^{26}$ Atualmente nas escolas do DF temos três carreiras preenchidas por concurso público, distintas que agregam várias funções dentro das unidades escolares. A Carreira de Magistério destinada aos professores, a Carreira Única para os orientadores educacionais e a Carreira de Assistência que comporta os merendeiros, vigilantes, secretários escolares, porteiros, entre outros.
} 
esforço despendido por pessoas isoladamente, mas com o esforço humano coletivo" (PARO, 2012, p. 31). Assim, a gestão deve ser assumida por todos através de um entendimento comum que preconize a concepção de gestão democrática.

Partindo de uma concepção de escola e de educação como propulsoras de transformação social, devem-se estabelecer em sua administração processos descentralizadores que dividam as responsabilidades e que, convertidos em valores coletivos, possam ser transpostos para além de seus muros. Transformar a escola num lugar onde se desenvolvem novas experiências e competências é responsabilidade de todos: diretores, pais, professores, alunos e funcionários. Conforme afirma Paro (2012, p.199),

[...] a possibilidade de uma administração democrática no sentido de sua articulação, na forma e no conteúdo, com os interesses da sociedade como um todo, tem a ver com os fins e a natureza da coisa administrada. No caso da Administração Escolar, sua especificidade deriva, pois: a) dos objetivos que se buscam alcançar com a escola; b) da natureza do processo que envolve essa busca.

Perceber as contradições sociais e enfrentá-las, promovendo reflexões e diálogo coletivo dentro da escola é dever do gestor escolar e também dos demais. Estando todos atentos aos interesses ideológicos da escola e da sua comunidade, devem-se perseguir métodos, técnicas e princípios coerentes com a educação transformadora, realizando uma administração reflexiva "como elemento imprescindível, já que ela representa, de forma intencional e consciente, a própria utilização racional desses recursos, quer por meio da racionalização do trabalho, quer por meio da coordenação do esforço humano coletivo" (PARO, 2012, p. 206).

[...] A atitude dos responsáveis pela Administração Escolar não pode ser a de aceitação incondicional de tais determinações e de mera operacionalização destas na escola, mas, pelo contrário, de desvelamento dos verdadeiros propósitos a que servem e, quando necessário, de sua reinterpretação e articulação com propósitos mais identificados com a transformação social (PARO, 2012, p. 201).

Criar mecanismos para que essa reflexão e participação realmente se efetivem consiste em garantir que interesses pessoais não sejam sobrepostos aos 
coletivos, que a consciência de classe ${ }^{27}$ prevaleça e que o anseio não se perca e desprenda da realidade prática. Caso contrário, o discurso e a inanição podem "inclusive, servir precisamente à causa oposta que os utiliza apenas como pretexto para encobrir seus verdadeiros propósitos" (PARO, 2012, p. 205).

Envolver, articular e promover a ação de pessoas nos processos escolares é uma ação complexa. Nessa ótica, o processo de gestão escolar ultrapassa os limites de atividades apenas pedagógicas e burocráticas, pois sua dimensão constitutiva é ampla, uma vez que articula relações humanas e seus diversos interesses.

$\mathrm{Na}$ LDBN 9.394/96, legislação vigente, a perspectiva de integração e socialização profissional do docente, embora não tenha sido expressa de maneira objetiva, pode ser incluída dentro do inciso VII, do artigo 3․ Nele é afirmado que a valorização do profissional da educação é um dos princípios pelos quais o ensino deva ser ministrado. Logo em seguida, no inciso VIII, diz-se que a gestão do ensino público fundamenta-se em processos democráticos.

A lei 4.751 dispõe sobre o Sistema de Ensino e a Gestão Democrática do Sistema de Ensino Público do DF atualmente vigente e corrobora com princípios da LDBN quando inclui entre as finalidades e princípios do ensino no artigo 2 o inciso $\mathrm{VI}$ que as relações pedagógicas e de trabalho devem ser democratizadas e que se deve criar um ambiente seguro e propício ao aprendizado e à construção do conhecimento. Ela ainda reitera, no inciso VII, a valorização do profissional da educação, mas não define papéis nem afirma que é uma função do gestor escolar, porque amplia a referência para toda a estrutura escolar e seus agentes.

As diretrizes pedagógicas da $\operatorname{SEDF}(2009$, p.17) afirmam que a formação de professores e gestores, inicial e em serviço é

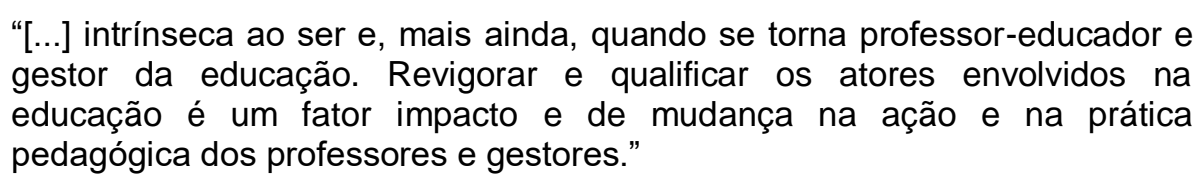

Desse modo, o processo de inserção na carreira se constitui um momento de consolidação de conhecimentos e apropriação profissional pela práxis que se

27 Entendida como sendo duas classes sociais contraditórias (burgueses e proletários) e de interesses inconciliáveis, que surgem com 0 advento do capitalismo na perspectiva marxista (Marx, 1989). 
caracteriza em uma aprendizagem e formação, necessitando de atenção, suporte e cuidado para um melhor desenvolvimento na carreira, que, expresso nas diretrizes pedagógicas, sinalizam seu impacto no desenvolvimento do trabalho docente e em seus resultados. Retomaremos esse aspecto mais adiante.

\subsection{A condição de professor iniciante e seu contexto profissional no DF}

Refletir sobre o processo de iniciação em uma carreira profissional, frequentemente leva-nos a dois sentidos, por um lado, o pensamento caminha rumo ao que se realizou antes de estar ali, ou seja, a formação inicial recebida e suas condições. Por outro, projetamos sonhos e ideais que nos levam ao sentido futuro da carreira, para além do ingresso, ou seja, o desenvolvimento profissional e a consolidação de um projeto de vida. Estabelecer o elo entre estes sentidos é caminhar rumo à constituição da relação teoria e prática.

Diante de uma diversidade de caminhos e suas consequências, o professor iniciante, via de regra, apresenta-se motivado e entusiasmado quando da efetivação de sua profissionalidade, "construída na relação que os sujeitos estabelecem, em suas práticas, com as demandas sociais internas e externas à escola, expressandose em modos próprios de ser e atuar como docente" (CRUZ; NETO, 2012, p.2).

Embora se saiba que na carreira docente o movimento é uma constante, a rotina nunca se consolida na totalidade, e a diversidade e complexidade das relações humanas não permitirão mesmo aos mais experientes, imunidade às dificuldades, a condição de professor iniciante, "é um momento dotado de características próprias, no qual, ocorrem as principais marcas da identidade e do estilo que vai caracterizar a profissional/professora ou o profissional/professor ao longo de sua carreira" (LIMA; CORSI, 2006, p.9).

Preocupado com a carreira docente, Huberman (2000) analisa o seu desenvolvimento defendendo um ciclo de vida profissional, conforme sintetizado no quadro que se segue: 


\section{Quadro 20 - Fases da carreira docente em Huberman (2000)}

\begin{tabular}{|c|c|}
\hline ANOS DE CARREIRA & FASES/TEMAS DE CARREIRA \\
\hline $1-3$ & Estabilização, Consolidação de um repertório pedagógico \\
$4-6$ & Siversificação, "Activismo" \\
$25-35$ & Serenidade, Distanciamento afetivo \\
$35-40$ & Conservantismo \\
(sereno ou amargo)
\end{tabular}

Fonte: Huberman (2000, p.47).

Pensando na questão da iniciação profissional no Brasil, o foco deste trabalho se limita aos 05 (cinco) primeiros anos da carreira, que em Huberman (2000) se inicia na primeira fase ("Entrada, Tacteamento") e se finaliza na metade da segunda fase ("Estabilização, Consolidação de um repertório pedagógico"). Para o autor essa sequência acontece no início da carreira se constituindo em exploração e estabilização. Vejamos como isso ocorre:

[...] A exploração consiste em fazer uma opção provisória, em proceder a uma investigação dos contornos da profissão, experimentando um ou mais papéis. Se esta fase for globalmente positiva, passa-se a uma fase de "estabilização", ou de compromisso, na qual as pessoas centram a sua atenção no domínio das diversas características do trabalho, na procura de um sector de focalização ou de especialização, na aquisição de um caderno de encargos e de condições de trabalho satisfatórias e, em vários casos, na tentativa de desempenhar papéis e responsabilidades de maior importância ou prestigio, ou mais lucrativas (HUBERMAN, 2000, p. 37).

Assim, muitos professores podem seguir na carreira, como docentes, podem esquivar-se dela buscando trabalhos administrativos no interior das instituições escolares, ou até mesmo, abandoná-las definitivamente. Atentar-se a estas condições e escolhas pode vir a promover o fortalecimento da carreira e talvez minimizar os problemas no âmbito educacional. 
Para Romanoswski e Soczer (2014, p. 1), "as estatísticas educacionais têm demonstrado, no Brasil, que o número de formandos licenciados está aquém das necessidades das demandas das escolas" e que políticas de formação de professores têm sido feitas para diminuir a falta destes. Contudo Pinto (2014, p. 3) aponta que,

[...] com exceção da disciplina de física, existem professores habilitados em número mais do que suficiente para assumir as turmas existentes, concluindo-se que se trata essencialmente de um problema de falta de atratividade da carreira docente.

Divergências à parte, quanto à demanda, André (2012, p. 3) aponta de qualquer forma, que há uma "evasão de professores melhor capacitados para a rede privada", indicando a necessidade de políticas públicas no país que versem sobre a permanência desse profissional na docência pública. Conforme o

[...] relatório, que reúne dados de 25 países mostra que a preocupação com a desistência de professores competentes, tem levado alguns países à adoção de políticas que possam não só atrair, desenvolver e recrutar bons profissionais, mas também criar condições para que os docentes queiram permanecer na profissão. Analisando as taxas de evasão do magistério em diversos países, o relatório informa que essas tendem a ser mais altas nos primeiros anos de atividade profissional (ANDRÉ, 2012, p. 3).

Romanowski e Soczek (2014, p. 2) alertam que "as reflexões realizadas não têm sido aproveitadas no sentido de fundamentar e construir uma política pública consistente de sustentação dos professores iniciantes nas escolas".

Assim, o que se percebe é uma crise no magistério e,

[...] esta carência se expressa por um lado, pela carreira de magistério não ser atrativa considerando os salários pagos e as condições de ensino nas escolas e, por outro, pela desistência dos professores nos primeiros anos de sua prática profissional, ou seja, poucos interessados e pouca perseverança na profissão (ROMANOWSKI e SOCZEK, 2014, p. 3).

Deste modo, torna-se importante estabelecer no início da carreira uma condição ímpar, preocupando-se com a inserção e permanência deste professor no ambiente escolar. Devido às constantes transformações socioeducativas e culturais da sociedade moderna, dar significado à profissão torna-se desafio, pois os saberes deste profissional são colocados em "cheque" frequentemente. Então o que ensinar? Quais deveriam ser os saberes dos professores? 
Segundo Roldão (2007, p. 95),

[...] a função específica de ensinar já não é hoje definível pela simples passagem do saber, não por razões ideológicas ou apenas por opções pedagógicas, mas por razões sócio-históricas. O entendimento de ensinar como sinônimo de transmitir um saber, deixou de ser socialmente útil e profissionalmente distintivo da função em causa, num tempo de acesso alargado à informação e de estruturação das sociedades em torno do conhecimento enquanto capital global.

Pelo fato de não ser consensual a definição do ato de ensinar e pela profissionalização do docente não ser linear, nem unidirecional, a postura tradicional de transmitir saberes por parte do docente, se integra a processos mediadores, não por razões ideológicas, nem pedagógicas, mas por razões sócio-históricas, descobrindo o prazer na profissão e tendo com ela uma relação afirmativa, segura e reflexiva. Os saberes pedagógicos são vastos, mas dominar suas bases dá segurança ao docente diante das adversidades, passando a estabelecer uma relação híbrida com o conhecimento e então buscar novas formas de lidar com sua constituição profissional.

Roldão (2007) aponta algumas especificidades da profissão a serem incorporadas aos saberes docentes. Primeiro elemento se constitui na natureza da composição de seu trabalho, que deve se dar incluindo elementos que se transformem de maneira coerente. Um segundo elemento desta especificidade é a sua capacidade analítica de possuir um saber técnico, somá-lo à sua capacidade de improvisação e criatividade e gerar um novo conhecimento profissional. Outro elemento é a sua capacidade de mobilização investigativa, questionando permanentemente sua prática, conhecimentos declarados (cientificamente como formalmente aceitos) e suas experiências. Este profissional deve ainda, realizar sempre uma meta-análise desenvolvendo uma postura de direcionamento e autocrítica. E por fim, promover a divulgação e circulação de seus conhecimentos tácitos, submetidos a uma meta-análise e transformando-os em saberes articulados e sistemáticos.

Diante desta complexa função o professor iniciante precisa de um apoio de seus pares, tendo em vista suas inseguranças, limitações e dificuldades. Exemplificando algumas das características pertinentes a essa fase da carreira temos: 
- Necessidade de controle das situações, insegurança, preocupações, submissão à opinião dos profissionais que os professores iniciantes consideram superiores ou mais experientes;

- Aprendizagens intensivas por processos de tentativas e erros e geração de expectativas e sentimentos fortes e por vezes contraditórios que podem no limite, determinar a continuidade ou não da profissão;

- Elevado conformismo às normas e regras sociais existentes na realidade de ensino e desejo de agradar a seus pares;

- Tendência para se identificar com os valores e crenças da maioria;

- Do ponto de vista das teorias da aprendizagem de adultos, os professores, quando se iniciam na profissão logo após terem concluído a formação inicial, estão em fase de exploração das possibilidades da vida adulta e de início de elaboração de uma estrutura estável de vida; assim, os problemas de disciplina são os que mais os preocupam, já que eles manifestam uma ausência de autoridade;

- Preocupação com o domínio dos conteúdos;

- "Choque com a realidade" (expressão cunhada por Veenman); configura-se como a diferença encontrada pelos professores entre a idealização da realidade - segundo suas vivências anteriores, em especial o que the foi apresentado no curso de formação inicial - e a realidade tal qual ele agora vivencia, pessoalmente, na inserção profissional;

- Experimentação de diversos modelos de ensino, embora não seja capaz de refletir sobre a escolha de um ou outro;

- Auto-proteção e concretismo cognitivo;

- Prevalência dos problemas didáticos sobre os pessoais ou organizacionais, embora nesse período, se registrem importantes transformações em nível pessoal;

- Diferenciação em função dos contextos de atuação;

- Forte influência das experiências vividas enquanto estudantes (LIMA; CORSI, 2006, p. 12).

Esse período de transição entre formação inicial e incorporação ao mundo do trabalho é considerado por Vailant e Garcia (2012) como sendo a etapa de inserção profissional e, portanto, sendo importante o "apoio e supervisão, assim como uma avaliação formal para certificar a aquisição de destrezas, sem as quais os docentes não poderiam ter acesso à profissão" (VAILLANT; GARCIA, 2012, p. 123). 
Assim, na perspectiva de apoio a esse professor, temos entre os vários elementos presentes na escola, o gestor escolar, com uma função pautada ao longo da história, em interesses político/ideológico do estado, manifestado nas ações, conceituações e processos administrativos presente nas escolas.

Considerando que a perspectiva do seu trabalho pode perpassar tanto a concepção autoritária, quanto a participativa, torna-se importante uma reflexão constante e coletiva, das funções, dos interesses e da realidade do contexto escolar.

No DF, a perspectiva de uma gestão democrática, estabelecia por força de lei ocorreu em três momentos (1995, 2007 e 2012) que embora com enfoques diferentes, carregaram em suas essências os mesmos princípios de autonomia, questionáveis quanto aos interesses da iniciativa, visto que, ao mesmo tempo em que oferta descentralização e a autonomia à instituição, desobriga o estado de algumas responsabilidades e permite uma maior cobrança sobre o gestor, intensificando o seu trabalho. 


\section{O SENTIDO DO OBJETO A PARTIR DOS RESULTADOS}

Para enfrentar as mudanças, a ação e a reflexão atuam simultaneamente. (Libâneo, 2004)

Este capítulo reapresenta o percurso e a consolidação da amostra, apresenta o perfil de seus sujeitos e discute as categorias evidenciadas a respeito dos aspectos que envolvem a atuação dos gestores no processo de inserção dos professores iniciantes e seus impactos no desenvolvimento do trabalho docente.

\subsection{Síntese da amostra}

Nesta pesquisa o trabalho de "estado da arte" e aplicação dos questionários para professores iniciantes foram realizados em conjunto com o GEPFAPe, só depois se desmembrou passando a realizar um trabalho de caráter mais específico.

Assim, a primeira etapa de pesquisa de campo realizada em conjunto com o grupo de estudo, foi realizar um diagnóstico do quantitativo de professores efetivados pela SEDF no período de 2010 a 2014, onde se identificou 4663 profissionais contratados e distribuídos na rede. Deste total, constatou-se que as regionais de Ceilândia (836), Planaltina (408), Recanto das Emas (404), Samambaia (386) e Santa Maria (359), somadas (2393) receberam o correspondente a 51,31\% do total de contratados, montante expressivo para a demarcação inicial.

Feito isto, partiu-se para o levantamento do quantitativo de professores por escolas nestas respectivas regionais, identificando a unidade escolar por regional de ensino que receberam o maior número de professores iniciantes. Tal apuração realizada permitiu definir 05 escolas já cognominadas por letras ( $A, B, C, D$ e E), tendo-se por propósito conferir o anonimato aos sujeitos e o ético andamento da pesquisa.

Diante deste universo amostral, foram distribuídos ${ }^{28} 70$ questionários para docentes recém-contratados e 05 questionários para seus respectivos gestores e

28 Em virtude do tamanho do questionário e as demandas das escolas, foi solicitado pelos sujeitos que os questionários fossem distribuídos e recolhidos posteriormente em dia a ser agendado com a escola. 
deste montante, 39 foram respondidos por professores e 05 por gestores, conforme apresenta o gráfico:

\section{Gráfico 1 - Retorno dos questionários}

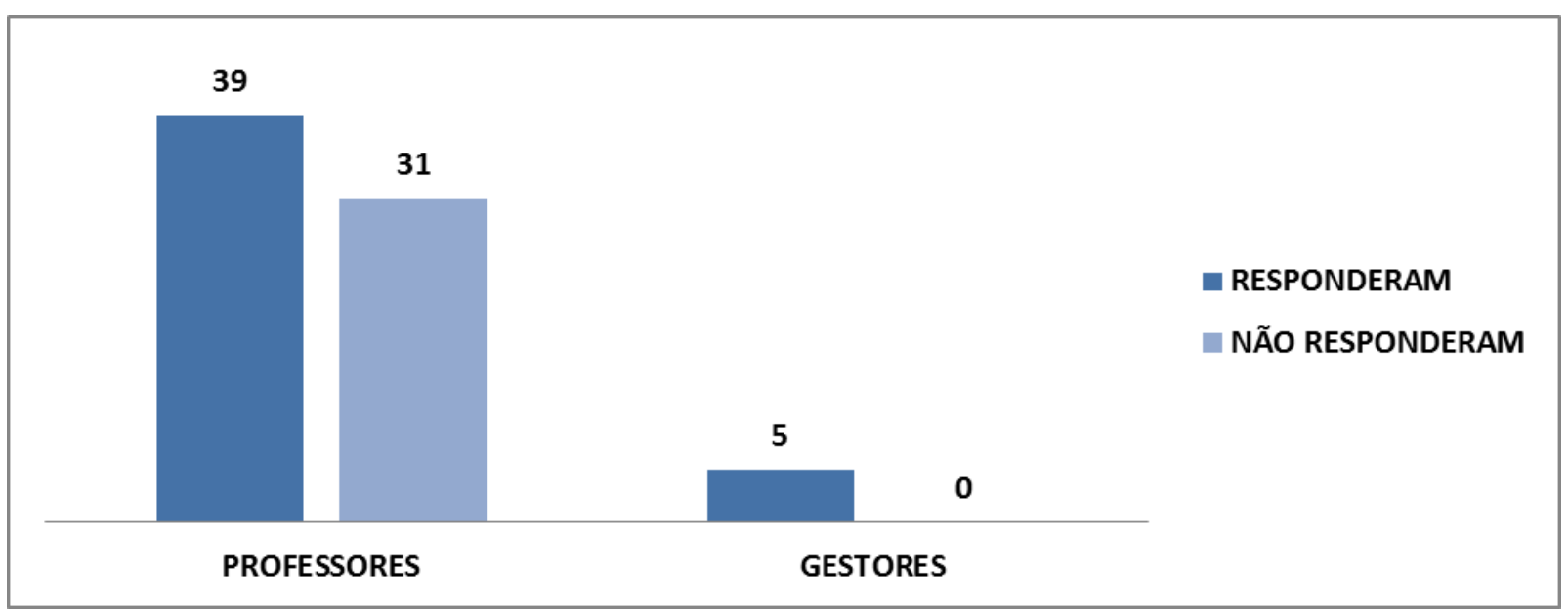

Fonte: Elaborado pela autora da pesquisa.

A partir deste momento $o$ trabalho se desmembrou e a análise, se estabeleceu isoladamente abordando os aspectos da gestão.

Apenas 11 professores atendiam às condições de serem iniciantes, ou seja, com até cinco anos de atividade docente e sem experiência docente prévia, visto que, apresentam características distintas dos professores ingressantes.

\section{Gráfico 2 - Professores iniciantes/ingressantes}

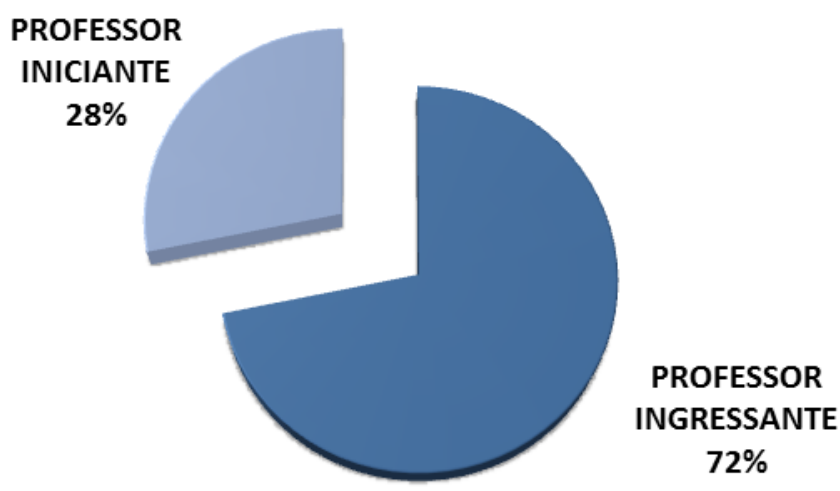

Fonte: Elaborado pela autora da pesquisa com base na questão número 08 do questionário dos professores iniciantes. 
O questionário semiestruturado com 46 questões (Apêndice 2), foi elaborado em conjunto com o GEPEFAPe para pesquisa com professores iniciantes envolvendo vários objetos de estudos e seus respectivos pesquisadores, mas para este foram analisadas as questões $(01,02,06,08,09,12,15,16,17,18,19,20,25,27,30$ e 35$)$ pois tratam da relação professor iniciante e gestor escolar.

Aos participantes (professores iniciantes e gestores) da primeira etapa (questionário) foi perguntado quanto da possibilidade de participação em uma segunda fase (entrevista) e obteve-se a seguinte demanda:

\section{Gráfico 3 - Participação na entrevista}

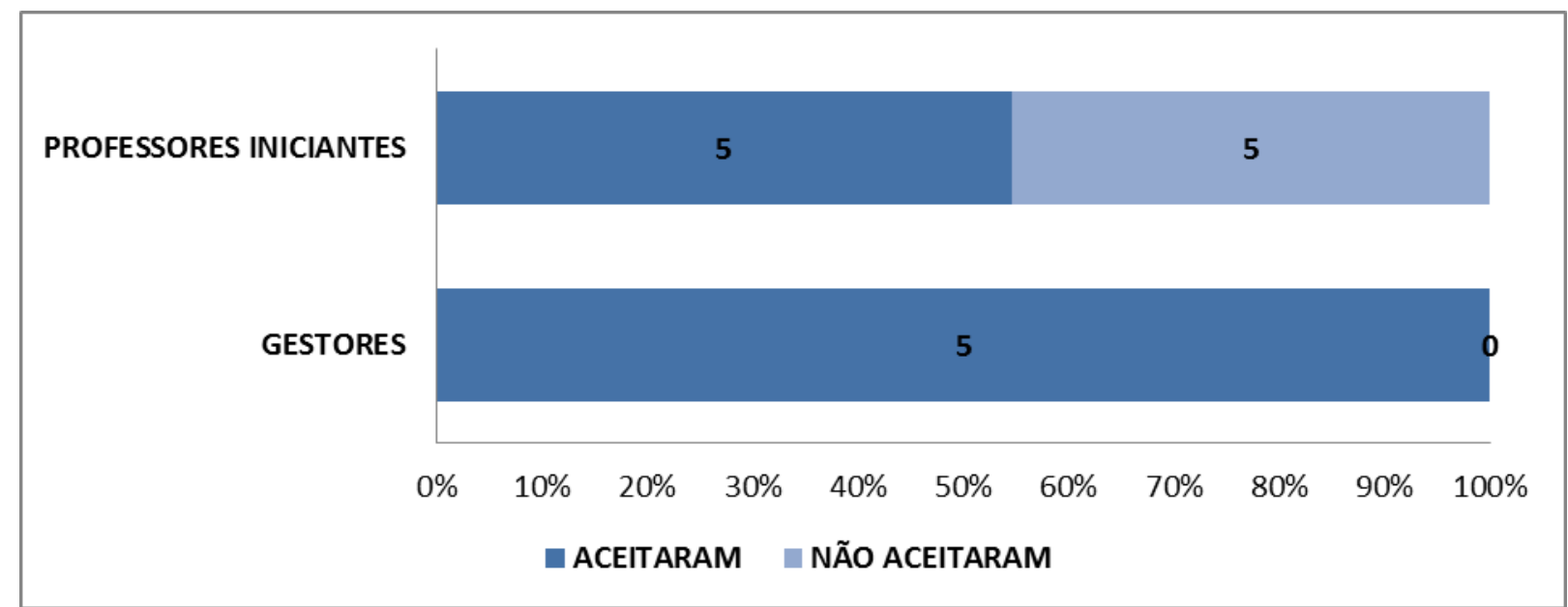

Fonte: Elaborado pela autora da pesquisa.

Conforme demonstrado no gráfico, apenas 05 (cinco) professores iniciantes aceitaram ser entrevistados. Quanto aos gestores foi possível realizar com todos, totalizando, nesta etapa, 05 professores e 05 gestores entrevistados.

Nas entrevistas buscou-se estabelecer um diálogo, de modo que fosse possível ao entrevistado discorrer livremente sobre os temas constantes do roteiro de entrevista (apêndice 3 e 4), sendo interpelado apenas no caso de um devido esclarecimento de informações, com intuito de clarificação da resposta. Todas foram gravadas e transcritas e tiveram suas interpretações pautadas na abordagem técnica da análise de conteúdo que consiste em "um conjunto de técnicas de análises das comunicações" (BARDIN, 2011, p.37) trabalhando a fala nas respostas, com uma abordagem analítica do materialismo histórico dialético. 
Tal análise "leva em consideração as significações (conteúdo), eventualmente a sua forma e a distribuição desses conteúdos e formas (índices formais e análise de ocorrência)" (BARDIN, 2011, p.49) e permite desvelar o que está por trás das palavras analisadas, mediante o uso semântico na compreensão do significado e lexicológico que aplica estatísticas de repetições e incidência de palavras.

\subsection{Perfil dos sujeitos no contexto da pesquisa}

\subsubsection{Gestores}

Os dados mostram que dos 05 gestores pesquisados, 04 (80\%) tem a idade variante entre 36 a 45 anos ou mais, equiparando-se à média nacional observada no relatório da Pesquisa Internacional sobre Ensino e Aprendizagem - TALIS (2014, p.10), que é de 45 anos. O mesmo relatório afirma também, que nas escolas brasileiras estariam presentes os diretores mais novos (45 anos) dentre todos os países pesquisados.

Considerando suas experiências profissionais, 05 gestores (100\%) possuem mais de 10 anos na educação e 04 (80\%) já atuam na SEDF a mais de 10 anos, estando familiarizados ao ambiente e aos procedimentos adotados na SEDF e se constituindo num investimento de tempo para a consolidação de uma carreira profissional que the permite compartilhar experiências e conhecimentos com o trabalho dos demais docentes.

Com $05(100 \%)$ gestores formados em especialização, 04 (80\%) possuem curso específico em gestão escolar, supostamente poderíamos inferir que

[...] isto tem conexão tanto com as exigências da lei como ao necessário aperfeiçoamento e qualificação profissional, como também em relação aos planos de carreira docente que incorporam elementos como aumento no nível de formação para crescimento e melhor remuneração na carreira (OLIVEIRA, 2012, p. 26).

Mas, há um percurso histórico que acompanha a função e perpassa mecanismos legais criando especificidades para o gestor escolar.

“[...] Em 1958, houve a exigência do curso pós-normal em administração escolar [...] com duração de dois anos [...] prática que foi se estabelecendo, visando a uma formação mais aprimorada desses profissionais" (ANDREOTTI, LOMBARDI e MINTO, 2012, p. 141). 
Esta perspectiva vem sendo reafirmada no campo educacional ao longo da história e no DF atualmente está regulamentada pela Lei 4.571/2012 que dispõe sobre o sistema de ensino e a gestão democrática do sistema de ensino público do DF, que trata em seu artigo 38, parágrafo único, inciso IV da:

[...] Participação dos eleitos em curso de gestão escolar oferecido pela SEDF, visando à qualificação para o exercício da função, exigida frequência mínima de setenta e cinco por cento.

Assim, a formação não se constitui apenas em uma necessidade do individuo diante das demandas do trabalho, mas uma imposição para o exercício da função, uma vez que seu entendimento estaria muito atrelado às concepções técnicas dadas à administração geral. "Essa identificação fica bastante visível na exigência, que normalmente se faz, de que o diretor de escola tenha uma formação em administração escolar (ou gestão escolar)" (PARO, 2015, p.37).

A exigência de formação em administração, amparada na "defesa dos procedimentos administrativos na escola sob a forma de adesão ao emprego, aí, dos princípios e métodos desenvolvidos e adotados nas empresas capitalistas" (PARO, 2012, p.17), estaria atrelada à concepção de que a escola costuma necessitar de processos administrativos semelhantes aos de empresas do ramo da produção econômica. Assim, "o espírito que rege o tratamento dado ao diretor de escola e as expectativas que se tem sobre ele são cada vez mais semelhantes ou idênticas ao modo de considerar o típico diretor de uma empresa capitalista" (PARO, 2015, p.42).

Apoiado na tendência mercantilista estabelecida na educação onde a política indiscriminada por resultados consolida processos cruéis de cobrança, a administração escolar acaba sendo dividida entre trabalho administrativo e trabalho pedagógico. Ao contrário do que ocorre em outros tipos de produção, "o professor como trabalhador precisa envolver-se (politicamente) com o educando, seu objeto de trabalho por excelência" (PARO, 2015, p.66) e, portanto, construir a relação entre administrativo e pedagógico.

Ao relacionarmos a experiência na função com o tempo que possuem trabalhando como diretores ou vice-diretores, na atual escola, observa-se que este é basicamente o mesmo, ou seja, estas se constituem em suas únicas experiências 
como gestores escolares, remetendo-nos ao entendimento de que ainda se encontram em aprendizagem prática dos processos de gestão. Observe no gráfico abaixo o tempo de experiência dos gestores na função:

\section{Gráfico 4 - Experiência dos gestores na função}

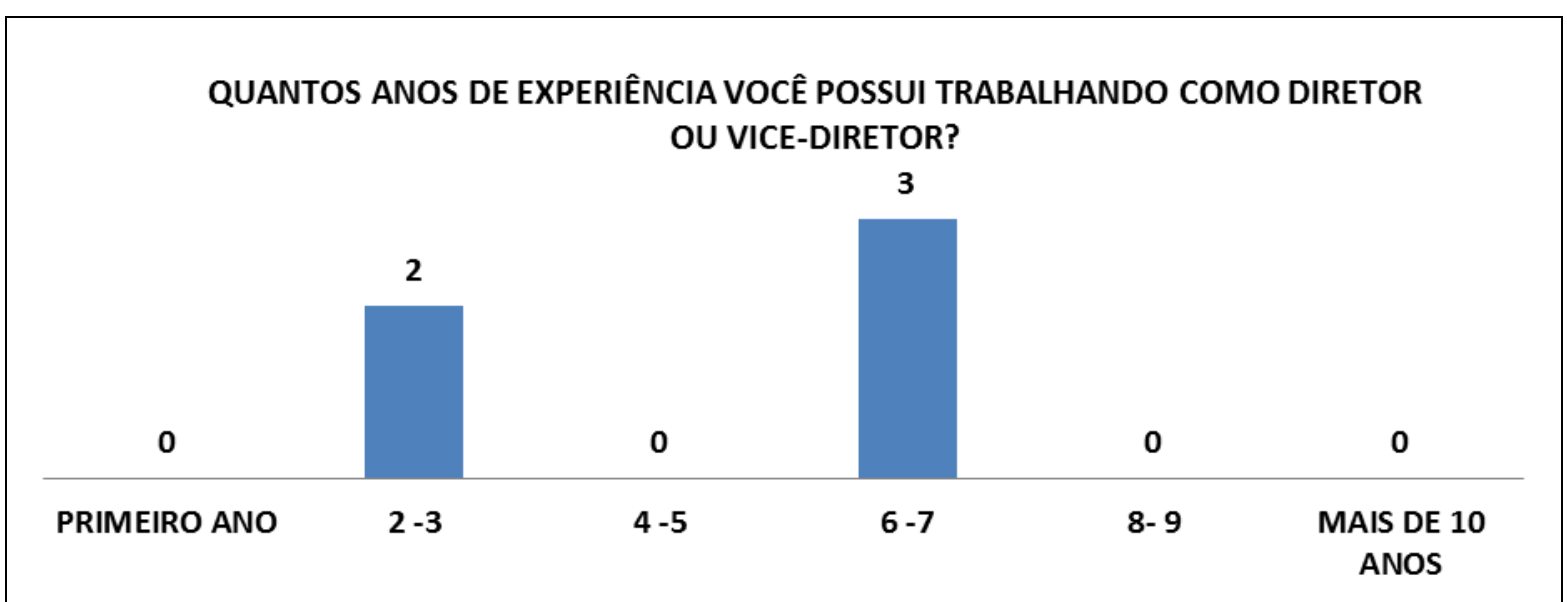

Fonte: Elaborado pela autora da pesquisa com base na questão número 20 do questionário dos gestores.

Embora haja um tempo maior de profissão e experiência com a docência, os gestores pesquisados possuem um tempo relativamente menor na função de gestor que coincide com o tempo de gestão na unidade escolar em que se encontram atualmente. Vejamos o gráfico seguinte:

\section{Gráfico 5 - Experiência como gestor na atual unidade escolar}

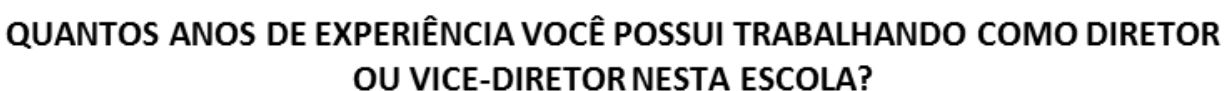

OU VICE-DIRETOR NESTA ESCOLA?

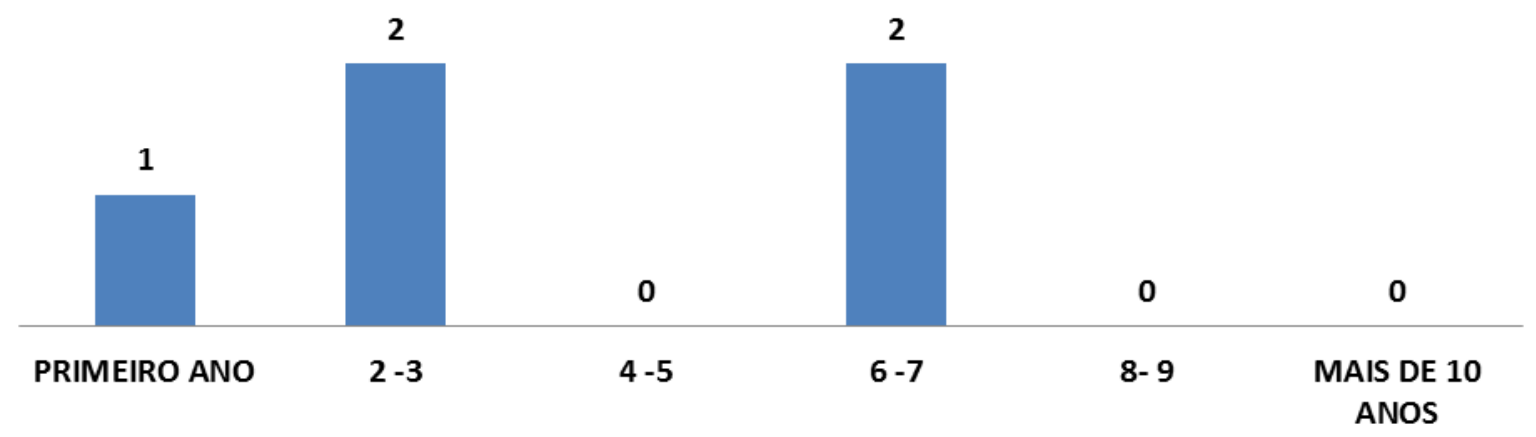

Fonte: Elaborado pela autora da pesquisa, com base na questão número 21 do questionário dos gestores. 
Assim, os gestores estudados apresentam experiência menor na função e que praticamente esta se constitui em sua única experiência administrativa.

Com expressiva representatividade feminina numa predominância de mais de $80 \%$ de mulheres e já neste quesito superando a média nacional de $75 \%$ e se distanciando da média mundial de $49 \%$ apresentada pelos países participantes (TALIS, 2014 p.10), temos o seguinte panorama:

\section{Gráfico 6 - Panorama das mulheres em gestão escolar}

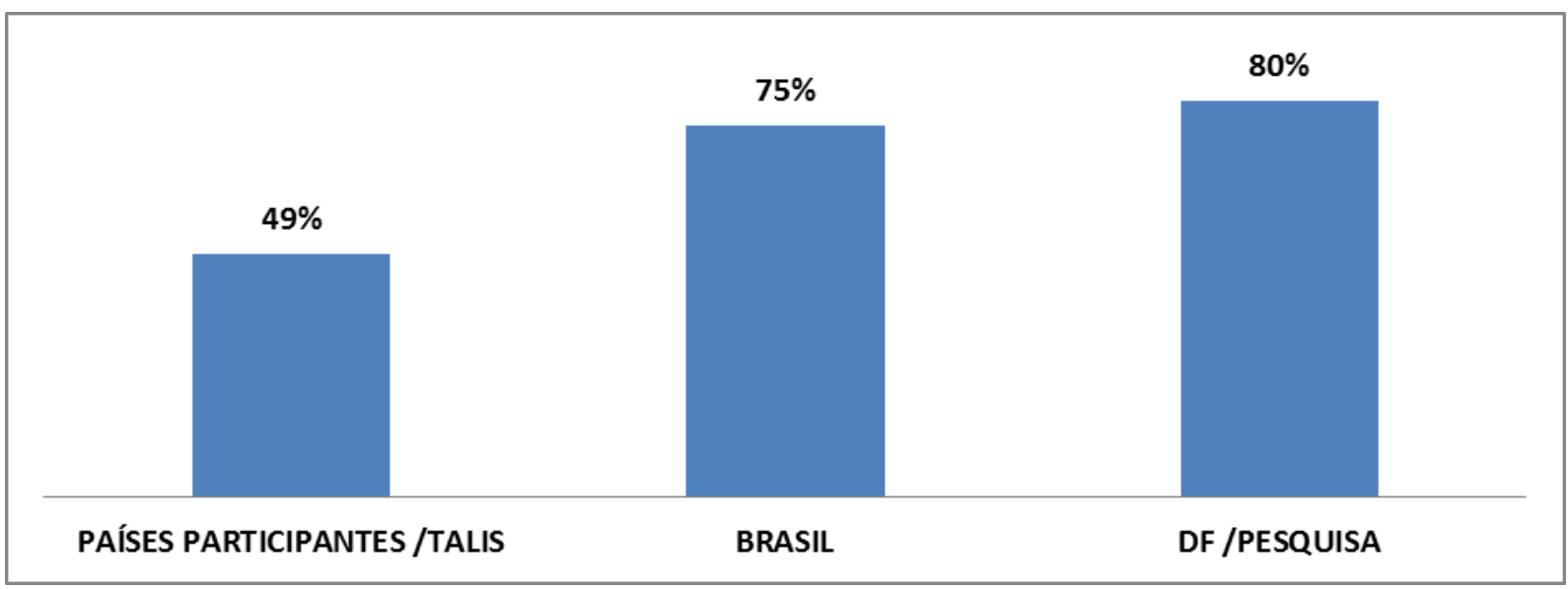

Fonte: Elaborado pela autora da pesquisa.

Segundo Apple (1995, p. 10) o ato de ensinar tem sido historicamente uma tarefa de mulheres, visto que os homens a abandonaram em virtude do custo de oportunidade que ficou muito alto para permanecer no magistério, "e como a atividade docente [...] tem componentes de cuidar de crianças e servir, isso ajuda a reconstruir sua definição como trabalho de mulher".

Sabe-se que a educação sempre se constituiu em um campo de muitas disputas, que acabam por representar uma realidade social. Para Apple (1995) o fato de as mulheres estarem predominantemente representadas em determinados extratos profissionais estaria ligado a duas condições: a desvantagem em relação aos homens e a concentração em trabalhos específicos, onde geralmente a remuneração é inferior, afirmando que "setores ocupacionais competitivos, de baixos salários, têm uma ampla presença feminina" (1995, p.54), e ao considerar que na educação brasileira a disputa pela valorização profissional é muito acirrada e presente, explica-se assim, o domínio feminino neste contexto. 
O resultado de mulheres na função de gestoras escolares, apresentado nas escolas estudadas, aponta uma alteração da condição de gênero em suas lideranças no que tange as unidades escolares, visto que não foram avaliadas outras instâncias administrativas da SEDF, refletindo um movimento de ascensão feminina em postos de liderança no trabalho.

Essa mudança supera a ideia apresentada por Apple (1995, p.46) de que sua administração é predominantemente masculina e às mulheres compete apenas a docência, conforme autor afirma no trecho a seguir:

[...] O impacto da desqualificação e da intensificação ocorre num terreno e numa instituição que são habitados principalmente por docentes do sexo feminino e administradores masculinos, um fato que necessita ser reconhecido como estando historicamente articulado tanto com as divisões sociais quanto sexuais do trabalho, do conhecimento e do poder em nossa sociedade.

Fato é que as intensas lutas pela democratização das esferas educacionais vêm refletindo ao longo dos anos em mudanças nas condições de gênero no ambiente escolar do DF. Pensar nas origens desse processo de alternância caberia outro estudo mais aprofundado sobre a questão.

O Distrito Federal não possui uma carreira específica para gestores escolares preenchidas por concurso público, atuando em conformidade com o parágrafo único do artigo 67 da LDBN 9.394/96 que afirma ser a experiência docente "pré-requisito para o exercício profissional de qualquer outra função de magistério, nos termos das normas de cada sistema de ensino", assim o ingresso se dá prioritariamente pela docência.

Dos 05 gestores, 03 foram eleitos, 01 participou de seleção (prova de conhecimentos sobre educação e conhecimentos de gestão escolar) mais eleição e 01 gestor está no cargo em virtude de indicação. No Distrito Federal a gestão democrática que tem como um dos princípios a eleição de gestores escolares se ampara atualmente na Lei 4.751 de $07 / 02 / 2012$, ou seja, os que afirmam terem passado por um processo de seleção e eleição provavelmente foram reconduzidos a um segundo mandato, visto que, a Lei de Gestão Compartilhada 4.036 de 25/10/2007 que previa seleção e eleição vigorou até 06 de fevereiro de 2012, assim 
provavelmente permitindo um segundo mandato a este gestor. O caso em que se constitui de indicação caracteriza-se pela criação ${ }^{29}$ da unidade escolar.

O pressuposto democrático de participação na gestão do ensino público é garantido pela constituição no seu artigo 206 onde a gestão da educação brasileira deve ser democrática e participativa, assim, em consonância a LDBN 9.394/96 em seu artigo 3o inciso VIII afirma que a gestão do ensino deve ser democrática respeitando a forma da lei e da legislação dos sistemas de ensino, dando autonomia aos federados de definirem seus processos democráticos de gestão.

Embora saibamos que estabelecer em lei as diretrizes democráticas dos sistemas de ensino não garanta sua efetivação na prática, ao tentar permitir a participação de todos em processos decisórios nas instituições sociais através de artifícios legais configura-se em uma iniciativa que deve ser fortalecida. A forma como os gestores escolares são escolhidos pela comunidade pode ser o primeiro passo na mudança.

O processo de gestão democrática nas instituições educacionais confere aos eleitos a legitimidade na função, ao mesmo tempo em que lhes exige a proximidade com os interesses da comunidade, podendo influenciar na conduta do gestor na medida em que vai dando sentido aos objetivos de sua gestão. Contudo, o processo eleitoral não garante por si só que a administração escolar seja articulada no sentido da superação da ordem social existente, mas desqualificá-lo é arriscado, muito embora ele não se resuma a um fim em si mesmo. O interessante é a manutenção constante do debate a respeito e a vigilância de seus princípios e processos, visto que agrega elementos de participação ao processo educativo, pois,

[...] a administração se constitui em instrumento que, como tal, pode articular-se tanto com a conservação do status quo quanto com a transformação social, dependendo dos objetivos aos quais ela é posta a servir. A recuperação desse caráter instrumental de toda administração é de importância decisiva para o exame da atividade administrativa em nossas

29 Art. 45. Para cada unidade escolar recém-instalada, serão designados pela SEDF servidores para o exercício dos cargos de diretor e vice-diretor, devendo o processo eleitoral ser realizado em até cento e oitenta dias e a direção eleita nesta hipótese exercer o restante do mandato até a posse dos candidatos eleitos na eleição geral seguinte. Parágrafo único. Na hipótese de criação de unidade escolar em ano de eleições gerais para diretor e vice-diretor, a equipe indicada na forma do caput permanecerá até a posse dos candidatos eleitos naquele processo eleitoral. (GDF, 4.751, 2012). 
escolas, já que, somente a partir desta perspectiva, é possível conceber a possibilidade de uma Administração Escolar voltada para a transformação social (PARO, 2012, p. 162).

De acordo com os dados internacionais da pesquisa TALIS 2014, coordenada pela Organização para a Cooperação e Desenvolvimento Econômico - OCDE, (53\%) dos gestores trabalham em tempo integral sem obrigação docente na direção das escolas (TALIS, 2014, p.11), mas não aponta de quanto seria esse tempo. Ao alinharmos esta informação às dos gestores por nós pesquisados, observa-se que quanto ao regime de trabalho 03 gestores $(60 \%)$ afirmam atuar dentro do limite previsto de 40 horas semanais e 02 gestores (40\%) afirmam sobrecarga ao trabalharem mais do que o estabelecido legalmente, sugerindo a necessidade de realização de estudos quanto à possibilidade de intensificação do trabalho do gestor.

As escolas estudadas possuem atendimentos diferenciados, mas todas pertencem à educação básica, indo desde a educação infantil até o ensino médio. Os turnos de atendimento escolar são: matutino, vespertino e noturno, sendo que uma das unidades atende turno único ${ }^{30}$, caso específico de escolas de educação de tempo integral.

Localizadas na zona urbana, não estando necessariamente centralizadas, pelo contrário, a maioria, 04 escolas (80\%) está na área periférica dentro da própria cidade e as 05 cidades (100\%) estão situadas em regiões periféricas ${ }^{31}$ do DF de pouco poder aquisitivo (ver quadro da página 25).

Do ponto de vista de que a condição de localização pode ocasionar dificuldades administrativas e pedagógicas na condução das atividades escolares, uma vez que, a precarização ocasionada pela condição geopolítica, interfere na socioeconômica, cultural, física, docente... Enfim são múltiplas determinações que afetam as condições gerais da atividade gestora, acirrando ou minimizando os impactos sociais. Este cenário é um reflexo social, transposto à escola, integrandose a uma desigualdade sistêmica da rede do DF, que provoca desvantagens administrativas e pedagógicas para instituição escolar, suas relações e seus respectivos resultados.

\footnotetext{
30 Horário das 7 h30 às 17 h30, com intervalo para almoço.

31 Considerando Brasília Capital, como sendo o centro geopolítico do Distrito Federal.
} 
Se considerarmos ainda, que as CREs que surgiram no campo da pesquisa são todas de lotação ${ }^{32}$ e não de remoção ${ }^{33}$, situadas nas extremidades do DF, passíveis de movimentação frequentes de professores e que geralmente adotam processos que seguem um

[...] critério meritocrático que tem como um de seus critérios de hierarquização e seleção o item "tempo de serviço", não raro que algumas escolas localizadas nas periferias dos centros urbanos ou com classificação de risco, o quadro de professores seja formado em sua maior parte por principiantes, sem contar com a possibilidade de trocas e ajuda de professores experientes, pois o quadro de professores não conta com tais docentes (ROMANOWSKI e SOCZEK, 2014, p. 3).

Podemos inferir que seus respectivos gestores terão um quadro de docentes em contínuo processo de movimentação, no qual estaria sempre recebendo professores novos, tendo em suas unidades certo grau de rotatividade, o que intensifica o trabalho de suporte aos professores iniciantes e exige mais do gestor escolar no sentindo de apoio ao trabalho do corpo docente.

Ao se reproduzirem nas escolas as desigualdades sociais que se dão por necessidades econômicas e se estabelecem basicamente pelo processo produtivo na sociedade exige muito mais dos gestores escolares e, portanto, verifica-se que

[...] o conceito de reprodução das relações de produção incidem sobre a totalidade, sobre o movimento dessas sociedades ao nível global e impulsionam aquelas análises que ficam apenas na exterioridade recíproca das instituições. A dialética reprodução-contradição-totalidade permite perceber como as instituições não só refletem as estruturas mais amplas, mas também cooperam para produzir e reproduzir as relações sociais (CURY, 2000, p. 41).

Integrar perspectivas administrativas para promover mudanças no contexto social exige dos gestores conhecimento, objetividade, proximidade com a causa, esforço e adequação dos meios aos fins, muito embora saibamos que a

32 Coordenações Regionais de Ensino nas quais o servidor da Carreira Magistério Público adquire lotação, quando do seu encaminhamento na posse do cargo público e na efetivação do Procedimento de Remanejamento Externo ou permuta. São elas: Brasilândia, Ceilândia, Gama, Planaltina, Samambaia, Paranoá, Santa Maria, São Sebastião e Recanto das Emas (GDF, PORTARIA №219, 2014) e possuindo um caráter provisório.

${ }^{33}$ Coordenações Regionais de Ensino nas quais o servido da Carreira Magistério Público adquire lotação somente por Procedimento de Remanejamento Externo ou permuta. São elas: Plano Piloto, Guará, Núcleo Bandeirante, Sobradinho e Taguatinga. (GDF, PORTARIA №219, 2014), apresenta um caráter mais definitivo. 
"administração, entretanto, não se ocupa do esforço despendido por pessoas isoladamente, mas com o esforço humano coletivo" (PARO, 2012, p.31).

Percebe-se que quanto mais complexas são as condições, mais difíceis se tornam às soluções, sem contar que estas exigem uma administração coerente e precisa, no sentido de transformar a realidade encontrada, trabalhando com os escassos recursos de que se dispõe, esse desafio consiste num dos grandes dilemas inerentes ao trabalho do gestor escolar.

\subsubsection{Professores iniciantes}

Dos 11 professores pesquisados, 09 professores $(81,82 \%)$ possuem uma idade variante entre 26 e 35 anos. Conforme Oliveira (2012, p. 23) afirma "os docentes iniciam em média, sua vida profissional aos 22/23 anos de idade" o que significaria dizer que os professores iniciantes desta pesquisa o fizeram bem mais tarde.

Ao considerar que estes professores já concluíram ou estão concluindo o curso de especialização, ou seja, 11 professores (100\%) já iniciaram suas carreiras com uma etapa superior à formação inicial requerida. Evidenciamos aqui, um expressivo interesse na formação continuada antes da efetivação do ingresso na carreira, o que certifica acima do exigido para o ingresso a capacidade formativa destes profissionais.

As capacidades docentes se constituem em

[...] elemento essencial na adequada efetivação da aprendizagem do estudante [...] E essas capacidades tem a ver com duas grandes dimensões principais. Em primeiro lugar aparece a dimensão cognitiva-acadêmica, na qual se incluem a característica e a quantidade de saberes do docente (formação acadêmica e capacitação contínua), suas estratégias pedagógicas e sua efetividade na transmissão e construção de conhecimentos na coletividade estudantil (VAILLANT; GARCIA, 2012, p. 19).

Constituir-se professor com maior aprimoramento acadêmico pode consistir a princípio, na busca de desempenhar melhor a atividade docente, visando talvez, quem sabe, minimizar as inseguranças e incertezas quanto ao conhecimento de sua atividade profissional. 
Ao analisarmos a questão de gênero, observou-se que há uma expressiva maioria feminina $91 \%$ de mulheres, ou seja, 10 professoras para apenas 01 professor homem (9\%), porcentagens que ratificam a posição de Apple (1995, p.33), quanto ao maior incidência de mulheres nas atividades de docência do que em cargos de direção ou outras atividades, proporcionalmente a quantidade de mulheres presentes no magistério.

\section{Gráfico 7 - Gênero na docência}

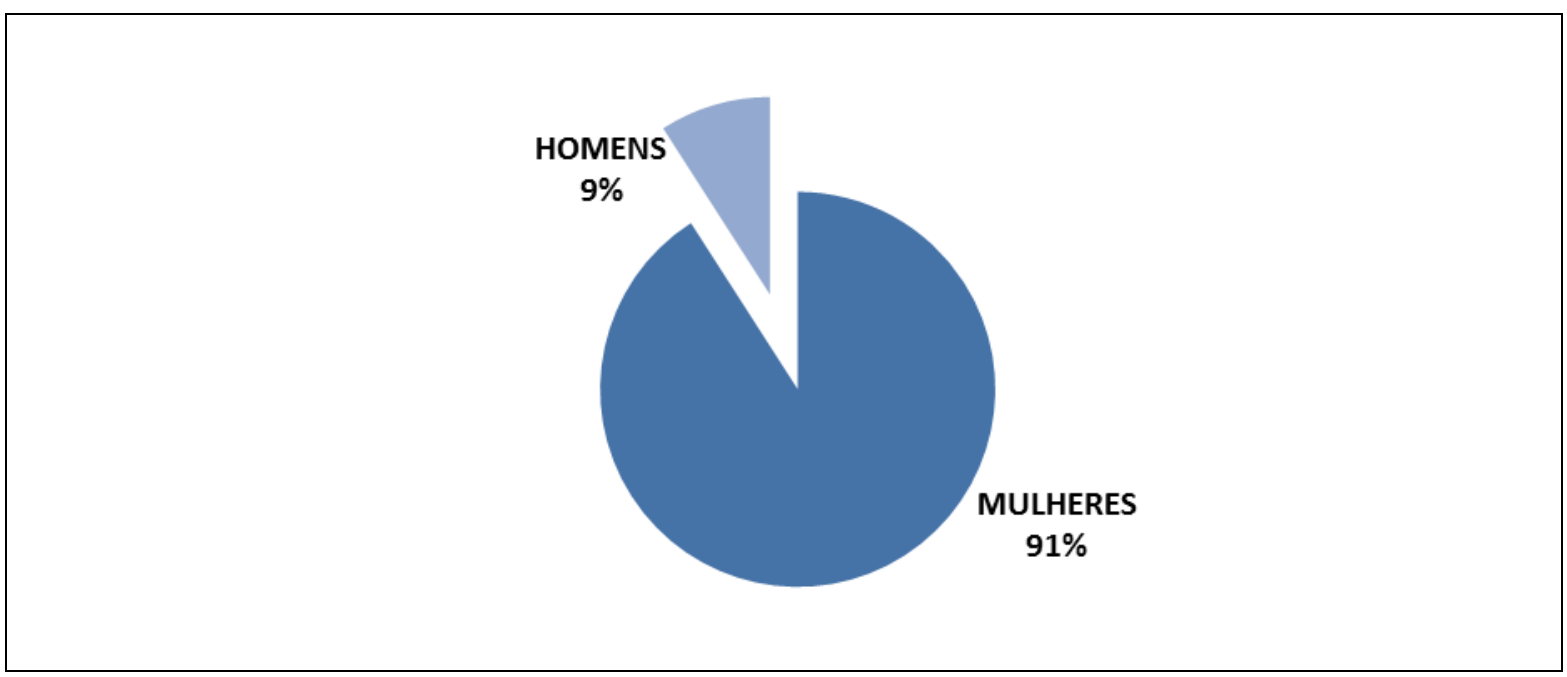

Fonte: Elaborado pela autora da pesquisa com base na questão número 02 do questionário dos professores iniciantes.

A escolha profissional consiste em um momento importante na vida de uma pessoa, carrega múltiplas determinações que vão desde aspectos econômicos e culturais, à identificação com a atividade a ser realizada. Deste modo, a relação que se estabelece com a profissão, estaria diretamente demarcada antes mesmo da efetivação propriamente dita.

A escolha do curso de graduação consiste no primeiro direcionamento dado à carreira e foi considerada em nossa pesquisa. Ao questionar professores iniciantes quanto aos critérios que os levaram à escolha pela docência, obtivemos as seguintes respostas: 
Tabela 1 - Motivo da escolha profissional ${ }^{34}$

\begin{tabular}{l|c|c}
\multicolumn{1}{c|}{ MOTIVO } & RESPOSTAS & $\%$ \\
\hline Acessibilidade ao curso & 5 & 22,73 \\
\hline Identidade com área de conhecimento ensinada & 5 & 22,73 \\
\hline Interesse pela profissão & 4 & 18,18 \\
\hline Vocação & 3 & 13,63 \\
\hline Oferta de Emprego & 2 & 9,09 \\
\hline Questões Financeiras & 2 & 9,09 \\
\hline Gostar de Crianças & 1 & 4,55 \\
\hline
\end{tabular}

Fonte: Elaborado pela autora da pesquisa com base na questão número 12 do questionário dos professores iniciantes.

Como podemos observar, a acessibilidade ao curso e a identidade com a área de conhecimento ensinada, correspondem à $22,73 \%$ respectivamente, como opções de maior incidência entre os professores iniciantes. Diante das respostas apresentadas temos algumas possibilidades de interpretação.

Ao mesmo tempo em que a escolha é tida como interessante do ponto de vista da identidade profissional, a acessibilidade ao curso acaba por configurar uma limitação da escolha, ou seja, uma necessidade objetiva de acesso à universidade.

Essa condição de escolha fundamentada no caminho mais curto de acesso à universidade pode estar ligada a uma série de fatores ocultos ou não mencionados, como: situação econômica, precariedade de formação na educação básica, necessidade de uma certificação, entre outros condicionantes presentes no contexto social deste jovem.

Iniciar uma trajetória profissional pautada em escolhas pouco seguras pode gerar ou abreviar o desinteresse e a desmotivação, passíveis de serem transpostos à profissão, que possui dificuldades próprias e em que

[...] docentes vivem hoje, e desde há muito tempo, uma crise de identidade que se tem visto refletida numa patente situação de mal estar e, mais recentemente, em agudos conflitos em torno de seu estatuto social e ocupacional, dentre os quais a polêmica salarial tem sido apenas a parte visível do iceberg. Nem a categoria nem a sociedade em que estão inseridos conseguem pôr-se de acordo em torno de sua imagem social e menos ainda sobre suas consequências práticas em temos de delimitação de campos de competência, organização da carreira docente, etc (ENGUITA, 1991, p. 41)

\footnotetext{
${ }^{34}$ O professor poderia marcar até duas alternativas.
} 
Assim, observamos que quando questionados quanto à permanência na SEDF apenas 04 professores (36,36\%) tem a convicção de que desejam permanecer, ou seja, 07 professores $(63,64 \%)$ almejam fazer outro concurso público e vislumbram a possibilidade de mudar de profissão, alegando baixos salários, inadequadas condições de trabalho, desgaste emocional e busca por melhor qualidade de vida.

Assim, os condicionantes próprios do indivíduo, as especificidades e precariedades da carreira, a atratividade de outras carreiras presentes no DF, pois congrega vários órgãos da esfera federal e as dificuldades que surgem no início do desenvolvimento profissional docente, combinados, ou não, podem pesar sobre a relação deste professor com a sua profissão e permanência.

Na primeira fase do ciclo profissional docente apontado por Huberman (2000, p.39), as motivações para a permanência ou a saída de uma carreira, não são as mesmas para todos, mas há um perfil homogêneo, que segundo ele se caracterizam em duas fases: a "sobrevivência" e a "descoberta". Uma vez que, o aspecto da

[...] "sobrevivência" traduz o que se chama vulgarmente o "choque do real", com a confrontação inicial com a complexidade da situação profissional: 0 tactear constante, a preocupação consigo próprio ("Estou-me a aguentar?"), a distância entre os ideais e as realidades quotidianas da sala de aula, a fragmentação do trabalho, a dificuldade em fazer face, simultaneamente, à relação pedagógica e à transmissão de conhecimentos, a oscilação em relações demasiado íntimas e demasiado distantes, dificuldades com alunos que criam problemas, com material didático inadequado, etc. Em contrapartida, o aspecto da "descoberta" traduz o entusiasmo inicial, a experimentação, a exaltação por estar, finalmente, em situação de responsabilidade (ter a sua sala de aula, os seus alunos, o seu programa), por se sentir colega num determinado corpo profissional (HUBERMAN, 2000, p. 39).

Huberman (2000) afirma que quando as duas fases são geralmente vividas simultaneamente, as dificuldades da sobrevivência são compensadas pelo entusiasmo das descobertas, mas, contudo, é possível que o professor possa vivenciar aspectos inerentes a apenas uma dessas fases, causando um descompasso nas sensações, Ihe impondo outras características e levando-o à "indiferença ou o quanto-pior-melhor (aqueles que escolhem a profissão a contragosto ou provisoriamente)" (HUBERMAN, 2000, p. 39).

Assim, por se tratar de um momento de exploração e de se estar familiarizando com a carreira numa espécie de compromisso provisório, como o 
próprio autor avalia, temos aqui um quadro consideravelmente preocupante onde 07 (63,64\%) professores estão propensos a desistir da carreira já no período de iniciação e já estariam medindo "as consequências de um comprometimento definitivo com uma profissão que terão procurado com algum desagrado ou na sequência de grandes hesitações" (HUBERMAN, 2000, p. 39).

Aqui, teríamos então, a necessidade de uma efetiva participação dos pares, pois o professor se encontra numa dimensão contraditória de "resistência" e "desistência" ao trabalho docente, precisando fundamentalmente de apoio e boas experiências, para resistir. Embora saibamos que não será somente essa atuação que irá garantir a resistência, visto que outros aspectos influenciam nesta decisão, isso pode amenizar o sofrimento deste profissional e talvez levá-lo a refletir sobre o seu papel e os impactos do seu trabalho sobre a vida de outras pessoas, visto que, a escola consiste em ambiente de trabalho para gestores e professores, institui-se como locus de intencionalidade, que articula projetos de vida e projetos sociais (SEVERINO, 2008), materializando objetivos, desvelando circunstâncias e fomentando sonhos. Em permanente movimento dialético, constrói e é construída através das relações de seus sujeitos ao longo da história. Tanto o professor como o gestor escolar, modificam-na e são por ela modificados na medida em que estabelecem suas relações em seu interior com sua aproximação ao trabalho no desenvolver de suas atividades e na convivência profissional. Portanto,

[...] o trabalho, condição básica para uma existência humanizadora, pode ser igualmente o lugar e a causa da instauração de uma existência degradada, aviltada, totalmente desumanizada, quando as condições de sua realização sejam deterioradas; do mesmo modo, a inserção num grupo social e a necessária sociabilidade pode se transformar num processo de opressão, quando prevalecem às relações de poder e dominação entre as pessoas, seja no âmbito dos pequenos grupos, seja no âmbito dos grandes grupos societais (SEVERINO, 2008, p. 3).

Assim, as relações que os professores iniciantes estabelecem com a carreira e seus pares na fase inicial, pode fazer parte de condicionantes apresentados anteriormente e interferir nas análises que o professor venha a fazer sobre sua permanência ou não, e se considerarmos que "a taxa de redução do número de professores tende a ser mais alta nos primeiros anos da atividade profissional, declinando à medida que se aumenta o tempo de profissão" (OCDE, 2006, p.186), 
teríamos aqui um número significativo de professores em situação de incerteza profissional.

Mas, é interessante observar que 07 professores alegam interesse em sair da carreira $(63,64 \%)$, ao mesmo tempo em que investiram em formação, pois como vimos anteriormente todos (100\%) já possuem cursos de especialização. Teríamos duas questões a fazer e que provavelmente não poderiam ser respondidas por esta pesquisa, mas que devem ser pensadas posteriormente. Essa demora no ingresso foi porque ele tentou outras atividades e não conseguindo, recorrendo a profissão docente como última alternativa? $O$ fato de o professor estar iniciando mais tarde sua carreira, com uma formação mais elevada e com interesse em sair da profissão posteriormente estaria fazendo com que ele visse a docência como algo "provisório"? A possibilidade de outras carreiras, de instância federal presentes no DF, que possuem salários atrativos, pode estar influenciando a decisão quanto à mudança na carreira profissional? Enfim, como sinalizei, tais respostas nos permitiriam outro estudo, mas nos permite fazer também uma terceira análise.

Ao mencionarem o motivo de provável desistência da carreira sinalizaram a condição salarial como primeira justificativa, pois de 07 (100\%) professores pretensos a desistir, $05(71,43 \%)$ mencionaram as palavras: salário, remuneração ou motivos financeiros, como sendo a principal razão de desistência.

\footnotetext{
[...] A desvalorização da carreira acaba levando muitos profissionais a optar pela mudança da área de atuação, em busca de um aumento na renda [...] Tal contexto acaba por gerar, além dos efeitos citados, um sentimento de iniquidade salarial, percebido pelos professores como incompatibilidade entre o salário recebido e o trabalho realizado, agravado pela comparação com outros profissionais da mesma área ou de formação equivalente. O rebaixamento salarial, além do mais, acarreta a limitação do padrão de vida dos professores, acentuando a tendência ao acúmulo de jornadas de trabalho, bem como o "estreitamento das estratégias para lidar com os problemas do cotidiano" (KUENZER, 2009, p. 34).
}

Como consequências desta circunstância, teríamos aqui um problema sem possibilidades de solução por parte do gestor. Conforme vimos, o professor iniciante já chegou à escola interessado em sair, procurar outras esferas de trabalho por alegar problemas com a remuneração, situação que não estaria sobre as possibilidades do gestor resolver, de modo que ao gestor caberia a sua condição de tornar o ambiente agradável, de auxiliar o colega no que for possível e de promover 
a formação e apoio, visando garantir os resultados adequados do trabalho docente. Contudo o professor já está em processo de desistência profissional. Temos aqui uma limitação da capacidade de atuação deste gestor, visto que as interferências realizadas pela condição social de uma categoria estão sendo mais fortes.

A reprodução das condições sociais sobre a perspectiva destes sujeitos em relação ao seu trabalho e profissão, que estariam preocupados com suas condições salariais, almejando outra atividade profissional é coerente, visto que a educação no Brasil não recebe o devido valor, nem em conceito filosófico/cultural, nem em conceito monetário, diante de políticas hegemônicas e contraditórias de manutenção do status quo e de conservação do poder nas mãos de alguns.

A desistência por condições salariais é um exemplo típico das consequências da desvalorização do magistério. A valorização do trabalho docente perpassa aspectos internos e externos à profissão, ou seja,

[...] possui evidentes interfaces com o trabalho e suas condições de produção, mas possui também interfaces muito determinantes com os aspectos anteriores ou externos ao processo de trabalho, tais como formação, políticas de remuneração e carreira, políticas educacionais e, de modo especial, com o prestígio social que é atribuído ao trabalho docente. É uma relação complexa de influências recíprocas em que um fator influencia outros e é por eles influenciado (OLIVEIRA, 2012, p. 215).

O professor iniciante já chega à atividade docente com múltiplos determinantes sociais, que não necessariamente estariam fundados apenas ao universo restrito da escola e sim, sendo determinado por um movimento dialético da totalidade histórica e social da carreira na qual foi submetido e sua constituição enquanto cidadão.

As condições de acesso e permanência na carreira foram carregadas de condicionantes que o colocam em dilemas muitas vezes difíceis de serem amenizados sobre a perspectiva do universo escolar e seus agentes, por uma interface de relacionamento e apoio. 


\subsection{Dialogando com as concepções evidenciadas}

Ao tratarmos com gestores e professores iniciantes a respeito do primeiro contato com a carreira, considerando suas experiências e respectivos papéis na atuação profissional, abordamos questões sobre o ingresso, a aprendizagem docente, as dificuldades e descobertas, a atuação profissional, o relacionamento profissional, atividades e rotinas escolares, ambientalização com o espaço escolar, recepção e acolhimento, que permitiram a evidenciação de quatro categorias que nos ajudam a analisar o objeto, lembrando que todos tem como unidade fundante $o$ trabalho docente, assim, teríamos como eixos de análise a função do gestor, o trabalho escolar, o ingresso profissional e o relacionamento profissional, vejamos:

\footnotetext{
CATEGORIA I - Função do gestor

- A NATUREZa da FUnção do gestor ESCOLAR

CATEGORIA II - Trabalho escolar

- PERSPECTIVAS DAS ATIVIDADES E ROTINAS ESCOLARES

CATEGORIA III - Ingresso profissional

- AS DIMENSÕES DO PROCESSO DE INSERÇÃO NA CARREIRA

CATEGORIA IV - Relacionamento profissional

- MEDIAÇõES INTERATIVAS NO DESENVOLVIMENTO DO TRABALHO DOCENTE

O trabalho, atividade que aproxima e identifica gestores e professores iniciantes, constitui-se na humanização dos homens e aparece de maneira ontológica na vida dos seres humanos, "é condição natural eterna da vida humana, sem depender, portanto, de qualquer forma dessa vida, sendo antes comum a todas as suas formas sociais" (MARX, 1989, p. 208) permitindo dois movimentos essenciais, que os fazem modificar algo e ao mesmo tempo em que os modifica. Esse movimento realizado coletivamente na sociedade a mantém em constante transformação dialética desencadeando condutas e regras sociais.
} 
O trabalho docente possui suas especificidades e se conduz a partir da concepção de educação, sujeitos e de sociedade que temos, portanto insere-se nesse movimento dialético de relações humanas, políticas, econômicas e culturais.

Compreender as percepções que temos sobre nós, o outro e o papel que desempenhamos na sociedade, nos ajuda a interpretar a realidade concreta, as relações que fazemos e a interagir com o mundo que nos cerca.

\subsubsection{A natureza da função do gestor escolar}

Entender a forma como as funções desempenhadas na escola são assimiladas pelos sujeitos ajuda a explicar como estes constroem suas relações em seu interior, revelando sua dinâmica, objetivos, processos e resultados, desvelando a realidade apresentada.

A natureza de uma função no sentido de particularidades e características essenciais pode ser percebida de diferentes formas a considerar o ponto de vista que cada um sobre o objeto em questão. Cada membro presente na comunidade escolar pode perceber a função do gestor de uma forma diferenciada, ou também, ao contrário, todos podem ter uma visão convergente a respeito.

De acordo com a interpretação teremos posturas, ações e cobranças distintas em relação à pessoa que esteja imbuída da responsabilidade legitimada pela função. Desta maneira, a função do gestor escolar é por vezes objeto de discordância quanto à realização das tarefas, que dicotomizadas entre administrativo e pedagógico, acaba sendo mal interpretada quando carrega características e exigências próprias dentro da dinâmica escolar.

Embora saibamos que a escola tem um conjunto de elementos articulados e que é no todo que está a sua importância e grandeza, a atuação do gestor nos processos educacionais sempre foi analisada e questionada quando dos resultados apresentados por suas instituições, tendo um caráter da personificação e/ou responsabilização legal, onde

[...] a valorização do diretor de escola segue paralela à valorização da administração no ensino básico, já que ele é considerado o responsável último pela administração escolar. Quer como aquele que coordena (e controla) o trabalho de todos, quer como líder que estimulam subordinados 
e comanda a proposição e o alcance de metas, o diretor é considerado por todos como elemento mais importante na administração da escola (PARO, 2015, p.20).

Assim, seu papel, sua função, está sempre ligado a conceitos administrativos que tendem a serem concebidos pelo viés dado das empresas capitalistas do mundo contemporâneo globalizado, que o obrigam a seguir critérios que muito se assemelham à cadeia de produção capitalista, onde o aluno seria um cliente.

Contudo, sabe-se que

[...] a administração é sempre utilização racional de recursos para realizar fins, independentemente da natureza da coisa administrada: por isso é que podemos falar em administração industrial, administração pública, administração privada, administração hospitalar, administração escolar, e assim por diante (PARO, 2015, p.18)

E, desse modo

[...] não há nada de errado em se exigir que a escola seja produtiva, desde que a medida de sua produtividade se refira ao produto que the cumpre oferecer: o aluno educado, ou melhor, a porção de cultura incorporada à personalidade do aluno pela ação da escola (PARO, 2015, p. 75)

O papel do gestor the encarrega de mediar um conjunto de elementos (financeiros, humanos, materiais, pedagógicas...) junto aos interesses institucionais que envolvem alunos, pais e professores.

A função do gestor escolar foi associada pelos respectivos sujeitos, que trataremos por "G" para Gestores (G1, G2, G3, G4 e G5) e "P" para Professores (P1, P2, P3, P4 e P5), de diversas maneiras. Ao definirem a função usaram palavras como: mediar, organizar, dirigir, diretrizes, conflitos, problemas, rotinas, ideias, processos, direção, diretriz, articulação, gerenciamento, qualidade de ensino, formação, conciliar, complexo, saber de tudo, resolver, entre outras, que foram quantificadas e agrupadas de acordo com o contexto mencionado.

Assim, as visões dos sujeitos a respeito, apresentadas na entrevista, permitiram identificar cinco perspectivas, que indicam o seguinte entendimento da função: 
1. Harmonizadora - Entendimento de que a função estaria atrelada mediação de conflitos, resolução de problemas, compatibilização de rotinas, ideias, concepções, projetos de interesse coletivo.

2. Administrativa - Estaria atrelada à ideia de condução, direcionamento, articulação, gerenciamento e procedimentos técnicos de cunho organizacional-burocrático.

3. Pedagógica - Ligado às concepções que, voltadas para a garantia da qualidade de ensino, dos processos de estudo e formação dos sujeitos de modo geral.

4. Representativa - Configura um entendimento de autoridade e representação da unidade escolar diante do grupo e de outras instituições ou esferas.

5. Complexa - Tem por premissa uma visão global da função, envolvendo as perspectivas anteriores, dando-lhe 0 entendimento múltiplo. Atribui à função aspectos administrativos/burocráticos, didático-pedagógicas, financeiros, representativos e legislativos, que integra todo o universo escolar de pais, alunos, professores, servidores, enfim a comunidade escolar como um todo e em tudo que a ela disser respeito.

A perspectiva harmonizadora se destaca mais para os professores $(45,83 \%)$, que para os gestores $(39,22 \%)$, em termos percentuais, mas para ambos ocupa 0 topo caracterizando-se como a principal função do gestor. Enquanto que para professores a perspectiva representativa surgiu como elemento da função, para os gestores ela se constituiu nula.

A perspectiva pedagógica não se destaca nem para professores $(4,17 \%)$, nem para gestores $(9,80 \%)$ embora sendo mais presente na fala dos gestores. Já a perspectiva administrativa aparece igualmente referida por ambos os sujeitos $(37 \%)$. Vejamos a tabela: 
Tabela 2 - Perspectivas da função do gestor escolar

\begin{tabular}{l|c|c|c|c}
\multicolumn{1}{c|}{ MOTIVO } & Gestores & $\%$ & Professores & $\%$ \\
\hline Harmonizadora & 20 & 39,22 & 11 & 45,83 \\
\hline Administrativa & 19 & 37,25 & 9 & 37,50 \\
\hline Representativa & 0 & 0 & 2 & 8.33 \\
\hline Pedagógica & 5 & 9,80 & 1 & 4.17 \\
\hline Complexa & 7 & 13,73 & 1 & 4.17 \\
\hline
\end{tabular}

Fonte: Elaborado pela autora da pesquisa de acordo com a incidência de palavras que remetem à perspectiva tratadas nas entrevistas.

Para a perspectiva harmonizadora, as ações do gestor estariam ligadas às necessidades imediatas, que tratam de soluções rápidas e corriqueiras. Vejamos algumas falas:

"Sua função é mediar conflitos, tanto com pais, quanto com alunos, quanto com os colegas [...] Assim, eu trabalho muito a questão da humanização." (G3)

"Ele tem que ter uma postura firme, mas ao mesmo tempo uma postura de liderança e liderança não no sentido de mandar, mas no sentido de demonstrar lidar, com as relações, principalmente na sociedade que nós estamos hoje, de articular as ideias de planejar junto com os professores, de ter um olhar sensível pelo outro, esse outro sujeito, seja o aluno, seja o professor, seja o coordenador, seja pai de alunos, seja um servidor da limpeza. Então ele tem que ter esse olhar sensível." (P4)

"A função da gestão escolar é organizar o funcionamento da escola." (P3)

Como se observa nas falas a perspectiva é no sentido do acordo, da coerência, do equilíbrio e da organização do espaço escolar. Libâneo (2001, p. 33) nos lembra de que,

[...] a cultura da escola (ou cultura organizacional) é o que sistematiza os sentidos que as pessoas dão às coisas, gerando um padrão coletivo de pensar e perceber as coisas e de agir. [...] as práticas e os comportamentos das pessoas, manifestos na convivência diária influenciam as práticas e comportamentos dos professores nas salas de aula.

A convivência cotidiana gera conflitos, divergências, as pessoas pensam diferentemente e querem coisas distintas, saber estabelecer o diálogo em busca do bem-estar comum é superar obstáculos e discordâncias na construção de um 
propósito coletivo. É fundamental que o gestor saiba estabelecer essa relação, pois quando

[...] há divergências entre os interesses dos trabalhadores e os objetivos a se realizarem, a coordenação ganha um caráter marcadamente político, tornando-se muito mais complexas suas funções e as formas de empregar o esforço humano coletivo. Ela não prescinde dos elementos técnicos, mas de ocupar-se mais intensamente dos interesses de conflito (PARO, 2015, p.34).

Assim, por um lado essa característica harmonizadora não contempla a função, ao passo que ela em si mesma retira do gestor o caráter técnico necessário à adequação de meios e fins, que superam em muito essa condição corriqueira do dia-a-dia e se vincula a qualidades e atributos pessoais. "O dimensionamento da prática administrativa do diretor escolar se fundamenta, incialmente, na necessidade de se conceber maneiras de o diretor contribuir para uma maior competência administrativa da escola" (PARO, 2015, p.46) e não somente harmonizar a unidade escolar.

A habilidade harmonizadora certamente caminha para o sentido da gestão democrática da escola, princípio preconizado na constituição e nas legislações que versam sobre a educação no Brasil e no Distrito Federal. Tal princípio implica a capacidade de discutir, elaborar e aceitar regras coletivamente, mas a superação de obstáculos e divergências, por meio do diálogo, para a construção de propósitos comuns, não necessariamente constitui-se no completo atributo da função.

Na segunda perspectiva, a administrativa, a função do gestor escolar estaria ligada a habilidades técnicas/burocráticas e de gerenciamento de processos.

Por ter a escola pública a finalidade de atendimento ao cidadão em seu direito essencial de acesso à educação, suas unidades não funcionam isoladamente, necessitando de meios para manter sua estrutura física e seus recursos materiais e humanos. Num conjunto de normas que regem todas as suas atividades e funções integradas a um sistema de administração pública. Deste modo, existe uma série de mecanismos inerentes ao seu funcionamento que usualmente são chamados de administrativos e burocráticos.

Considerando as análises sobre a fala dos sujeitos, teríamos como função do gestor escolar, nesta perspectiva, o atendimento a essa necessidade de lidar com 
mecanismos de sustentabilidade organizacional da escola. O gestor teria por função estabelecer condutas no sentido de conduzir, direcionar, coordenar, organizar a escola, dar diretrizes de funcionamento, otimizando recursos e pessoas na administração de rotinas, ideias e processos, orientando e encaminhando o grupo em suas atividades de modo geral.

Vejamos como se estabelecem essas concepções nos discursos dos sujeitos:

\begin{abstract}
"Conduzir, conduzir processos educacionais, quem vai direcionar, não é quem vai dizer como é, mais ele direciona, ele vai ouvir todo mundo, mas vai dar o tom, vai dizer é esse o objetivo que nós temos, então nós vamos seguir por aqui." (G4)

"A gente tem que trabalhar com as leis, com a legislação, tudo dentro do correto." (G3)

"Ele está ali na frente de todo o processo, então o papel dele é muito importante na escola, por que é ele que dará as diretrizes pra gente, assim as diretrizes que eu falo é no sentido de como a escola anda." (P1)
\end{abstract}

Cada vez mais, se busca ampliar a perspectiva de autonomia das escolas, o que pode ser encarado como uma descentralização de tarefas, ou também, transferência por parte do governo de responsabilidade sobre os processos administrativos, assim Ihes conferindo maior autoridade e responsabilidade. Isso, por sua vez, exige mais técnica, responsabilidade e compromisso, com o bem público, como também pode provocar a intensificação do trabalho do gestor, visto que sua atuação não se limita a determinada atividade, pelo contrário, abrange todo o leque de atividades que envolvem outras instâncias escolares.

[...] Não se trata de opor "educador preocupado com o bem-estar dos alunos" e o "administrador em busca da eficiência". Quando se dá a primeira ocorrência, necessariamente está se dando a segunda. Ser educador é a forma de buscar a eficiência escolar. Não é possível buscar a eficiência na escola se não se estiver preocupado (envolvido) com o bem estar dos alunos (PARO, 2015, p. 27).

Mas existe nas escolas uma dicotomia muito presente entre atividade administrativa e atividade pedagógica, que fazem com que seus agentes se intitulem conforme a posição que lhes é conveniente. Vejamos o que disseram os sujeitos entrevistados: 
"Eu não sou uma diretora administrativa, eu tenho um trabalho mais voltado para o pedagógico." (G2)

"Nós temos dentro de escolas hoje, diretores que se dizem administrativos e temos diretores que estão mais envolvidos com o pedagógico, então isso é muito comum, eu não me apego a essa questão não. Eu sinto assim, eu percebo nas escolas, às vezes em conversas com colegas que essa diferenciação ela existe, um diretor que se diz administrativo ou pedagógico e um vice que se diz... ou que é pedagógico. Por que na verdade é muita coisa, é muita coisa pra gente fazer". (G5)

Segundo vimos nas falas apresentadas essa ambiguidade no entendimento da função faz com que gestores deleguem parte de suas funções a outros membros da equipe escolar como o vice-diretor, supervisores ou coordenadores. Essa dicotomia do trabalho não é coerente, pois

[...] o processo de trabalho pedagógico está perpassado pelo técnico e pelo político em completa simbiose. Toda providência técnica consiste então, no provimento e fortalecimento da ação política (democrática), de tal forma que quanto mais tecnicamente consistente, mais o processo se torna democrático e quanto mais democrático mais se fortalece tecnicamente (PARO, 2015, p.66)

Assim, o constructo administrativo não se configura como único elemento a estar presente nas atividades do gestor visto que, "construir uma escola democrática hoje, significa assegurar as condições pedagógicas e organizacionais para se alcançar mais qualidade cognitiva das aprendizagens" (LIBÂNEO, 2001, p. 9).

É possível desenvolver atividades pedagógicas ao mesmo tempo em que se aplicam os procedimentos técnicos administrativos colocando sua função à disposição de um todo escolar. De fato, é muito oportuno que o gestor pense em estratégias e em atividades específicas da função social da escola, que possam coincidir com as atividades relativas a outros elementos sociais presentes no contexto escolar. Procedendo assim, o gestor simplifica as decisões em torno da sobreposição de tempos e espaços para o desenvolvimento das atividades de uma ou outra instância e também possibilita maior racionalidade do seu trabalho.

Caminhando rumo ao terceiro aspecto, temos o pedagógico, uma perspectiva voltada para os processos de ensino e formação. Nesta concepção, o gestor escolar teria como função as preocupações que envolvam os processos de 
ensino e aprendizagem de modo geral, garantindo ensino de qualidade e, portanto uma preocupação maior com a qualidade de formação própria e coletiva. Vejamos:

"A função dele é garantir ao aluno ensino de qualidade, a função primordial seria essa." (G1)

"Trabalhar com os projetos que melhorem o ensino e as questões pedagógicas da escola, relacionadas mesmo ao conteúdo em sala de aula, o conteúdo dos alunos." (P3)

Essa preocupação mencionada por gestores e professores, vai de encontro a função primordial da escola, ao direito preconizado pelos seus objetivos e fins a que se dedica, por isso, a preocupação com os seus resultados na aprendizagem dos alunos, intensificando o foco da gestão nas questões pedagógicas em detrimento das administrativas. Libâneo (2004, p.16) afirma que essa dicotomia não existe ou, pelo menos, não deveria, visto que o ambiente escolar já é por si um ambiente de aprendizagem e tudo que for estabelecido estaria em função disso, pois

[...] não é possível a escola atingir seus objetivos e sua proposta curricular sem formas de organização e gestão [...] e que há uma íntima relação entre o que acontece no contexto da organização escolar e o que acontece na sala de aula, pelo fato de que as práticas de gestão são práticas educativas e de que a escola é um espaço de aprendizagem e formação profissional.

Portanto, Paro (2015, p. 46) complementa essa declaração afirmando sua atenção à necessidade de se adequar os meios aos fins e alega que

[...] o dimensionamento da prática administrativa do diretor escolar se fundamenta, inicialmente, na necessidade de se conceberem maneiras de o diretor contribuir para uma maior competência administrativa da escola fundamental. Isso é relevante porque a escola brasileira, de modo geral, não logra alcançar minimamente os objetivos a que se propõe. É de conhecimento público que, salvo exceções, as escolas fundamentais no país não conseguem "passar" à imensa maioria de seus frequentadores sequer os mínimos rudimentos de conhecimentos e informações que são objeto das "avaliações" externas feitas pelos sistemas de ensino. $E$ isso ao custo de pelo menos oito anos de dispêndio em recursos tanto objetivos quanto subjetivos. Em termos administrativos, isso equivale a um fracasso no empreendimento escolar, visto que os recursos, ou sua utilização, ou ambos os fatores, não estão adequados ao objetivo estabelecido. Trata-se, portanto, da negação do princípio fundamental da boa administração que requer a adequação entre meios e fins. (PARO, 2015, p. 46) 
Essa discussão e preocupação com as dimensões pedagógicas da função não caracterizam a única demanda do gestor, embora se constitua em um elemento fundamental. Assim, compreender o posicionamento da escola no sistema de ensino, dominar os princípios da administração pública, compreender as fontes de financiamento da educação pública com a qual se trabalha, bem como as situações práticas do dia-a-dia dentro da instituição, também possuem sua relevância, não devendo ser desprezados.

Esses elementos se constituem fundamentais para o desenvolvimento de um trabalho pedagógico, coletivo e coerente. A escola precisa organizar espaços físicos que favoreçam o trabalho, horários e estruturas que possibilitem as atividades, promovendo regularmente encontros com os docentes para o alcance dos resultados esperados, motivá-los e ouvi-los, cuidar do patrimônio, providenciar recursos para o bom andamento das atividades, enfim, para viabilizar a execução das tarefas pedagógicas, decisões e procedimentos administrativos devem ser concebidos, de modo que a inviabilização de um trará consequências ao outro.

A respeito deste assunto a gestora (G5) entrevistada exemplificou bem a questão, vejamos:

"Porque assim, por exemplo, por que quando eu administro um abono de um professor, isso é administrativo, mais se eu na verdade preciso pensar no que ele ia fazer e eu preciso pensar em alguém que pode fazer isso por ele, no caso de uma substituição, a questão é pedagógica". (G5)

Deste modo, a

[...] escola é uma organização complexa, composta por pessoas e pelas suas interações, na qual se leva a cabo uma tarefa plena de valores e ética que não pode ser realizada de modo mecânico dado que são as interações e os processos de negociação social das pessoas que fazem a escola [...] os próprios modos de organização e os processos de gestão não deverão apresentar-se somente enquanto meios para o desenvolvimento da ação pedagógica, mas constituírem-se eles próprios como objetos de ação pedagógica (COSTA; CASTANHEIRA, 2015, p. 26)

Outra perspectiva que emergiu, reporta ao caráter simbólico representativo do gestor escolar, enquanto líder.

"Querendo ou não, é como se eles representassem o governo, como se eles representassem a maior autoridade dentro da escola". (P5) 
Do ponto de vista de Paro (2015, p.42),

[...] pode até acontecer de os estabelecimentos de ensino comportarem em sua organização conselhos de escolas ou outras instituições auxiliares da gestão - com atribuições deliberativas ou não - mas quem responde, em última instância, pelo cumprimento das leis do ensino e pela ordem no âmbito da escola (ou seja, pelo funcionamento da empresa escola) é o diretor. [...] Investido na direção, ele concentra um poder que lhe cabe como funcionário do Estado, que espera dele o cumprimento de condutas administrativas.

É importante ressaltar que este poder investido pelo Estado e pela comunidade, por meio de processo eletivo, the confere a priori a representatividade, não lhe concede atributos de liderança exigidos para o seu trabalho. A conquista da confiança dos colegas, colaboradores e subordinados no exercício de convergir ideias em prol do bem comum, requer muito mais que investidura da autoridade no cargo.

Quando os líderes são eleitos diretamente pelos pares se beneficiam da proximidade que possuem com a comunidade escolar tendo em vista a credibilidade depositada, mas

[...] é importante assinalar que a liderança não é atributo exclusivo de diretores e coordenadores, nem está ligada a apenas ao cargo e ao status da pessoa [...] Entretanto não se pode negar que, mesmo na gestão democrática efetivada de forma cooperativa e participativa, o funcionamento e a eficácia da escola dependem em boa parte da capacidade de liderança de quem está exercendo a direção e a coordenação pedagógica (LIBÂNEO, 2004, p. 104).

Portanto, teríamos uma diferença básica entre liderança e gestão, de modo que "líderes influenciam o compromisso para com a organização, enquanto os gestores agem de acordo com as responsabilidades decorrentes da sua posição e exercem autoridade sobre os subordinados" (COSTA; CASTANHEIRA, 2015, p.28). Com este entendimento acredita-se que o gestor deva ser também um líder e para tanto requer conhecimentos que Libâneo $(2004$, p.35) descreve de dois modos:

[...] As qualificações referem-se à aquisição de saberes requeridos para o exercício de uma profissão e à confirmação legal dessa aquisição mediante diplomas, certificados etc. As competências referem-se a conhecimentos, habilidades e atitudes obtidas nas situações de trabalho, no confronto de experiências, no contexto do exercício profissional. A competência profissional é a qualificação em ação. 
Assim, o gestor deve reunir junto à sua posição representativa, os seguintes saberes e competências:

- Elaboração e execução do planejamento escolar: projeto pedagógico-curricular, planos de ensino, planos de aula.

- Organização e distribuição do espaço físico, qualidade e adequação dos equipamentos da escola e das demais condições materiais e didáticas.

- Estrutura organizacional e normas regimentais e disciplinares.

- Habilidades de participação e intervenção em reuniões de professores, conselho de classe, encontros, e em outras ações de formação continuada no trabalho.

- Atitudes necessárias à participação solidária e responsável na gestão da escola como cooperação, solidariedade, responsabilidade, respeito mútuo, diálogo.

- Habilidades para obter informações em várias fontes, inclusive nos meios de comunicação e informática.

- Elaboração e desenvolvimento de projetos de investigação.

- Princípios e práticas de avaliação institucional e avaliação da aprendizagem dos alunos.

- Noções sobre financiamento da educação e controles contábeis, assim como formas de participação na utilização e controle dos recursos financeiros recebidos pela escola. (LIBÂNEO, 2004, p.37)

Finalizando, temos a perspectiva complexa, em que a função do gestor escolar constitui-se na compreensão e articulação de um todo, atuando em várias dimensões e perspectivas. $\mathrm{O}$ trabalho envolveria aspectos administrativos/burocráticos, didático-pedagógicas, financeiros, representativos e legislativos integrando o universo escolar de pais, alunos, professores, servidores, enfim a comunidade escolar como um todo, e em tudo, que a ela disser respeito, promovendo as mediações técnico/administrativas entre meios e fins.

Para que a escola possa ser capaz de promover tanto o desenvolvimento de aprendizagens, quanto os de processos, ela necessita estar organizada como um conjunto e para isso seus objetivos e esforços coletivos devem convergir no mesmo sentido, equacionando diversos elementos. Isso, por sua vez, exige vários conhecimentos envolvendo todas as perspectivas harmonizadora, administrativa, pedagógica e representativa. 
As visões apresentadas pelos sujeitos sobre a função do gestor trazem nas falas o entendimento de que deva haver essa composição na função do gestor. Vejamos:

\begin{abstract}
"Porque o papel do gestor na escola é justamente agir com relação à democratização das relações, a democratização das tomadas de decisões dentro da escola e para a escola, incluindo todos, incluindo toda a comunidade escolar, alunos, professores, pais, todos eles." (P4)

"Ele administra a escola dentro de muitas perspectivas pedagógicas, administrativas e outra que hoje já não tem tanta dificuldade, já houve mais dificuldades que é a financeira... e administrar várias ideias, várias formas de pensar e no final de tudo ele tem que ouvir, ouvir, ouvir, ler e depois que ele colhe no final de tudo ele tem que fazer com que aquilo ' $x$ ', que as vezes num foi a ideia de um, num foi só a ideia do outro, se torne uma ação coletiva que será boa para todos, então isso faz parte do nosso trabalho." (G5)
\end{abstract}

Observa-se que a função do gestor escolar supõe uma administração complexa e com vários determinantes a serem mediados para a realização dos fins.

Conforme já tratamos anteriormente o parágrafo único do artigo 67 da LDBN 9.394/96, exige a experiência docente para o exercício profissional de quaisquer outras funções de magistério, incluindo-se ai, a gestão escolar. Com isso o gestor é antes de tudo um educador, portanto,

[...] a ação da escola e de seus educadores reveste-se assim de uma complexidade ímpar que exige condições de trabalho adequadas tanto aos aspectos políticos quanto aos técnicos. Os primeiros dizem respeito, acima de tudo, à liberdade e à autonomia de professores e demais educadores escolares, para planejarem e organizarem suas atividades de acordo com as peculiaridades de seus alunos, do currículo envolvido e da especificidade do trabalho pedagógico. Os aspectos técnicos, por sua vez, têm a ver com todas as condições materiais e institucionais necessárias ao desenvolvimento da ação pedagógica, indo desde recursos didáticos, material escolar, mobiliário, salas e ambientes disponíveis, passando por remuneração satisfatória e formação permanente adequada, até os espaços e tempos reservados para a troca de experiências com colegas de trabalho e compartilhamento de experiências com a comunidade (PARO, 2015, p.67).

Libâneo (2001) também afirma que dirigir uma escola "é pôr em ação, de forma integrada e articulada, todos os elementos do processo organizacional (planejamento, organização, avaliação), envolvendo atividades de mobilização, liderança, motivação, comunicação e coordenação". (p. 179). 
Garantir o funcionamento de um espaço complexo como a escola, exige uma reflexão e ação ainda mais complexa sobre sua estrutura e práticas desenvolvidas, portanto, a habilidade do gestor terá que constituir-se no sentido de garantir os processos pedagógicos e técnicos/administrativos, harmonizando o seu contexto e representando-o.

Assim, o apropriado entendimento da função do gestor seria no sentido da perspectiva complexa, mas em meio à luta de classes presente na sociedade e suas múltiplas determinações políticas, econômicas e sociais há ingerências e influências sobre a função, que the confere atribuições de acordo com interesses diversos, acabam por ocasionar a sobreposição de uma perspectiva sobre a outra.

Deste modo, quando os interesses econômicos dominam os discursos, a busca pela "produtividade escolar" desconsidera o sujeito e suas relações com os processos educativos, produzindo rankings e vinculando recursos às unidades de ensino de maneira meritocrática, dando um caráter "distorcido" aos processos técnicos/administrativos, fazendo com que estes se sobressaiam sobre os humanos e pedagógicos. Por outro lado, em virtude das demandas cotidianas determinadas pela rotina diária que reproduzem desigualdades sociais, culturais, econômicas e políticas, tornando o espaço escolar plural e conflituoso, podem levar o gestor a se ocupar apenas da perspectiva harmonizadora, o que também permitiria a sobreposição dos aspectos administrativos em detrimento dos pedagógicos.

Portanto, cabe ao gestor escolar se ancorar numa constante reflexão a respeito de sua atuação, não se desvinculando da perspectiva complexa da função visando garantir o equilíbrio nas ações e o devido andamento da instituição escolar rumo à sua função social.

\subsubsection{Perspectivas das atividades e rotinas escolares}

Considerando a discussão anterior sobre as perspectivas da função do gestor, buscaremos agora compreender na rotina escolar a distinção e relação feitas pelos sujeitos quanto às atividades pedagógicas e administrativas desenvolvidas na dinâmica escolar. 
Perguntamos aos entrevistados, professores e gestores: $O$ que você caracterizaria como sendo atividade administrativa e atividade pedagógica e o que você pensa da relação entre elas? E aos gestores pedimos ainda, que comentassem suas rotinas diárias, exemplificando as atividades que faziam diariamente em seu trabalho.

Assim, às atividades administrativas foram identificadas pelas seguintes expressões: prévia de pagamento, folhas de ponto, transporte escolar, verba/financeiro, atestados médicos, diário de classe, funcionários terceirizados, abonos, folgas concedidas por órgão públicos ${ }^{35}$, compras de material para a escola, reuniões (internas e externas), matrícula, transferência e renovação de alunos, rotina da secretaria, reformas e manutenções, patrimônio, provas, lanches, modulações, conflitos, cumprimento de horários, contratação de professores, abertura de turnos escolares, vida funcional de funcionários e entre outras demandas que dizem respeito ao trabalho deles.

Já as atividades pedagógicas foram mencionadas nos seguintes termos: Projetos escolares, coordenações coletivas, planejamento, controle disciplinar, aprendizagem, diagnósticos, atendimentos psicológicos, formação continuada, substituição de professores, currículo, reuniões, atividades da sala de aula, função social da escola, organização do trabalho pedagógico, saídas de campo, avaliação, festividades e eventos.

Ao justificar a categorização das tarefas desempenhadas, os professores declaram que:

\begin{abstract}
"A atividade administrativa eu acredito que seja mais voltada para a parte burocrática, da questão da papelada e a parte pedagógica é o nosso dia-adia com o aluno, os dois tem ligação, sim, tem, por que a parte pedagógica ela não funciona independente da parte administrativa, por que as vezes tem que tá sempre fazendo registros, e ai essa parte do registro ele está na parte pedagógica mais ele se caracteriza como algo administrativo, por que a gente precisa está sempre registrando tudo, é o nosso diário, é o relatório do aluno. E a gente também precisa dessa documentação pra tá embasado, pra simplesmente num dizer ele está assim só de palavras, a gente precisa do registro ali também". (P1)
\end{abstract}

${ }^{35}$ Conhecidas como folgas de TRE (Tribunal Regional Eleitoral), são concedidas ao funcionário que trabalha no processo eleitoral podendo ser usufruídas conforme o interesse do funcionário. 
"A atividade administrativa, ela está relacionada mais a essa questão do cumprimento de horários, do cumprimento da carga horária de trabalho, da chegada e saída da escola, acho que está mais relacionado a isso o administrativo. E o pedagógico ele tá relacionado a tudo que envolve a função social da escola, por exemplo, a questão do ensino em si, do currículo, a questão dos valores éticos, a questão da organização do trabalho pedagógico na escola, a saída de campo, as festividades da escola, a relação dos professores com os alunos, dos pais com a escola, então o pedagógico ele está voltado pra isso". (P4)

$\mathrm{Na}$ análise do conjunto das falas identificamos que o administrativo aparece respectivamente com maior frequência em relação às atividades pedagógicas. Embora haja uma identificação pontual, 03 gestores (60\%) e 04 professores (57\%) dizem não haver como separar uma da outra, ambas trabalham juntas e, por estarem vinculadas no dia-a-dia, têm reciprocamente sua importância na obtenção dos resultados escolares.

"Não tem como a gente andar só com um seguimento, sem depender do outro. [...] São coisas distintas, mas que uma só funciona em detrimento da outra". (G1)

"De certa forma se o administrativo não tiver bem organizado, o pedagógico fica com dificuldade de andar, o pedagógico depende de um administrativo bem organizado, se não tiver, ai você vai se enrolar nas duas coisas. [...] Então se eu não tiver essa relação perfeita entre o pedagógico e administrativo, fica difícil gerenciar uma escola". (G2)

Pontuando distintamente cada atividade gestores e professores apresentaram mais tarefas de cunho administrativo. Vejamos como se comportou essa incidência no gráfico:

\section{Gráfico 8 - Atividades administrativas e pedagógicas}

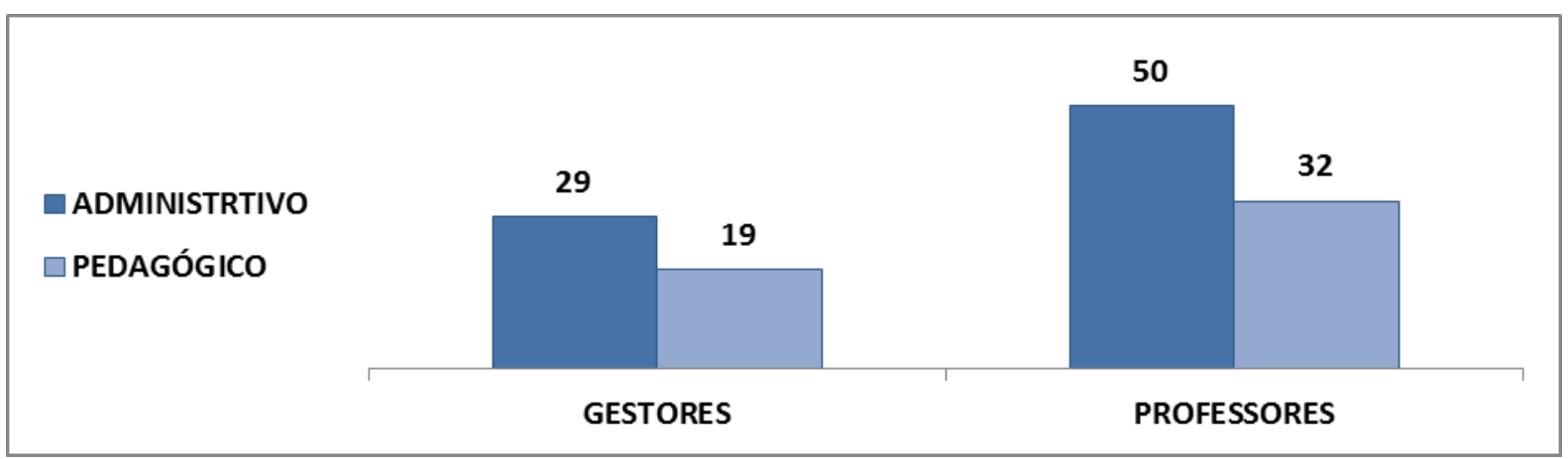

Fonte: Elaborado pela autora da pesquisa de acordo com a na incidência de palavras que remetem à atividade tratadas nas entrevistas. 
Deste modo, para os dois grupos de sujeitos, as atividades administrativas se destacaram em volume de repetições, em relação às pedagógicas, considerando a proporcionalidade entre professores e gestores.

Embora o foco escolar seja o pedagógico e, portanto, o processo de formação dos sujeitos, as atividades administrativas foram mais mencionadas, ou porque são mais fáceis de serem percebidas e pontuadas, ou por estarem mais frequentes no contexto da escola, ou por outros motivos, fato é que foram mais quantificadas.

No capítulo VII do Regimento Escolar da SEDF que trata do planejamento, do controle e da avaliação das atividades o artigo 56 inciso IX que versa sobre a proposta pedagógica das unidades escolares, indicando a necessidade de se contemplar na gestão aspectos administrativos e pedagógicos, ou seja, a ação administrativa se constitui em uma ação pedagógica dada a função e o caráter educativo da escola, caminhando para uma visão híbrida entre estes elementos.

Libâneo (2004) contribui esclarecendo que o "que se deve evitar é a redução da estrutura organizacional a uma concepção estritamente funcional e hierarquizada de gestão subordinando o pedagógico ao administrativo" (p. 207).

Assim, a vigilância frequente, já apontada por Paro (2015), entre à correta articulação dos meios aos fins, tenta garantir que um elemento não se sobreponha sobre o outro, evitando a perda do foco na função social à qual a escola está vinculada.

Os gestores elencaram realizar em suas rotinas diárias as seguintes demandas:

Tabela 3 - Atividades desenvolvidas pelos gestores escolares

\begin{tabular}{l|c|c}
\hline \multicolumn{1}{c|}{ ATIVIDADES } & INCIDÊNCIA & $\%$ \\
\hline Internas & 32 & 71,11 \\
\hline Externas & 8 & 17,78 \\
\hline Manutenção & 5 & 11,11 \\
\hline
\end{tabular}

Fonte: Elaborado pela autora da pesquisa de acordo com a incidência de palavras que remetem à atividade tratadas nas entrevistas.

As atividades internas $(71,11 \%)$ compõem-se de reuniões (setoriais), rotinas diárias (abertura e fechamento de turno, assessoramento aos vários segmentos, 
supervisão e vistoria), atendimentos (pais, alunos, professores, funcionários, comunidade etc.) e organização (eventos, calendário escolar, reuniões, passeios etc.). Já as atividades externas (17,78\%) seriam reuniões (CRE, demais escolas e outras instituições), execução de verba (compras, banco, contador) e tramitação de documentos. No que tange a manutenção $(11,11 \%)$ seria os reparos, consertos e instalações.

Dentre as várias atividades realizadas, o atendimento à comunidade em geral e as rotinas diárias se destacam como sendo as atividades mais realizadas pelos gestores escolares. Vejamos as incidências das atividades:

\section{Gráfico 9 - Incidência de atividades do gestor}

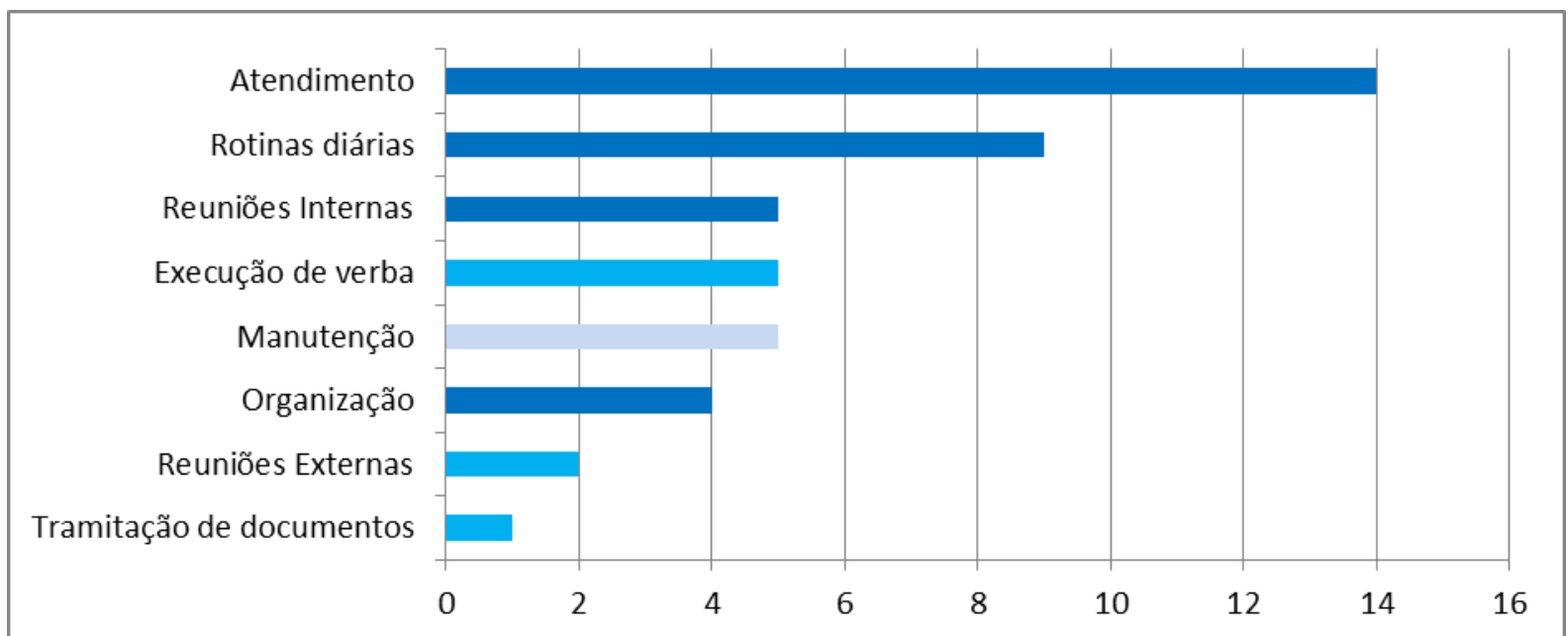

Fonte: Elaborado pela autora da pesquisa de acordo com a incidência de palavras que remetem às atividades tratadas nas entrevistas.

A maior parte das atividades dos gestores estaria nos atendimentos à comunidade e nas rotinas diárias, conforme relatam:

"Olha, aqui na escola eu chego às 6 h30 da manhã, porque eu chego antes dos meus alunos, vejo se está tudo certo, se as salas foram higienizadas, os servidores chegam às $6 h$ da manhã. Então quando eu chego às $6 h 30$ eles já estão aqui, o turno começa às $7 h 10$ e 6h30, 6 h20 eu já estou na escola pra saber se está tudo certo. Quando é umas 10 para às $7 h 0$ professores começam a chegar, até as minhas coordenadoras chegarem pra saber se os professores estão chegando, se tem algum professor que está de atestado, se não vai comparecer naquele dia, se a equipe da cozinha tá na escola, e ai 7h10 começa a entrada dos meninos já pra sala de aula, por que a entrada deles no portão começa 7 h da manhã, 5 para às $7 h$ eu já autorizo eles a irem entrando para organizarem a fila, ai eles organizam no pátio nós fazemos um momento de oração e damos início às aulas às 7 h10 da manhã. E, durante esse momento, tem documento pra assinar, tem um pai pra resolver problema, tem um problema com um aluno, ai eu preciso ir lá pra ver o que aconteceu. Como eles ficam com a gente do 
dia todo, ainda tem aquele que passou mal, tem que ligar pro pai, tem que ligar pra mãe." (G2)

"No meu dia-a-dia eu faço a entra da escola, faço saídas, atendo aluno, atendo pais, às vezes eu preciso... às vezes num é nem por que eu precise, às vezes é necessário mesmo. É a demanda da escola. Eu preciso sair da escola, eu faço compras de materiais para projetos, eu vou ao banco pegar saldos, às vezes eu tenho que me deslocar pra ir ao contador, essas questões." (G5)

Embora tenham se destacado as atividades administrativas, professores (57\%) e gestores (60\%) afirmam que ambas (administrativo e pedagógico) devem caminhar juntas para a consolidação dos objetivos desejados para a escola.

Diante da multiplicidade de tarefas em virtude da função, o gestor deve dominar os processos de ensino e aprendizagem que seriam

[...] o currículo, a organização pedagógico-didática (planos, metodologias, organização dos níveis escolares, horários, distribuição de alunos por classes), assistência pedagógica sistemática aos professores, avaliação, ações de formação continuada, conselhos de classe etc. (LIBÂNEO, 2004, p. 209).

E também às tarefas administrativas que fornecem apoio técnico aos docentes para o bom desempenho de seu trabalho nas várias instâncias escolares articuladas pela gestão escolar, como:

[...] Secretaria escolar, serviços auxiliares (ou serviços gerais) e serviços de multimeios A secretaria escolar realiza um conjunto de importantes atividades tais como: provimento de comunicações e informações a alunos, professores e pais, atendimento ao funcionamento pedagógico da escola (registro escolar, listas de alunos, controle de frequência, expedição de documentos, controles funcionais do pessoal docente e funcionários etc). Os serviços auxiliares referem-se à zeladoria, vigilância, responsáveis pela limpeza e conservação do prédio e equipamentos, mobiliário escolar, material didático (LIBÂNEO, 2004, p. 210).

As atividades apontadas pelos gestores e professores evidenciaram a presença de mais elementos administrativos, desenvolvidos nas rotinas diárias e sua maior incidência estaria nos atendimentos à comunidade.

Observa-se que não foram mencionados aspectos pedagógicos do processo de ensino e aprendizagem, como atividades de planejamento e avaliação, o que nos leva a pensar na atuação gestora sobrepondo a harmonização e os processos técnicos/administrativos sobre os pedagógicos. Isso leva a dois pensamentos, ou as 
funções pedagógicas estariam sendo delegadas ou se estaria dando menos ênfase a elas.

\subsubsection{As dimensões do processo de inserção na carreira}

Na primeira experiência docente após a nomeação na SEDF os professores iniciantes foram recebidos nas instituições escolares pelo gestor/diretor ou vice na maioria dos casos. Os 05 gestores escolares confirmam essa informação de que recebem os professores iniciantes e afirmam ser importante a recepção por parte do gestor. Na análise dos professores, o gestor esteve presente em 05 (45,46\%) de 11 recepções analisadas e o vice ${ }^{36}$ em $04(36,36 \%)$ e, portanto juntos, foram responsáveis por $81,82 \%$ das recepções aos professores iniciantes, conforme apontaram os professores. Vejamos a tabela:

\section{Tabela 4 - Recepção na escola}

\begin{tabular}{l|c|c}
\multicolumn{1}{c|}{ ATIVIDADES } & QTD DE RECEPÇÃO & $\%$ \\
\hline Diretor & 5 & 45,46 \\
\hline Vice-diretor & 4 & 36,36 \\
\hline Supervisor & 2 & 18,18 \\
\hline Coordenador & 2 & 18,18 \\
\hline Secretário escolar & 1 & 09,09 \\
\hline
\end{tabular}

Fonte: Elaborado pela autora da pesquisa com base na questão número 16 do questionário dos professores iniciantes (Em três casos os professores foram recebidos por mais de um profissional por isso).

Contudo, após fazerem a apresentação dos aspectos gerais da escola, $80 \%$ dos gestores afirmam encaminhar o professor recém-chegado para outros membros da equipe, geralmente o coordenador, para que este possa passar as informações de cunho pedagógico, se encarregando de uma apresentação geral, conforme relatado nas falas, vejamos:

"Aqui na escola quem recebe os professores, na verdade, sou eu, eu que recebo, que dou a ele as boas vindas e encaminho pra coordenação". (G2)

\footnotetext{
${ }^{36}$ O vice se constitui em substituto imediato do gestor, sendo aqui considerado como tal.
} 
"Então, eu gosto de conhecer e apresentar e ai eu apresento a parte geral, e ai passo para a coordenação. Para passar a parte pedagógica, é coordenador e supervisor". (G3)

Para os professores iniciantes entrevistados, em complementação a essa informação foi questionado se faria diferença ou não serem recebidos pelo gestor/diretor da escola e 03 (60\%) professores afirmaram que sim, que faz diferença.

"Faz diferença sim ser recebido pelo gestor. Você se sente, vamos colocar que de certa forma especial". (P1)

"Muita diferença até, por que quem tem que receber o professor, são as pessoas que estão na frente da escola, por que a coordenadora é importante também, mas o gestor acho que é fundamental, de dar as boas vindas". (P2)

Questionados sobre o nível de receptividade na escola, os professores iniciantes apontaram percentuais idênticos para o gestor/diretor e vice com uma regularidade entre boa e ótima.

\section{Gráfico 10 - Receptividade pelos membros da escola}

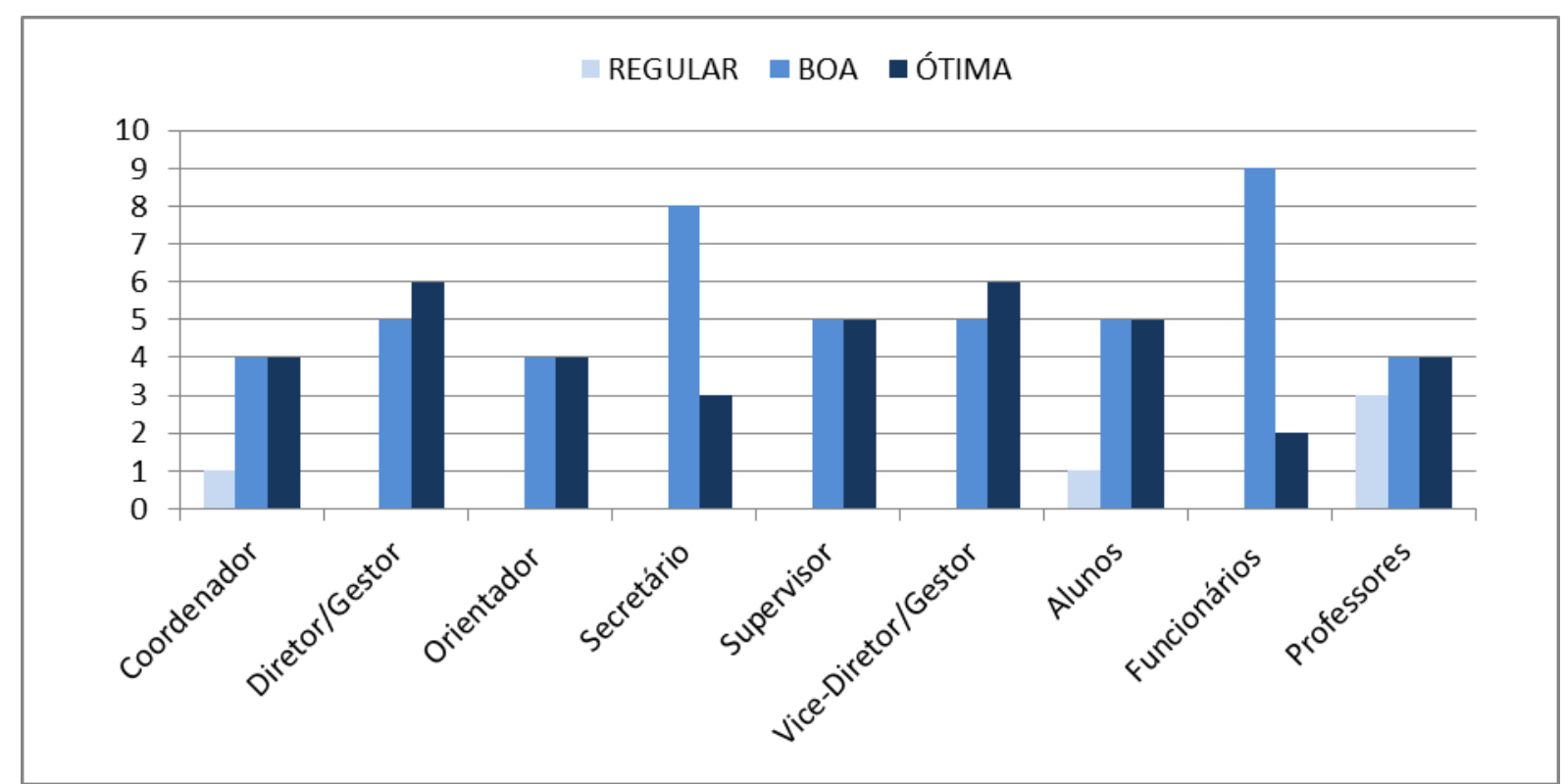

Fonte: Elaborado pela autora da pesquisa com base na questão 17 do questionário dos professores iniciantes.

E em sua maioria 08 (72,73\%) professores não entraram no primeiro dia em sala de aula, realizando outras atividades como: coordenação, reuniões, estudos de 
documentos escolares (PPP), cursos na EAPE, preencheram formulários e/ou conheceram a escola, para só depois iniciarem suas atividades docentes.

Observou-se que apenas 01 (9,09\%) professor iniciante (P4) menciona um curso para os professores ingressantes na SEDF, este curso ${ }^{37}$ é promovido pela EAPE intitulado "Integração a Carreira Magistério Público" que no período apresentou um total de 300 vagas, sendo que neste mesmo período ingressaram 1983 professores na rede (ver quadro 10 - quantitativo de professores convocados página 35), sua adesão é opcional, portanto não sendo pré-requisito para ingresso nas atividades docentes. A referida iniciativa é recente e surge em detrimento da obrigatoriedade estabelecida no artigo 11 da Lei no 5.105 de maio de 2013, que trata da qualificação profissional e obriga a SEDF a implementar, para os servidores em estágio probatório, curso de integração à carreira Magistério Público e programas de acompanhamento e avaliação. Esta ação se firma como a única prescrição legal em que o termo "Integração à Carreira Magistério Público" aparece. Nos demais documentos pesquisados a perspectiva apresenta-se no sentido da continuidade da formação para o trabalho e não como processo de inserção.

Assim, 10 professores (90,91\%) embora não tenham entrado em sala de aula de imediato, realizando outras atividades, não realizaram o referido curso e tiveram recepções e atividades distintas, tendo contato inicial diferenciado com a instituição e com as atividades docentes. Percebe-se que não há uma organização sistêmica para o atendimento de todos os professores, o que caracteriza um processo de inserção desigual aos recém-chegados.

37 Curso de Integração a Carreira Magistério em quatro versões: Educação Infantil/Anos Iniciais, Anos Finais, Anos Finais: Áreas de Linguagens, Códigos e suas Tecnologias e Ensino Médio e EJA - Educação de Jovens e Adultos - Todos tem como objetivo atender a uma exigência legal estabelecida na Lei 5.105 de 2013, que reestrutura a carreira do magistério público o DF, visando assegurar aos ingressantes na SEDF a integração a rede pública discutindo os aspectos norteadores da educação, aspectos referentes à atuação docente, a fim de contribuir para a construção da identidade profissional que favoreça a percepção do sujeito-docente como protagonista de ações e busquem consolidar uma educação pública de qualidade social, coerente com a política educacional vigente. Seu público alvo são professores iniciantes/ingressantes em 2013 e 2014, sua modalidade é presencial e a distância (p/ Ensino Médio e EJA com apenas 2 encontros presenciais), possui uma carga horária de 60 horas e com 60 vagas para Educação Infantil/Anos Iniciais, 150 vagas para Anos Finais, 60 vagas para Anos Finais (Áreas de Linguagens, Códigos e suas Tecnologias) e 30 vagas para Ensino Médio e EJA <http://www.eape.se.df.gov.br> Acesso em:10 dez. 2015. 
"Não poderíamos entrar em sala na primeira semana, porque a gente ia fazer um curso na EAPE, e só poderia entrar na sala depois desse curso". (P4)

"Por que a gente tomou posse dia 14 de julho, era numa quinta a gente tinha que dar aula numa segunda, então a gente chegava aqui, coordenava e ia pra sala de aula". (P5)

Observa-se aqui, uma contradição na instituição ao dar tratamentos diferenciados a professores com mesma condição de ingressantes/iniciantes. Por não possuírem um protocolo de instruções e procedimentos para recepcioná-los instituída pela SEDF, cada diretor adota uma forma própria de acordo com suas condições,

\begin{abstract}
"Tenho, tenho uma agenda que é a mesma que eu uso, é a minha agenda também, que a minha agenda pedagógica, é essa aqui... Ela sempre fica aqui em cima... Então é agenda pedagógica desse ano 2015, cada ano a gente muda, já tem um local pra ele colocar os abonos deles, TRE, controles deles de atestados, mensagem, calendário, coloco na agenda. $E$ aqui tem... Como nós somos educação integral, tem um resuminho do que é a educação integral, como é que tá funcionando, o sistema de avaliação da escola, está aqui, então assim, ai vai, ele tem os conteúdos, todos eles baseados no currículo em movimento". (G2)
\end{abstract}

"Num tenho um protocolo definido não, a gente conversa, senta, apresenta. Apresenta a escola, mas cada professor que chega tem uma dinâmica, depende do momento também que a gente está. A gente não tem uma coisa elaborada, formada pra dizer assim: todo o professor que chega a gente vai receber assim. É de acordo com a situação com o momento, tanto para o efetivo, quanto para o contratado, a gente não faz essa distinção aqui de profissional". (G3)

"Quando um professor chega, a gente senta com ele e a gente tem uma apresentação até pronto, posso até te mostrar, de Power Point, que a gente apresenta o PPP da escola, e como que a escola funciona, a dinâmica da escola, a gente tem também um caderno, um diário pedagógico que a gente chama e a gente explica ali como é o horário da escola, como que a escola funciona, como que os meninos lancham". (G4)

Quanto às informações repassadas aos professores iniciantes 11 professores (100\%) afirmam terem sido apresentados às estruturas físicas (ambientes, material pedagógico, materiais didáticos de apoio...), 10 professores (90,91\%) foram informados quanto as regras funcionais (horários, regimento, procedimentos administrativos, pedagógicos, disciplinares...), 09 professores (81,82\%) foram apresentados às rotinas escolares (calendário escolar, diários de classe, onde encontrar e solicitar materiais, intervalos...), 08 professores (72,73\%) foram 
apresentados às estruturas pedagógicas (planejamento, formas de avaliação, PPP, encontros pedagógicos, documentos, currículo...) e serviços de apoio ao professor e ao aluno, e 04 professores $(36,36 \%)$ receberam o perfil da turma que iria assumir.

Diante do apresentado podemos observa-se que a estrutura pedagógica não se constitui como elemento relevante quando da chegada do professor a unidade escolar, o que não aconteceu com a estrutura física e as regras funcionais. Para melhor compreensão desses dados, vejamos a tabela:

\section{Tabela 5 - Informações recebidas pelos professores na chegada à escola}

\begin{tabular}{l|c|c}
\hline \multicolumn{1}{c|}{ ATIVIDADES } & PROFESSORES & $\%$ \\
\hline $\begin{array}{l}\text { Estrutura física } \\
\text { (ambientes, materiais didático/pedagógicos...) }\end{array}$ & 11 & 100,00 \\
\hline $\begin{array}{l}\text { Regras funcionais } \\
\text { (horários, regimento escolar, procedimentos...) }\end{array}$ & 10 & 90,91 \\
\hline $\begin{array}{l}\text { Rotinas escolares } \\
\text { (calendário escolar, diários de classe, intervalos...) }\end{array}$ & 9 & 81,82 \\
\hline $\begin{array}{l}\text { Estrutura pedagógica } \\
\text { (planejamento, avaliação, currículo, PPP...) }\end{array}$ & 8 & 72,73 \\
\hline $\begin{array}{l}\text { Serviços de apoio } \\
\text { (Ao professor e ao aluno) }\end{array}$ & 8 & 36,73 \\
\hline $\begin{array}{l}\text { Perfil da turma } \\
\text { (diagnóstico e realidade da turma/turmas a } \\
\text { assumir) }\end{array}$ & 4 & 19 do questionário dos \\
\hline $\begin{array}{l}\text { Fonte: Elaborado pela autora da pesquisa com base na questão número } \\
\text { professores iniciantes. }\end{array}$ &
\end{tabular}

Os gestores escolares consideram importante apresentar aos professores iniciantes a estrutura pedagógica $(36,58 \%)$, regras funcionais $(34,15 \%)$ e rotinas escolares $(29,27 \%)$. As informações de estrutura física, serviços de apoio e perfil das turmas não foram citados pelos gestores.

Embora os gestores tenham informado que seria deles o papel de receber os professores iniciantes, percebe-se que isso se constitui somente nas boas vindas e nas informações gerais, visto que, logo delegam ao coordenador a responsabilidade de tratar com o professor das questões pedagógicas.

Para uma professora entrevistada o fato de o diretor da escola a receber fez com que ela se sentisse bem e mais próxima do diretor, Ihe concedendo maior intimidade para recorrer a ele quando necessário. Observe a fala:

"Essa recepção é muito importante [...] saber que aquela pessoa que está ali gerindo está recebendo ele [...] Eu gostei muito da recepção, por que eu 
fui recebida pelo diretor, pela vice-diretora e pelo coordenador pedagógico eu achei isso muito legal [...] Eu já trabalhei em outras escolas como contrato temporário e assim a gente não tinha oportunidade nem de chegar próxima do diretor, no sentido do diretor estar se sentido um pouco acima dos demais. Entendeu? E quando eu cheguei nessa escola eu me senti bem recebida nesse sentido de ter o diretor ali próximo pra gente poder, falar assim, estou com um problema, posso contar com o meu diretor". (P1)

Mas uma das gestoras alega não ser tão simples assim essa recepção visto que as regras na secretaria vêm mudando a cada dia, dificultando o seu trabalho e, consequentemente a atenção que dá aos professores. Vejamos:

"Olha, a gente meio que de um tempo, dos últimos concursos pra cá, a gente meio que recebe no supetão. A gente recebe, vamos lá, você vai receber tudo, até sem tempo de fazer uma formação, de fazer um contato, porque se tem um professor hoje de contrato na sala de aula e chega um efetivo, o contrato tem que ser devolvido de imediato, nem sempre há um tempo pra mostrar tudo". (G3)

Nessa fala, temos um exemplo típico de um determinante burocrático sendo imposto à unidade escolar elevando as questões administrativas acima dos interesses pedagógicos. A ação do gestor acaba por ser limitada aos seus interesses e, mesmo que queira, não the são dadas condições de proceder de maneira diferenciada, pois

[...] as condutas, as maneiras de agir e de resolver problemas e tomar decisões no âmbito da produção econômica acabam se espalhando por todo o corpo social, servindo de paradigma para as relações humanas e sociais, sejam elas econômicas ou não (PARO, 2015, p.53).

Essa visão sobre o professor como um recurso humano substituível num conjunto racional de trabalho, tratando-o como um objeto produtivo a ser substituído imediatamente por outro, desconsidera sua essência, racionaliza o trabalho a condições desumanas e demonstra a pouca preocupação com o indivíduo e sim com a instituição.

[...] Esta expressão "recursos humanos" precisa ser entendida no sentido específico de recurso do homem e não do homem como recurso. Quando se utiliza o próprio homem como recurso, não se está no âmbito da administração em geral, mas no da administração como é realizada em uma estrutura social determinada, na qual o ser humano acaba sendo tratado não como homem, mas como simples parte indiferenciada da natureza (PARO, 2012, p. 34) 
Neste sentido, o gestor escolar é, antes de tudo, um educador e, portanto, tem pleno conhecimento das implicações dos processos de transição e aprendizado na formação tanto de professores, quanto dos estudantes. Embora domine as técnicas e processos administrativos e seja conhecedor dos procedimentos pedagógicos e suas implicações, se deparam com um determinante social que o obriga a ações nem sempre por ele desejáveis e, mesmo tendo uma consciência reflexiva sobre sua situação, se vê impossibilitado de agir, mesmo estando numa posição de comando que muitos acreditam ter autonomia e autoridade. Por isso,

[...] problemas cujas soluções escapam parcial ou completamente ao seu alcance, quer porque dependem de decisões superiores, quer porque os recursos necessários não estão disponíveis, são encarados como se dependessem exclusivamente da vontade do diretor para serem resolvidos. Assim, quando as circunstâncias e o esforço pessoal permitem ao diretor resolver problemas no interior da escola, não é incomum associar-se sua imagem à de uma pessoa democrática e identificada com os interesses dominados. De modo análogo, quando os recursos disponíveis e seu poder de decisão não são suficientes para atender à justas reivindicações de melhoria do ensino e das condições de trabalho na escola, a tendência é considerá-lo autoritário articulado com os interesses dominantes (PARO, 2012, p.175)

Essa impossibilidade compromete as atividades limitando suas ações, essa situação faz com que a reprodução de um sistema econômico imposto pelo capitalismo social, interfira nas ações que muitos possuem a respeito do gestor e ampliam as dificuldades pedagógicas.

Tentando minimizar dificuldades impostas ao contexto escolar, muitos gestores recorrem a estratégias e "jeitinhos", buscando subverter uma ordem, dentro da práxis educativa que Ihes cabem, vejamos este outro relato:

\footnotetext{
"A gestora falou da regência, do horário da coordenação, qual seria o horário, e eu lembro também que ela convidou os professores temporários que estavam na nossa vaga pra poder fazer, tipo passar as informações da sala de aula pra gente, aqueles que tivessem essa disposição pra passar e que a gente também quisesse ficar um momento nas salas assistindo a aula do professor temporário, também pra conhecer mais os meninos, pra se aproximar um pouco mais deles, porque o tempo que eles tinham com a professora do contrato temporário já era um tempinho, então a gente sabe que pra criança essa questão é bem mais difícil, eles têm a professora como referência, de repente esta professora sai, entra outra, parece que é uma coisa simples mais não é, na cabeça dos pequenos é sempre algo que promove uma confusão. Então pra que a gente se aproximasse mais dos alunos e pra que eles já fossem se acostumando". (P4)
} 
No processo de transição adequado entre professores e alunos foram oportunizados às pessoas neste outro contexto uma melhor mudança e integração. Mas vejamos que isso só foi possível em virtude de outro elemento presente neste cenário, o curso ministrado ofertado à professora que estava chegando à SEDF, recém-contratada, que tinha por regra só permitir o ingresso de professores em sala de aula após a realização do mesmo.

O curso se constituiu em elemento importante para o professor e o gestor, visto que, possibilitou tempo de interação do professor iniciante aos aspectos escolares e a dinâmica do ambiente profissional. Embora seja em curto espaço de tempo permitiu um breve período de transição e adaptação.

Pensar em um processo paulatino de transição entre a teoria e a prática de modo a favorecer a adaptação processual ao mundo profissional, seja através de curso, contato prévio com a instituição, não exercendo sozinho as atividades de docência, mas compartilhando experiências e construindo uma identidade, onde "estabilizar significa acentuar o seu grau de liberdade, suas prerrogativas, o seu modo próprio de funcionamento" (HUBERMAN, 2000, p.40), pode favorecer a inserção profissional.

O curso, no mínimo permitiu um tempo de contato prévio com outros elementos (pessoas, dinâmica e estrutura) institucionais antes da entrada em sala de aula. Assim, embora seja de período curto e de pouca abrangência, precisando ser repensado, surge como elemento afirmativo, não ideal, mas importante para o processo de inserção profissional.

Conforme já mencionamos, o curso acabou se constituindo em uma contradição no sistema, visto que não foi ofertado em sua integridade a todos os professores contratados, revelando uma falta de política pública clara, organizada e adequada destinada a esses professores, que, se executado democraticamente como proposta coerente, possibilitaria a todos os gestores e professores condições semelhantes, evitando desgastes.

O exame dos resultados dessas investigações permite considerar que não há por parte da SEDF uma preocupação com o processo de inserção do professor iniciante, visto que a sua única iniciativa se consistiu em um curso de 60 horas, 
restrito a poucas vagas, desarticulado e que gera condições desiguais de acesso ao sistema educacional.

Demonstrou ainda, que as ações desenvolvidas pelos gestores são isoladas, e se norteiam pelas condições momentâneas peculiares a cada unidade escolar, portanto, perpetuam a desigualdade do sistema limitando a ação de seus gestores e tornando o processo de inserção profissional um puro diálogo informal de apresentações pouco técnicas e aligeiradas.

\subsubsection{Mediações interativas no desenvolvimento do trabalho docente}

Dado o ingresso profissional, inicia-se um novo percurso rumo ao desenvolvimento do trabalho docente dentro deste contexto escolar. As relações que se estabelecem a partir desse momento irão contribuir para a construção de uma postura profissional. As vivências iniciais são de exploração e podem ser

[...] sistemática ou aleatória, fácil ou problemática, concludente ou enganadora. No caso concreto do ensino, a exploração é limitada por parâmetros impostos pela instituição: as pessoas têm oportunidades de "explorar" poucas turmas para além das suas, poucos estabelecimentos, para além do seu, poucos papéis para além do de responsável pelas suas turmas (HUBERMAN, 2000, p.39).

Diante disso vejamos alguns relatos dos professores com relação a essas primeiras experiências na profissão:

"O meu primeiro momento era de correr, de ir embora e desistir de tudo e tchau! Isso realmente não é pra mim, não foi isso que eu esperava”. (P1)

"Sendo bem sincera! As primeiras aulas foram desesperadoras. Desesperador, de chegar em casa chorando, chorando, pensando meu Deus, meu Deus! [...] Não... É sério, foi desesperador, eu não estou brincando, eu voltava para casa chorando. Estávamos com um mês de aula eu voltava pra casa chorando todo dia e eu ainda ia pra casa de ônibus, então era um longo caminho". (P3)

"Passei por diversos momentos que eu poderia ter me desencantado, poderia ter desistido, mas não, eu gosto de trabalhar na educação [...] Me senti também um pouco impotente em relação a algumas coisas da sala de aula tipo: eu tinha um aluno que ele era muito estigmatizado na escola e ai ele me contou a história dele [...] e aquilo mexeu comigo e pra mim foi muito difícil no outro dia entrar na sala e olhar pra ele porque, vinha toda a cena na minha cabeça... (emoção), mais foi difícil os primeiros dias”. (P4) 
Dado às mudanças na profissão, em que "o papel do docente se transformou porque este se vê obrigado a assumir um maior acúmulo de responsabilidades, assim como pelo aumento das exigências às quais se encontra submetido" (VAILLANT e GARCIA, 2012, p. 15), os professores iniciantes podem ter nas relações que estabelecem com os mais experientes, 0 auxílio para o desenvolvimento do seu trabalho.

"Embora possua características comuns, a prática docente é vivenciada como um processo individual devido às diferentes situações e às características pessoais que permeiam o pensamento e as atitudes do professor diante das situações" (LIMA; CORSI, 2006, p. 64), portanto, o gestor escolar, que é, antes de tudo, um educador, de forma direta ou indireta pode atuar junto a este profissional no desenvolvimento do seu trabalho, em razão de ter por prerrogativa a articulação de um conjunto escolar do qual o professor iniciante acaba de fazer parte.

\footnotetext{
"Ela acaba ajudando a gente no dia-a-dia, seja o problema que for, dentro e fora da sala de aula. A gente pode está contando, tudo o que eu precisei ela está auxiliando sim, tanto ela quanto a vice-diretora". (P1)

"Onde eu tenho problemas de indisciplinas mais graves eu sempre recorri e eu fui atendida". (P3)
}

A coordenação, o planejamento e a avaliação das atividades desenvolvidas dentro da escola por meio de um acompanhamento sistemático, permitem ao coletivo escolar uma integração e interação, que diante das necessidades do trabalho promovem a troca de experiências e o auxílio mútuo, pois

[...] a partir da interação entre diretores, coordenadores pedagógicos, professores, funcionários e alunos, a escola vai adquirindo, na vivência do dia-a-dia, traços culturais próprios, vai formando crenças, valores, significados, modos de agir, práticas (LIBÂNEO, 2004, p.109)

Diante das dificuldades e descobertas do inicio da carreira perguntamos a professores como se estabelece sua comunicação com a equipe gestora e 10 professores (90,90\%) não tem "nenhuma" ou "pouca" dificuldade em se comunicar com seus gestores ou demais membros da equipe, alegam ainda, que sua relação com a equipe é "boa" para $09(81,82 \%)$ professores e "ótima" para $02(18,18 \%)$ professores. 
$\mathrm{Na}$ concepção dos professores iniciantes 100\% (11 professores) consideram de "importante" a "extremamente importante" as atividades de acompanhamento pela equipe gestora e se dizem "satisfeitos". Quanto ao acompanhamento 90,90\% (10 professores) afirmam que este, reflete em suas práticas docentes e acabam por atribuir responsabilidade ao gestor escolar quanto ao desenvolvimento de seu trabalho.

Quanto às atividades que desenvolvem no dia-a-dia em sua função, os 05 $(100 \%)$ gestores escolares afirmam que "frequentemente" ou "sempre":

- Certificam-se de que professores trabalham de acordo com as metas educacionais da escola;

- Utilizam os resultados de desempenho dos alunos para desenvolver as metas educacionais da escola;

- Acompanham o trabalho dos alunos.

- Informam aos professores sobre as oportunidades de atualizarem seus conhecimentos e habilidades;

- Levam em conta os resultados das provas internas e externas ao tomar decisões sobre o desenvolvimento curricular;

- Certificam-se de que existe clareza para o professor iniciante quanto às responsabilidades de coordenação da área curricular;

- Quando um professor apresenta um problema ocorrido em sala de aula, solucionam juntos os problemas.

- Estão atentos aos problemas de indisciplina nas salas de aula.

E "concordam" com as afirmativas que:

- Uma parte importante do meu trabalho é garantir que todos os envolvidos no processo ensino-aprendizagem sejam considerados coresponsáveis pelo alcance das metas da escola;

- Uma parte importante do meu trabalho é apresentar aos professores iniciantes as propostas de trabalho existentes na escola de forma convincente;

- É importante que eu verifique se todos cumprem as regras;

- É importante que eu verifique a existência de falhas e erros nos procedimentos administrativos e pedagógicos;

- Uma parte importante do meu trabalho é solucionar problemas relativos a horários e/ou planejamento das aulas; 
- Uma parte importante do meu trabalho é criar uma atmosfera ordeira na escola;

- Nesta escola trabalhamos com base nos objetivos definidos coletivamente e/ou num plano de desenvolvimento da escola;

- Eu incentivo que haja uma organização do trabalho voltada para atividades fomentadas coletivamente nesta escola.

Segundo $04(80 \%)$ dos gestores afirmam ter formas de identificar se os professores estão desempenhando bem ou mal as suas atribuições docentes e destacam as seguintes dificuldades entre os professores iniciantes: Domínio de turma, insegurança com os conteúdos, conflito teoria e prática, indisciplina dos alunos, conhecimento didático e metodologia de aprendizagem. Observe o gráfico

\section{Gráfico 11 - Dificuldades do professor iniciantes}

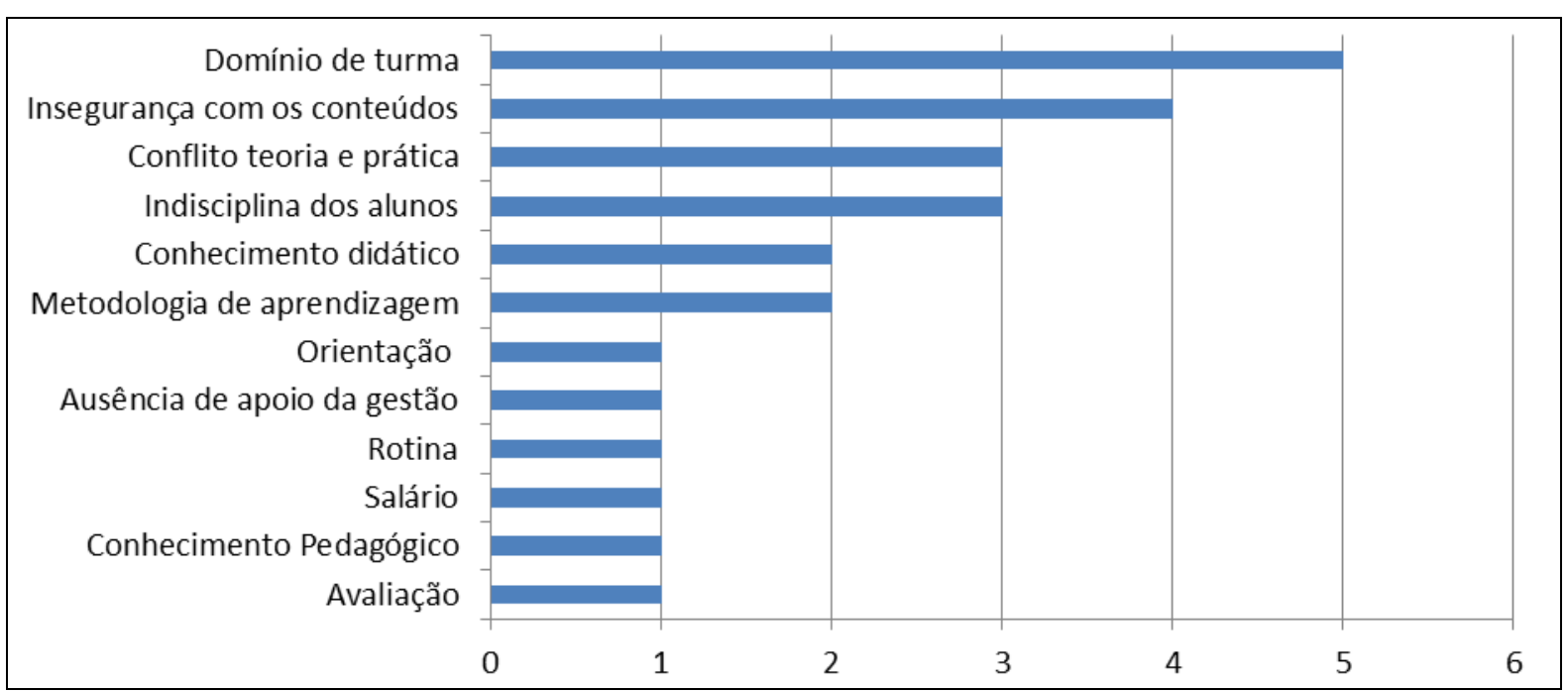

Fonte: Elaborado pela autora da pesquisa com base na questão número 36 do questionário dos gestores.

Em suas falas os professores iniciantes afirmam essas dificuldades relatando que:

"O que mais me atrapalhou mesmo foi realmente a questão da indisciplina". (P3)

"A questão mesmo é tentar passar o que a gente aprendeu para os meninos, isso é a maior dificuldade". (P5) 
Identificadas às dificuldades dos professores iniciantes os gestores escolares alegam adotar procedimentos diversos conforme suas perspectivas de gestão:

\begin{abstract}
"Mediação. Falar pra os alunos pra que primeiro conversem com o professor pra tentar resolver, assim é melhor, sem primeiro ter que ir à direção [...] pode acontecer de mesmo os alunos conversando que não resolva 0 problema, e ai a gente conversar com o professor, tenta colocar pra ele as questões da dificuldade, orientar". (G1)

"Momentos de estudos, com temas que eles precisam, precisa do planejamento, vamos fazer um momentinho pra gente falar de planejamento, como planejar, como fica boa uma aula, então tentamos fazer esses momentos, mas nós temos problemas mais graves, e nesse caso a gente chama o professor pra conversar no sentido de orientação [...]E com isso a gente vai tentado resolver e ser ponto de apoio". (G2)

"Conversa. Sempre a mediação, a gente sempre trabalha com mediação, conversa". (G3)
\end{abstract}

O trabalho em equipe e o compartilhamento das ações favorecem o processo de construção da autonomia da escola e, consequentemente, do professor iniciante, o desenvolvimento do trabalho pedagógico requer mecanismos de articulação coletiva e, portanto, conta com outros agentes presentes no contexto escolar. Assim, respeitadas as condições de insegurança e inexperiência dos professores iniciantes, o gestor escolar pode atuar de maneira direta ou indireta.

Ao coordenar e articular o conjunto escolar ele atua de maneira indireta no trabalho do professor iniciante, contudo em determinadas situações específicas se vê impelido a atuar de maneira direta, conforme relatado pelos professores e gestores.

Assim, demonstra-se que ao gestor escolar caberia desenvolver um trabalho no sentido de:

- Compartilhar as decisões;

- Assegurar a participação de todos;

- Definir com clareza as competências dos membros da equipe

- Desenvolver ações coletivas articulando o trabalho em equipe;

- Garantir a disponibilidade de tempo para reuniões e aperfeiçoamento; 
- Garantir o acesso a informações e a transparência dos processos administrativos e pedagógicos;

- Incentivar e reconhecer a colaboração de todos frente aos aspectos favoráveis e desfavoráveis do processo educativo da instituição como um todo, valorizando a vivência democrática na instituição.

- Definir coletivamente e cuidar para o bom andamento da agenda escolar.

Ao agir deste modo o gestor escolar contribui para que os processos de gestão se articulem ao desenvolvimento do trabalho docente estabelecendo uma intimidade profissional favorável ao docente.

É importante lembrar que nem tudo está sob o controle do gestor da unidade escolar, visto os poderes públicos e suas ingerências ideológicas constituídas nas esferas administrativas do sistema educacional, limitam os interesses e sua atuação profissional.

Consideradas, ainda, as múltiplas determinações sociais que, refletidas dentro das instituições promovem condições desfavoráveis e desiguais, o gestor nem sempre atua num contexto adequado ao bom andamento das atividades escolares. Portanto, o processo de gestão adotado e a perspectiva de atuação incorporada, conduzem sua relação com a comunidade escolar e refletem na realização de suas atividades, incidindo no apoio dado ao desenvolvimento do trabalho docente. 


\section{CONSIDERAÇÕES REFLEXIVAS}

Em razão dos estudos e das reflexões apresentadas, reitera-se, portanto, que o processo de inserção dos professores iniciantes se constitui em um momento peculiar na carreira, não só pela condição de exploração e socialização profissional, mas também por repercutir na relação que estes estabelecem com a profissão dali por diante. Os professores iniciantes realizam suas apreciações a respeito das possibilidades que se apresentam a eles nos primeiros contatos com a carreira e a depender das reflexões e experiências vivenciadas avaliam a possibilidade de desistir ou permanecer na profissão.

As maiores dificuldades destes professores reveladas por esta pesquisa reafirmaram o que já vem sendo declarado por estudos neste campo, ou seja, estabelecer o domínio de turma, definir corretamente os conteúdos, realizar a adequada relação entre teoria e prática, controlar a disciplina dos alunos e desenvolver adequadamente o conhecimento didático metodológico dos processos de ensino aprendizagem, se constituem em seus principais desafios.

Aliado a estas dificuldades, verifica-se que estes professores são encaminhados por força de portaria às unidades escolares situadas em regiões periféricas, com período mínimo de permanência previamente definido. Estas escolas se constituem em locais de trabalho pouco atrativo devido a sua localização geográfica e com público geralmente desprovido nos aspectos econômicos, culturais, sociais, entre outros. Assim, este professor inicia sua atividade profissional em unidades escolares com circunstâncias de trabalho adversas e fragilizadas.

Essas unidades, de acordo com os gestores escolares, geralmente contam com um alto índice de rotatividade profissional, visto que os professores a elas encaminhados permanecem somente o período mínimo exigido e depois realizam suas movimentações visando melhores condições de trabalho, fato comprovado pelo número de professores movimentados expressos no quadro 13 - Destinação e permanência de professores para o período (p. 37) - em que 85 de 156 professores já haviam sido movimentados das escolas para as quais tinham sido designados inicialmente. Esta elevada taxa de rotatividade docente dificulta entre outras coisas, a consolidação de processos. 
Com características pouco atrativas e excessiva rotatividade profissional a dinâmica de trabalho exige dos gestores uma maior capacidade de articulação e mediação para garantir a realização e continuidade do trabalho pedagógico. Este contexto escolar, que pelo contrário deveria conter profissionais mais experientes e possuir estímulos profissionais que compensassem as dificuldades geradas pelas múltiplas determinações sociais sob as quais a escola está submetida, revela uma contradição, visto que, onde se exige mais experiência, preparo e recursos, destinam-se os mais inexperientes, ou seja, quanto maior a carência, maior é a necessidade de professores experientes e disponibilidade de recursos para compensar o desequilíbrio e permitir qualidade e avanços nos processos educativos que permitam equacionar as diferenças causadas pela lógica cruel e desumana da sociedade capitalista.

Diante desta realidade, a iniciação na prática docente no DF ocorre em condições desfavoráveis, que limitam a ação do professor e ampliam o leque de necessidades e complicações que podem vir a repercutir no seu trabalho e seus respectivos resultados.

Estes aspectos até então mencionados, extrapolam a competência do gestor e também recaem sobre o seu trabalho limitando-o, ao mesmo tempo em que exigem uma perspectiva complexa de sua função. Portanto, cabe ao gestor uma maior habilidade e conhecimento profissional, administrativo, pedagógico, representativo e harmonizador, que the permita auxiliar o professor iniciante junto a estes aspectos desfavoráveis, objetivando o desenvolvimento profissional docente e consequentemente $o$ adequado funcionamento da unidade escolar.

Esta pesquisa identificou uma única ação de recepção e/ou inserção de professores na esfera central, que consiste em um curso de formação à distância (encontro inicial/final - presenciais) de 60 horas, realizado por meio da plataforma digital da EAPE, com número de vagas inferior à demanda.

A referida iniciativa é recente e surge em consequência da obrigatoriedade estabelecida no artigo 11 da Lei no 5.105 de maio de 2013, que trata da qualificação profissional e obriga a SEDF a implementar, para os servidores em estágio probatório, curso de integração à carreira magistério público e programas de acompanhamento e avaliação. Esta ação se firma como a única prescrição legal em 
que o termo "Integração" aparece. Nos demais documentos pesquisados, o entendimento apresenta-se no sentido da continuidade da formação para o trabalho e não como processo de inserção. Contudo, ainda é inócua, pois a adesão ao curso é opcional, não sendo um pré-requisito para ingresso nas atividades docentes, o número de vagas não atende, a carga horária é pequena, o curso é a distância e segundo alguns professores entrevistados, pouco divulgado, pois desconhecem o curso, muito embora tenha interesse em realizá-lo.

Constatou-se também que os gestores escolares não possuem suporte ou instrução por parte da Secretaria de Educação do Distrito Federal, quanto ao processo de inserção docente no trabalho escolar e a ausência de normativa que sistematize e coordene procedimentos de forma institucional, faz com que esta fase na carreira seja conduzida de maneira diversificada, pontual, aleatória e particular, pautada nos interesses, conhecimentos e possibilidade do gestor e sua unidade, ocasionando um tratamento desigual e pouco técnico quando da chegada do professor iniciante.

Portanto, a recepção dos professores iniciantes por parte do gestor escolar, acaba sendo um breve contato em que este apresenta aquilo que julga necessário repassar, frequentemente elementos administrativos e de caráter funcional. Em seguida transfere a outros membros de sua equipe a responsabilidade pelas demais informações, atribuindo geralmente aos coordenadores e supervisores os aspectos pedagógicos, o processo de socialização deste professor junto aos seus pares e a supervisão e o acompanhamento de seu trabalho. Diante disso, dependendo de como o gestor compreenda a perspectiva de sua função, que pode levar a dicotomia entre administrativo e pedagógico, este pode se afastar do professor iniciante não acompanhando ou auxiliando-o, destinando o seu tempo para outras atividades que julgue serem mais relevantes, não aferindo o devido valor aos aspectos de desenvolvimento profissional docente dos professores iniciantes.

Devido às diversas atividades e situações das quais o gestor tem por atribuição articular, sabe-se que sua demanda é intensa, por isso o trabalho de gestão escolar se alicerça em uma equipe, em que as atribuições e o todo, são compartilhados, fazendo com que a divisão de tarefas seja um componente evidente para a eficiência e eficácia do trabalho em equipe, desobrigando-o da total 
responsabilidade sobre o processo de inserção de um professor no âmbito escolar e no trabalho docente.

Entretanto é necessário frisar que o entendimento da perspectiva complexa da função de gestor atribui amplitude à suas ações, fortalecendo a visão de que é fundamental atuar junto a todas as esferas de alcance das atividades escolares de maneira equilibrada, equacionando as necessidades e os interesses pertinentes, não devendo o gestor escolar priorizar determinadas atividades em função de outras, nem tampouco delegar totalmente as demandas de trabalho, mas descentralizá-las com supervisão e equilíbrio, embora tenham alegado um elevado número de atividades a serem desempenhadas, conduzindo os processos educacionais com conhecimento e liderança,

Embora o professor iniciante considere o apoio dado pela equipe gestora ao seu trabalho, afirma se sentir valorizado ao ser recebido pelo gestor escolar, só a recepção não é suficiente, visto a relevância dos processos de acompanhamento mencionados por estes professores, que afirmam interferir no aprimoramento e ordenamento de suas atividades e práticas educativas.

Sentir-se experiente e seguro, para contestar as práticas nem sempre questionadas e impor o próprio ritmo, requer saberes pedagógicos específicos, construídos por meio de um trabalho coletivo, responsável, sistemático e consistente, que permitirá ao professor iniciante o adequado conhecimento e contato com os processos pedagógicos da unidade escolar. $O$ desenvolvimento de processos democráticos se constitui em elemento favorável a participação através do compartilhamento de ideias e experiências entre professores. Essa dinâmica de trabalho coordenada pelo gestor escolar auxilia no processo de inserção e no desenvolvimento do trabalho docente, mas não se constitui em única possibilidade de atuação.

Assim, embora não seja de responsabilidade única e exclusiva das escolas, o processo de inserção profissional necessita contar, entre outras coisas, com o apoio dos colegas experientes e com uma dinâmica democrática de participação, pois compreender e se habituar ao ambiente escolar de modo a se sentir seguro na profissão, implica em um aprendizado construído em meio às relações e interações que se fazem dentro do ambiente escolar, mas que devem ser cautelosamente 
edificados. Caso contrário, os saberes específicos da profissão podem ser assimilados de maneira assimétrica e aleatória no dia-a-dia, por meio de compartilhamentos casuais com os colegas.

Por ser a SEDF um sistema educacional amplo e diferenciado, é necessário desenvolver técnicas e procedimentos coordenados por instâncias centrais e superiores às unidades escolares, por meio de políticas públicas articuladas, coerentes e sustentáveis, fornecendo aos gestores estrutura e condições para que possam adequadamente e coordenadamente, apoiar aqueles que ingressam na profissão, de forma a minimizar as desigualdades sistêmicas e de inserção, já tão intensificadas por outras múltiplas determinações sociais reproduzidas no ambiente educacional.

Por fim, identifica-se como estando vulnerável e carecendo de atenção, o processo de inserção docente na Carreira do Magistério Público do DF, devido à ausência de uma política eficaz por parte da SEDF, uma vez que esta socialização profissional pode ser primordial na permanência e no aperfeiçoamento das atividades docentes e seus respectivos resultados. Logo, sugere-se o aprofundamento deste estudo, visando investigar possibilidades de ações que auxiliem a SEDF e seus respectivos gestores, na consolidação de procedimentos adequados ao processo de inserção de professores iniciantes no trabalho docente, padronizando procedimentos, atividades e fases de adaptação, conduzindo paulatinamente a inserção profissional, evitando tratamentos desiguais $\mathrm{e}$ minimizando as dificuldades inerentes ao início da carreira. 


\section{REFERÊNCIAS}

ALMEIDA, L. R. D.; PRANDINI, R. C. A. R.; SZYMANSKI, H. Entrevista na Pesquisa em Educação - a prática reflexiva. 4. ed. Brasília: Liber Livro, 2011.

ANDRÉ, M. Políticas e Programas de Apoio aos Professores Iniciantes no Brasil. CONGREPRINC. Santiago: [s.n.]. 2012.

ANDREOTTI, A. L.; LOMBARDI, J. C.; MINTO, L. W. História da Administração Escolar no Brasil: Do diretor ao gestor. 2. ed. Campinas: Editora Alínea, 2012.

ANTUNES, R. Os sentidos do trabalho: ensaio sobre a afirmação e negação do trabalho. São Paulo: Boitempo, 1999.

APPLE, M. W. Trabalho docente e textos: Economia política das relações de classe e de gênero em educação. Porto Alegre: Artes Médicas, 1995.

BARDIN, L. Análise de Conteúdo. São Paulo: Edições 70, 2011.

BRASIL. Ministério da Educação. Relatório Nacional - TALIS (Pesquisa Internacional sobre Ensino e Aprendizagem). Brasília, 2014.

Lei 9.394, de 20 de dezembro de 1996. Estabelece as diretrizes e bases da educação nacional. Brasília, 1996.

COSTA, J. A.; CASTANHEIRA, P. A liderança na gestão das escolas: contributos de análise organizacional. Revista brasileira de política e administração da educação, Recife, v. 31, p. 13-44, janeiro/abril 2015.

CRUZ, S. P. D. S.; NETO, J. B. A polivalência no contexto da docência nos anos iniciais da escolarização básica: Refletindo sobre experiências de pesquisa. Revista Brasileira de Educação, v. 17, maio-ago 2012.

CUNHA, C. et al. O método dialético na pesquisa em educação. 1. ed. Campinas - SP: Autores Associados/Brasília, DF: Faculdade de Educação, UnB, 2014.

CURADO SILVA, K. A. P. C. D. Professores com formação Stricto sensu e o desenvolvimento da pesquisa na educação básica da rede pública de Goiânia: realidades, entraves e possibilidades. Goiânia: Faculdade de Educação UFG. 2008. p. 292.

CURADO SILVA, K. A. P. C. D.; NUNES, D. F. Desenvolvimento profissional docente: conceituando o início da carreira. Brasília, 2015. 1-15. 
CURY, C. R. J. Educação e contradição: Elementos metodológicos para uma teoria crítica do fenômeno educativo. 7. ed. São Paulo: Cortez, 2000.

ENGUITA, M. F. A. A ambiguidade da docência: entre profissionalismo e a proletarização. Teoria \& Educação, Porto Alegre, v. 4, p. 41-61, 1991.

FILHO, L. M. D. F.; VIDAL, D. G. Os tempos e os espaços escolares no processo de institucionalização da escola primaria no Brasil. Revista Brasileira de Educação, v. 14, p. 19-34, Maio/Agosto 2000.

GADOTTI, M. Concepção Dialética da Educação - Um estudo introdutório. 16. ed. São Paulo: Cortez, 2012.

GAMBOA, S. S. Pesquisa em educação: métodos e epistemologias. Chapecó: Argos, 2007.

GARCIA, C. M. O professor iniciante, a prática pedagógica e o sentindo da experiência. Formação Docente, Belo Horizonte, v. 02, n. 03, p. 11-49, ago/dez 2010.

GDF. Lei 957, de 22 de novembro de 1995. Dispõe sobre a gestão democrática da escola pública. Diário Oficial do Distrito Federal. Brasília, DF.

. Lei 4.036, de 25 de outubro de 2007. Dispõe sobre a gestão compartilhada nas instituições educacionais da rede pública do DF. Diário Oficial do Distrito Federal. Brasília, DF.

Lei 4.751, de 08 de fevereiro de 2012. Dispõe sobre o Sistema de Ensino e a Gestão Democrática de Ensino Público do Distrito Federal. Diário Oficial do Distrito Federal. Brasília, DF.

Lei 5.105, de 03 de maio de 2013. Reestrutura a carreira magistério Público do Distrito Federal e dá outras providências. Diário Oficial do Distrito Federal, DF.

Portaria no 219 de 14 de outubro de 2014. Dispõe sobre normas para lotação, exercício, remanejamento externo e interno de servidores integrantes da Carreira Magistério Público do Distrito Federal. Brasília, DF.

Secretaria de Educação. Diretrizes Pedagógicas. Brasília: DF, 2009.

Secretaria de Educação. Regimento escolar das instituições educacionais da rede pública de ensino do Distrito Federal. Brasília: DF. 2009.

GIL, A. C. Métodos e técnicas de pesquisa social. 6. ed. São Paulo: Atlas, 2008. 
HUBERMAN, M. O ciclo de vida profissional de professores. In: Nóvoa, A. (Org.). Vida de professores. Porto: Porto, 2000.

KOPNIN, P. V. A dialética como lógica e teoria. Rio de Janeiro: Civilização Brasileira, 1978.

KUENZER, Z. A.; CALDAS, A. Trabalho docente: Comprometimento e resistência. In: OLIVEIRA, M. A. M.; FIDALGO, N. L. R. A intensificação do trabalho docente: tecnologias e produtividade. Campinas: Papirus, 2009. p. 19-48.

LIBÂNEO, J. C. Organização e gestão da escola: teoria e prática. Goiânia: Alternativa, 2001.

LIMA, E. F. D.; CORSI, A. M. [et al. ]. Sobrevivência no início da docência. Brasília: Líber, 2006.

LUCK, H. Gestão educacional: Uma questão paradigmática. 2. ed. Petrópolis: Vozes, 2011. Série cadernos de gestão.

MARX, K.; ENGELS ,. A ideologia alemã: Crítica da mais recente filosofia alemã em seus representantes Feuerbach, B. Bauer e Stirner, e do socialismo alemão em seus diferentes profetas. Tradução de Rubens Enderle, Nélio Schneider, Luciano Martorano. São Paulo: Boitempo, 2007.

MOROZ, M.; GIANFALDONI, M. H. T. A. O processo de pesquisa: iniciação. 2. ed. Brasília: Liber, 2006. OCDE. Panorama da Educação: Indicadores / Edição 2006. Disponível em <http:// http://www.oecd.org/education/skills-beyondschool/37393599.pdf>. Acesso em: 18 nov. 2015.

OLIVEIRA, D. A.; VIEIRA, L. F. Trabalho na educação básica: a condição docente em sete estados brasileiros. Belo Horizonte: Fino Traço, 2012.

PARO, V. H. Crítica da Estrutura da Escola. São Paulo: Cortez, 2011.

PARO, V. H. Adminsitração Escolar: Introdução Crítica. São Paulo: Cortez, 2012.

PARO, V. H. Diretor escolar: Educador ou gerente? São Paulo: Cortez, 2015.

PEREIRA, E. W. [. A. ]. Nas asas de Brasília. Brasília: Universidade de Brasília:, 2011. 
PIERI, G. D. S. D.; TANCREDI, R. M. S. P. O papel da Equipe Pedagógica e da Direção na atuação de professores iniciantes das séries iniciais do ensino fundamental. Cadernos da Pedagogia, p. 91 a 115, Janeiro a Julho I.

ROLDÃO, M. D. C. Natureza e construção do conhecimento profissional. Revista Brasileira de Educação, v. 12, n. 34, p. 94-103, janeiro/abril 2007.

ROMANOWSKI, J. P.; SOCZEK, D. Políticas públicas de inserção de professores iniciantes: Elementos para reflexão. CONGREPRINC. Curitiba: [s.n.]. 2014.

SANDER, B. Administração da Educação no Brasil - Genealogia do conhecimento. Brasília: Liber Livro, 2007.

SAVIANI, D. Escola e Democracia. 42. ed. Campinas - SP: Autores Associados, 2012.

SEVERINO, A. J. O projeto político pedagógico: a saída para a escola, São Paulo, 07 Fevereiro 2008. 01-08.

VAILLANT, D.; GARCIA, C. M. Ensinando a ensinar: as quatro etapas de uma aprendizagem. 1. ed. Curitiba: UTFPR, 2012.

VIEIRA, S. Como elaborar questionários. São Paulo: Atlas, 2009. 


\section{APÊNDICES}

1. Questionário dos Gestores

2. Questionário dos Professores

3. Roteiro de entrevista dos Gestores

4. Roteiro de entrevista dos Professores 


\title{
APÊNDICE 1 - QUESTIONÁRIO DOS GESTORES
}

\author{
T \\ UNIVERSIDADE DE BRASÍLIA \\ FACULDADE DE EDUCAÇÃO \\ PROGRAMA DE PÓS-GRADUAÇÃO EM EDUCAÇÃO
}

Caro(a) Gestor(a),

O presente questionário tem por objetivo coletar dados a cerca da atuação da gestão escolar das escolas públicas do DF no processo de inserção do professor iniciante no trabalho docente. Pedimos a gentileza de colaborar com nossa pesquisa respondendo a esse questionário, marcando o campo correspondente à alternativa de sua escolha. As informações fornecidas por vocês terão o anonimato garantido e serão de fundamental importância para o bom andamento deste estudo.

Agradeço sua disponibilidade e me coloco à disposição para maiores esclarecimentos.

Grata!!!

\section{IDENTIFICAÇÃO DO GESTOR}

1. IDADE: ( ) menos de 24 anos ( ) 25 a 35 ( ) 36 a 45 ( ) 46 a 50 ( ) mais de 50

2. SEXO: ( ) Feminino ( ) Masculino

3. ADMISSÃO:

\section{DADOS INSTITUCIONAIS}

4. COORDENAÇÃO REGIONAL DE ENSINO:

5. TIPO DE ATENDIMENTO:

( ) Educação Infantil

( ) Ensino Fundamental - anos iniciais

( ) Ensino Fundamental - anos finais

( ) Ensino Médio

6. LOCALIZAÇÃO: （）Zona Urbana （）Zona Rural

7. TURNOS DE ATENDIMENTO DA ESCOLA:

( ) Matutino ( ) Intermediário ( ) Vespertino ( ) Noturno ( )Turno Único

8. QUANTIDADE DE TURMAS NA ESCOLA:

9. QUANTIDADE DE PROFESSORES REGENTES: 


\section{FORMAÇÃO DO GESTOR(A)}

10. CARGO: ( ) Diretor(a) ( ) Vice-Diretor(a)

11. NíVEL DE GRADUAÇÃo (em caso de mais de uma colocar a mais recente):

( ) Ensino Médio (Normal Magistério).

( ) Ensino Superior (Pedagogia).

( ) Ensino Superior (Escola Normal Superior).

( ) Ensino Superior (outras licenciaturas:

( ) Ensino Superior (outro:

12. HÁ QUANTOS ANOS VOCÊ OBTEVE O NÍVEL DE ESCOLARIDADE ASSINALADO ANTERIORMENTE?
( ) Há 2 anos ou menos
( ) De 3 a 7 anos.
( ) De 8 a 14 anos.
( ) De 15 a 20 anos.
( ) Há mais de 20 anos.

13. EM QUE TIPO DE INSTITUIÇÃO VOCÊ FEZ O CURSO SUPERIOR? (Em caso de mais de um, assinale aquela em que obteve o seu título profissional)
( ) Pública Federal.
( ) Pública Estadual.
( ) Pública Municipal.
( ) Privada.
( ) Não se aplica.

14. TIPO DE REALIZAÇÃO DO CURSO:
( ) Presencial.
( ) Semipresencial.
( ) À distância.
( ) Em serviço.
( ) Não se aplica.

15. INDIQUE A MODALIDADE DO CURSO DE PÓS-GRADUAÇÃO DE MAIS ALTA TITULAÇÃO QUE VOCÊ POSSUI.
( ) Atualização (mínimo de 180hs).
( ) Especialização (mínimo de 360hs).
( ) Mestrado Acadêmico.
( ) Mestrado Profissional.
( ) Doutorado.
( ) Não fiz ou ainda não completei curso de pós-graduação. (Área: 
16. POSSUI CURSO ESPECÍFICO EM GESTÃO ESCOLAR?

( ) Não

( ) $\operatorname{Sim}($ Qual:

17. HÁ QUANTOS ANOS VOCÊ TRABALHA EM EDUCAÇÃO?

\begin{tabular}{|l|l|l|l|l|l|}
\hline Primeiro ano & $2-3$ & $4-5$ & $6-7$ & $8-9$ & + de 10 anos \\
\hline & & & & & \\
\hline
\end{tabular}

18. HÁ QUANTOS ANOS VOCÊ TRABALHA NA SEDF?

\begin{tabular}{|l|l|l|l|l|l|}
\hline Primeiro ano & $2-3$ & $4-5$ & $6-7$ & $8-9$ & + de 10 anos \\
\hline & & & & & \\
\hline
\end{tabular}

19. QUANTOS ANOS VOCÊ TRABALHOU COMO PROFESSOR REGENTE ANTES DE EXERCER A FUNÇÃO DE DIRETOR OU VICE-DIRETOR?

\begin{tabular}{|l|l|l|l|l|l|}
\hline Primeiro ano & $2-3$ & $4-5$ & $6-7$ & $8-9$ & + de 10 anos \\
\hline & & & & & \\
\hline
\end{tabular}

20. QUANTOS ANOS DE EXPERIÊNCIA VOCÊ POSSUI TRABALHANDO COMO DIRETOR OU VICE-DIRETOR?

\begin{tabular}{|l|l|l|l|l|l|}
\hline Primeiro ano & $2-3$ & $4-5$ & $6-7$ & $8-9$ & + de 10 anos \\
\hline & & & & & \\
\hline
\end{tabular}

21. QUANTOS ANOS DE EXPERIÊNCIA VOCÊ POSSUI TRABALHANDO COMO DIRETOR OU VICE-DIRETOR NESTA ESCOLA?

\begin{tabular}{|l|l|l|l|l|l|}
\hline Primeiro ano & $2-3$ & $4-5$ & $6-7$ & $8-9$ & + de 10 anos \\
\hline & & & & & \\
\hline
\end{tabular}

22. VOCÊ ASSUMIU A DIREÇÃO DESSA ESCOLA POR:
( ) Seleção
( ) Eleição apenas.
( ) Seleção e eleição.
( ) Indicação de técnicos.
( ) Indicação de políticos.
( ) Outras indicações.
( ) Outras formas. 
23. QUAL A SUA CARGA HORÁRIA DE TRABALHO NESTA ESCOLA:
( ) Até 20 horas semanais.
( ) Até 40 horas semanais.
( ) Até 30 horas semanais.
( ) Mais de 40 horas semanais.

\section{RECEPÇÃO AOS PROFESSORES INICIANTES}

24. QUEM GERALMENTE RECEBE OS PROFESSORES INICIANTES NA SUA ESCOLA?
( ) Coordenador Pedagógico
( ) Supervisor Pedagógico
( ) Supervisor Administrativo
( ) Diretor
( ) Vice-Diretor
( ) Professor
( ) Outros. Especifique

25. VOCÊ GESTOR, ENFRENTA ALGUMA DIFICULDADE PARA RECEBER E ORIENTAR OS PROFESSORES INICIANTES?
( ) Sim
( ) Não

CASO A RESPOSTA SEJA “SIM”. DESCREVA-AS:

26. DESCREVA OS PROCEDIMENTOS ADOTADOS POR VOCÊ QUANDO DA CHEGADA DE UM PROFESSOR INICIANTE NA CARREIRA.

27. OUTROS PROCEDIMENTOS SÃO REALIZADOS NA ESCOLA PARA A RECEPÇÃO DOS PROFESSORES INICIANTES? QUAIS? QUEM GERALMENTE OS REALIZA? 
28. QUE ORIENTAÇÕES SÃO REPASSADAS AOS PROFESSORES INICIANTES NA PRIMEIRA SEMANA DE TRABALHO NA ESCOLA? DESCREVA-AS.

29. COMO É REALIZADA A APRESENTAÇÃO DOS PROFESSORES INICIANTES AOS DEMAIS PROFESSORES DA ESCOLA? FAÇA UMM BREVE RELATO DESCRITIVO.

30. NO PRIMEIRO DIA EM QUE O PROFESSOR INICIANTE CHEGA À ESCOLA, ESTE É ENCAMINHADO DIRETAMENTE PARA A SALA DE AULA?

( ) $\operatorname{Sim}($ ) Não

CASO A RESPOSTA SEJA "NÃO”, QUE ATIVIDADE É REALIZADA COM ESTE PROFESSOR? DESCREVA-AS:

CASO A RESPOSTA SEJA "SIM", LHE É REPASSADA ALGUMA INSTRUÇÃO OU ATIVIDADE PLANEJADA PARA EXECUÇÃO?

( ) Sim. Qual?
( ) Não

31. QUE INFORMAÇÕES VOCÊ JULGA SEREM NECESSÁRIAS REPASSAR AO PROFESSOR INICIANTE, QUANDO DE SUA CHEGADA À ESCOLA? DESCREVA-AS:

Informações Administrativas:

Informações Pedagógicas: 


\title{
32. QUE DOCUMENTOS SÃO APRESENTADOS AO PROFESSOR INICIANTE QUANDO DA SUA CHEGADA À ESCOLA?
}

\author{
( ) Projeto Político Pedagógico \\ ( ) Diretrizes Pedagógicas \\ ( ) Diretrizes Avaliativas \\ ( ) Regimento Escola da Rede Pública de Ensino do Distrito Federal \\ ( ) Outros. Especifique
}

33. VOCÊ ENCONTRARÁ A SEGUIR AFIRMAÇÕES SOBRE A SUA GESTÃO NESTA ESCOLA. POR FAVOR, INDIQUE COM QUE FREQUÊNCIA ESTAS ATIVIDADES E ESTES COMPORTAMENTOS OCORRERAM NESTA ESCOLA DURANTE O ATUAL ANO LETIVO.

\begin{tabular}{|c|c|c|c|c|c|}
\hline & Por favor, marque apenas uma alternativa em cada linha. & $\begin{array}{l}\mathrm{Nu} \\
\mathrm{nc} \\
\mathrm{a}\end{array}$ & $\begin{array}{l}\text { Ra } \\
\text { ra } \\
\text { me } \\
\text { nte }\end{array}$ & $\begin{array}{l}\text { Fre } \\
\text { qu } \\
\text { ent } \\
\text { em } \\
\text { ent } \\
\text { e }\end{array}$ & $\begin{array}{l}\text { Se } \\
\mathrm{mp} \\
\text { re }\end{array}$ \\
\hline a. & $\begin{array}{l}\text { Certifico-me de que as atividades de desenvolvimento profissional } \\
\text { dos professores estejam de acordo com as metas educacionais da } \\
\text { escola. }\end{array}$ & & & & \\
\hline b. & $\begin{array}{l}\text { Certifico-me de que os professores trabalhem de acordo com as } \\
\text { metas educacionais da escola. }\end{array}$ & & & & \\
\hline c. & Observo o ensino em sala de aula. & & & & \\
\hline d. & $\begin{array}{l}\text { Utilizo os resultados de desempenho dos alunos para desenvolver } \\
\text { as metas educacionais da escola. }\end{array}$ & & & & \\
\hline e. & $\begin{array}{l}\text { Dou sugestões aos professores de como eles podem melhorar o } \\
\text { seu ensino. }\end{array}$ & & & & \\
\hline f. & Acompanho o trabalho dos alunos. & & & & \\
\hline g. & $\begin{array}{l}\text { Quando um professor tem problemas em sua(s) sala(s) de aula, } \\
\text { tomo a iniciativa de discutir com ele os problemas. }\end{array}$ & & & & \\
\hline h. & $\begin{array}{l}\text { Informo aos professores sobre as oportunidades de atualizarem } \\
\text { seus conhecimentos e habilidades. }\end{array}$ & & & & \\
\hline i. & $\begin{array}{l}\text { Verifico se as atividades em sala de aula estão adequadas as metas } \\
\text { educacionais da escola. }\end{array}$ & & & & \\
\hline j. & $\begin{array}{l}\text { Levo em conta os resultados das provas internas e externas ao } \\
\text { tomar decisões sobre o desenvolvimento curricular. }\end{array}$ & & & & \\
\hline
\end{tabular}




\begin{tabular}{|l|l|l|l|l|l|}
\hline k. & $\begin{array}{l}\text { Certifico-me de que existe clareza para o professor iniciante quanto } \\
\text { às responsabilidades de coordenação da área curricular. }\end{array}$ & & & \\
\hline I. & $\begin{array}{l}\text { Quando um professor apresenta um problema ocorrido em sala de } \\
\text { aula, solucionamos o problema conjuntamente. }\end{array}$ & & & \\
\hline m. & Estou atento(a) aos problemas de indisciplina nas salas de aula & & & \\
\hline n. & $\begin{array}{l}\text { Assumo as aulas dos professores que estiverem inesperadamente } \\
\text { ausentes. }\end{array}$ & & & \\
\hline
\end{tabular}

34. INDIQUE SEU GRAU DE DISCORDÂNCIA OU CONCORDÂNCIA COM CADA UMA DAS AFIRMAÇÕES A SEGUIR NO QUE DIZ RESPEITO A ESTA ESCOLA, SEU TRABALHO E SEUS PROFESSORES:

\begin{tabular}{|c|c|c|c|c|c|}
\hline & Por favor, marque apenas uma alternativa em cada linha. & $\begin{array}{l}\mathrm{Di} \\
\mathrm{sc} \\
\text { or } \\
\text { do } \\
\text { To } \\
\text { tal } \\
\text { me } \\
\text { nte }\end{array}$ & $\begin{array}{l}\text { Di } \\
\text { sc } \\
\text { or } \\
\text { do }\end{array}$ & $\begin{array}{l}\text { Co } \\
\text { nc } \\
\text { or } \\
\text { do }\end{array}$ & $\begin{array}{l}\text { Co } \\
\text { nc } \\
\text { or } \\
\text { do } \\
\text { To } \\
\text { tal } \\
\text { me } \\
\text { nte }\end{array}$ \\
\hline a. & $\begin{array}{l}\text { Uma parte importante do meu trabalho é assegurar que } \\
\text { professores iniciantes recebam explicações sobre as } \\
\text { abordagens de ensino aprovadas pelo Ministério da Educação e } \\
\text { que os professores mais experientes estejam utilizando essas } \\
\text { abordagens. }\end{array}$ & & & & \\
\hline b. & $\begin{array}{l}\text { Usar as notas que os alunos obtiveram nas provas externas e } \\
\text { internas para avaliar o desempenho de um professor } \\
\text { desvaloriza o julgamento profissional do professor. }\end{array}$ & & & & \\
\hline c. & $\begin{array}{l}\text { Dar aos professores liberdade para escolher suas metodologias } \\
\text { de ensino pode levar a um ensino fraco. }\end{array}$ & & & & \\
\hline d. & $\begin{array}{l}\text { Uma parte principal do meu trabalho é garantir que a } \\
\text { competência para ensinar da equipe escolar esteja em } \\
\text { desenvolvimento contínuo. }\end{array}$ & & & & \\
\hline e. & $\begin{array}{l}\text { Uma parte importante do meu trabalho é garantir que todos os } \\
\text { envolvidos no processo ensino-aprendizagem sejam } \\
\text { considerados co-responsáveis pelo alcance das metas da } \\
\text { escola. }\end{array}$ & & & & \\
\hline f. & $\begin{array}{l}\text { Uma parte importante do meu trabalho é apresentar aos } \\
\text { professores iniciantes as propostas de trabalho existentes na } \\
\text { escola de forma convincente. }\end{array}$ & & & & \\
\hline g. & $\begin{array}{l}\text { Influencio nas decisões sobre esta escola tomadas em um nível } \\
\text { administrativo superior. }\end{array}$ & & & & \\
\hline h. & $\begin{array}{l}\text { É importante para a escola que eu verifique se todos cumprem } \\
\text { as regras. }\end{array}$ & & & & \\
\hline
\end{tabular}




\begin{tabular}{|l|l|l|l|l|}
\hline i. & $\begin{array}{l}\text { É importante para a escola que eu verifique a existência de } \\
\text { falhas erros nos procedimentos administrativos e } \\
\text { pedagógicos. }\end{array}$ & & & \\
\hline j. & $\begin{array}{l}\text { Uma parte importante do meu trabalho é solucionar problemas } \\
\text { relativos a horários e/ou planejamento das aulas. }\end{array}$ & & & \\
\hline k. & $\begin{array}{l}\text { Uma parte importante do meu trabalho é criar uma atmosfera } \\
\text { ordeira na escola. }\end{array}$ & & & \\
\hline I. & $\begin{array}{l}\text { Não tenho forma de saber se os professores estão } \\
\text { desempenhando bem ou mal suas atribuições docentes. }\end{array}$ & & & \\
\hline m. & $\begin{array}{l}\text { Nesta escola, trabalhamos com base nos objetivos definidos } \\
\text { coletivamente e/ou num plano de desenvolvimento da escola. }\end{array}$ & & & \\
\hline n. & Eu defino as metas a serem alcançadas pela equipe escolar. & & & \\
\hline o. & $\begin{array}{l}\text { Eu incentivo que haja uma organização do trabalho voltada para } \\
\text { atividades fomentadas coletivamente nesta escola. }\end{array}$ & & \\
\hline
\end{tabular}

35. ENUMERE EM ORDEM DE IMPORTÂNCIA, AS FUNÇÕES ESCOLARES QUE POSSAM AUXILIAR O PROFESSOR INICIANTE NO DESENVOLVIMENTO DO TRABALHO PEDAGÓGICO:
( ) Professores
( ) Coordenador
( ) Supervisor Pedagógico
( ) Supervisor Administrativo
( ) Orientador Educacional
( ) Vice-Diretor
( ) Diretor

36. ASSINALE ABAIXO AS PRINCIPAIS DIFICULDADES DOS PROFESSORES INICIANTES, OBSERVADAS POR VOCÊ AO LONGO DOS ANOS DE GESTÃO ESCOLAR:

\begin{tabular}{|l|l|l|l|}
\hline & Indisciplina & & Salário \\
\hline & Domínio de turma & & Rotina \\
\hline & Insegurança com Conteúdos & & Falta de acolhimento dos pares \\
\hline Tempo & & Ausência de apoio da gestão \\
\hline & Pais & & Metodologia de aprendizagem \\
\hline Avaliação & & Orientação \\
\hline Conflito teoria e prática & & $\begin{array}{l}\text { Ausência de recursos didáticos- } \\
\text { pedagógicos }\end{array}$ \\
\hline & Estrutura física & & Falta de acolhimento \\
\hline & Conhecimento Pedagógico & & Conhecimento didático \\
\hline
\end{tabular}


37. DESCREVA COMO VOCÊ ACREDITA QUE DEVA SER REALIZADO O PROCESSO DE INSERÇÃO DO PROFESSOR INICIANTE NO TRABALHO DOCENTE.

38. QUEM REALIZA A AVALIAÇÃO DO PROFESSOR EM "ESTÁGIO PROBATÓRIO"? (No caso de ser uma equipe, assinale todos os participantes.)
( ) Professores
( ) Coordenador
( ) Supervisor Pedagógico
( ) Supervisor Administrativo
( ) Orientador Educacional
( ) Vice-Diretor
( ) Diretor
( ) Todos juntos
( ) Outros. Especifique:

39. POR MEIO DE QUE INSTRUMENTO SE REALIZA A AVALIAÇÃO DE ESTÁGIO PROBATÓRIO DOS PROFESSORES, EM SUA ESCOLA?
( ) Auto avaliação
( ) Avaliação discente
( ) Entrevista
( ) Formulário padrão da SEEDF
( ) Plano de trabalho
( ) Questionário
( ) Relatório
( ) Reunião colegiada
( ) Outros. Especifique:

40. VOCÊ PERCEBE RELAÇÃO DIRETA ENTRE PROCESSO DE INSERÇÃO DE PROFESSORES INICIANTES NO TRABALHO DOCENTE E A FUNÇÃO DE GESTOR ESCOLAR?

( ) Não （） Sim

Justifique sua

resposta. 
41. LEIA A AFIRMATIVA: "Muito do processo de socialização do professor iniciante com o trabalho docente, depende da equipe gestora". AGORA ASSINALE ABAIXO:

( ) Discordo plenamente

( ) Discordo parcialmente

( ) Indiferente

( ) Concordo parcialmente

( ) Concordo plenamente

Comente sua resposta:

Obrigada pela sua colaboração!!! 


\section{APÊNDICE 2 - QUESTIONÁRIO DOS PROFESSORES}

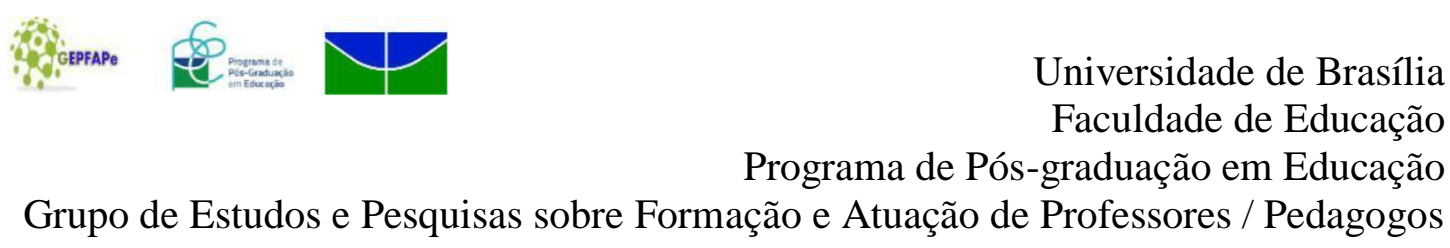

Caro(a) professor(a) ${ }^{1}$,

Pedimos a gentileza de colaborar com nossa pesquisa respondendo a este questionário que tem como objetivos identificar e analisar quais são as dificuldades, descobertas e conquistas do trabalho docente dos professores iniciantes no cotidiano das escolas. As informações fornecidas por vocês terão o anonimato garantido e serão fundamentais para o andamento da pesquisa.

Solicitamos que informe seu nome:

idade: anos, curso

de graduação: tempo de carreira efetivo Secretaria de

Educação: a escola em que trabalha:

telefone: , para que possamos entrar em contato posteriormente.

Esses dados serão restritos e confidenciais.

Código do questionário:

Você poderia nos conceder uma entrevista posteriormente? Sim ( ) Não ( ）

Agradecemos sua disponibilidade e nos colocamos à sua disposição para quaisquer esclarecimentos.

Profa. Dra. Kátia Augusta Curado Pinheiro Cordeiro da Silva E-mail: katiacurado@unb.br Fone: (61) 9879-5649

Profa. Dra. Shirleide Pereira da Silva Cruz E-mail: shirleidesc@ gmail.com Fone: (61) 9277-0504

${ }^{1}$ Com a finalidade de tornar a leitura mais dinâmica e menos cansativa, utilizaremos a norma padrão-culta da língua portuguesa ao tratar do professor da Educação Básica, cientes de que a maioria do professorado é do sexo feminino. 
Código do questionário:

\section{QUESTIONÁRIO}

\section{I - IDENTIFICAÇÃO}

1. Idade:

\begin{tabular}{|c|c|}
\hline & \multirow{3}{*}{$\begin{array}{l}\text { De } 36 \text { a } 40 \text { anos } \\
\text { De } 41 \text { a } 45 \text { anos }\end{array}$} \\
\hline \multirow{2}{*}{$\begin{array}{l}\text { Até } 20 \text { anos } \\
\text { De } 21 \text { a } 25 \text { anos }\end{array}$} & \\
\hline & \\
\hline De 26 a 30 anos & De 46 a 50 anos \\
\hline De 31 a 35 anos & Mais de 51 anos \\
\hline
\end{tabular}

2. Sexo:

$\square$ Feminino $\square$ Masculino

3. Estado Civil:

\begin{tabular}{|l|l}
\hline & $\begin{array}{l}\text { Casado } \\
\text { Divorciado } \\
\text { Solteiro }\end{array}$
\end{tabular}$\quad \square$ União estável

4. Número de filhos:

5. Você possui algum tipo de deficiência?

Não

Sim

\begin{tabular}{|l|c|c|c|c|c|c|}
\hline \multirow{2}{*}{ ITENS } & \multirow{2}{*}{$\begin{array}{c}\text { Em } \\
\text { andamento }\end{array}$} & \multirow{2}{*}{$\begin{array}{c}\text { Ano de } \\
\text { Conclusão }\end{array}$} & \multicolumn{5}{c|}{ Marque um "X" } \\
\cline { 4 - 8 } & & & Pública & Privada & Presencial & A distância \\
\hline Ensino Médio & & & & & & \\
\hline Magistério & & & & & & \\
\hline Graduação & & & & & & \\
\hline Especialização & & & & & & \\
\hline Mestrado & & & & & & \\
\hline Doutorado & & & & & & \\
\hline
\end{tabular}

7. Você ingressou na profissão docente com qual idade?

8. Quantos anos você tem de profissão docente?

9. Quanto tempo você tem como professor efetivo na Secretaria de Educação?

continua... 
10. Identifique sua faixa salarial:

\begin{tabular}{|l|l|l|}
\hline & Até 2 salários mínimos & Até $\mathrm{R} \$ 1.576,00$ \\
\hline & De 2 a 4 salários mínimos & De $\mathrm{R} \$ 1.576,00$ a $\mathrm{R} \$ 3.152,00$ \\
\hline & De 4 a 10 salários mínimos & De $\mathrm{R} \$ 3.152,00$ a $\mathrm{R} \$ 7.880,00$ \\
\hline & De 10 a 20 salários mínimos & De $\mathrm{R} \$ 7.880,00$ a $\mathrm{R} \$ 15.760,00$ \\
\hline & Acima de 20 salários mínimos & Acima de $\mathrm{R} \$ 15.760,00$ \\
\hline
\end{tabular}

11. Identifique sua renda familiar mensal:

\begin{tabular}{|l|l|l|}
\hline & Até 2 salários mínimos & Até $\mathrm{R} \$ 1.576,00$ \\
\hline & De 2 a 4 salários mínimos & De $\mathrm{R} \$ 1.576,00$ a $\mathrm{R} \$ 3.152,00$ \\
\hline & De 4 a 10 salários mínimos & De $\mathrm{R} \$ 3.152,00$ a $\mathrm{R} \$ 7.880,00$ \\
\hline & De 10 a 20 salários mínimos & De $\mathrm{R} \$ 7.880,00$ a $\mathrm{R} \$ 15.760,00$ \\
\hline & Acima de 20 salários mínimos & Acima de $\mathrm{R} \$ 15.760,00$ \\
\hline
\end{tabular}

\section{II - ESCOLHA PROFISSIONAL}

12. Por que escolheu a profissão docente? Marque até duas (2) alternativas.

\begin{tabular}{|c|c|}
\hline \multirow{7}{*}{$\begin{array}{l}\text { Acessibilidade ao curso } \\
\text { Falta de opção } \\
\text { Gostar de crianças } \\
\text { Identidade com a área do conhecimento a ser ensinada } \\
\text { Influência da família } \\
\text { Influência de amigos }\end{array}$} & \multirow{3}{*}{$\begin{array}{l}\text { Interesse pela profissão } \\
\text { Oferta de emprego }\end{array}$} \\
\hline & \\
\hline & \\
\hline & Questão financeira \\
\hline & Realização pessoal \\
\hline & Vocação \\
\hline & Outro? \\
\hline
\end{tabular}

13. Possui graduação em outra área?

Não. $\square$ Sim. Qual?

14. Deseja fazer outro curso de graduação?

\begin{tabular}{l}
$\begin{array}{l}\square \text { Não. } \square \text { Não sei } \\
\\
\text { Por quê? }\end{array}$ \\
\hline
\end{tabular}

15. Pretende prestar outro concurso público para sair da Secretaria da Educação?

Não. Não sei $\square$ Sim. Por quê? 


\section{III - INGRESSO NA CARREIRA}

16. Quando você se apresentou à escola, quem o recebeu?

\begin{tabular}{|l|l|}
\hline & Coordenador \\
\hline & Diretor \\
\hline & Orientador \\
\hline & Professores
\end{tabular}

\begin{tabular}{|l|l}
\hline & Secretário Escolar \\
\hline Supervisor \\
Vice-diretor \\
\hline Outro?
\end{tabular}

17. Indique o nível de receptividade ao se apresentar na escola:

\begin{tabular}{|l|l|l|l|l|l|l|}
\hline \multicolumn{1}{|c|}{ ITENS } & Péssima & Ruim & Regular & Boa & Ótima & $\begin{array}{c}\text { Não se } \\
\text { aplica }\end{array}$ \\
\hline Pela coordenação & & & & & & \\
\hline Pelo diretor & & & & & & \\
\hline Pelo orientador & & & & & & \\
\hline Pelo secretário escolar & & & & & & \\
\hline Pelo supervisor & & & & & & \\
\hline Pelo vice-diretor & & & & & & \\
\hline Pelos alunos & & & & & \\
\hline Pelos funcionários administrativos & & & & & & \\
\hline Pelos professores & & & & & \\
\hline
\end{tabular}

18. No seu primeiro dia na escola, você assumiu a sala de aula?

( ) Não. O que você fez?

( ) Sim. Foi-lhe repassada alguma instrução ou atividade planejada para execução da aula?

19. Marque um " $X$ " nas respostas que correspondem às informações que lhes foram repassadas no momento da sua chegada.

\begin{tabular}{|l|l|}
\hline & Estrutura física da escola (ambientes, material pedagógico, materiais didáticos de apoio...) \\
\hline & $\begin{array}{l}\text { Estrutura pedagógica (planejamento, formas de avaliação, PPP, encontros pedagógicos, } \\
\text { documentos, currículo...) }\end{array}$ \\
\hline & Serviços de apoio ao professor e ao aluno \\
\hline $\begin{array}{l}\text { Regras funcionais (horário, regimento, procedimentos administrativos, pedagógicos, } \\
\text { disciplinares...) }\end{array}$ \\
\hline $\begin{array}{l}\text { Rotinas (calendário escolar, diários de classe, onde encontrar e solicitar materiais, } \\
\text { intervalos...) }\end{array}$ \\
\hline O perfil da turma que iria assumir \\
\hline Nenhuma das alternativas \\
\hline Outros. Qual? \\
\hline
\end{tabular}


20. Quais as funções escolares que o auxiliam no início de carreira no desenvolvimento do trabalho pedagógico? (Enumere de 1 a 7 , considerando 1 para menor valor e 7 para maior valor).

\begin{tabular}{|l|l|l|l|}
\hline & Coordenador & & Secretário Escolar \\
\hline & Diretor & Supervisor \\
\hline & Orientador & & Vice-diretor \\
\hline & Professores & & Outro? \\
\hline
\end{tabular}

21. Sobre o Estágio probatório você pode afirmar que:

\begin{tabular}{|l|c|c|}
\hline \multicolumn{1}{|c|}{ ITENS } & SIM & NÃO \\
\hline A avaliação foi realizada anualmente? & & \\
\hline A avaliação foi realizada mensalmente? & & \\
\hline A avaliação foi realizada semestralmente? & & \\
\hline Ainda não foi avaliado? & & \\
\hline Desconhece que foi avaliado? & & \\
\hline Desconhece que será avaliado? & & \\
\hline Esta avaliação foi coletiva? & & \\
\hline Esta avaliação foi formativa? & & \\
\hline Esta avaliação foi individual? & & \\
\hline Esta avaliação foi justa? & & \\
\hline Foi realizada por seu coordenador? & & \\
\hline Foi realizada por seu diretor? & & \\
\hline Foi realizada por seus pares? & \\
\hline Sentiu-se constrangido de alguma forma? & \\
\hline
\end{tabular}

22. Como se sentiu no processo de avaliação no estágio probatório?

23. Quais os instrumentos utilizados no processo de avaliação?

\begin{tabular}{|l|l}
\hline & Auto Avaliação \\
\hline & Avaliação discente \\
Entrevista \\
Formulário padrão da SEDF \\
Não sei
\end{tabular}

\begin{tabular}{|l|l|}
\hline & Plano de trabalho \\
\cline { 1 - 2 } & Questionário \\
Relatório \\
Reunião Colegiada \\
\cline { 1 - 2 } Outros
\end{tabular}




\section{V - APRENDIZAGEM DA DOCÊNCIA}

24. Escolha, para cada item, a resposta que indica o nível de importância para a aprendizagem da docência:

\begin{tabular}{|c|c|c|c|c|}
\hline \multirow[b]{2}{*}{ ITENS } & \multicolumn{3}{|c|}{ IMPORTANTE } & \multirow[b]{2}{*}{ 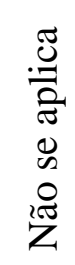 } \\
\hline & 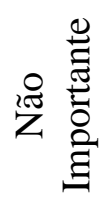 & 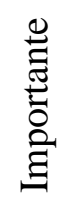 & 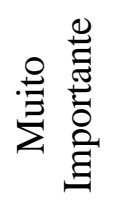 & \\
\hline \multicolumn{5}{|l|}{ A relação professor-aluno no curso de graduação } \\
\hline \multicolumn{5}{|l|}{ A relação professor-aluno no ensino fundamental } \\
\hline \multicolumn{5}{|l|}{ A relação professor-aluno no ensino médio } \\
\hline \multicolumn{5}{|l|}{ A vivência de extensão no ensino superior } \\
\hline \multicolumn{5}{|l|}{ As práticas de estágio } \\
\hline \multicolumn{5}{|l|}{ As práticas dos professores no Ensino Superior } \\
\hline \multicolumn{5}{|l|}{ Programa de iniciação à docência } \\
\hline \multicolumn{5}{|l|}{ Um professor marcante na trajetória escolar } \\
\hline \multicolumn{5}{|l|}{ A interação com os movimentos sociais } \\
\hline \multicolumn{5}{|l|}{ A avaliação do estágio probatório } \\
\hline \multicolumn{5}{|l|}{ A experiência de docência } \\
\hline \multicolumn{5}{|l|}{ A formação continuada } \\
\hline \multicolumn{5}{|l|}{ A interação com o sindicato } \\
\hline \multicolumn{5}{|c|}{$\begin{array}{l}\text { A relação com a comunidade escolar e os familiares dos } \\
\text { alunos }\end{array}$} \\
\hline \multicolumn{5}{|l|}{ A vivência de extensão na formação continuada } \\
\hline \multicolumn{5}{|l|}{ O apoio da coordenação } \\
\hline \multicolumn{5}{|l|}{ O contato com professores mais experientes } \\
\hline \multicolumn{5}{|l|}{ O planejamento coletivo } \\
\hline \multicolumn{5}{|l|}{ O Projeto Político Pedagógico } \\
\hline \multicolumn{5}{|l|}{ O trabalho coletivo na escola } \\
\hline \multicolumn{5}{|l|}{ A experiência como monitor } \\
\hline \multicolumn{5}{|l|}{ A formação inicial } \\
\hline \multicolumn{5}{|l|}{ A iniciação científica } \\
\hline A participação em eventos/cursos acadêmicos & & & & \\
\hline
\end{tabular}

Continua... 


\section{VI - DIFICULADADES E DESCOBERTAS}

25. Escolha a resposta na escala que indica o seu nível de dificuldade na área descrita no respectivo item.

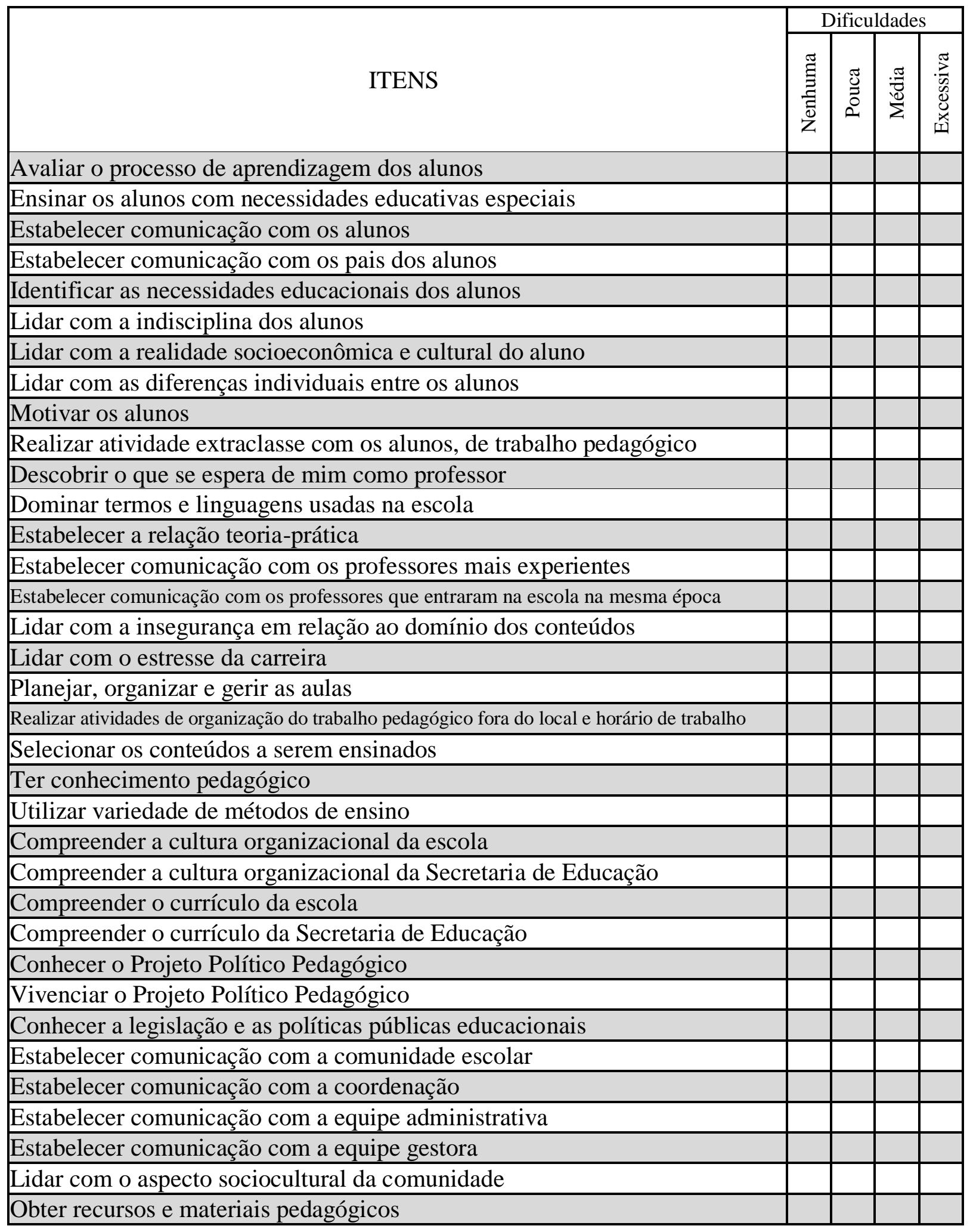


Participar das assembleias e ações do sindicato

Participar das discussões de grupo com os pares

Preencher os formulários e fichas administrativos

Trabalhar com a estrutura física disponível

26. Como você enfrentou suas dificuldades?

27. Quais foram suas maiores descobertas/satisfação no início da carreira docente? (Escolha a resposta na escala que indica o seu nível em cada área descrita no respectivo item)

\begin{tabular}{|c|c|c|c|c|}
\hline \multirow{2}{*}{ ITENS } & \multicolumn{4}{|c|}{ Descobertas } \\
\hline & $\frac{\mathfrak{\Xi}}{\Xi}$ & $\begin{array}{l}\tilde{0} \\
\stackrel{0}{0} \\
.\end{array}$ & 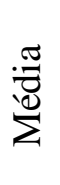 & 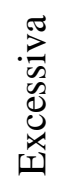 \\
\hline \multicolumn{5}{|l|}{ A equipe de trabalho } \\
\hline \multicolumn{5}{|l|}{ A relação professor-aluno } \\
\hline \multicolumn{5}{|l|}{ Autonomia } \\
\hline \multicolumn{5}{|l|}{ O carinho dos alunos } \\
\hline \multicolumn{5}{|l|}{$\mathrm{O}$ prazer de lidar com o conhecimento } \\
\hline \multicolumn{5}{|l|}{ O prazer em ensinar } \\
\hline \multicolumn{5}{|l|}{ O reconhecimento social } \\
\hline \multicolumn{5}{|l|}{ O trabalho coletivo } \\
\hline \multicolumn{5}{|l|}{ Participação dos eventos da comunidade } \\
\hline \multicolumn{5}{|l|}{ Participação dos eventos escolares } \\
\hline \multicolumn{5}{|l|}{ Planejamento das aulas } \\
\hline \multicolumn{5}{|l|}{ Possibilidade da criatividade pedagógica } \\
\hline \multicolumn{5}{|l|}{ Possibilidades de formação continuada } \\
\hline \multicolumn{5}{|l|}{ Realização Pessoal } \\
\hline \multicolumn{5}{|l|}{ Relação com a gestão } \\
\hline \multicolumn{5}{|l|}{ Relação com o saber/aprender } \\
\hline \multicolumn{5}{|l|}{ Relação com os outros funcionários da escola } \\
\hline \multicolumn{5}{|l|}{ Relação com os pares } \\
\hline \multicolumn{5}{|l|}{ Rotina da escola } \\
\hline \multicolumn{5}{|l|}{ Direitos trabalhistas } \\
\hline \multicolumn{5}{|l|}{ Flexibilidade da carga horária } \\
\hline \multicolumn{5}{|l|}{ Oferta do mercado de trabalho } \\
\hline \multicolumn{5}{|l|}{ Participação política } \\
\hline \multicolumn{5}{|l|}{ Plano de carreira } \\
\hline \multicolumn{5}{|l|}{ Salário } \\
\hline \multicolumn{5}{|l|}{ Teor político da profissão } \\
\hline O reconhecimento social & & & & \\
\hline
\end{tabular}


28. Quais sugestões você daria para a recepção do professor em início de carreira?

29. Quais sugestões você daria para quem está iniciando a carreira?

\section{VII - ATUAÇÃO PROFISSIONAL}

30. Marque um "X" na classificação que se aproxima do nível de satisfação nos itens abaixo:

\begin{tabular}{|l|l|l|l|l|l|}
\hline \multicolumn{1}{|c|}{ ITENS } & Péssima & Ruim & Regular & Boa & Ótima \\
\hline Dinâmica da sala de aula & & & & & \\
\hline Seu trabalho docente & & & & & \\
\hline Sua escola & & & & & \\
\hline Sua relação com a equipe gestora & & & & & \\
\hline Sua relação com o sindicato & & & & & \\
\hline Sua relação com os pares & & & & & \\
\hline Suas atividades pedagógicas & & & & & \\
\hline
\end{tabular}

31. Quais os instrumentos utilizados no processo de avaliação?

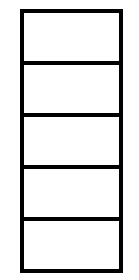

Autonomia

Carga horária

Flexibilidade da carga horária

Oferta do mercado de trabalho

Plano de carreira

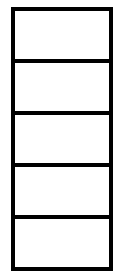

Realização Pessoal

Relação interpessoal

Rotina

Salário

Outros

32. Qual(is) é(são) o(s) aspecto(os) negativo(s) do seu trabalho?

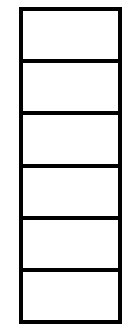

Competição entre os pares

Desgaste emocional

Desgaste físico

Falta de autonomia

Flexibilidade da carga horária

Oferta do mercado de trabalho

\begin{tabular}{|l|l|}
\hline & $\begin{array}{l}\text { Plano de carreira } \\
\text { Produtividade }\end{array}$ \\
& Relação interpessoal \\
& Rotina \\
\cline { 1 - 1 } Salário \\
\cline { 1 - 1 } Outros
\end{tabular}


33. Como você percebe o nível de reconhecimento social em relação ao profissional professor?

\begin{tabular}{|l|l}
$y$ & $\begin{array}{l}\text { Muito bom } \\
\text { Bom } \\
\text { Médio }\end{array}$ \\
\cline { 1 - 2 } &
\end{tabular}

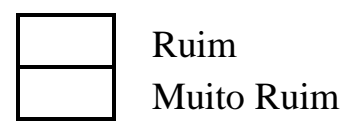

34. Sobre sua experiência profissional:

a) Você atuou (ou atua há) quantos anos no Ensino Público?

b) Você atuou (ou atua há) quantos anos no Ensino Privado?

c) Qual o nível de ensino em que atua?

d) Qual a modalidade de ensino?

e) Qual a carga horária de trabalho?

\section{VIII - ESPAÇO ESCOLAR}

35. Escolha, para cada item, a resposta que indica o nível de importância e satisfação para cada respectivo item.

\begin{tabular}{|c|c|c|c|c|c|c|c|c|}
\hline \multirow[b]{2}{*}{ ITENS } & \multicolumn{5}{|c|}{ Importância } & \multicolumn{3}{|c|}{ Satisfação } \\
\hline & 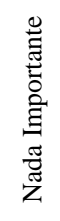 & 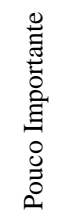 & 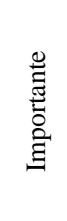 & 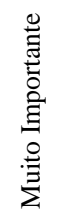 & 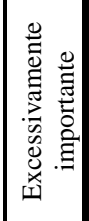 & 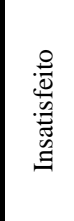 & 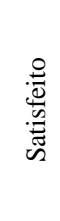 & 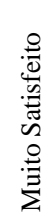 \\
\hline $\begin{array}{l}\text { A forma de trabalhar do colega iniciante contribuiu para a } \\
\text { construção de sua prática docente }\end{array}$ & & & & & & & & \\
\hline $\begin{array}{l}\text { As atividades de acompanhamento da equipe gestora } \\
\text { refletiram na sua prática docente }\end{array}$ & & & & & & & & \\
\hline $\begin{array}{l}\text { As condições materiais de trabalho que encontrou na } \\
\text { escola em que iniciou a carreira }\end{array}$ & & & & & & & & \\
\hline $\begin{array}{l}\text { As relações pessoais que estabelece com os colegas da } \\
\text { escola que atua }\end{array}$ & & & & & & & & \\
\hline $\begin{array}{l}\text { A recepção pelos colegas ao iniciar sua atuação } \\
\text { profissional }\end{array}$ & & & & & & & & \\
\hline Atividades de acompanhamento pela equipe gestora & & & & & & & & \\
\hline $\begin{array}{lllll}\begin{array}{l}\text { Atividades de acompanhamento pela Secretaria de } \\
\text { Educação }\end{array} & & & \\
\end{array}$ & & & & & & & & \\
\hline Atividades de acompanhamento pelo Sindicato & & & & & & & & \\
\hline Atividades de acompanhamento pelos colegas & & & & & & & & \\
\hline Interação e diálogo com a comunidade escolar & & & & & & & & \\
\hline
\end{tabular}




\begin{tabular}{|l|l|l|l|l|l|l|l|l|}
\hline Interação e diálogo com os familiares dos alunos & & & & & & & & \\
\hline O ambiente da escola que você iniciou sua carreira & & & & & & & & \\
\hline $\begin{array}{l}\text { As relações profissionais que estabelece com os colegas } \\
\text { da escola que atua }\end{array}$ & & & & & & & \\
\hline A recepção pela gestão ao iniciar sua atuação profissional & & & & & & & & \\
\hline $\begin{array}{l}\text { A recepção pelo Sindicato ao iniciar sua atuação } \\
\text { profissional }\end{array}$ & & & & & & & & \\
\hline $\begin{array}{l}\text { A recepção pela Secretaria de Educação ao iniciar } \\
\text { sua atuação profissional }\end{array}$ & & & & & & & & \\
\hline
\end{tabular}

\section{IX - DESENVOLVIMENTO PROFISSIONAL}

36. Escolha, para cada item, a resposta que indica o nível de importância que você considera para o seu desenvolvimento profissional.

\begin{tabular}{|c|c|c|c|c|c|c|c|c|}
\hline \multirow[b]{2}{*}{ ITENS } & \multicolumn{5}{|c|}{ Importância } & \multicolumn{3}{|c|}{ Satisfação } \\
\hline & 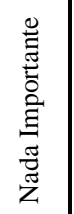 & 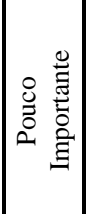 & 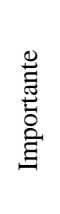 & 至 & 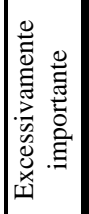 & 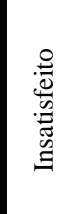 & 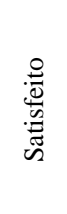 & 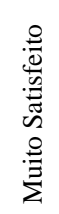 \\
\hline A formação continuada & & & & & & & & \\
\hline A formação na pós-graduação (especialização) & & & & & & & & \\
\hline A formação na pós-graduação (mestrado) & & & & & & & & \\
\hline A formação na pós-graduação (doutorado) & & & & & & & & \\
\hline A participação em atividades da comunidade & & & & & & & & \\
\hline A troca com os pares & & & & & & & & \\
\hline $\begin{array}{l}\text { As atividades diárias de planejamento, avaliação e } \\
\text { docência }\end{array}$ & & & & & & & & \\
\hline As coordenações coletivas & & & & & & & & \\
\hline As coordenações individuais & & & & & & & & \\
\hline As reuniões coletivas da escola & & & & & & & & \\
\hline Cursos de extensão & & & & & & & & \\
\hline Cursos livres & & & & & & & & \\
\hline Encontros e congressos científicos & & & & & & & & \\
\hline Estudos individuais & & & & & & & & \\
\hline Os eventos e cursos promovidos pela escola que atua & & & & & & & & \\
\hline $\begin{array}{l}\text { Os eventos e cursos promovidos pela Secretaria de } \\
\text { Educação }\end{array}$ & & & & & & & & \\
\hline
\end{tabular}




\begin{tabular}{|l|l|l|l|l|l|l|l|l|}
\hline Os eventos e cursos promovidos pelo sindicato & & & & & & & & \\
\hline Participação em grupos de estudos e pesquisas & & & & & & & & \\
\hline
\end{tabular}

\section{X - VIDA SOCIAL}

37. Enumere as atividades culturais das quais participa. Sendo 0 para nenhuma frequência e 4 maior frequência.

\begin{tabular}{|l|l|l|l|l|}
\hline Assistir a filmes & & & & \\
\hline Assistir programas de televisão & & & & \\
\hline Escrever & & & & \\
\hline Frequentar bares & & & & \\
\hline Frequentar biblioteca & & & & \\
\hline Frequentar cafés & & & & \\
\hline Frequentar livraria & & & & \\
\hline Ir a concertos & & & & \\
\hline Ir a espetáculos de dança & & & & \\
\hline Ir a exposições & & & & \\
\hline Ir a museus & & & & \\
\hline Ir a shows & & & & \\
\hline Ir ao cinema & & & & \\
\hline Ir ao circo & & & & \\
\hline Ir ao teatro & & & & \\
\hline Ler jornais e/ou revistas & & & & \\
\hline Ler livros e outros não relacionados ao trabalho & & & & \\
\hline Navegar na internet & & & & \\
\hline Ouvir música & & & & \\
\hline Realizar atividades esportivas & & & & \\
\hline Viajar & & & & \\
\hline Outros & & & \\
\hline
\end{tabular}

\section{XI - VIDA POLÍTICA}

38. Participa de atividades político-sociais:

\begin{tabular}{|l|l|l}
$\square$ & Não. & Sim. Qual(ais)?
\end{tabular}


39. Quando exerce o direito/dever do voto há uma tendência partidária? Marque-a na lista abaixo:

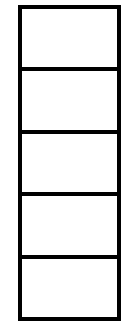

Partidos conservadores

Partidos de esquerda

Partidos vinculados a religiões

Partidos de centro

Partidos ligados à ecologia

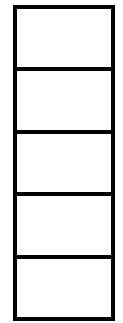

Vota na pessoa do candidato

Vota em branco

Vota nulo

Não vota

Outro?

40. Você é sindicalizado? Justifique sua resposta.

Não

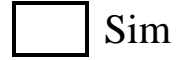

41. Você participou de alguma atividade de recepção aos professores ingressantes promovida pelo sindicato? Comente.

Não

$\operatorname{Sim}$

42. O que você considera importante na atuação do sindicato na categoria de professores? (Enumere de 1 a 9, considerando 1 para menor valor e 9 para maior valor).

\begin{tabular}{|c|}
\hline \\
\hline Apoio médico-psicológico \\
\hline Atividades culturais \\
\hline Espaço de lazer \\
\hline Outro \\
\hline
\end{tabular}

Formação política

Formação continuada/pedagógica

Luta por carreira condições de trabalho e remuneração

Políticas de descontos em serviço

Mediação na relação entre os pares

43. Você percebe o sindicato como entidade representativa dos professores? Justifique.

44. Você considera que as ações desenvolvidas pelo sindicato têm contribuído com a formação e profissionalização de professores?

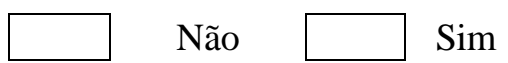

Justifique. 


\section{XI - ASSUMIR A PROFISSÃO DOCENTE}

45. Como foi o momento que você se viu assumindo a profissão docente?

46. Ser professor é

Muito obrigado(a) pela participação! 


\title{
APÊNDICE 3 - ROTEIRO DE ENTREVISTA DOS GESTORES
}

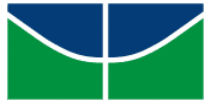 \\ UNIVERSIDADE DE BRASÍLIA \\ FACULDADE DE EDUCAÇÃO \\ PROGRAMA DE PÓS-GRADUAÇÃO EM EDUCAÇÃO
}

ROTEIRO DE ENTREVISTA - (GESTORES)

Nome:

Data: Local:

Duração: às

Perguntas orientadoras:

1. Descreva como você costuma recepcionar os professores iniciantes na escola, durante sua gestão.

2. Você tem protocolo de instruções estabelecido para recepcionar os professores iniciantes, dando-lhe as informações básicas sobre a instituição e o sistema educacional da SEDF? Comente.

3. Quando é identificado dificuldades no desenvolvimento do trabalho docente de professores iniciantes, quais são os procedimentos adotados?

4. Comente sua relação profissional com os professores.

5. Relate algumas dificuldades encontradas por professores iniciantes que você já percebeu durante o seu trabalho de gestor escolar.

6. Comente sua rotina diária distinguindo as atividades administrativas e pedagógicas por você realizadas. 


\title{
APÊNDICE 4 - ROTEIRO DE ENTREVISTA DOS PROFESSORES
}

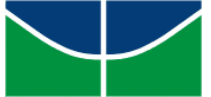 \\ UNIVERSIDADE DE BRASÍLIA \\ FACULDADE DE EDUCAÇÃO \\ PROGRAMA DE PÓS-GRADUAÇÃO EM EDUCAÇÃO \\ ROTEIRO DE ENTREVISTA - (PROFESSORES)
}

Nome:

Data: Local:

Duração: às

\section{Perguntas orientadoras:}

1. Fale sobre suas expectativas quando do encaminhamento para a unidade escolar.

2. Informe quem o recebeu na escola e comente a recepção.

3. Comente quais foram às primeiras informações (procedimentos, regras, diretrizes... - da unidade escolar e do sistema da SEDF) repassadas à você, quando do momento da sua chegada à escola.

4. Comente quais foram as principais dificuldades encontradas e como você buscou resolve-las. Quem o ajudou.

5. Fale sobre a sua relação profissional com a equipe gestora.

6. Relate como você se sentiu nas primeiras aulas em que atuou.

7. Como você se sente hoje em relação a sua atividade profissional e o ambiente escolar? 


\section{ANEXOS}

1. Lei no 957/1995 - Dispõe sobre a gestão democrática da escola pública.

2. Lei no 4.036/2007 - Dispõe sobre a gestão compartilhada nas instituições educacionais.

3. Lei no 4.751/2012 - Dispõe sobre o Sistema de Ensino e a Gestão Democrática de Ensino Público do Distrito Federal.

4. Lei no 5.105/2013 - Reestrutura a Carreira do Magistério Público do Distrito Federal.

5. Portaria no 219/2014 - Dispõe sobre normas para lotação, exercício, remanejamento externo e interno de servidores integrantes da Carreira Magistério Público do Distrito Federal.

6. Ementa do Curso - Integração à Carreira do Magistério Público do DF.

- Educação Infantil/Anos Iniciais

- Anos Finais

- Anos Finais: Área de Linguagens, Códigos e suas Tecnologias

- Ensino Médio e EJA

7. Ementa do Curso - Gestão Escolar Democrática: das Políticas Públicas ao Projeto Político-Pedagógico da Escola. 
Dispõe sobre a Gestão Democrática da Escola Pública e dá outras providências.

O GOVERNADOR DO DISTRITO FEDERAL, Faço saber que a Câmara Legislativa do Distrito Federal decreta e eu sanciono a seguinte Lei:

\section{CAPÍTULO I \\ DOS PRINCÍPIOS DA GESTÃO DEMOCRÁTICA}

Art. $1^{0}$ São princípios da Gestão Democrática do Sistema de Ensino Público do Distrito Federal:

I - livre organização dos segmentos da comunidade escolar em nível de unidade de ensino, no âmbito do Distrito Federal;

II - participação de todos os segmentos das unidades de ensino nos processos e instâncias decisórios, desde que se garanta, nas bases, sua representação democrática e organizada, na forma desta Lei;

III - escolha dos diretores das unidades de ensino, com a participação direta da comunidade, de acordo com o estabelecido nesta Lei;

IV - autonomia das unidades de ensino, no que Ihes couber pela legislação vigente, na gestão pedagógica, administrativa e financeira de seu projeto educativo, sob responsabilidade de um Conselho Deliberativo Escolar, com representação eleita dos quatro segmentos da comunidade escolar: alunos, pais ou responsáveis, professores/especialistas e servidores da carreira de assistência à educação, com presença nata do diretor eleito;

V - organização normativa do sistema, de forma democrática, por meio de um Conselho de caráter consultivo e deliberativo;

VI - participação do Conselho de Educação do Distrito Federal e dos Conselhos Escolares na elaboração do orçamento, considerando o elenco de necessidades e prioridades;

VII - repasse para a Secretaria de Educação, de quinze em quinze dias, dos recursos orçados e dos impostos e transferências arrecadados no período, para manutenção do desenvolvimento do ensino;

VIII - transparência nos mecanismos administrativos e financeiros, em todas as instâncias;

IX - garantia de recursos financeiros proporcionais ao número de alunos e às necessidades da escola, distribuídos diretamente às unidades de ensino para o custeio de suas atividades pedagógicas e administrativas e para investimentos de manutenção com padrão de qualidade estabelecido pelo sistema, com a participação de todos os segmentos da comunidade escolar.

Art. $2^{\circ} \mathrm{A}$ gestão da unidade de ensino será exercida pela Direção e pelo Conselho Escolar, eleitos na forma desta Lei. 
Art. $3^{\circ}$ Aplica-se o disposto nesta Lei às unidades de ensino estruturadas na forma de Cooperativas Educacionais, conforme a Lei no 508, de 22 de julho de 1993.

\section{CAPÍTULO II \\ DO CONSELHO ESCOLAR}

Art. $4^{\circ} \mathrm{Em}$ todas as unidades de ensino público do Distrito Federal e nas conveniadas funcionará um Conselho Escolar, órgão deliberativo máximo da escola, respeitada a legislação vigente, composto de, no mínimo, 5 (cinco) membros e, no máximo, 17 (dezessete) membros.

Art. 50 O Conselho Escolar será composto paritariamente pelos segmentos que integram a comunidade escolar, da seguinte forma: $50 \%$ para pais ou responsáveis e alunos, e $50 \%$ para professores/especialistas e servidores da carreira de assistência à educação.

$\S 10$ O número das representações paritárias e de representantes de cada segmento será definido em Assembléia Geral Escolar, convocada, no mínimo, 30 (trinta) dias antes do início do processo de eleição dos conselheiros, a partir de propostas apresentadas pela direção ou pelos segmentos organizados da comunidade escolar e constantes do editar de convocação da assembléia.

$\S 2^{\circ} \mathrm{O}$ edital de convocação da Assembléia Geral Escolar será elaborado pelo Conselho Escolar, que estabelecerá o quorum mínimo de instalação desta Assembléia.

§ $3^{\circ} \mathrm{Na}$ inexistência de Conselho Escolar, a convocação da Assembléia será feita pelo diretor da unidade de ensino ou por órgão designado pela Secretaria de Educação/Fundação Educacional do Distrito Federal.

Art. $6^{\circ} \mathrm{O}$ Diretor da unidade de ensino integrará o Conselho Escolar como membro nato e, em seu impedimento, será substituído por um membro da Direção.

Art. 70 Nas unidades de ensino onde não houver diretor, o Conselho poderá ser composto por um mínimo de 03 (três) membros.

Art. $8^{\circ}$ Todos os segmentos existentes na comunidade escolar deverão ser representados no Conselho Escolar, assegurada a proporcionalidade de $50 \%$ (cinqüenta por cento) para pais ou responsáveis e alunos e $50 \%$ (cinqüenta por cento) para professores/especialistas e servidores da carreira de assistência à educação.

Parágrafo único. No impedimento de participação do segmento dos alunos, prevista nesta Lei, o percentual de $50 \%$ (cinqüenta por cento) será integrado por representantes de pais ou responsáveis.

Art. 90 A eleição dos representantes dos segmentos da comunidade escolar, bem como de seus suplentes, realizar-se-á na unidade de ensino, em cada segmento, por votação, direta e secreta, uninominalmente ou através de chapas em eleição proporcional, na mesma data, observando o disposto nesta Lei.

Art. 10. Cada segmento organizará sua eleição, conforme as seguintes diretrizes:

I - os eleitores de todos os segmentos constarão de lista elaborada e publicada pela Secretaria da unidade de ensino;

II- o quorum mínimo será de $50 \%$ (cinqüenta por cento) dos eleitores do segmento, com exceção dos pais/responsáveis, que será de 10 (dez por cento); 
II - o quorum mínimo será de cinqüenta por cento dos eleitores do segmento, com exceção dos pais ou responsáveis e dos alunos do curso supletivo, que será de dez por cento.

(ALTERADO - Lei nº 2084, de 29 de setembro de 1998)

III - serão considerados eleitores os alunos maiores de 13 (treze) anos ou de qualquer idade cursando a $6^{\circ}$ série em diante, que tenham tido freqüência superior a $50 \%$ (cinqüenta por cento) das aulas no bimestre anterior e os alunos do ensino supletivo, com qualquer freqüência;

IV - serão eleitores do seu segmento todos os pais, mães ou responsáveis dos alunos;

V - serão eleitores de seus segmentos os integrantes das carreiras de magistério e de assistência à educação, dos quadros efetivo e suplementar, em exercício na unidade de ensino;

VI - os que pertencerem a mais de um segmento poderão votar mais de uma vez, mas só poderão se candidatar por um deles, a seu critério;

VII - na hipótese de qualquer segmento não atingir o quorum, convocar-se-á nova eleição, em prazo definido pelo Conselho.

Art. 11. O mandato dos conselheiros terá duração de 2 (dois) anos, permitindo-se reeleições.

Art. 12. A posse dos membros do Conselho Escolar ocorrerá em até 15 (quinze) dias após as eleições.

$\S 1^{\circ} \mathrm{A}$ posse ao primeiro Conselho Escolar será dada pela Direção da escola e aos seguintes pelo próprio Conselho Escolar.

$\S 2^{\circ} \mathrm{O}$ Conselho Escolar elegerá o seu presidente e o seu secretário.

§ $3^{\circ} \mathrm{O}$ exercício da função de membro do Conselho Escolar terá caráter voluntário, não podendo ser remunerado.

Art. 13. O Conselho Escolar deverá reunir-se ordinariamente 1 (uma) vez por mês e, extraordinariamente, quando for necessário, através de convocação:

I - de seu presidente;

II - do diretor da unidade de ensino;

III - da metade mais I (um) de seus membros.

$\S 1^{\circ} \mathrm{O}$ quorum mínimo para instalação das reuniões do Conselho Escolar será de metade mais um de seus membros.

$\S 2^{\circ}$ Serão válidas as deliberações do Conselho Escolar tomadas por metade mais I (um) dos votos dos presentes à reunião.

§ $3^{\circ} \mathrm{A}$ convocação definida no caput deste artigo, deverá ser feita formalmente, com antecedência mínima de 48 horas. 
Art. 14. A vacância da função de conselheiro dar-se-á por conclusão do mandato, renúncia, aposentadoria, desligamento da unidade de ensino ou destituição.

$\S 1^{\circ} \mathrm{O}$ não comparecimento injustificado de qualquer membro do Conselho Escolar a 3 (três) reuniões ordinárias consecutivas ou a 05 (cinco) alternadas também implicará a vacância da função de conselheiro.

$\S 20$ Ocorrerá destituição de qualquer membro do Conselho Escolar quando assim o decidir a assembléia geral do segmento, convocada pela assinatura de, no mínimo, 20\% (vinte por cento) de seus pares.

Art. 15. Cabe ao suplente:

I - substituir o titular em caso de impedimento;

II - completar o mandato do titular, em caso de vacância.

Parágrafo único. Caso algum segmento da comunidade escolar tenha a sua representação diminuída, o Conselho providenciará a eleição de novo representante com seu respectivo suplente, no prazo máximo de 30 (trinta) dias após a vacância.

Art. 16. Dentre as atribuições do Conselho, além das definidas pelo sistema educacional de ensino, devem constar as seguintes:

I - elaborar seu regimento;

II - adendar, modificar e aprovar o plano administrativo anual, elaborado pela direção da unidade de ensino, sobre a programação e a aplicação dos recursos necessários à manutenção e à conservação da escola;

III - criar e garantir mecanismos de participação efetiva e democrática da comunidade escolar na definição do projeto político-administrativo-financeiro e pedagógico da unidade de ensino;

IV - divulgar, periódica e sistematicamente, informações referentes ao uso dos recursos financeiros, qualidade dos serviços prestados e resultados obtidos;

V - coordenar o processo de discussão para encaminhamento de propostas, elaboração ou alteração do regimento escolar;

VI - convocar a assembléia geral escolar dos segmentos;

VII - propor e coordenar a discussão junto aos segmentos da comunidade escolar e votar alterações no currículo escolar, no que for atribuição da unidade, respeitada a legislação vigente;

VIII - propor e coordenar a discussão junto aos segmentos e votar as alterações metodológicas, didáticas e administrativas da unidade de ensino, respeitada a legislação vigente;

IX - estruturar o calendário escolar e horários, no que competir à unidade de ensino, observada a legislação vigente;

X - fiscalizar a gestão da unidade de ensino. 
Parágrafo único. Na definição das questões pedagógicas, deverão ser resguardados os princípios constitucionais, as normas e as diretrizes do Conselho de Educação do Distrito Federal.

\section{CAPÍTULO III \\ DA DIREÇÃO DA UNIDADE DE ENSINO}

Art. 17. A direção será exercida pelo diretor eleito e por sua equipe técnica.

$\S 1^{0}$ Nas unidades de ensino que, por sua complexidade, requeiram o cargo de vice-diretor, o mesmo será eleito em chapa com o diretor, em conformidade com as exigências previstas nesta Lei.

$\S 2^{\circ} \mathrm{A}$ equipe técnica, obedecendo à modulação de cada unidade de ensino, será submetida à aprovação do Conselho Escolar.

Art. 18. A escolha do diretor da unidade de ensino, bem como o provimento do seu cargo, far-se-á por meio de eleição direta pela comunidade escolar, por voto secreto, sendo proibido o voto por representação.

$\S 10$ Para os efeitos desta Lei, entende-se por comunidade escolar:

a) os alunos matriculados e freqüentes na unidade de ensino, a partir da $6^{a}$ série do ensino fundamental, bem como os alunos com 13 (treze) anos completos ou mais, independentemente da série que estejam cursando;

b) pais, mães ou responsáveis por alunos menores de 13 (treze) anos de idade, devidamente identificados na ficha de matrícula;

c) voluntariamente, pais, mães ou responsáveis pelos demais alunos;

d) integrantes das carreiras de magistério e de assistência à educação dos quadros efetivo e suplementar em exercício na unidade de ensino ou concorrendo a um cargo pela mesma.

$\S 2^{\circ}$ Os votos serão computados de forma paritária entre os segmentos dos professores/especialistas e servidores da carreira de assistência à educação $50 \%$ (cinqüenta por cento) e de pais ou responsáveis e alunos 50\% (cinqüenta por cento).

$\S 3^{\circ}$ A votação somente terá validade se a participação mínima do segmento pais/alunos for de $30 \%$ (trinta por cento) e do segmento professores/servidores atingir $50 \%$ (cinqüenta por cento) do respectivo universo de eleitores.

Art. 19. Poderá inscrever-se para concorrer ao cargo de diretor o servidor da Secretaria de Educação/Fundação Educacional do Distrito Federal concursado, que comprove:

I - pertencer aos quadros da Carreira Magistério Público do Distrito Federal ou da Carreira Assistência à Educação Pública do Distrito Federal;

II - ter experiência no sistema de educação pública do Distrito Federal, na condição de concursado, há, no mínimo, 02 (dois) anos, e estar lotado na Divisão Regional de Ensino da respectiva escola; 
III - ter disponibilidade para o cumprimento do regime de 40 (quarenta) horas semanais, sendo permitidas, apenas, atividades correlatas ou similares, sem prejuízo para a unidade de ensino, previamente aprovadas pelo respectivo Conselho Escolar;

IV - para as escolas que oferecem apenas educação infantil e/ou ensino fundamental até a $4^{a}$ série:

a) ser portador, no mínimo, do curso de $1^{\circ} \mathrm{grau}$, desde que o candidato a vice-diretor possua o curso de graduação, licenciatura curta ou plena com registro no Ministério da Educação e do Desporto que o habilite ao exercício do magistério;

b) ser portador, no mínimo, do curso de $1^{0}$ grau, com registro na Secretaria de Educação que o habilite ao exercício do magistério, quando não está previsto o cargo de vice-diretor.

V - para as demais unidades de ensino da rede pública do Distrito Federal:

a) ser portador, no mínimo, de curso de graduação, desde que o candidato a vice-diretor possua, no mínimo, o curso de graduação, licenciatura curta ou plena, com registro no Ministério da Educação e do Desporto que o habilite ao exercício do magistério;

b) ser portador, no mínimo, de curso de graduação, licenciatura curta ou plena, com registro no Ministério da Educação e do Desporto que o habilite ao exercício do magistério quando não está previsto o cargo de vice-diretor.

Parágrafo único. Não havendo inscrição de candidatos para concorrer ao cargo, caberá à Secretaria de Educação/Fundação Educacional do Distrito Federal designar servidor para exercer o cargo de diretor da unidade de ensino, pelo prazo máximo de 06 (seis) meses e em conformidade com o disposto neste artigo.

Art. 20. Poderão concorrer às eleições os candidatos inscritos que apresentarem e defenderem projetos de gestão em sessão pública.

$\S 1^{0}$ No processo de eleição, o candidato ao cargo de diretor apresentará e defenderá o projeto de gestão, compreendendo os aspectos pedagógico, administrativo e financeiro, perante a comunidade escolar, em sessão pública obrigatória, convocada pelo Conselho Escolar.

$\S 20 \mathrm{Na}$ campanha eleitoral não será permitida a propaganda de caráter político-partidário, a distribuição de brindes ou camisetas, a remuneração ou compensação financeira de qualquer natureza, a configuração de ameaças, coerção ou cerceamento de liberdade, bem como, a publicidade dentro das salas de aula.

Art. 21. Serão considerados eleitos para os cargos de diretor e vice-diretor os candidatos que obtiverem maioria simples do total de votos válidos, conforme o $\S 1^{\circ}$ do art. 18 desta Lei.

Parágrafo único. Em caso de chapa ou candidato único, será necessária a obtenção de $50 \%+1$ (cinqüenta por cento mais um) dos votos apurados.

Art. 22. Os servidores eleitos para os cargos de direção terão mandato de 02 (dois) anos, com direito a reeleição.

$\S 10$ A primeira eleição ocorrerá, em todas as unidades de ensino, nos dias 8 e 9 do mês de dezembro; 
$\S 2^{\circ}$ As demais eleições deverão ocorrer obrigatoriamente na última sexta-feira e sábado do mês de novembro do ano de ocorrência do pleito.

Art. 23. Em caso de vacância do cargo de diretor, assumirá o vice-diretor.

$\S 10$ No impedimento do vice-diretor ou no caso de inexistência de vice-diretor, assumirá a direção um servidor indicado pelo Conselho Escolar, observado o disposto no art. 19 e seus incisos.

$\S 2^{\circ} \mathrm{Na}$ hipótese de a vacância do diretor e de o impedimento do vice-diretor ocorrerem antes de completados dois terços do mandato, nova eleição deverá ser convocada no prazo de 20 (vinte) dias, na forma desta Lei, para mandato complementar.

$\S 3^{\circ}$ No caso da vacância nos demais cargos, o Conselho Escolar apreciará a indicação do substituto.

Art. 24. O regimento eleitoral será único para todo o sistema público de ensino do Distrito Federal, elaborado por Comissão Paritária dos membros da comunidade escolar, a ser designada pela Secretaria de Educação/Fundação Educacional do Distrito Federal.

Parágrafo único. A Comissão Paritária será constituída por 02 (dois) representantes de cada um dos seguintes segmentos:

I - Sindicato dos Professores no DF;

II - Sindicato dos Auxiliares de Administração Escolar no DF;

III - pais ou responsáveis de alunos;

IV - União Metropolitana dos Estudantes Secundaristas de Brasília;

V - Secretaria de Educação ou da Fundação Educacional do Distrito Federal.

Art. 25. O processo eleitoral das unidades de ensino será convocado pela Secretaria de Educação/Fundação Educacional do Distrito Federal por edital público afixado em locais visíveis nas unidades de ensino e coordenado pela comissão eleitoral.

Parágrafo único. Em cada unidade de ensino será constituída uma comissão eleitoral local, composta paritariamente por representantes dos segmentos da comunidade escolar e dos candidatos que, de forma articulada com a Comissão Paritária, conduzirá as eleições.

Art. 26. Compete à Comissão eleitoral:

I - inscrever candidatos;

II - publicar edital com normas de propaganda, lista de candidatos a diretor, data, horário e local de votação, prazos para apuração e recursos;

III - organizar debates entre os candidatos, para que se manifestem quanto a suas posições sobre a educação e propostas de gestão;

IV - nomear, antecipadamente, mesários e escrutinadores e credenciar fiscais indicados pelos respectivos candidatos, bem como providenciar a confecção de cédulas eleitorais; 
V - cumprir e fazer cumprir as normas estabelecidas no regimento eleitoral;

VI - homologar a lista de cada segmento elaborada pela secretaria da unidade de ensino.

Art. 27. A destituição do diretor e do vice-diretor somente poderá ocorrer motivadamente em duas hipóteses:

I - após sindicância, em que lhe seja assegurado amplo direito de defesa, em face da ocorrência de fatos que constituam falta de idoneidade moral, de disciplina, de assiduidade, de dedicação ao serviço ou de eficiência, ou infração funcional, previstos na Lei 8.112/90;

II - após deliberação em assembléia geral da comunidade escolar, convocada pelo Conselho Escolar para este fim específico, a partir de requerimento encaminhado ao mesmo, com assinatura de, no mínimo, 30\% (trinta por cento) dos membros de cada segmento da comunidade escolar.

$\S 1^{\circ} \mathrm{A}$ sindicância de que trata o inciso I far-se-á através de comissão e será concluída no prazo máximo de 30 (trinta) dias.

$\S 20$ O Secretário de Educação do Distrito Federal poderá determinar o afastamento do indiciado durante realização da sindicância, assegurado o retomo às funções caso a decisão final seja pela não destituição.

$\S 3^{\circ} \mathrm{A}$ assembléia de que trata o inciso II deste artigo deverá ser convocada pelo Conselho Escolar em quinze dias após o recebimento do requerimento citado.

$\S 40$ Para instalação da assembléia geral da comunidade escolar a que se refere o inciso II deste artigo, o quorum mínimo deverá ser de $50 \%+1$ (cinqüenta por cento mais um) do número de votantes de cada segmento na eleição da direção em questão.

$\S 5^{\circ} \mathrm{Na}$ assembléia de que trata o inciso II deste artigo será assegurado à direção amplo direito de defesa e, na aferição do resultado da votação que ocorrerá através de voto secreto, observar-se-á a proporcionalidade de $50 \%$ (cinqüenta por cento) dos votos para professores/especialistas e servidores da carreira de assistência à educação e $50 \%$ (cinqüenta por cento) para pais ou responsáveis e alunos.

Art. 28. Para cada unidade de ensino recém instalada, até o provimento da direção na forma desta Lei, serão designados servidores da Secretaria de Educação/Fundação Educacional do Distrito Federal para o exercício do cargo de diretor, pelo prazo máximo de 120 (cento e vinte) dias, respeitando o art. 19 e seus incisos.

$\S 1^{0}$ Expirado o prazo da designação prevista no artigo anterior, proceder-se-á eleição, conforme o previsto nesta Lei.

$\S 200$ disposto no caput deste artigo aplica-se também à unidade de ensino que, em virtude da ampliação do atendimento escolar, vier a comportar o cargo de diretor ou de vice-reitor.

Art. 29. A Secretaria de Educação disporá sobre as medidas a serem adotadas em situação de comprovada inexistência de servidor que atenda às condições previstas no art. 19 desta Lei.

Parágrafo único. O mandato do diretor indicado, conforme o previsto no caput deste artigo, terá duração de 01 (um) ano. Ao final deste prazo, será encaminhada a eleição. 


\section{CAPÍTULO IV \\ DISPOSIÇÕES GERAIS E TRANSITÓRIAS}

Art. 30. Caberá à Secretaria de Educação/Fundação Educacional do Distrito Federal oferecer cursos de qualificação aos diretores e vice-diretores eleitos, de 180 (cento e oitenta) horas, no mínimo, considerando os aspectos político, administrativo, financeiro e pedagógico, com freqüência obrigatória.

Art. 31. As eleições para representantes dos segmentos no Conselho Escolar serão realizadas simultaneamente com a eleição do diretor da unidade de ensino.

§ Io A primeira eleição será convocada pela Secretaria de Educação/Fundação Educacional do Distrito Federal e coordenada por uma Comissão Geral constituída paritariamente por representantes da comunidade escolar, e indicados pelos sindicatos dos trabalhadores em educação (Sindicato dos Professores no Distrito Federal e Sindicato dos Auxiliares de Administração Escolar no Distrito Federal), pelos país ou responsáveis, pela UMESB e pela Secretaria de Educação/Fundação Educacional do Distrito Federal.

$\S 2^{\circ} \mathrm{A}$ primeira eleição do Conselho Escolar poderá ocorrer em até 90 (noventa) dias da posse da direção eleita.

Art. $32^{\circ}$ - Nas quatro últimas semanas que antecedem o pleito os candidatos serão liberados 01 (um) dia por semana:

I - quando ocupante de Cargo em Comissão ou Servidor da Carreira de Assistência à Educação previamente comunicado à Comissão Eleitoral.

II - nos demais casos, a liberação se dará nos dias destinados à Coordenação Pedagógica.

Art. 33. Na primeira eleição, o candidato poderá concorrer à direção de qualquer unidade de ensino, independentemente de sua lotação.

Art. 34. O Governo do Distrito Federal reestruturará, no prazo de 120 (cento e vinte) dias, as unidades de serviços, Centros de Atenção Integral a Criança e ao Adolescente - CAIC'S, após o que se aplicam os efeitos do disposto nesta Lei.

Art. 35. O candidato a diretor ou vice-diretor de unidade de ensino, ocupante de cargo em comissão, deverá afastar-se do mesmo, 48 (quarenta e oito) horas antes da data marcada para as eleições.

Parágrafo único. Os candidatos em regência de classe e em atividades administrativas serão liberados 48 (quarenta e oito) horas antes do pleito eleitoral.

Art. 36. Esta Lei será regulamentada no prazo de 10 (dez) dias, de sua publicação.

Art. 37. Esta Lei entra em vigor na data de sua publicação, revogando-se as disposições contrárias.

Brasília, 22 de novembro de 1995.

$107^{\circ}$ da República e $36^{\circ}$ de Brasília

CRISTOVAM BUARQUE 
DIÁRIO OFICIAL DO DISTRITO FEDERAL

ANO XLI No 207, 26 DE OUTUBRO DE 2007

Dispõe sobre a gestão compartilhada nas instituições educacionais da rede pública de ensino do Distrito Federal e dá outras providências.

O GOVERNADOR DO DISTRITO FEDERAL, FAÇO SABER QUE A CÂMARA LEGISLATIVA DO DISTRITO FEDERAL DECRETA E EU SANCIONO A SEGUINTE LEI:

Art. $1^{\circ}$ - A gestão compartilhada na instituição educacional da rede pública de ensino do Distrito Federal será exercida conforme o disposto no artigo 206, VI, da Constituição Federal, nos artigos $3^{\circ}$, VIII, e 14 da Lei de Diretrizes e Bases da Educação Nacional e no artigo 222 da Lei Orgânica do Distrito Federal.

Art. $\mathbf{2}^{\circ}$ - A gestão compartilhada visa atingir aos seguintes objetivos:

I - implementar e executar as políticas públicas de educação, assegurando a qualidade, a eqüidade e a responsabilidade social de todos os envolvidos;

II - assegurar a transparência dos mecanismos administrativos, financeiros e pedagógicos;

III - otimizar os esforços da coletividade para a garantia da eficiência, eficácia e relevância do plano de trabalho e da proposta pedagógica;

IV - garantir a autonomia das instituições educacionais, no que lhes couber pela legislação vigente, na gestão pedagógica, administrativa e financeira, por meio do Conselho Escolar, de caráter deliberativo;

$\mathrm{V}$ - assegurar o processo de avaliação institucional mediante mecanismos internos e externos, a transparência de resultados e a prestação de contas à comunidade;

VI - assegurar mecanismos de suporte para a utilização, com eficiência, dos recursos descentralizados diretamente às instituições educacionais.

Art. $3^{\circ}$ - A gestão das instituições educacionais será desempenhada pelo diretor e vice-diretor, em consonância com as deliberações do Conselho Escolar, respeitadas as disposições legais.

Parágrafo único. A Secretaria de Estado de Educação oferecerá capacitação aos integrantes do Conselho Escolar para o exercício de suas funções.

Art. $4^{\circ}$ - Os cargos em comissão de diretor e de vice-diretor da instituição educacional serão providos por ato do Governador, após escolha feita pela comunidade escolar, nos termos desta Lei.

Art. $5^{\circ}$ - Para os cargos de diretor e de vice-diretor, o servidor deverá reunir em seu perfil características que possibilitem: I - articular, liderar e executar políticas educacionais, na qualidade de mediador entre essas e a proposta pedagógica e administrativa da instituição educacional, elaborada em conjunto com a comunidade, observadas as diretrizes e metas gerais da política educacional definida para o Governo do Distrito Federal e o uso dos resultados das avaliações internas e externas como subsídio à construção da proposta pedagógica da instituição educacional;

II - compreender os condicionamentos políticos e sociais que interferem no cotidiano escolar para promover a integração e a participação da comunidade escolar, construindo relações de cooperação que favoreçam a formação de redes de apoio e de aprendizagem recíproca;

III - propor e planejar ações que, voltadas para o contexto socioeconômico e cultural em que a escola esteja inserida, incorporem as demandas e os anseios da comunidade local aos propósitos pedagógicos da escola;

IV - valorizar a gestão compartilhada como forma de fortalecimento institucional e de melhoria nos resultados de aprendizagem dos alunos;

V - reconhecer a importância das ações de formação continuada para o aprimoramento dos profissionais que atuam na instituição educacional, criando mecanismos que favoreçam o seu desenvolvimento;

VI - cuidar para que as ações de formação continuada se traduzam efetivamente em contribuição ao enriquecimento da prática pedagógica em sala de aula e à melhoria da aprendizagem, com ênfase no acesso, na permanência e no sucesso do aluno;

VII - acompanhar e avaliar o desenvolvimento da proposta pedagógica e os indicadores de aprendizagem, os resultados das avaliações externas e os indicadores de desempenho divulgados pelo Instituto Nacional de Estudos e Pesquisas Educacionais Anísio Teixeira - INEP, do Ministério da Educação - MEC, com vistas à melhoria do desempenho da instituição educacional;

VIII - conhecer os princípios e as diretrizes da administração pública e incorporá-los à prática gestora no cotidiano da administração escolar.

Art. $6^{\circ}$ - Poderão inscrever-se no processo seletivo para os cargos de diretor e de vice-diretor servidores com carga horária de 40 (quarenta) horas semanais e que atendam, cumulativamente, aos seguintes requisitos:

I - pertencer ao Quadro de Pessoal do Distrito Federal, integrante da Carreira Magistério Público do Distrito Federal, com lotação na Secretaria de Estado de Educação, ou integrar o Quadro de Pessoal Inativo da Carreira Magistério Público do Distrito Federal, exceto se aposentado compulsoriamente ou por invalidez permanente; 
II - ter, no mínimo, 3 (três) anos, em períodos contínuos ou alternados, computados em regência de classe, coordenação pedagógica, cargo de diretor, de vice-diretor ou de assistente, atividade de orientação educacional em instituição educacional da rede pública do Distrito Federal;

III - ser licenciado em qualquer área de conhecimento, preferencialmente com especialização ou aperfeiçoamento em Gestão da Escola Pública;

IV - não ter sido apenado em processo administrativo disciplinar nos 3 (três) anos anteriores à data da indicação para o cargo.

Parágrafo único. A candidatura a cargo de diretor e de vice-diretor fica restrita a uma única instituição educacional pertencente à rede pública do Distrito Federal, desde que nela já tenha atuado.

Art. $7^{\circ}$ - O processo seletivo para indicação de candidatos aos cargos de diretor e de vice-diretor constará das seguintes etapas:

I - etapa I: avaliação do conhecimento de gestão escolar e análise de títulos;

II - etapa II: elaboração e apresentação do plano de trabalho;

III - etapa III: escolha pela comunidade escolar.

$\S 1^{\circ} \mathrm{A}$ etapa I, de avaliação individual, será de caráter eliminatório, assegurado o direito de recurso à comissão de que trata 0 art. 11.

$\S 2^{\circ}$ Os candidatos aos cargos de diretor e vice-diretor que obtiverem $70 \%$ (setenta por cento) de aproveitamento no somatório dos pontos obtidos na avaliação do conhecimento de gestão escolar e na análise individual de títulos passarão à etapa II.

$\S 3^{\circ} \mathrm{Na}$ divulgação dos resultados da etapa I, será utilizado o termo equipe selecionada.

Art. $\mathbf{8}^{\circ}$ - A avaliação do conhecimento de gestão escolar, na etapa I, será realizada por prova objetiva, abrangendo requisitos básicos de gestão administrativa, pedagógica, financeira e conhecimentos sobre legislação educacional, abrangendo os conteúdos constantes do Anexo I desta Lei.

Parágrafo único. Considerar-se-ão aptos a continuar no processo seletivo os candidatos aos cargos de diretor e vicediretor que obtiverem conceito satisfatório igual ou superior a 60 (sessenta) pontos de aproveitamento na prova objetiva, considerando-se a média aritmética das notas alcançadas individualmente, na forma a ser regulamentada pela comissão de que trata 0 art. 11.

Art. $9^{\circ}$ - A análise de títulos, na etapa I, constará da avaliação do curriculum vitae, conforme Anexo II desta Lei.

$\S 1^{\circ} \mathrm{Na}$ análise de títulos, os itens que excederem o valor máximo de pontos estabelecido no Anexo II não serão computados.

$\S 2^{\circ}$ Somente serão admitidos certificados de cursos de graduação, especialização, mestrado e doutorado reconhecidos pelo órgão competente e emitidos por instituições de ensino credenciadas.

$\S 3^{\circ} \mathrm{A}$ certificação de curso realizado no exterior somente será admitida quando devidamente averbada nos termos da legislação brasileira.

Art. 10 - Na etapa II, os candidatos a cargo de diretor e vice-diretor selecionados na etapa I passarão a ser denominados equipe, a qual apresentará o plano de trabalho para a instituição educacional escolhida.

$\S 1^{\circ}$ No plano de trabalho, a ser formulado nos termos do Anexo III desta Lei, a equipe concorrente deverá apresentar soluções factíveis a eventuais problemas detectados, após prévia avaliação da instituição educacional.

$\S 2^{\circ} \mathrm{O}$ plano de trabalho, a ser apresentado à comunidade em audiência pública obrigatória convocada pelo Conselho Escolar, a partir de calendário previamente aprovado pela Secretaria de Estado de Educação, conterá aspectos pedagógicos, administrativos e financeiros e não será objeto de pontuação.

Art. 11 - O processo seletivo para escolha de diretor e vice-diretor será conduzido por comissões central, regionais e locais, a serem designadas pelo Secretário de Estado de Educação do Distrito Federal, com a participação das entidades representativas das Carreiras Magistério Público do Distrito Federal e Assistência à Educação do Distrito Federal, do Conselho de Educação do Distrito Federal e da Subsecretaria de Educação Básica.

Parágrafo único. Fica assegurada a participação do Conselho Escolar na comissão local.

Art. 12 - Os candidatos selecionados participarão do Programa de Capacitação à Gestão Compartilhada, promovido pela Secretaria de Estado de Educação do Distrito Federal, segundo as diretrizes da política educacional da Secretaria de Estado de Educação do Distrito Federal e do Ministério da Educação.

$\S 1^{\circ}$ Será exigida dos participantes a freqüência mínima de $75 \%$ (setenta e cinco por cento) da carga horária do Programa de Capacitação.

$\S 2^{\circ} \mathrm{O}$ Programa de Capacitação visa uniformizar a gestão escolar, respeitadas as normas legais e as peculiaridades da instituição educacional, e subsidiar a elaboração coletiva da proposta pedagógica.

Art. 13 - Na etapa III, a escolha da equipe pela comunidade escolar será realizada nas instituições educacionais, em conformidade com as regras e o cronograma divulgados pela comissão citada no art. 11 desta Lei.

Parágrafo único. A comunidade escolar, por votação, escolherá a equipe que julgar com melhores condições para exercer a gestão compartilhada da instituição educacional, nos termos do art. $4^{\circ}$ desta Lei.

Art. 14 - Durante o processo seletivo, não serão permitidos a propaganda de caráter político-partidário, a distribuição de brindes ou camisetas, a remuneração ou compensação financeira de qualquer natureza, a prática de ato que configure ameaça, a coerção ou o cerceamento de liberdade e a publicidade dentro do ambiente escolar.

Art. 15 - Poderão votar no processo de escolha: 
I - servidores da Carreira Magistério Público do Distrito Federal e da Carreira Assistência à Educação do Distrito Federal, em exercício na instituição educacional;

II - alunos com 16 (dezesseis) anos, ou acima, com freqüência regular na instituição educacional;

III - alunos legalmente capazes, nos termos do art. $5^{\circ}$ do Código Civil, com frequeência regular na instituição educacional;

IV - alunos com 16 (dezesseis) anos, ou acima, matriculados na Educação de Jovens e Adultos, na instituição educacional; $\mathrm{V}$ - pais ou responsáveis legais por alunos matriculados na instituição educacional.

$\S 1^{\circ}$ Servidores que atuam em mais de uma instituição educacional poderão exercer o direito de voto em todas elas.

$\S 2^{\circ}$ Os pais ou responsáveis que reúnam condições para participar do processo em mais de uma instituição educacional poderão exercer o direito de voto em todas elas.

$\S 3^{\circ} \mathrm{O}$ direito de voto poderá ser exercido somente uma vez em cada instituição educacional, independentemente de se pertencer a mais de uma categoria ou segmento.

Art. 16 - A equipe que obtiver o maior número de votos apurados em cada instituição educacional será a escolhida pela comunidade.

$\S 1^{\circ} \mathrm{Na}$ instituição educacional em que houver apenas uma equipe inscrita, ela será submetida à apreciação do Conselho Escolar e indicada caso obtenha metade mais um dos votos dos membros do Conselho.

$\S 2^{\circ}$ Em caso de empate, o Secretário de Estado de Educação do Distrito Federal submeterá à consideração do Governador do Distrito Federal a equipe que comprovar, pela ordem:

I - maior pontuação na avaliação do conhecimento de gestão escolar;

II - maior tempo de efetivo exercício na escola;

III - maior tempo de serviço no Magistério Público do Distrito Federal.

Art. 17 - Se não houver candidatos inscritos nem aprovados no processo seletivo, na forma estabelecida, o Secretário de Estado de Educação do Distrito Federal indicará servidores da Carreira Magistério Público do Distrito Federal que reúnam em seu perfil as características estabelecidas no art. $5^{\circ}$ desta Lei.

$\S 1^{\circ}$ Após a indicação, o Secretário de Estado de Educação submeterá os nomes ao Governador do Distrito Federal para nomeação aos cargos de diretor e de vice-diretor.

$\S 2^{\circ}$ Caso seja criada instituição educacional na rede pública de ensino no Distrito Federal, a indicação do diretor e do vice-diretor será nos termos do caput, até a realização de novo processo seletivo, nos termos desta Lei.

$\S 3^{\circ}$ Após nomeada, a equipe gestora terá o prazo de 60 (sessenta) dias para construir coletivamente a proposta pedagógica para a instituição educacional, para o ano de 2008, que deverá ser revista/atualizada a cada início de um novo ano letivo.

Art. 18 - No ato da posse, os servidores nomeados para os cargos de diretor e de vice-diretor assinarão Termo de Compromisso com a Secretaria de Estado de Educação do Distrito Federal, assumindo a gestão compartilhada da instituição educacional.

$\S 1^{\circ} \mathrm{O}$ Termo de Compromisso visa cumprir os objetivos constantes no art. $2^{\circ}$ desta Lei e conterá as competências da gestão compartilhada, administrativa, pedagógica e financeira, além daquelas decorrentes do cargo, bem como as atribuições a serem definidas pela Secretaria de Estado de Educação do Distrito Federal.

$\S 2^{\circ} \mathrm{A}$ comissão citada no art. 11 desta Lei divulgará, no ato de abertura da inscrição para o processo de escolha, o Termo de Compromisso, que conterá as cláusulas preestabelecidas a serem assumidas pela Secretaria de Estado de Educação e pela equipe nomeada.

$\S 3^{\circ}$ A Secretaria de Estado de Educação do Distrito Federal realizará, a cada 24 (vinte e quatro) meses, avaliação da gestão compartilhada da instituição educacional, respeitada a sua especificidade.

$\S 4^{\circ}$ Caso a avaliação da gestão compartilhada da instituição educacional atinja no mínimo $70 \%$ (setenta por cento) dos objetivos estabelecido no Termo de Compromisso, poderá a Secretaria de Estado de Educação do Distrito Federal reconduzir os servidores aos cargos de diretor e vice-diretor.

Art. 19 - O processo seletivo para indicação de candidatos aos cargos de diretor e de vice-diretor terá validade de 4 (quatro) anos, podendo a Secretaria de Estado de Educação prorrogar por igual período, caso haja interesse, observado o disposto no artigo $18, \S 3^{\circ}$.

Parágrafo único. A equipe classificada e não escolhida, nos termos da etapa III, ficará à disposição da Secretaria de Estado de Educação do Distrito Federal, constituindo banco de reserva.

Art. 20 - A Secretaria de Estado de Educação do Distrito Federal criará mecanismos próprios para acompanhamento anual do desempenho de cada instituição educacional, tendo como referência principal o Índice de Desempenho da Educação Básica - IDEB, divulgado pelo Ministério da Educação.

Parágrafo único. O acompanhamento anual de desempenho escolar de que trata o caput considerará o desempenho da instituição educacional em relação ao seu próprio desempenho no ano anterior.

Art. 21 - Caso haja exoneração de servidores nomeados para os cargos de diretor e de vice-diretor, a Secretaria de Estado de Educação do Distrito Federal poderá convocar, se houver, a equipe imediatamente mais bem classificada na instituição educacional, na etapa III.

Parágrafo único. Caso não haja outra equipe na instituição educacional para ser convocada, os cargos serão supridos na forma do artigo 17 .

Art. 22 - O Secretário de Estado de Educação do Distrito Federal proporá ao Governador a exoneração dos servidores nomeados para os cargos de diretor e de vice-diretor nos casos em que se comprove:

I - descumprimento do Termo de Compromisso;

II - pontuação inferior a 70 (setenta) pontos na avaliação da gestão compartilhada prevista no artigo $18, \S 3^{\circ}$, desta Lei; 
III - ato de irregularidade administrativa apurado em processo administrativo disciplinar, relacionado ao cargo que ocupa. Art. 23 - Caso haja vacância do cargo de diretor por interesse particular ou por razões não previstas no artigo 22 desta Lei, assumirá o vice-diretor.

Parágrafo único. No caso de inexistência ou impedimento do vice-diretor, assumirá a direção da instituição educacional servidor indicado na forma do artigo 17 desta Lei.

Art. 24 - Ficam criadas as Funções Gratificadas das instituições educacionais, FGIE-01 e FGIE-02, na forma do Anexo IV desta Lei.

$\S 1^{\circ}$ Caberá ao diretor a designação dos servidores, do Quadro de Pessoal do Governo do Distrito Federal, lotados na Secretaria de Estado de Educação do Distrito Federal, ocupantes do cargo da Carreira Magistério Público, para exercer a Função Gratificada de Supervisor Pedagógico, que perceberão as Funções Gratificadas de que trata o caput.

$\S 2^{\circ}$ Caberá ao diretor a designação dos servidores, do Quadro de Pessoal do Governo do Distrito Federal, lotados na Secretaria de Estado de Educação do Distrito Federal, ocupantes dos cargos da Carreira de Assistência à Educação, para exercer as Funções Gratificadas de Supervisor Administrativo e de Chefe de Secretaria da instituição educacional, que perceberão as Funções Gratificadas de que trata o caput.

$\S 3^{\circ}$ Poderá o diretor, excepcionalmente, designar servidores do Quadro de Pessoal do Governo do Distrito Federal, lotados na Secretaria de Estado de Educação do Distrito Federal, ocupantes do cargo da Carreira Magistério Público, para exercer a Função Gratificada de Supervisor Administrativo da instituição educacional.

Art. 25 - Os cargos comissionados de diretor e vice-diretor das instituições educacionais ficam alterados conforme os níveis constantes no Anexo IV desta Lei.

Art. 26 - Aos servidores ocupantes dos cargos de diretor, de vice-diretor e de supervisor pedagógico nas instituições educacionais, com exceção de servidor do Quadro de Pessoal Inativo do Distrito Federal, estende-se o benefício da Gratificação de Regência de Classe, criado pela Lei nº 202, de 9 de fevereiro de 1992.

Art. 27 - Para garantir a implementação da gestão compartilhada, a Secretaria de Estado de Educação do Distrito Federal regulamentará, em normas específicas, o processo de contratação temporária de professores para a rede pública de ensino do Distrito Federal e a descentralização de recursos necessários à administração das instituições educacionais.

$\S 1^{\circ}$ As contratações temporárias de que trata o caput serão efetuadas em valores de hora-aula, tendo como referência os padrões iniciais da remuneração da Carreira Magistério Público do Distrito Federal.

$\S 2^{\circ}$ Não se aplica, nas contratações de que trata o caput, o disposto nos artigos $5^{\circ}$ e $9^{\circ}$ da Lei $n^{\circ} 1.169$, de 24 de julho de 1996.

$\S 3^{\circ}$ As transferências automáticas de dotação orçamentária às instituições educacionais terão seus critérios publicados no Diário Oficial do Distrito Federal, no início do exercício financeiro, e as descentralizações financeiras serão divulgadas no sítio da Secretaria de Estado de Educação e em jornal de circulação local.

Art. 28 - Aplicam-se as disposições desta Lei a todas as instituições educacionais de ensino técnico-profissionalizante, escolas parques, escola da natureza e às demais instituições educacionais da rede pública de ensino do Distrito Federal. Art. 29 - Esta Lei entra em vigor na data de sua publicação.

Art. 30 - Revogam-se a Lei $n^{\circ} 3.086$, de 05 de dezembro de 2002, a Lei ${ }^{\circ} 3.454$, de 04 de outubro de 2004, a Lei $n^{\circ}$

3.355 , de 09 de junho de 2004 e as demais disposições em contrário.

Brasília, 25 de outubro de 2007.

$119^{\circ}$ da República e $48^{\circ}$ de Brasília

\section{JOSÉ ROBERTO ARRUDA}

ANEXO I - CONTEÚDO PROGRAMÁTICO

1. Gestão da Proposta Pedagógica.

2. Gestão da Educação e da Escola:

2.1 Currículo e Gestão Escolar:

2.1.1 Parâmetros Curriculares Nacionais.

2.1.2 Diretrizes Curriculares Nacionais da Educação Básica.

2.1.3 Referencial Curricular do Ensino Fundamental e Proposta Curricular do Ensino Médio do Distrito Federal.

2.1.4 Políticas e gestão da educação no Brasil e seus desafios atuais.

2.1.5 Regimento das escolas públicas do Distrito Federal.

3. Gestão do processo de ensino e aprendizagem e a utilização dos indicadores educacionais (IDEB, SAEB, Prova Brasil,

ENEM, PAS) e sociais na construção de ações de melhoria da aprendizagem:

3.1 Avaliação escolar e institucional.

4. Gestão de Recursos Humanos.

4.1 Aspectos legais da Organização e Administração Escolar.

5. Gestão de Recursos Públicos:

5.1 Patrimônio da escola.

5.2 Orientações básicas para a gestão escolar financeira

5.3 Manual de Gestão de Recursos Públicos por Associações.

5.4 Orientações para as Associações de apoio às Escolas.

6. Outros 
6.1 Lei n 9.394, de $^{2} 0$ de dezembro de 1996 (Lei de Diretrizes e Bases da Educação Nacional), em sua redação atual. 6.2 Lei n ${ }^{\circ} 8.112$, de 11 de dezembro de 1990 (Regime Jurídico Único do Servidor Público Civil), respeitado o art. $5^{\circ}$ da Lei $\mathrm{n}^{\circ} 197$, de 4 de dezembro de 1991

6.3 Lei no 8.069 , de 13 de julho de 1990 (Estatuto da Criança e do Adolescente).

6.4 Conselhos Escolares, Associações de Apoio e Grêmios Estudantis como elementos de liderança e fortalecimento da gestão administrativa, pedagógica e financeira da escola.

6.5 Programas educacionais da Secretaria de Estado de Educação do Distrito Federal (Educação Especial, Educação Continuada, Educação Inclusiva, Educação Ambiental, Orientação Educacional, entre outros).

ANEXO II-CRITERIOS PARA O JULGAMENTO DE TÍTULOS

\begin{tabular}{|c|c|}
\hline TITULOS & $\begin{array}{l}\text { MAXIMO } \\
\text { DE PONTOS }\end{array}$ \\
\hline $\begin{array}{l}\text { a) Tempo de serviço em docếacia, valendo } 1 \text { ponto para cada ano de exercicio a partir do } \\
\text { terceiro ano. }\end{array}$ & 5 \\
\hline $\begin{array}{l}\text { b) Expenência profissional no cargo de diretor e de vice-diretor, valendo } 2 \text { pontos para cada ano de } \\
\text { exercicio. }\end{array}$ & 10 \\
\hline $\begin{array}{l}\text { c) Experiência profíssional no cargo de assistente, em coordenaçâo pedagógica e em atividade de } \\
\text { orientação educacional, valendo } 1 \text { ponto para cada ano de exercicio. }\end{array}$ & 5 \\
\hline d) Curso de Doutorado em áren educacional. & 5 \\
\hline e) Curso de Mestrado em área echucacional. & 5 \\
\hline f) Curso de Especialização em área educacional, com carga mínima de 360 horas. & 5 \\
\hline $\begin{array}{l}\text { g) Curso de Pós-Graduação, en nivel de especialização, com carga minima de } 360 \text { horas, em área de } \\
\text { Gestắo. }\end{array}$ & 5 \\
\hline $\begin{array}{l}\text { h) Cursos na área de Gestâo Escolar ou simular, com carga mínima de } 180 \text { horas, valendo } 2 \text { pontos } \\
\text { para cada um. }\end{array}$ & 6 \\
\hline $\begin{array}{l}\text { 1) Livros ou artigos científicos publicados, nos últimos } 5 \text { (circo) anos, em revistas de circulação } \\
\text { nacional que tenham correlaçẫo com a Educação, valendo } 1 \text { ponto para cada um. }\end{array}$ & 2 \\
\hline 1) Realização de trabalho voluntário, devidamente comprovado. & 2 \\
\hline TOTAL DE PONTOS & 50 \\
\hline
\end{tabular}

\section{ANEXO III — PLANO DE TRABALHO DA GESTÃO ESCOLAR*.}

I. Elaborando o Plano de Trabalho da Gestão Escolar:

1. Identificação: nome do candidato, cargo, matrícula funcional, nome da instituição educacional, endereço, níveis de ensino e localização (urbana ou rural).

2. Introdução/Apresentação: demonstrar poder de síntese ao apresentar o Plano de Trabalho da Gestão Escolar.

3. Justificativa: apresentar, resumidamente, os resultados e diagnóstico da avaliação institucional e ressaltar as razões pelas quais se apresenta o Plano de Trabalho da Gestão Escolar, por que acredita nele e qual a sua relevância e benefícios à comunidade escolar.

4. Objetivos: apresentar as pretensões de melhoria para a instituição educacional e as possibilidades de concretização.

5. Metas: expor as ações a curto e médio prazos, focadas nos objetivos pretendidos.

6. Estratégias: propor um conjunto de atividades que dêem sustentação às metas.

7. Avaliação: propor um processo avaliativo que seja coerente com as metas e as estratégias a serem adotadas. 
8. Cronograma: apresentar uma previsão de como desenvolver o Plano de Trabalho da Gestão Escolar.

9. Referências Bibliográficas: citar autores e obras em que se fundamentou o Plano de Trabalho da Gestão Escolar.

*Observação:

1) Deverão ser entregues 2 (duas) cópias do Plano de Trabalho da Gestão Escolar por equipe concorrente, constando a identificação dos componentes.

2) O Plano de Trabalho da Gestão Escolar deverá conter, no mínimo, doze laudas digitadas em fonte arial tamanho 12 ou times new roman tamanho 13; espacejamento $1,5 \mathrm{~cm}$ para o corpo do trabalho e simples para as citações e notas de rodapé; alinhamento justificado à esquerda e à direita; margem superior $3 \mathrm{~cm}$, inferior $2 \mathrm{~cm}$, esquerda $3 \mathrm{~cm}$ e direita $2 \mathrm{~cm}$; cabeçalho $1,5 \mathrm{~cm}$ e rodapé

$1,25 \mathrm{~cm}$; parágrafo $1,5 \mathrm{~cm}$ a partir da margem. Escolhida a fonte, utilizar a mesma em todo o trabalho. A formatação e a impressão devem ser feitas em folha branca, formato A4

\begin{tabular}{|c|c|c|c|c|c|c|c|c|}
\hline \multirow{3}{*}{$\begin{array}{c}\text { Instituiçào educacional } \\
\text { IE }\end{array}$} & \multirow{3}{*}{$\begin{array}{l}\text { Qtd. } \\
\text { I.E. }\end{array}$} & \multicolumn{2}{|c|}{$\begin{array}{l}\text { Cargos Comissionados } \\
\text { DFIE }\end{array}$} & \multicolumn{5}{|c|}{$\begin{array}{l}\text { Funçōes Gratificadas } \\
\text { FGIE }\end{array}$} \\
\hline & & \multirow[b]{2}{*}{ Diretor } & \multirow[t]{2}{*}{ Vice-Diretor } & \multirow[t]{2}{*}{ Chefe de Secretaria } & \multicolumn{2}{|c|}{ Supervisor Administrativo } & \multicolumn{2}{|c|}{ Supervisor Pedagógico } \\
\hline & & & & & notumo & diumo & noturno & diurno \\
\hline $\begin{array}{l}\text { CENIRO DE ATENCAO INIEGRADA A CRIANCCA E AO } \\
\text { ADOLESCENTE - CAIC }\end{array}$ & 14 & DFIE -10 & DFIE- 08 & FGIE- 01 & FGIE-02 & FGIE-01 & FGIE-02 & FGIE-01 \\
\hline JARDIM DE INFÂNCIA - II & 28 & DFIE-07 & DFIE- 06 & FGIE- 01 & FGIE-02 & FGIE-01 & FGIE-02 & FGIE-01 \\
\hline CENTRO DE EDUCACCÃO INFANTIL - CEI & 15 & DFIE -07 & DFIE- 06 & FGIE- 01 & FGIE-02 & FGIE-01 & FGIE.02 & FGIE-01 \\
\hline ESCOLA CLASSE-EC & 316 & DFIE- 07 & DFIE- 06 & FGIE- 01 & FGIE-02 & FGIE-01 & FGIE-02 & FGIE-01 \\
\hline CENTRO DE ENSINO FUNDAMENTAL - CEF & 147 & DFIE-10 & DFIE- 08 & FGIE- 01 & FGIE-02 & FGIE-01 & FGIE-02 & FGIE-01 \\
\hline CENTRO EDUCACIONAL - CED & 31 & DFIE -10 & DFIE- 08 & FGIE- 01 & FGIE-02 & FGIE-01 & FGIE-02 & FGIE-01 \\
\hline CENTRO DE ENSINO MÉDIO - CEM & 31 & DFIE-10 & DFIE- 08 & FGIE-01 & FGIE-02 & FGIE-01 & FGIE-02 & FGIE-01 \\
\hline CENTRO DE ENSINO SUPLETIVO - CES & 2 & DFIE-10 & DFIE- 08 & FGIE- 01 & FGIE- 02 & FGIE-01 & FGIE-02 & FGIE-01 \\
\hline $\begin{array}{l}\text { CENTRO DE ENSDNO MEDIO NTEGRADO A EDUCAÇAO } \\
\text { PROFISSIONAL - CEMIN }\end{array}$ & 1 & DFIE- 10 & DFIE- 08 & FGIE- 01 & FGIE-02 & FGIE-01 & FGIE-02 & FGIE-01 \\
\hline CENTRO DE EDUCAÇÃO ESPECIAL - CEE & 12 & DFIE -10 & DFIE- 08 & FGIE- 01 & FGIE-02 & FGIE-01 & FGIE-02 & FGIE-01 \\
\hline CENTRO INTEGRADO DE EDUCAÇÃO ESPECIAL - CIEE & 1 & DFIE- 10 & DFIE- 08 & FGIE- 01 & FGIE-02 & FGIE-01 & FGIE-02 & FGIE-01 \\
\hline CENTRO INTEGRADO DE EDUCAÇÃO FISICA - CIEF & 1 & DFIE- 10 & DFIE- 08 & FGIE- 01 & FGIE-02 & FGIE-01 & FGIE-02 & FGIE-01 \\
\hline CENTRO INTERESCOLAR DE LINGUAS - CIL & 8 & DFIE -10 & DFIE- 08 & FGIE- 01 & FGIE-02 & FGIE-01 & FGIE-02 & FGIE-01 \\
\hline ESCOLA PARQUE & 5 & DFIE- 10 & DFIE- 08 & FGIE- 01 & FGIE-02 & FGIE-01 & FGIE-02 & FGIE-01 \\
\hline ESCOLA MENINOS E MENINAS DO PARQUE & 1 & DFIE -10 & DFIE- 08 & FGIE-01 & FGIE-02 & FGIE-01 & FGIE-02 & FGIE-01 \\
\hline PROEM & 1 & DFIE- 10 & DFIE- 08 & FGIE- 01 & FGIE-02 & FGIE-01 & FGIE-02 & FGIE-01 \\
\hline ESCOLA DA NATUREZA & 1 & DFIE -07 & DFIE- 06 & FGIE- 01 & FGIE-02 & FGIE-01 & FGIE-02 & FGIE-01 \\
\hline $\begin{array}{l}\text { CENIRO DE EDUCACCAO PROFISSIONAL - ESCOLA DE } \\
\text { MUSICA DE BRASILIA. }\end{array}$ & 1 & DFIE-10 & DFIE- 08 & FGIE- 01 & FGIE-02 & FGIE-01 & FGIE-02 & FGIE-01 \\
\hline R\$1.218,15 (um mil, duzentos e dezoito reais e & & & & & & & & \\
\hline $\mathrm{R} \$ 948,33$ (novecentos e quarenta e oito reais e trinta e & atavos) & & & & & & & \\
\hline $\mathrm{R} \$ 813,65$ (oitocentos e treze reais e sessenta e cinco ce & & & & & & & & \\
\hline R\$679,06 (seiscentos e setenta e nove reais e seis centa & & & & & & & & \\
\hline RS620,00 (seiscentos e vinte reais) & & & & & & & & \\
\hline R\$325,00 (trezentos e vinte e cinco reais) & & & & & & & & \\
\hline
\end{tabular}


LEI N 4.751, DE 07 DE FEVEREIRO DE 2012.

(Autoria do Projeto: Poder Executivo)

Dispõe sobre o Sistema de Ensino e a Gestão Democrática do Sistema de Ensino Público do Distrito Federal. O GOVERNADOR DO DISTRITO FEDERAL, FAÇO SABER QUE A CÂMARA LEGISLATIVA DO DISTRITO FEDERAL DECRETA E EU SANCIONO A SEGUINTE LEI:

Art. $1^{\circ}$ Esta Lei trata do Sistema de Ensino e da gestão democrática da Rede Pública de Ensino do Distrito Federal, conforme disposto no art. 206, VI, da Constituição Federal, no art. 222 da Lei Orgânica do Distrito Federal e nos arts. $3^{\circ}$ e 14 da Lei no 9.394, de 20 de dezembro de 1996.

CAPÍTULO I

DAS FINALIDADES E DOS PRINCÍPIOS DA GESTÃO DEMOCRÁTICA

Art. $2^{\circ} \mathrm{A}$ gestão democrática da Rede Pública de Ensino do Distrito Federal, cuja finalidade é garantir a centralidade da escola no sistema e seu caráter público quanto ao financiamento, à gestão e à destinação, observará os seguintes princípios:

I - participação da comunidade escolar na definição e na implementação de decisões pedagógicas, administrativas e financeiras, por meio de órgãos colegiados, e na eleição de diretor e vice-diretor da unidade escolar;

II - respeito à pluralidade, à diversidade, ao caráter laico da escola pública e aos direitos humanos em todas as instâncias da Rede Pública de Ensino do Distrito Federal;

III - autonomia das unidades escolares, nos termos da legislação, nos aspectos pedagógicos, administrativos e de gestão financeira;

IV - transparência da gestão da Rede Pública de Ensino, em todos os seus níveis, nos aspectos pedagógicos, administrativos e financeiros;

$\mathrm{V}$ - garantia de qualidade social, traduzida pela busca constante do pleno desenvolvimento da pessoa, do preparo para o exercício da cidadania e da qualificação para o trabalho;

VI - democratização das relações pedagógicas e de trabalho e criação de ambiente seguro e propício ao aprendizado e à construção do conhecimento;

VII - valorização do profissional da educação.

\section{CAPÍTULO II}

DA COMUNIDADE ESCOLAR

Art. $3^{\circ}$ Para os efeitos desta Lei, especialmente no que tange à habilitação como eleitores, entendem-se por comunidade escolar das escolas públicas, conforme sua tipologia:

I - estudantes matriculados em instituição educacional da rede pública, com idade mínima de treze anos e frequência superior a cinquenta por cento das aulas no bimestre anterior;

II - estudantes matriculados em escolas técnicas e profissionais em cursos de duração não inferior a seis meses e com carga horária mínima de 180 horas, com frequência superior a cinquenta por cento das aulas no bimestre anterior;

III - estudantes matriculados na educação de jovens e adultos com frequência superior a cinquenta por cento das aulas no bimestre anterior;

IV - estudantes matriculados em cursos semestrais, com idade mínima de treze anos e frequência superior a cinquenta por cento das aulas no semestre em curso;

V - mães, pais ou responsáveis por estudantes da Rede Pública de Ensino, os quais terão direito a um voto por escola em que estejam habilitados para votar;

VI - integrantes efetivos da carreira Magistério Público do Distrito Federal em exercício na unidade escolar ou nela concorrendo a um cargo; VII - integrantes efetivos da carreira Assistência à Educação, em exercício na unidade escolar ou nela concorrendo a um cargo;

VIII - professores contratados temporariamente pela Secretaria de Estado de Educação do Distrito Federal - SEDF em exercício na unidade escolar por período não inferior a dois bimestres;

Parágrafo único. Os grupos integrantes da comunidade escolar discriminados neste artigo organizam-se em dois conjuntos compostos, respectivamente, por aqueles descritos nos incisos de I a $\mathrm{V}$ e aqueles constantes nos incisos de VI a VIII.

CAPÍTULO III

DA AUTONOMIA DA ESCOLA PÚBLICA

Seção I

Da Autonomia Pedagógica

Art. $4^{\circ}$ Cada unidade escolar formulará e implementará seu projeto político-pedagógico, em consonância com as políticas educacionais vigentes e as normas e diretrizes da Rede Pública de Ensino do Distrito Federal.

Parágrafo único. Cabe à unidade escolar, considerada a sua identidade e de sua comunidade escolar, articular o projeto político-pedagógico com os planos nacional e distrital de educação.

Seção II

Da Autonomia Administrativa

Art. $5^{\circ} \mathrm{A}$ autonomia administrativa das instituições educacionais, observada a legislação vigente, será garantida por:

I - formulação, aprovação e implementação do plano de gestão da unidade escolar;

II - gerenciamento dos recursos oriundos da descentralização financeira;

III - reorganização do seu calendário escolar nos casos de reposição de aulas.

Seção III

Da Autonomia Financeira

Art. $6^{\circ} \mathrm{A}$ autonomia da gestão financeira das unidades escolares de ensino público do Distrito Federal será assegurada pela administração dos recursos pela respectiva unidade executora, nos termos de seu projeto político-pedagógico, do plano de gestão e da disponibilidade financeira nela alocada, conforme legislação vigente.

$\S 1^{\circ}$ Entende-se por unidade executora a pessoa jurídica de direito privado, de fins não econômicos, que tenha por finalidade apoiar as unidades escolares ou diretorias regionais de ensino no cumprimento de suas respectivas competências e atribuições

$\S 2^{\circ}$ Para recebimento dos recursos de que tratam o caput e o art. $7^{\circ}$, a presidência ou função equivalente da unidade executora deverá ser exercida pelo diretor da unidade escolar ou da diretoria regional de ensino apoiada.

Art. $7^{\circ}$ Constituem recursos das unidades executoras das unidades escolares os repasses e descentralizações de recursos financeiros, as doações e subvenções que thes forem concedidas pela União, pelo Distrito Federal, por pessoas físicas e jurídicas, entidades públicas, associações de classe e entes comunitários.

Parágrafo único. Serão garantidos e criados, no prazo máximo de noventa dias, mecanismos de fortalecimento de controle social sobre a destinação e a aplicação de recursos públicos e sobre ações do governo na educação.

Art. $8^{\circ}$ Para garantir a implementação da gestão democrática, a SEDF regulamentará, em normas específicas, a descentralização de recursos necessários à administração das unidades escolares. 
Parágrafo único. As transferências de recursos financeiros às unidades escolares e diretorias regionais de ensino, por meio de suas respectivas unidades executoras, terão seus critérios e valores publicados por meio do sítio da SEDF na internet, pelo Diário Oficial do Distrito Federal e por jornal de circulação local.

\section{CAPÍTULO IV \\ DA GESTÃO DEMOCRÁTICA Seção I}

Das Disposições Iniciais

Art. $9^{\circ}$ A Gestão Democrática será efetivada por intermédio dos seguintes mecanismos de participação, a ser regulamentados pelo Poder Executivo:

I - órgãos colegiados:

a) Conferência Distrital de Educação

b) Fórum Distrital de Educação;

c) Conselho de Educação do Distrito Federal;

d) Assembleia Geral Escolar;

e) Conselho Escolar;

f) Conselho de Classe;

g) grêmio estudantil;

II - direção da unidade escolar.

Seção II

Dos Órgãos Colegiados

Subseção I

Da Conferência Distrital de Educação

Art. 10. A Conferência Distrital de Educação constitui-se em espaço de debate, mobilização, pactuação e formulação das políticas de educação, com vistas aos seguintes objetivos:

I - propor políticas educacionais de forma articulada;

II - institucionalizar política de gestão participativa, democrática e descentralizada;

III - propor políticas educacionais que garantam a qualidade social da educação, o acesso e a permanência na escola, a progressão e a conclusão dos estudos com sucesso;

IV - estruturar políticas educacionais que fomentem o desenvolvimento social sustentável, a diversidade cultural e a inclusão social;

V - implementar política de valorização dos profissionais da educação.

Parágrafo único. Da Conferência Distrital de Educação participarão estudantes, pais de alunos, agentes públicos e representantes de entidades da sociedade civil.

Art. 11. A Conferência Distrital de Educação debaterá o projeto do Plano Decenal de Educação do Distrito Federal, a ser encaminhado para apreciação pelo Poder Legislativo, nos termos do Plano Nacional de Educação, com a finalidade de definir objetivos, diretrizes e metas para a educação no Distrito Federal.

Parágrafo único. A Conferência Distrital de Educação, que precederá a Conferência Nacional de Educação, será organizada por comissão instituída especificamente para este fim, pela SEDF, a qual contará com a participação de agentes públicos e entidades da sociedade civil e terá sua programação, temário e metodologia definidos em regimento interno.

Subseção II

Do Fórum Distrital de Educação

Art. 12. O Fórum Distrital de Educação, de caráter permanente, nos moldes do Fórum Nacional de Educação, tem a finalidade de acompanhar e avaliar a implementação das políticas públicas de educação no âmbito do Distrito Federal.

Art. 13. A SEDF coordenará as atividades do Fórum Distrital de Educação e garantirá os recursos necessários para realização de seus trabalhos. Subseção III

Do Conselho de Educação do Distrito Federal

Art. 14. O Conselho de Educação do Distrito Federal é órgão consultivo-normativo de deliberação coletiva e de assessoramento superior à SEDF, com a atribuição de definir normas e diretrizes para o Sistema de Ensino do Distrito Federal, bem como de orientar, fiscalizar e acompanhar o ensino das redes pública e privada do Sistema de Ensino do Distrito Federal.

Art. 15. O Conselho de Educação do Distrito Federal disporá sobre sua organização e funcionamento em regimento interno a ser aprovado pelo Poder Executivo.

Art. 16. O Conselho de Educação do Distrito Federal, composto por pessoas de notório saber e probidade, com ampla experiência em matéria de educação, será constituído por dezesseis conselheiros designados pelo Governador do Distrito Federal, observada a necessária representação dos níveis de ensino e a participação de representantes dos sistemas de ensino público e privado, sendo:

I - oito representantes da SEDF, dos quais quatro serão indicados pelo Secretário de Estado de Educação e quatro serão natos, conforme disposto a seguir:

a) titular da subsecretaria ou unidade equivalente responsável pela formulação das diretrizes pedagógicas para a implementação de políticas públicas da educação básica;

b) titular da subsecretaria ou unidade equivalente responsável pela formulação das diretrizes para o planejamento do Sistema de Ensino do Distrito Federal e a implementação da avaliação educacional desse Sistema;

c) titular da subsecretaria ou unidade equivalente responsável pela formação continuada dos profissionais de educação;

d) titular da unidade responsável pela inspeção, pelo acompanhamento e pelo controle da aplicação da legislação educacional específica do Sistema de Ensino do Distrito Federal;

II - oito representantes da comunidade acadêmica e escolar e de entidades representativas dos profissionais da educação, indicados pelas respectivas instituições, observado o disposto a seguir:

a) um representante de instituição pública federal de ensino superior

b) um representante de instituição pública federal de educação tecnológica;

c) um representante de entidade sindical representativa dos servidores da carreira Magistério Público do Distrito Federal;

d) um representante de entidade sindical representativa dos servidores da carreira Assistência à Educação Pública do Distrito Federal;

e) um representante de entidade sindical representativa dos professores em estabelecimentos particulares de ensino do Distrito Federal;

f) um representante de entidade sindical representativa das escolas particulares do Distrito Federal;

g) um representante de entidade representativa dos estudantes secundaristas do Distrito Federal;

h) um representante de entidade sindical representativa das instituições privadas de educação superior.

Art. 17. Os conselheiros terão mandato de quatro anos, permitida uma única recondução consecutiva, por igual período, excetuando-se os membros natos, cujo mandato terá duração igual ao período de investidura no cargo executivo.

$\S 1^{\circ}$ Haverá renovação de metade do Conselho a cada dois anos.

$\S 2^{\circ}$ Em caso de vacância, será nomeado novo conselheiro para completar o período restante do mandato. 
$\S 3^{\circ} \mathrm{O}$ mandato do conselheiro escolar será considerado extinto em caso de renúncia expressa ou tácita, configurada esta última pelo não comparecimento a seis reuniões no período de doze meses.

Art. 18. O Conselho de Educação do Distrito Federal será presidido por um de seus membros, eleito por seus pares para mandato de dois anos, sem possibilidade de reeleição para o período subsequente.

Art. 19. As deliberações do Conselho serão tomadas pela maioria simples dos votos, presente a maioria dos conselheiros empossados e em exercício, salvo nos casos em que o regimento interno do Conselho de Educação do Distrito Federal exija quórum superior.

Art. 20. O Conselho de Educação se reunirá, ordinariamente, uma vez por semana e, extraordinariamente, quando necessário, por convocação:

I- de seu presidente;

II- do Secretário de Educação;

III - da maioria absoluta de seus membros.

\section{Subseção IV}

Da Assembleia Geral Escolar

Art. 21. A Assembleia Geral Escolar, instância máxima de participação direta da comunidade escolar, abrange todos os segmentos escolares e é responsável por acompanhar o desenvolvimento das ações da escola.

Art. 22. A Assembleia Geral Escolar se reunirá ordinariamente a cada seis meses, ou extraordinariamente, sempre que a comunidade escolar indicar a necessidade de ampla consulta sobre temas relevantes, mediante convocação:

I - de integrantes da comunidade escolar, na proporção de dez por cento da composição de cada segmento;

II - do Conselho Escolar;

III - do diretor da unidade escolar.

$\S 1^{\circ} \mathrm{O}$ edital de convocação da Assembleia Geral Escolar será elaborado e divulgado amplamente pelo Conselho Escolar, com antecedência mínima de três dias úteis no caso das reuniões extraordinárias e de quinze dias no caso das ordinárias.

$\S 2^{\circ}$ As normas gerais de funcionamento da Assembleia Geral Escolar, inclusive o quórum de abertura dos trabalhos e o de deliberação, serão estabelecidas pela SEDF.

$\S 3^{\circ} \mathrm{Na}$ ausência de Conselho Escolar constituído, as competências previstas no $\S 1^{\circ}$ recairão sobre a direção da unidade escolar.

Art. 23. Compete à Assembleia Geral Escolar:

I - conhecer do balanço financeiro e do relatório findo e deliberar sobre eles;

II - avaliar semestralmente os resultados alcançados pela unidade escolar;

III - discutir e aprovar, motivadamente, a proposta de exoneração de diretor ou vice-diretor das unidades escolares, obedecidas as competências e a legislação vigente;

IV - apreciar o regimento interno da unidade escolar e deliberar sobre ele, em assembleia especificamente convocada para este fim, conforme legislação vigente;

$\mathrm{V}$ - aprovar ou reprovar a prestação de contas dos recursos repassados à unidade escolar, previamente ao encaminhamento devido aos órgãos de controle;

VI - resolver, em grau de recurso, as decisões das demais instâncias deliberativas da unidade escolar;

VII - convocar o presidente do Conselho Escolar e a equipe gestora, quando se fizer necessário;

VIII - decidir sobre outras questões a ela remetidas.

Parágrafo único. As decisões e os resultados da Assembleia Geral Escolar serão registrados em ata e os encaminhamentos decorrentes serão efetivados pelo Conselho Escolar, salvo disposição em contrário.

Subseção V

Do Conselho Escolar

Art. 24. Em cada instituição pública de ensino do Distrito Federal, funcionará um Conselho Escolar, órgão de natureza consultiva, fiscalizadora, mobilizadora, deliberativa e representativa da comunidade escolar, regulamentado pela SEDF.

Parágrafo único. O Conselho Escolar será composto por, no mínimo, cinco e, no máximo, vinte e um conselheiros, conforme a quantidade de estudantes da unidade escolar, de acordo com o Anexo Único desta Lei.

Art. 25. Compete ao Conselho Escolar, além de outras atribuições a serem definidas pelo Conselho de Educação do Distrito Federal:

I - elaborar seu regimento interno;

II - analisar, modificar e aprovar o plano administrativo anual elaborado pela direção da unidade escolar sobre a programação e a aplicação dos recursos necessários à manutenção e à conservação da escola;

III - garantir mecanismos de participação efetiva e democrática da comunidade escolar na elaboração do projeto político-pedagógico da unidade escolar;

IV - divulgar, periódica e sistematicamente, informações referentes ao uso dos recursos financeiros, à qualidade dos serviços prestados e aos resultados obtidos;

V - atuar como instância recursal das decisões do Conselho de Classe, nos recursos interpostos por estudantes, pais ou representantes legalmente constituídos e por profissionais da educação;

VI - estabelecer normas de funcionamento da Assembleia Geral e convocá-la nos termos desta Lei;

VII - estruturar o calendário escolar, no que competir à unidade escolar, observada a legislação vigente;

VIII - fiscalizar a gestão da unidade escolar;

IX - promover, anualmente, a avaliação da unidade escolar nos aspectos técnicos, administrativos e pedagógicos;

$\mathrm{X}$ - analisar e avaliar projetos elaborados ou em execução por quaisquer dos segmentos que compõem a comunidade escolar;

XI - intermediar conflitos de natureza administrativa ou pedagógica, esgotadas as possibilidades de solução pela equipe escolar;

XII - propor mecanismos para a efetiva inclusão, no ensino regular, de alunos com deficiência;

XIII - debater indicadores escolares de rendimento, evasão e repetência e propor estratégias que assegurem aprendizagem significativa para todos.

$\S 1^{\circ}$ Em relação aos aspectos pedagógicos, serão observados os princípios e as disposições constitucionais, os pareceres e as resoluções dos órgãos normativos federal e distrital e a legislação do Sistema de Ensino do Distrito Federal.

$\S 2^{\circ}$ Quando se tratar de deliberação que exija responsabilidade civil ou criminal, os estudantes no exercício da função de conselheiro escolar serão representados, no caso dos menores de dezesseis anos, ou assistidos, em se tratando de menores de dezoito anos e maiores de dezesseis anos, por seus pais ou responsáveis, devendo comparecer às reuniões tanto os representados ou assistidos como os representantes ou assistentes. Art. 26. Os membros do Conselho Escolar serão eleitos por todos os membros da comunidade escolar habilitados conforme o art. $3^{\circ}$, em voto direto, secreto e facultativo, uninominalmente, observado o disposto nesta Lei.

$\S 1^{\circ}$ As eleições para representantes dos segmentos da comunidade escolar para integrar o Conselho Escolar se realizarão ao final do primeiro bimestre letivo, sendo organizadas e coordenadas pelas comissões central e local referidas no art. 48.

$\S 2^{\circ}$ Poderão se candidatar à função de conselheiro escolar os membros da comunidade escolar relacionados no art. $3^{\circ}$, I a VII.

Art. 27. O Diretor da unidade escolar integrará o Conselho Escolar como membro nato.

Parágrafo único. Nas ausências e impedimentos no Conselho Escolar, o diretor será substituído pelo vice-diretor ou, não sendo isto possível, por outro membro da equipe gestora. 
Art. 28. O mandato de conselheiro escolar será de três anos, permitida uma reeleição consecutiva.

Art. 29. O exercício do mandato de conselheiro escolar será considerado serviço público relevante e não será remunerado.

Art. 30. O Conselho Escolar elegerá, dentre seus membros, presidente, vice-presidente e secretário, os quais cumprirão tarefas específicas definidas no regimento interno do colegiado, não podendo a escolha para nenhuma dessas funções recair sobre membros da equipe gestora da unidade escolar.

Parágrafo único. Compete ao presidente do Conselho Escolar dirigir a Assembleia Geral Escolar.

Art. 31. O Conselho Escolar se reunirá, ordinariamente, uma vez por mês e, extraordinariamente, a qualquer tempo, por convocação:

I- do presidente;

II - do diretor da unidade escolar;

III - da maioria de seus membros.

$\S 1^{\circ}$ Para instalação das reuniões do Conselho Escolar, será exigida a presença da maioria de seus membros.

$\S 2^{\circ}$ As reuniões do Conselho Escolar serão convocadas com antecedência mínima de quarenta e oito horas.

$\S 3^{\circ}$ As reuniões do Conselho Escolar serão abertas, com direito a voz, mas não a voto, a todos os que trabalham, estudam ou têm filho matriculado na unidade escolar, a profissionais que prestam atendimento à escola, a membros da comunidade local, a movimentos populares organizados, a entidades sindicais e ao grêmio estudantil.

Art. 32. A vacância da função de conselheiro se dará por renúncia, aposentadoria, falecimento, desligamento da unidade de ensino, alteração na composição da equipe gestora ou destituição, sendo a função vacante assumida pelo candidato com votação imediatamente inferior à daquele eleito com menor votação no respectivo segmento.

$\S 1^{\circ} \mathrm{O}$ não comparecimento injustificado de qualquer conselheiro a três reuniões ordinárias consecutivas ou a cinco alternadas implicará vacância da função.

$\S 2^{\circ}$ Ocorrerá destituição de conselheiro por deliberação da Assembleia Geral Escolar, em decisão motivada, garantindo-se a ampla defesa e o contraditório.

$\S 3^{\circ}$ As hipóteses previstas nos $\S \S 1^{\circ}$ e $2^{\circ}$ não se aplicam aos conselheiros natos.

Art. 33. Caso a instituição escolar não conte com estudantes que preencham a condição de elegibilidade, as respectivas vagas no Conselho serão destinadas ao segmento dos pais e mães de alunos.

Parágrafo único. A comunidade escolar das unidades que atendem estudantes com deficiência envidará todos os esforços para assegurar-lhes a participação, e de seus pais ou responsáveis, como candidatos ao Conselho Escolar.

Art. 34. Os profissionais de educação investidos em cargos de conselheiros escolares, em conformidade com as normas de remanejamento e distribuição de carga horária e ressalvados os casos de decisão judicial transitada em julgado ou após processo administrativo disciplinar na forma da legislação vigente, terão assegurada a sua permanência na unidade escolar pelo período correspondente ao exercício do mandato e um ano após seu término.

\section{Subseção VI}

Do Conselho de Classe

Art. 35. O Conselho de Classe é órgão colegiado integrante da gestão democrática e se destina a acompanhar e avaliar o processo de educação, de ensino e de aprendizagem, havendo tantos conselhos de classe quantas forem as turmas existentes na escola.

$\S 1^{\circ} \mathrm{O}$ Conselho de Classe será composto por:

I - todos os docentes de cada turma e representante da equipe gestora, na condição de conselheiros natos;

II - representante dos especialistas em educação;

III - representante da carreira Assistência à Educação;

IV - representante dos pais ou responsáveis;

$\mathrm{V}$ - representante dos alunos a partir do $6^{\circ}$ ano ou primeiro segmento da educação de jovens e adultos, escolhidos por seus pares, garantida a representatividade dos alunos de cada uma das turmas;

VI - representantes dos serviços de apoio especializado, em caso de turmas inclusivas.

$\S 2^{\circ} \mathrm{O}$ Conselho de Classe se reunirá, ordinariamente, uma vez a cada bimestre e, extraordinariamente, a qualquer tempo, por solicitação do diretor da unidade escolar ou de um terço dos membros desse colegiado.

$\S 3^{\circ}$ Cada unidade escolar elaborará as normas de funcionamento do Conselho de Classe em conformidade com as diretrizes da SEDF. Subseção VII

Dos Grêmios Estudantis

Art. 36. As instituições educacionais devem estimular e favorecer a implementação e o fortalecimento de grêmios estudantis, como forma de desenvolvimento da cidadania e da autonomia dos estudantes e como espaço de participação estudantil na gestão escolar.

Parágrafo único. A organização e o funcionamento do grêmio escolar serão estabelecidos em estatuto, a ser aprovado pelo segmento dos estudantes da respectiva unidade escolar.

\section{CAPÍTULO V}

\section{DA DIREÇÃO ELEITA PELA COMUNIDADE ESCOLAR}

Art. 37. A direção das instituições educacionais será desempenhada pela equipe gestora composta por diretor e vice-diretor, supervisores e chefe de secretaria, conforme a modulação de cada escola, em consonância com as deliberações do Conselho Escolar, respeitadas as disposições legais.

Art. 38. A escolha do diretor e do vice-diretor será feita mediante eleição, por voto direto e secreto, vedado o voto por representação, sendo vitoriosa a chapa que alcançar a maior votação, observado o disposto no art. 51.

Parágrafo único. O processo eleitoral obedecerá às seguintes etapas:

I - inscrição das chapas e divulgação dos respectivos Planos de Trabalho para Gestão da Escola junto à comunidade escolar;

II - eleição, pela comunidade escolar;

III - nomeação pelo Governador do Distrito Federal;

IV - participação dos eleitos em curso de gestão escolar oferecido pela SEDF, visando à qualificação para o exercício da função, exigida frequência mínima de setenta e cinco por cento.

Art. 39. O plano de trabalho de que trata o art. 38, parágrafo único, I, é condição indispensável à habilitação dos candidatos às eleições de diretor e vice-diretor e será defendido pelas chapas, perante a comunidade escolar, em sessão pública convocada pela Comissão Eleitoral Local. Parágrafo único. O Plano de Trabalho para a Gestão da Escola deve explicitar os aspectos pedagógicos, administrativos e financeiros prioritários para a gestão dos candidatos e destacar os objetivos e as metas para melhoria da qualidade da educação, bem como as estratégias para preservação do patrimônio público e para a participação da comunidade no cotidiano escolar, na gestão dos recursos financeiros e no acompanhamento e na avaliação das ações pedagógicas.

Art. 40. Poderá concorrer aos cargos de diretor ou de vice-diretor o servidor ativo da carreira Magistério Público do Distrito Federal ou da Carreira Assistência à Educação Pública do Distrito Federal que comprove:

I - ter experiência no sistema de educação pública do Distrito Federal, como servidor efetivo, há, no mínimo, três anos e estar em exercício em unidade escolar vinculada à Diretoria Regional de Ensino na qual concorrerá;

II - no caso de professor, ter, no mínimo, três anos de exercício; 
III - no caso de especialista em educação, ter, no mínimo, três anos de exercício em unidade escolar na condição de servidor efetivo;

IV - no caso de profissional da carreira Assistência à Educação, ter, no mínimo, três anos de exercício em unidade escolar na condição de servidor efetivo;

$\mathrm{V}$ - ter disponibilidade para o cumprimento do regime de quarenta horas semanais, com dedicação exclusiva para o exercício do cargo a que concorre;

VI - ser portador de diploma de curso superior ou formação tecnológica em áreas afins às carreiras Assistência à Educação ou Magistério Público do Distrito Federal;

VII - ter assumido o compromisso de, após a investidura no cargo de diretor ou vice-diretor, frequentar o curso de gestão escolar de que trata o art. 60 .

$\S 1^{\circ}$ A candidatura a cargo de diretor ou de vice-diretor fica restrita, em cada eleição, a uma única unidade escolar da Rede Pública de Ensino do Distrito Federal, na qual o servidor esteja atuando ou já tenha atuado.

$\S 2^{\circ}$ Ao menos um dos candidatos da chapa deverá ser professor da carreira Magistério Público do Distrito Federal, com pelo menos três anos em regência de classe.

$\S 3^{\circ}$ Não serão considerados habilitados os candidatos que se encontram na situação descrita no art. $1^{\circ}$, I, e, itens 1 a 10 , f, g e h, da Lei Complementar federal $\mathrm{n}^{\circ}$ 64, de 18 de maio de 1990.

Art. 41. Os diretores e vice-diretores eleitos nos termos desta Lei terão mandato de três anos, o qual se iniciará no dia 2 de janeiro do ano seguinte ao da eleição, permitida reeleição para um único período subsequente.

Art. 42. Em caso de vacância do cargo, substituirão o diretor, sucessivamente, o vice-diretor e o servidor que vier a ser indicado pelo Conselho Escolar para este fim.

Parágrafo único. Vagando os cargos de diretor e vice-diretor antes de completados dois terços do mandato, será convocada nova eleição pela SEDF, no prazo de vinte dias, na forma desta Lei, e os eleitos completarão o período dos antecessores.

Art. 43. A exoneração do diretor ou do vice-diretor somente poderá ocorrer motivadamente após processo administrativo, nos termos da lei que dispõe sobre o regime jurídico dos servidores públicos, assegurado o contraditório e a ampla defesa.

$\S 1^{\circ} \mathrm{O}$ diretor e o vice-diretor terão a exoneração recomendada ao Governador do Distrito Federal, após deliberação de Assembleia Geral Escolar convocada pelo Conselho Escolar para este fim específico a partir de requerimento encaminhado ao presidente do Conselho, com assinatura de, no mínimo, cinquenta por cento dos representantes de cada um dos segmentos da comunidade escolar no colegiado.

$\S 2^{\circ}$ A Assembleia Geral Escolar de que trata o $\S 1^{\circ}$ será realizada quinze dias após o recebimento do requerimento, sendo de maioria absoluta de cada um dos dois segmentos da comunidade escolar o quórum para a abertura dos trabalhos, e de maioria simples o quórum para deliberação. Art. 44. Na hipótese de inexistência de candidato devidamente habilitado para compor chapa a fim de concorrer à eleição, a direção da unidade escolar será indicada pela SEDF, devendo o processo eleitoral ser repetido em até cento e oitenta dias e a direção eleita nesta hipótese exercer o restante do mandato.

Parágrafo único. Caso a unidade escolar não atinja o quórum mínimo na segunda tentativa de eleição, a equipe indicada pela SEDF deverá dirigir a unidade pelo restante do mandato.

Art. 45. Para cada unidade escolar recém-instalada, serão designados pela SEDF servidores para o exercício dos cargos de diretor e vice-diretor, devendo o processo eleitoral ser realizado em até cento e oitenta dias e a direção eleita nesta hipótese exercer o restante do mandato até a posse dos candidatos eleitos na eleição geral seguinte.

Parágrafo único. Na hipótese de criação de unidade escolar em ano de eleições gerais para diretor e vice-diretor, a equipe indicada na forma do caput permanecerá até a posse dos candidatos eleitos naquele processo eleitoral.

CAPÍTULO VI

DO PROCESSO ELEITORAL

Art. 46. As eleições para Conselho Escolar e para diretor e vice-diretor das instituições educacionais, que ocorrerão no mês de novembro, serão convocadas pela SEDF por meio de edital publicado na imprensa oficial e terão ampla divulgação.

Art. 47. O processo eleitoral, que terá regulamentação única para toda a Rede Pública de Ensino, será coordenado por Comissão Eleitoral Central, designada pela SEDF e assim constituída:

I - quatro representantes da SEDF;

II - um representante da entidade representativa dos servidores da carreira Magistério Público do Distrito Federal;

III - um representante da entidade representativa dos servidores da carreira Assistência à Educação Pública do Distrito Federal;

IV - um representante do segmento de pais, mães ou responsáveis por estudantes;

$\mathrm{V}$ - um representante de entidade representativa dos estudantes secundaristas do Distrito Federal.

$\S 1^{\circ}$ Não poderão compor comissão eleitoral candidatos a conselheiro escolar, a diretor ou a vice-diretor de instituições educacionais.

$\S 2^{\circ}$ São atribuições da Comissão Eleitoral Central, além das previstas na regulamentação desta Lei:

I - estabelecer a regulamentação única de que trata o caput e acompanhar sua implementação;

II - organizar o pleito;

III - atuar como instância recursal das decisões das Comissões Eleitorais Locais.

Art. 48. Em cada unidade escolar haverá uma Comissão Eleitoral Local constituída paritariamente por representantes da comunidade escolar, com as seguintes atribuições:

I - inscrever os candidatos;

II - organizar as apresentações e debates dos Planos de Trabalho para a Gestão da Escola;

III - divulgar edital com lista de candidatos, data, horário, local de votação e prazos para apuração e para recursos;

IV - designar mesários e escrutinadores, credenciar fiscais indicados pelos respectivos candidatos ou chapas concorrentes e providenciar a confecção de cédulas eleitorais;

$\mathrm{V}$ - cumprir e fazer cumprir as normas estabelecidas no regimento eleitoral;

VI - homologar as listas a que se refere o art. 49 desta Lei.

Parágrafo único. O Conselho Escolar designará os integrantes da Comissão Eleitoral Local.

Art. 49. Os eleitores de cada segmento constarão de lista elaborada pela secretaria escolar, a qual será encaminhada às comissões eleitorais e, quando solicitado, ao Conselho Escolar.

$\S 1^{\circ} \mathrm{A}$ lista de que trata o caput será tornada pública pela Comissão Eleitoral Local, em prazo não inferior a vinte dias da data da eleição.

$\S 2^{\circ}$ Os pais, mães ou responsáveis habilitados votarão independentemente de os seus filhos terem votado.

Art. 50. O quórum para eleição de diretor e vice-diretor e Conselho Escolar em cada unidade escolar será de:

I - cinquenta por cento para o conjunto constituído pelos eleitores integrantes da carreira Magistério Público do Distrito Federal, da carreira Assistência à Educação Pública do Distrito Federal e dos professores contratados temporariamente, conforme o art. $3^{\circ}$, VI a VIII;

II - dez por cento para o conjunto constituído pelos eleitores integrantes dos segmentos dos estudantes e dos pais, mães ou responsáveis, conforme o art. $3^{\circ}, \mathrm{I}$ a V.

$\S 1^{\circ}$ Não atingido o quórum para a eleição de diretor e vice-diretor, a unidade escolar terá sua direção indicada pela SEDF e nova eleição será realizada em até cento e oitenta dias. 
$\S 2^{\circ}$ Realizada nova eleição nos termos do $\S 1^{\circ}$ e persistindo a falta de quórum, a SEDF indicará a direção da unidade escolar que exercerá o restante do mandato.

$\S 3^{\circ}$ Não atingido o quórum para a eleição do Conselho Escolar, a SEDF organizará nova eleição em até cento e oitenta dias, repetindo-se o procedimento tantas vezes quantas forem necessárias, ressalvado o ano em que ocorrerem eleições gerais nos termos desta Lei.

Art. 51. Nas eleições para diretor e vice-diretor e para Conselho Escolar, os votos serão computados, paritariamente, da seguinte forma:

I - cinquenta por cento para o conjunto constituído pelos integrantes efetivos das carreiras Magistério Público do Distrito Federal e Assistência à Educação Pública do Distrito Federal e professores contratados temporariamente, conforme o art. $3^{\circ}$, VI a VIII;

II - cinquenta por cento para o conjunto constituído pelo segmento dos estudantes e dos pais, mães ou responsáveis por estudantes, conforme o art. $3^{\circ}$, I a V.

Art. 52. Na hipótese de empate, terá precedência:

I - a chapa em que o candidato a diretor apresentar maior tempo de efetivo exercício na unidade escolar para a qual esteja concorrendo;

II - o candidato a vaga de conselheiro escolar que contar com mais tempo como integrante na respectiva comunidade escolar.

Parágrafo único. Persistindo o empate, terá precedência o candidato mais idoso.

Art. 53. Durante o período de campanha eleitoral, são vedados:

I - propaganda de caráter político-partidário;

II - atividades de campanha antes do tempo estipulado pela Comissão Eleitoral Central;

III - distribuição de brindes ou camisetas;

IV - remuneração ou compensação financeira de qualquer natureza;

$\mathrm{V}$ - ameaça, coerção ou qualquer forma de cerceamento de liberdade.

Art. 54. Sem prejuízo das demais sanções cabíveis previstas na legislação, o descumprimento das vedações dispostas no art. 53 será punido com as seguintes sanções:

I - advertência escrita, no caso previsto no inciso II

II - suspensão das atividades de campanha por até cinco dias, no caso previsto no inciso III;

III - perda da prerrogativa de que trata o art. 62, no caso de reincidência das condutas previstas nos incisos II e III;

IV - exclusão do processo eleitoral corrente, nos casos previstos nos incisos I e IV e na reincidência das condutas previstas nos incisos II e III, na hipótese de a sanção prevista no inciso III deste artigo já ter sido aplicada;

$\mathrm{V}$ - proibição de participar, como candidato, dos processos eleitorais de que trata esta Lei por período de seis anos no caso previsto no inciso V.

$\S 1^{\circ}$ As sanções previstas nos incisos I e II serão aplicadas pela Comissão Eleitoral Local a que se refere o art. 48 e as sanções previstas nos incisos de III a V serão aplicadas pela Comissão Eleitoral Central.

$\S 2^{\circ}$ Das sanções aplicadas pela Comissão Eleitoral Local caberá recurso à Comissão Eleitoral Central.

$\S 3^{\circ}$ Das sanções aplicadas pela Comissão Eleitoral Central caberá recurso ao Secretário de Estado de Educação do Distrito Federal.

$\S 4^{\circ}$ Os recursos serão recebidos com efeito suspensivo e serão analisados e julgados no prazo máximo de três dias úteis.

\section{CAPÍTULO VII}

DAS DISPOSIÇÕES GERAIS E TRANSITÓRIAS

Art. 55. Esta Lei aplica-se a todas as instituições educacionais, de todos os níveis, mantidas pela SEDF, inclusive a Escola da Natureza, a Escola de Meninas e Meninos do Parque, a Escola do Parque da Cidade, as Escolas Parques, os Centros Interescolares de Línguas e outras escolas de modalidades especiais, preservadas as especificidades dessas instituições, na forma do regulamento.

Art. 56. Até seis meses após a publicação da lei que instituir o Plano Nacional de Educação, realizar-se-á a Conferência Distrital de Educação.

Art. 57. Na primeira investidura de membros do Conselho de Educação do Distrito Federal após a regulamentação desta Lei, metade dos conselheiros representantes do Poder Executivo, excetuados os membros natos, e metade dos demais conselheiros cumprirão mandato de dois anos.

Parágrafo único. A primeira investidura ocorrerá após o término do mandato dos atuais conselheiros.

Art. 58. O Poder Executivo encaminhará à Câmara Legislativa do Distrito Federal, no prazo de cento e oitenta dias, projeto de lei definindo as competências do Conselho de Educação do Distrito Federal.

Art. 59. A SEDF promoverá ampla divulgação dos processos eletivos

Art. 60. A SEDF oferecerá cursos de qualificação de, no mínimo, cento e oitenta horas aos diretores e vice-diretores eleitos, considerando os aspectos políticos, administrativos, financeiros, pedagógicos, culturais e sociais da educação no Distrito Federal.

Art. 61. A SEDF oferecerá curso de formação aos conselheiros escolares, conforme previsão do Programa Nacional de Fortalecimento dos Conselhos Escolares do Ministério da Educação ou de outra ação criada para este fim.

Art. 62. Nas quatro semanas que antecederem o pleito eleitoral, o candidato da carreira Magistério Público do Distrito Federal será liberado por dois horários de coordenação pedagógica por semana, e o da carreira Assistência à Educação do Distrito Federal será liberado de metade da sua jornada diária de trabalho duas vezes por semana.

Art. 63. Os candidatos em regência de classe, em função administrativa ou de gestão serão liberados de suas atividades vinte e quatro horas antes do pleito eleitoral.

Art. 64. O primeiro processo eleitoral para escolha dos dirigentes escolares deverá ocorrer até seis meses após a publicação desta Lei, e os seguintes ocorrerão sempre no mês de novembro do ano de realização das eleições de que trata esta Lei.

$\S 1^{\circ}$ A posse dos eleitos no pleito de que trata o caput ocorrerá até trinta dias após a homologação dos resultados pelo Secretário de Estado de Educação.

$\S 2^{\circ} \mathrm{O}$ mandato dos primeiros diretores, vice-diretores e membros dos Conselhos Escolares eleitos com base nesta Lei se encerrará em dezembro de 2013, e a eleição para o mandato seguinte ocorrerá no mês de novembro de 2013.

$\S 3^{\circ} \mathrm{A}$ direção das instituições educacionais coordenará o processo de formação da Comissão Eleitoral Local para o primeiro processo eleitoral, observado o disposto no art. 48 .

$\S 4^{\circ}$ As eleições para diretor e vice-diretor, bem como para o Conselho Escolar, deverão ser realizadas em dias letivos

$\S 5^{\circ}$ As eleições dos Centros de Línguas e Escolas Parques serão realizadas na escola de origem do estudante.

Art. 65. O Conselho de Educação do Distrito Federal, no prazo de cento e oitenta dias a contar da publicação desta Lei, promoverá a adequação de suas resoluções à legislação vigente.

Art. 66. Esta Lei entra em vigor na data de sua publicação.

Art. 67. Revogam-se as disposições em contrário, especialmente a Lei n 2.383 , de 20 de maio de 1989 , e os arts. $1^{\circ}$ a 23 e 27 a 30 da Lei ${ }^{\circ}$ 4.036 , de 25 de outubro de 2007. 
ANEXO ÚNICO

COMPOSIÇÃO DOS CONSELHOS ESCOLARES

(PARÁGRAFO ÚNICO DO ART. 24)

\begin{tabular}{|c|c|c|c|c|c|c|}
\hline \multirow{3}{*}{$\begin{array}{c}\text { Classificação das } \\
\text { instituições } \\
\text { educacionais }\end{array}$} & \multicolumn{6}{|c|}{ Número de membros do Conselho Escolar } \\
\hline & \multirow{2}{*}{$\begin{array}{r}\text { Equipe } \\
\text { Gestora } \\
\text { (direção) }\end{array}$} & \multicolumn{5}{|c|}{ Segmentos da comunidade escolar } \\
\hline & & $\begin{array}{c}\text { Carreira } \\
\text { Magistério/ } \\
\text { especialistas }\end{array}$ & $\begin{array}{c}\text { Carreira } \\
\text { Assistência }\end{array}$ & Estudantes & $\begin{array}{c}\text { Pais ou } \\
\text { responsáveis }\end{array}$ & $\begin{array}{c}\text { Total de } \\
\text { conselheiros }\end{array}$ \\
\hline Até 500 & 01 & 01 & 01 & 01 & 01 & 05 \\
\hline De 501 a 1000 & 01 & 02 & 02 & 02 & 02 & 09 \\
\hline De 1001 a 2000 & 01 & 03 & 03 & 03 & 03 & 13 \\
\hline De 2001 a 3000 & 01 & 04 & 04 & 04 & 04 & 17 \\
\hline Acima de 3000 & 01 & 05 & 05 & 05 & 05 & 21 \\
\hline
\end{tabular}




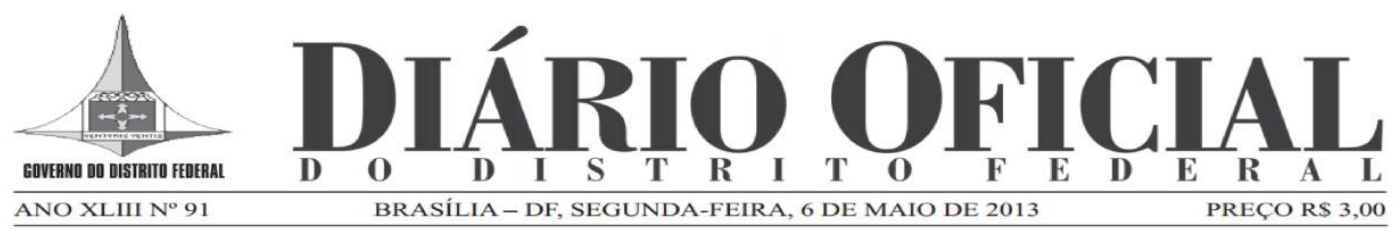

ATOS DO PODER EXECUTIVO

Lei $\mathrm{n}$ 0 5.105, de 03 de maio de 2013

(Autoria do Projeto: Poder Executivo)

Reestrutura a carreira magistério Público do Distrito Federal e dá outras providências.

O GOVERNADOR DO DISTRITO FEDERAL, FAÇO SABER QUE A CÂMARA LEGISLATIVA DO DISTRITO FEDERAL DECRETA E EU SANCIONO A SEGUINTE LEI:

\section{CAPÍTULO I \\ DAS DISPOSIÇÕES INICIAIS}

Art. 10 A carreira Magistério Público fica reestruturada na forma desta Lei.

Parágrafo único. O quantitativo de cargos da carreira de que trata este artigo é distribuído na forma do Anexo I.

\section{CAPÍTULO II \\ DA ORGANIZAÇÃO \\ Seção I \\ Dos Conceitos Básicos}

Art. 2\% Para efeitos desta Lei, considera-se:

I - cargo: o conjunto de atribuições e de responsabilidades previstas na estrutura organizacional que devem ser cometidas ao servidor;

II - carreira: o conjunto de cargos de natureza semelhante, distribuídos de acordo com a sua responsabilidade e a sua complexidade;

III - professor de educação básica: o titular de cargo da carreira magistério Público com atribuições que abrangem as funções de magistério e as atividades pedagógicas;

IV - pedagogo-orientador educacional: o titular de cargo da carreira magistério Público com atribuições que abrangem as funções de orientação educacional;

$\mathrm{V}$ - atividades pedagógicas: as atividades desenvolvidas por servidor da carreira magistério Público em docência na educação básica ou na formação continuada na Secretaria de Estado de Educação, direção, vice-direção e supervisão nas unidades escolares, orientação educacional, coordenação educacional, coordenação de estágio, suporte técnico-pedagógico, e atividades desenvolvidas em laboratórios e salas de leitura;

VI - área de atuação: a área da educação básica em que o servidor desenvolve suas atividades; VII - qualificação profissional: o aprimoramento do servidor com vistas à formação continuada e ao desenvolvimento na carreira;

VIII - progressão funcional: a progressão horizontal e vertical do servidor integrante da carreira magistério Público;

IX - coordenação pedagógica: o conjunto de atividades destinadas à qualificação, à formação continuada e ao planejamento pedagógico que, desenvolvidas pelo docente, dão suporte à atividade de regência de classe;

X - habilitação: a qualificação em área de formação específica em graduação, especialização, mestrado e doutorado; 
XI - padrão: a posição do servidor na escala de progressão vertical;

XII - etapa: a posição do servidor na escala de progressão horizontal;

XIII - progressão vertical: a passagem do padrão em que se encontra o servidor para os padrões subsequentes, considerando-se o tempo de serviço na carreira magistério Público ou a formação continuada;

XIV - progressão horizontal: a passagem da etapa em que se encontra o servidor para as subsequentes, considerando-se as alterações na sua habilitação;

XV - carga horária especial: a ampliação da carga horária do servidor de vinte para quarenta horas semanais;

XVI - vencimento básico inicial: a percepção pecuniária equivalente ao primeiro padrão da carreira magistério Público, conforme a carga horária e a habilitação do servidor;

XVII - remuneração: o valor mensal recebido pelo servidor, na forma da Lei Complementar $\mathrm{n}$ ㅇ 840, de 23 de dezembro de 2011.

\section{Seção II \\ Da Estrutura}

Art. 3ㅇ A carreira magistério Público é composta pelos seguintes cargos:

I- professor de educação básica;

II - pedagogo-orientador educacional.

$\S 1$ 을 As atribuições dos cargos de que trata este artigo são definidas em ato conjunto da Secretaria de Estado de Administração Pública e da Secretaria de Estado de Educação.

$\S 2$ o Os cargos de professor de educação básica e de pedagogo-orientador educacional organizam-se em padrões, etapas e vencimentos, na forma da tabela definida nos Anexos II, III, IV, V, VI e VII, observados os regimes de trabalho, a habilitação do servidor e as datas de vigência nelas especificadas.

\section{Seção III \\ Do Ingresso, da Habilitação e da Lotação}

Art. 40 O ingresso na carreira magistério Público dá-se, exclusivamente, por concurso público de provas e títulos, no padrão inicial da etapa III, atendidos os seguintes requisitos de escolaridade:

I - professor de educação básica: habilitação específica, obtida em curso superior com licenciatura plena ou bacharelado com complementação pedagógica, nas seguintes áreas de atuação: anos iniciais e finais do Ensino Fundamental, Ensino Especial, Educação Infantil, 1으, 2응 e 3오 segmentos da Educação de Jovens e Adultos, Ensino Médio e Educação Profissional;

II - pedagogo-orientador educacional: formação em curso superior em Pedagogia, desde que habilitado ou pós-graduado em Orientação Educacional, nas seguintes áreas de atuação: anos iniciais e finais do Ensino Fundamental, Ensino Especial, Educação Infantil, 1ㅇ, 2으 e 3은 segmentos da Educação de Jovens e Adultos, Ensino Médio e Educação Profissional.

$\S$ 1 Desde que habilitado, o professor de educação básica pode, sem for de seu interesse, atuar em área distinta daquela de sua habilitação inicial, respeitados os critérios de conveniência e oportunidade da Administração.

§ 2ㅇ O disposto no $\S 1$ 엉 deve ser observado quando da regulamentação prevista no art. 10 , 2으.

§ 3ㅇ O servidor da carreira magistério Público tem lotação na Coordenação Regional de Ensino e exercício nas unidades escolares a ela subordinadas, nas instituições conveniadas da rede pública de ensino, bem como nas unidades da estrutura administrativa e pedagógica da Secretaria de Estado de Educação. 
§ 4ำ A mudança de lotação e de exercício dos servidores da carreira magistério Público do Distrito Federal, mediante remanejamento, é realizada anualmente, conforme norma específica editada pela Secretaria de Estado de Educação.

\section{Seção IV}

\section{Do Posicionamento na Carreira}

Art. 5o Para o posicionamento na carreira, considera-se tempo de efetivo exercício, apurado em dias, o exercido:

I - na carreira magistério Público do Distrito Federal;

II - em qualquer dos Poderes do Distrito Federal, na condição de requisitado ou cedido, desde que concomitantemente ocupante de cargo efetivo da carreira magistério Público do Distrito Federal;

III - no magistério Público da união, dos estados e dos municípios, quando averbado, o qual somente é computado após quatro anos de efetivo exercício na carreira magistério Público do Distrito Federal.

$\S 1$ 10 Quando ocorrer o atendimento do requisito previsto no inciso III, o tempo de serviço é computado na razão de um dia de efetivo serviço prestado no órgão anterior para cada dia trabalhado na carreira magistério Público do Distrito Federal.

§ 20 O tempo de serviço de que trata o inciso III que exceder a quatro anos é computado na carreira a cada seis meses, observada a razão prevista no $\S 1$ ㅇ.

§ 3ㅇ Para efeito do disposto neste artigo, são considerados como efetivo exercício os afastamentos previstos no art. 165 da Lei Complementar no 840, de 2011.

Art. 60 Os atuais integrantes da carreira Magistério Público ficam posicionados na tabela de escalonamento vertical de que trata o Anexo II no mesmo padrão em que se encontram na data da publicação desta Lei.

Art. 70 Os atuais integrantes da carreira Magistério Público ficam posicionados nas tabelas de escalonamento horizontal de que trata o Anexo II, conforme segue:

I - Etapa I: professor de educação básica com formação em nível médio, com curso normal;

II - Etapa II: professor de educação básica com formação em nível superior, com licenciatura curta;

III - Etapa III: professor de educação básica com formação em nível superior, com licenciatura plena, e pedagogo-orientador educacional;

IV - Etapa IV: professor de educação básica e pedagogo-orientador educacional, com especialização;

V - Etapa V: professor de educação básica e pedagogo-orientador educacional, com mestrado;

VI - Etapa VI: professor de educação básica e pedagogo-orientador educacional, com doutorado.

Art. 8 Aplica-se o disposto nos arts. 5ㅇ e 6을 aos servidores remanescentes do quadro suplementar, sendo-lhes vedadas as progressões vertical e horizontal.

\section{Seção V \\ Da Carga Horária}

Art. 90 A carga horária de trabalho do servidor da carreira magistério Público do

Distrito Federal é de:

I - vinte horas semanais em um turno;

II - quarenta horas semanais em dois turnos.

§ 10 A carga horária semanal de trabalho do servidor da carreira magistério Público deve ser expressa no Termo de Posse do cargo efetivo, assinado pelo servidor e por representante da Secretaria de Estado de Educação, observada a conveniência da Administração, bem como a dotação orçamentária. 
§ 20 Fica admitida a redução da carga horária semanal de quarenta para vinte horas, mediante solicitação do servidor, observada a regulamentação da Secretaria de Estado de Educação.

§ 3o Fica admitida a ampliação da carga horária semanal de vinte para quarenta horas, mediante solicitação do servidor, desde que existam carências definitivas e disponibilidade orçamentária.

§ 40 $\mathrm{Na}$ ampliação da carga horária semanal de vinte para quarenta horas, observada a necessidade da Secretaria de Estado de Educação e a disponibilidade orçamentária, deve ser dada prioridade ao servidor com maior tempo em regência de classe.

§ 50 O servidor da carreira magistério Público, após o vigésimo ano em regência de classe, faz jus à redução da carga horária em regência de classe, no percentual de vinte por cento, a pedido, a partir do vigésimo primeiro ano, sem prejuízo da remuneração.

§ 60 A carga horária reduzida de que trata o $\S 50$ deve ser complementada em atividades de coordenação pedagógica e formação continuada.

§ 70 O professor deve solicitar a redução de carga horária de que trata o § 50 no prazo mínimo de sessenta dias anteriores ao final de cada semestre, ficando assegurada a referida redução para o semestre seguinte, observadas as normas editadas pela Secretaria de Estado de Educação.

Art. 10. Ficam assegurados ao professor de educação básica, em regência de classe nas unidades escolares, os seguintes percentuais mínimos de coordenação pedagógica:

I - trinta e três por cento para regime de trabalho de vinte horas semanais;

II - trinta e sete e meio por cento para regime de trabalho de quarenta horas semanais.

§ 1 O O professor de educação básica submetido ao regime de quarenta horas semanais, em dois turnos de vinte horas, tem, para cada turno, o disposto no inciso I.

§ 20 A distribuição da carga horária, bem como a sua alteração, o turno de trabalho e a coordenação pedagógica, são objeto de normas editadas pela Secretaria de Estado de Educação, devendo o período de coordenação pedagógica ser dedicado a atividades de qualificação, formação continuada e planejamento pedagógico.

\section{CAPÍTULO III \\ DO DESENVOLVIMENTO FUNCIONAL Seção I \\ Da Qualificação Profissional}

Art. 11. A Secretaria de Estado de Educação deve implementar, para os servidores em estágio probatório, curso de integração à carreira Magistério Público e programas de acompanhamento e avaliação.

Art. 12. Aos servidores da carreira magistério Público do Distrito Federal em exercício são proporcionados programas de formação continuada, sem prejuízo das atividades pedagógicas, com o objetivo de reelaborar os saberes iniciais da formação docente e de fomentar práticas educativas para a melhoria da qualidade do ensino, mediante norma própria.

§ 1ㅇ Os programas de formação continuada são oferecidos, com base em levantamento prévio das necessidades e prioridades da Secretaria de Estado de Educação, pela Escola de Aperfeiçoamento dos Profissionais da Educação do Distrito Federal - EAPE, por entidade de classe ou instituição externa, preferencialmente pública, aprovada em processo de credenciamento, e devem ser realizados no horário de trabalho do servidor.

§ 20 O processo de credenciamento e definição de cursos, diretrizes e demandas de que trata o § 1 o fica a cargo da EAPE.

§ 3o Fica garantido, anualmente, o afastamento remunerado de, no mínimo, um por cento dos servidores ativos para a realização de cursos de mestrado ou de doutorado, a título de formação continuada, respeitados os critérios de conveniência e oportunidade da Administração, garantida a remuneração do cargo, percebida no ato do afastamento, conforme norma editada pela Secretaria de Estado de Educação. 
Art. 13. Constituem incentivos profissionais a ser estabelecidos pela Secretaria de Estado de Educação as produções técnico-científicas e culturais dos servidores da carreira Magistério Público, desde que voltadas para a melhoria da qualidade do ensino e a valorização do magistério.

§ 1을 Os servidores da carreira magistério Público terão apoio para publicar os trabalhos de conteúdo técnico-pedagógico objeto de pesquisa ou produção acadêmica.

§ 2ㅇ O disposto neste artigo deve ser regulamentado em até cento e oitenta dias da publicação desta Lei.

\section{Seção II}

Da Progressão

Art. 14. A progressão do servidor na carreira magistério Público do Distrito Federal dá-se de forma vertical e horizontal.

§ 1ㅇ A progressão vertical ocorre de duas formas:

I - por tempo de serviço, desde que cumpridos os requisitos estabelecidos no art. 15, I;

II - por formação continuada, mediante requerimento do servidor.

§ 2ㅇ A progressão horizontal deve ser requerida pelo servidor, mediante apresentação de diploma de graduação, certificado ou título de especialização, mestrado ou doutorado, e sua vigência dá-se a partir do primeiro dia do mês subsequente ao mês em que foi requerida, observados os requisitos do art. 16.

§ 3 Para a progressão vertical por formação continuada, o servidor pode apresentar o título de especialização, mestrado ou doutorado já apresentado para a progressão horizontal, desde que cursado durante o interstício referente àquela progressão.

Art. 15. São requisitos essenciais para a concessão da progressão vertical:

I- por tempo de serviço:

a) encontrar-se em efetivo exercício;

b) cumprir o interstício de trezentos e sessenta e cinco dias de efetivo exercício no mesmo padrão;

II - por formação continuada:

a) encontrar-se em efetivo exercício;

b) cumprir, a cada cinco anos de efetivo exercício, o disposto no art. 14, § 1으. II, acompanhado de certificado de cursos na área de atuação, totalizando carga horária de cento e oitenta horas-aula, conforme norma editada pela Secretaria de Estado de Educação.

§ 10 Para fins do disposto neste artigo, são considerados os interstícios em curso na data de publicação desta Lei.

§ 2o Cumpridos os requisitos previstos neste artigo, mediante requerimento do servidor, pode haver progressão vertical por tempo de serviço e por formação continuada concomitantemente.

Art. 16. Para a progressão horizontal, prevista nas tabelas de que trata o Anexo II, os servidores da carreira magistério Público devem atender, concomitantemente, aos seguintes requisitos:

I - solicitar a progressão mediante requerimento;

II - encontrar-se em efetivo exercício;

III - apresentar diploma ou título correspondente à habilitação requerida, de instituição de ensino superior reconhecida pelo ministério da Educação.

\section{CAPÍTULO IV \\ DA REMUNERAÇÃo \\ Seção I \\ Dos Vencimentos}


Art. 17. Os vencimentos dos cargos de professor de educação básica e de pedagogo-orientador educacional da carreira magistério Público do Distrito Federal são compostos das seguintes parcelas:

I - Vencimento Básico, na forma dos Anexos II, III, IV, V, VI e VII, observados os regimes de trabalho, a habilitação do servidor e as datas de vigência neles especificadas;

II - Gratificação de Regência de Classe - GARC, que é modificada e passa a chamar-se Gratificação de Atividade Pedagógica - GAPED, calculada no percentual de trinta por cento do vencimento básico do padrão e da etapa em que o servidor esteja posicionado, observadas as condições de que trata o art. 18;

III - Gratificação de Atividade de Alfabetização - GAA, que passa a ser calculada no percentual de quinze por cento do vencimento básico do padrão I da etapa em que o servidor esteja posicionado;

IV - Gratificação de Atividade de Ensino Especial - GAEE, que passa a ser calculada no percentual de quinze por cento do vencimento básico do padrão I da etapa em que o servidor esteja posicionado;

V - Gratificação de Atividade em Zona Rural - GAZR, passa a ser calculada no percentual de quinze por cento do vencimento básico do padrão I da etapa em que o servidor esteja posicionado;

VI - Gratificação de Atividade de Suporte Educacional - GASE, calculada no percentual de trinta por cento do vencimento básico do padrão e da etapa em que o servidor esteja posicionado;

VII - Gratificação de Atividade de Dedicação Exclusiva em Tempo Integral no Magistério TIDEM, que é modificada e passa a denominar-se Gratificação de Tempo Integral - GTI, é calculada sobre o vencimento básico do padrão e da etapa em que o servidor esteja posicionado e tem seu percentual alterado na forma que segue:

a) trinta por cento a partir de 10 de março de 2013;

b) quinze por cento a partir de 10 de setembro de 2013;

c) fica extinta a partir de 1 을 de março de 2014;

VIII - Gratificação de Atividade de Docência em Estabelecimento de Ensino Diferenciado -

GADEED, que passa a ser calculada no percentual de quinze por cento do vencimento básico do padrão I da etapa em que o servidor esteja posicionado;

IX - Gratificação de Atividade de Docência em Estabelecimento de Restrição de Liberdade GADERL, que passa a denominar-se Gratificação de Atividade de Docência em Estabelecimento de Restrição e Privação de Liberdade - GADERL, calculada no percentual de quinze por cento do vencimento básico do padrão I da etapa em que o servidor esteja posicionado.

Parágrafo único. Os servidores da carreira magistério Público deixam de perceber a parcela individual fixa de que trata a Lei no 3.172, de 11 de julho de 2003, e a parcela complementar prevista no art. 30 da Lei 4.075, de 28 de dezembro de 2007, a partir de 1 ㅇ de março de 2013.

\section{Seção II \\ Das Condições de Percepção das Gratificações}

Art. 18. Fazem jus ao recebimento da GAPED os professores de educação básica:

I - que, no efetivo exercício, estejam desempenhando atividades de docência na educação básica ou na formação continuada na Secretaria de Estado de Educação e de coordenação pedagógica local;

II - ocupantes dos cargos de diretor, vice-diretor e supervisor em exercício nas unidades escolares da rede pública de ensino do Distrito Federal;

III - em atividades pedagógicas nas unidades centrais e intermediárias, entidades conveniadas ou parceiras formalmente constituídas, conforme norma específica editada pela Secretaria de Estado de Educação;

IV - atuantes em laboratório de informática e laboratório de ciências; 
$\mathrm{V}$ - atuantes em salas de leitura;

$\mathrm{VI}$ - atuantes como coordenadores de estágio;

VII - atuantes como apoio pedagógico;

VIII - afastados nos termos do art. 12, § 3으, na forma a ser disciplinada pela Secretaria de Estado de Educação;

IX - afastados para o exercício de mandato classista.

Art. 19. Fazem jus ao recebimento da GAA os professores de educação básica que, no efetivo exercício de regência de classe, alfabetizem crianças, jovens ou adultos nas unidades escolares da rede pública de ensino do Distrito Federal, nas instituições conveniadas ou parceiras formalmente constituídas.

Art. 20. Fazem jus ao recebimento da GAEE os integrantes da carreira magistério Público do Distrito Federal:

I - que atendam exclusivamente a alunos portadores de necessidades educativas ou em situações de risco e vulnerabilidade, em exercício nas unidades especializadas da rede pública de ensino do Distrito Federal, nas instituições conveniadas ou parceiras formalmente constituídas;

II - em exercício de regência nas unidades escolares de ensino regular que atuem nas modalidades especializadas de atendimento em Classes Especiais, Salas de Recurso e de Apoio à Aprendizagem e nas Equipes Especializadas de Apoio à Aprendizagem;

III - que atendam adolescentes e adultos com restrição e privação de liberdade nos núcleos de ensino das unidades de internação do Sistema Socioeducativo ou das unidades prisionais do Sistema Penitenciário do Distrito Federal, na Escola do Parque da Cidade - PROEM e na Escola dos meninos e meninas do Parque.

Parágrafo único. O disposto nos incisos II e III não se aplica ao professor regente de classes regulares que atenda alunos com necessidades especiais de forma inclusiva.

Art. 21. Fazem jus ao recebimento da GAZR os servidores da carreira magistério Público que estejam em efetivo exercício em unidades escolares situadas na zona rural do Distrito Federal.

Art. 22. Fazem jus ao recebimento da GASE os ocupantes do cargo de pedagogo-orientador educacional:

I - que, no efetivo exercício, estejam desempenhando atividades nas unidades escolares da rede pública do Distrito Federal ou de formação continuada na Secretaria de Estado de Educação;

II - ocupantes dos cargos de diretor, vice-diretor e supervisor em exercício nas unidades escolares da rede pública de ensino do Distrito Federal;

III - em atividades pedagógicas nas unidades centrais e intermediárias, entidades conveniadas ou parceiras formalmente constituídas, na forma das normas editadas pela Secretaria de Estado de Educação;

IV - afastados nos termos do art. 12, § 3으, na forma a ser disciplinada pela Secretaria de Estado de Educação;

$\mathrm{V}$ - afastados para o exercício de mandato classista.

Art. 23. Fazem jus ao recebimento da GADEED os integrantes da carreira magistério Público que estejam em efetivo exercício nos Estabelecimentos de Ensino Diferenciado.

Parágrafo único. São considerados Estabelecimentos de Ensino Diferenciado, para efeito desta Lei, a Escola do Parque da Cidade - PROEM e a Escola dos meninos e meninas do Parque.

Art. 24. Fazem jus ao recebimento da GADERL os integrantes da carreira magistério Público que estejam em efetivo exercício nos Estabelecimentos de Restrição e Privação de Liberdade.

§ 1 São considerados Estabelecimentos de Restrição e Privação de Liberdade, para efeito desta Lei, os núcleos de ensino das unidades de internação do Sistema Socioeducativo e de internação estrita das unidades prisionais do Sistema Penitenciário do Distrito Federal.

§ 20 O número de vagas para exercício de professores de educação básica nas unidades do Sistema Penitenciário do Distrito Federal fica limitado a sessenta, sendo permitida a ampliação, caso seja devidamente comprovado o aumento da demanda. 
Art. 25. A GTI é concedida aos servidores da carreira Magistério Público submetidos à carga horária mínima de quarenta horas semanais, em um ou dois cargos dessa carreira, desde que estejam em efetivo exercício na Secretaria de Estado de Educação, nas instituições conveniadas ou parceiras formalmente constituídas.

§ 1ㅇ A incorporação da TIDEM, quando da publicação desta Lei, será absorvida na mesma proporção estabelecida no art. 17, VII.

§ 2 A extinção da TIDEM e a criação da GTI não implica redução da remuneração.

Art. 26. As gratificações estabelecidas nos arts. de 18 a 25 podem ser percebidas cumulativamente, desde que observadas as condições para a concessão, e estão sujeitas à contribuição previdenciária.

Art. 27. Os professores de educação básica readaptados fazem jus a todas as gratificações percebidas na data do afastamento de que resulte a readaptação, desde que atendidas as condições necessárias ao seu recebimento, exceto a GAZR.

Art. 28. Os pedagogos-orientadores educacionais readaptados fazem jus a todas as gratificações percebidas na data do afastamento de que resulte a readaptação, desde que atendidas as condições necessárias ao seu recebimento, exceto a GAZR.

Art. 29. Fazem jus ao recebimento das Gratificações de que tratam os arts. de 18 a 25 os servidores da carreira magistério Público que se afastem nos casos previstos em lei ou no art. 165 da Lei Complementar no 840, de 2011.

Parágrafo único. Excetua-se do disposto neste artigo o art. 165, V, a, da Lei Complementar no 840, de 2011.

Art. 30. As gratificações definidas nos arts. de 18 a 24 são incorporadas na razão de um vinte e cinco avos por ano de efetivo exercício, até o limite de sua totalidade, por ocasião da aposentadoria do servidor.

Parágrafo único. O disposto neste artigo aplica-se às aposentadorias e pensões concedidas anteriormente à vigência desta Lei, observadas as condições destacadas.

Art. 31. As gratificações definidas nos arts. de 18 a 24 são incorporadas na razão de um vinte e cinco avos por ano de efetivo exercício, até o limite de sua totalidade, ao servidor da carreira magistério Público que deixar de desempenhar as atividades previstas nos arts. de 18 a 24 .

\section{Seção III \\ Das Férias e Recessos}

Art. 32. O período de férias do servidor da carreira magistério Público é de trinta dias anuais, nos termos da legislação específica.

§ 10 Os professores de educação básica em regência de classe, os readaptados, os coordenadores pedagógicos locais e os pedagogos-orientadores educacionais em exercício nas unidades escolares, na EAPE e nas instituições conveniadas gozam férias e recessos escolares coletivamente, na forma estabelecida pelo calendário escolar elaborado pela Secretaria de Estado de Educação.

§ 2ㅇ Fica assegurado aos servidores da carreira magistério Público em exercício nas instituições conveniadas o disposto no $\S 1 \stackrel{0}{ }$, caso haja coincidência do calendário escolar da instituição conveniada.

§ 30 Os demais servidores da carreira magistério Público gozam férias de acordo com a conveniência da Secretaria de Estado de Educação.

Art. 33. Os servidores da carreira magistério Público em exercício nas unidades administrativas e pedagógicas dos níveis intermediário e central da Secretaria de Estado de Educação têm recesso de cinco dias corridos, a serem gozados entre o primeiro e segundo semestre letivo.

Art. 34. Os servidores da carreira magistério Público em exercício nas unidades escolares e na EAPE têm recessos de quinze dias corridos, a serem gozados entre o primeiro e o segundo semestre letivo, e de sete dias corridos, a serem gozados entre o segundo semestre letivo e o primeiro semestre letivo do ano subsequente. 
§ 10 Fica assegurado aos servidores da carreira magistério Público em atividade de regência de classe nas instituições conveniadas o disposto neste artigo.

§ 20 Para atender ao interesse público e assegurar o cumprimento de duzentos dias letivos, o número de dias de recesso escolar pode ser alterado por ato fundamentado do Secretário de Estado de Educação.

Art. 35. Na hipótese de o servidor encontrar-se em licença médica ou licença-maternidade na data de início das férias coletivas, estas serão usufruídas imediatamente após o término da licença.

\section{Seção IV \\ Da Cessão}

Art. 36. A cessão de servidores da carreira magistério Público para a Administração Direta ou Indireta de qualquer dos Poderes do Distrito Federal, da união, de estados ou municípios dá-se exclusivamente para:

I - função de magistério;

II - os casos previstos na Lei Complementar № 840, de 2011.

Parágrafo único. O quantitativo de servidores cedidos fica limitado a um por cento do total de vagas previstas no Anexo I.

\section{CAPÍTULO V \\ DAS DISPOSIÇÕES FINAIS}

Art. 37. Fica transformada em Vantagem Pessoal Nominalmente Identificada - VPNI a parcela relativa à Complementação Salarial Temporária prevista no art. 25 da Lei 4.075, de 2007, recebida pelo servidor da carreira magistério Público em 28 de fevereiro de 2013.

Art. 38. Fica absorvida a parcela complementar prevista no art. 30 da Lei 4.075, de 2007, recebida pelo servidor da carreira magistério Público em 28 de fevereiro de 2013.

Art. 39. Nenhuma redução de remuneração ou de proventos pode resultar da aplicação do conjunto de normas estabelecidas nesta Lei, sendo assegurada, na forma de Vantagem Pessoal Nominalmente Identificada - VPNI, a parcela correspondente à diferença eventualmente obtida, a qual será atualizada exclusivamente pelos índices gerais de reajuste dos servidores públicos distritais.

Parágrafo único. Ficam garantidas as VPNIs e a parcela de aperfeiçoamento existentes na data de publicação desta Lei.

Art. 40. Aplica-se o disposto nesta Lei, no que couber, aos servidores aposentados e aos pensionistas.

Art. 41. Mesa paritária constituída por representantes da Secretaria de Estado de Educação e do Sindicato dos Professores no Distrito Federal - SINPRO-DF deve propor regulamentação desta Lei, no que couber, no prazo máximo de trinta dias, contados da publicação.

Art. 42. Esta Lei entra em vigor na data de sua publicação, com efeitos financeiros a partir de 1ㅇ de março de 2013 e das datas que especifica.

Art. 43. Revogam-se as disposições em contrário, em especial:

I - a Lei $n=3.621$, de 14 de julho de 2005;

II - a Lei no 3.743, de 18 de janeiro de 2006;

III - a Lei no 4.075, de 28 de dezembro de 2007.

Brasília, 03 de maio de 2013.

125으 da República e 54ㅇ de Brasília

AGNELO QUEIROZ 
Dispõe sobre normas para Lotação, Exercício, Remanejamento Externo e Interno de servidores integrantes da Carreira Magistério Público do Distrito Federal e dá outras providências.

O SECRETÁRIO DE ESTADO DE EDUCAÇÃO DO DISTRITO FEDERAL, no uso de suas atribuições regimentais, considerando a Lei Complementar $n^{\circ} 840$, de 23 de dezembro de 2011, que institui o regime jurídico dos servidores públicos civis da administração direta, autárquica e fundacional do Distrito Federal, considerando a Lei $n^{\circ} .5 .105$, de 03 de maio de 2013, que dispõe sobre a Carreira Magistério Público do Distrito Federal; considerando a necessidade de definição de critérios para lotação, remanejamento externo e interno de servidores integrantes da Carreira Magistério Público do Distrito Federal, para que os interessados possam concorrer em igualdade de condições e; considerando o interesse da Administração na gestão de seus profissionais da educação, RESOLVE:

Art. $1^{\circ}$ Aprovar normas para lotação, exercício, remanejamento externo e remanejamento interno dos servidores integrantes da Carreira Magistério Público do Distrito Federal, constantes do Anexo Único desta Portaria.

Art. $2^{\circ}$ Atribuir à Subsecretaria de Gestão dos Profissionais da Educação; às Coordenações Regionais de Ensino e às Unidades Escolares, no que couber, a responsabilidade pela aplicação e operacionalização destas normas, bem como pelo seu controle e fiel observância.

Art. $3^{\circ}$ Esta Portaria entra em vigor na data de sua publicação, revogando-se a Portaria $\mathrm{n}^{\circ}$ 192, de 23 de julho de 2013, e demais disposições em contrário.

MARCELO AGUIAR

\section{ANEXO ÚNICO}

NORMAS PARA LOTAÇÃO, EXERCÍCIO, REMANEJAMENTO EXTERNO

E INTERNO DE SERVIDORES INTEGRANTES

DA CARREIRA MAGISTÉRIO PÚBLICO DO DISTRITO FEDERAL.

TÍTULO I

DAS CONSIDERAÇÕES PRELIMINARES

1 - Para efeito desta norma, entende-se por:

SEDF - Secretaria de Estado de Educação do Distrito Federal. 
SUGEPE - Subsecretaria de Gestão dos Profissionais da Educação.

SUBEB - Subsecretaria de Educação Básica.

CRE - Coordenação Regional de Ensino.

CPMOM - Coordenação de Provimento, Movimentação e Modulação.

COSAÚDE - Coordenação de Saúde Ocupacional.

COESP - Coordenação de Educação Especial.

GELOTEM - Gerência de Lotação e Movimentação.

GESMOP - Gerência de Modulação de Pessoas.

GPROF - Gerência de Gestão dos Profissionais da Educação.

UE - Unidade Escolar

UIS - Unidade de Internação Socioeducativa

CEP - Centro de Educação Profissional

SIGRH - Sistema Único de Gestão de Recursos Humanos

CARGA HORÁRIA - Jornada de trabalho que o servidor deve cumprir conforme legislação específica.

CARÊNCIA DEFINITIVA - Vaga decorrente da abertura de novas turmas e de afastamento definitivo de seu titular, quando não houver servidor da Carreira Magistério Público disponível em nenhuma esfera da administração pública que possa suprir a vaga.

CARÊNCIA PROVISÓRIA - Vaga decorrente do afastamento temporário de servidor da Carreira Magistério Público.

CARENCIA PERMANENTE - Vaga decorrente do afastamento temporário de servidor da Carreira Magistério Público designado como Diretor, Vice Diretor e Supervisor e ainda indicado a atuar como Coordenador Pedagógico Local, no âmbito da unidade escolar.

LOTAÇÃO - Coordenação Regional de Ensino em que o servidor possui lotação definitiva.

EXERCÍCIO - Local onde o servidor exerce suas atividades.

EXERCÍCIO PROVISÓRIO - Condição na qual se encontra o servidor quando não possuir lotação em nenhuma Coordenação Regional de Ensino.

CRE DE LOTAÇÃO - Coordenações Regionais de Ensino nas quais o servidor da Carreira Magistério Público adquire lotação, quando do seu encaminhamento na posse do cargo público e na efetivação do Procedimento de Remanejamento Externo ou permuta. São elas: 
Brazlândia, Ceilândia, Gama, Planaltina, Samambaia, Paranoá, Santa Maria, São Sebastião e Recanto das Emas.

CRE DE REMANEJAMENTO EXTERNO - Coordenações Regionais de Ensino nas quais o servidor da Carreira Magistério Público adquire lotação somente por Procedimento de Remanejamento Externo ou permuta. São elas: Plano Piloto, Guará, Núcleo Bandeirante, Sobradinho e Taguatinga.

HABILITAÇÃO - Área de formação na qual o servidor está formalmente habilitado a desenvolver suas atividades.

REMANEJAMENTO INTERNO - Mudança do local de exercício do servidor entre Unidades Escolares vinculadas a uma mesma Coordenação Regional de Ensino.

REMANEJAMENTO EXTERNO - Mudança do local de lotação do servidor entre Coordenações Regionais de Ensino.

REMANEJAMENTO DE OFÍCIO - Mudança do local de exercício do servidor entre Coordenações Regionais de Ensino, de caráter provisório, autorizado pela Secretaria de Estado de Educação/Subsecretaria de Gestão dos Profissionais da Educação.

SERVIDOR - Professor e Pedagogo-Orientador Educacional integrantes da Carreira Magistério Público do Distrito Federal.

\section{TÍTULO II}

\section{DA LOTAÇÃO}

2 - A lotação é adquirida por:

a) Ingresso na Secretaria de Estado de Educação quando, no dia da posse, for encaminhado para uma das CRE de lotação.

b) Ingresso na Secretaria de Estado de Educação quando, no dia da posse, for encaminhado para um CEP para atuar em um componente curricular exclusivo de concurso/atuação.

c) Procedimento de Remanejamento Externo, observado o disposto nesta Portaria e em Edital próprio.

2.1 - O servidor que, excepcionalmente, quando da posse, for encaminhado para uma CRE de Remanejamento Externo, será considerado exercício provisório, devolvido ao final do ano letivo e poderá atuar em qualquer CRE onde houver carência definitiva.

2.2 - O servidor que, na data de publicação desta Portaria, encontrar-se em exercício provisório nas CRE de lotação, adquirirá lotação nas respectivas CRE.

2.3 - O servidor que, na data de publicação desta Portaria, encontrar-se em exercício provisório no CEP/Escola de Música Levino de Alcâncatra e CEP/Escola Técnica de 
Brasília, tendo sido encaminhado para atuar em componente curricular exclusivo de concurso/atuação, adquirirá lotação nas respectivas CRE.

3 - O servidor que obtiver ampliação de carga horária de 20 (vinte) para 40 (quarenta) horas semanais adquirirá lotação na segunda carga, na CRE onde já possui lotação.

4 - O exercício definitivo na UE será dado, anualmente, após a escolha de turmas para a regência de classe.

4.1 - Só poderá participar da escolha de turmas o servidor que possuir exercício definitivo na UE no ano anterior e/ou advindo do Procedimento de Remanejamento.

4.2 - O servidor que não se enquadra no item 4.1 não terá o exercício definitivo garantido na UE e a carência definitiva será aberta no próximo Procedimento de Remanejamento.

5. Os demais servidores da Carreira Magistério que atuam nos diversos atendimentos previstos na modulação/estratégia de matrícula da UE (Sala de Recursos, Serviços de Apoio: Guia Intérprete e Intérprete, Itinerância/Educação Especial, Equipe Especializada de Apoio à Aprendizagem, Sala de Apoio à Aprendizagem e/ou Itinerância da Sala de Apoio à Aprendizagem, Pedagogo-Orientador Educacional), que possuírem lotação na CRE, somente terão assegurado o exercício definitivo, se tiverem participado da escolha de turmas, assinando a ata e especificando seu atendimento e área de atuação para o ano letivo.

5.1 - Só poderão participar da escolha de turmas, conforme prevê o item 5, os servidores que possuírem exercício definitivo na UE no ano anterior e/ou advindo do Procedimento de Remanejamento.

5.2 - O servidor que não se enquadra no item 5.1 não terá o exercício definitivo garantido na UE e a carência definitiva será aberta no próximo Procedimento de Remanejamento.

5.3 - Os servidores da Carreira Magistério de que trata o item 5 poderão atuar apenas no atendimento e/ou área ao qual foi encaminhado.

6 - Em caso de professor readaptado, o exercício na UE é dado considerando-se as atividades laborais para as quais o servidor estiver apto, conforme laudo de capacidade laborativa, assinando a ata e especificando sua atuação para o referido ano letivo.

7 - Em caso de fechamento de turmas e/ou atendimento da UE, após o início do ano letivo, o professor será devolvido à GPROF, para ser encaminhado para outra UE, nessa ordem:

a) professor substituto (temporário), caso haja;

b) professor requisitado de outro Estado da Federação;

c) professor em exercício provisório, com data de admissão mais recente na matrícula atual. Havendo mais de um professor nessa situação, será devolvido o que tiver maior classificação no concurso público; 
d) professor na condição de remanejado de ofício, com data de admissão mais recente na matrícula atual;

e) professor com lotação na CRE e exercício provisório na UE, com data de admissão mais recente na matrícula atual; f) professor com lotação na CRE e com exercício definitivo na UE, com menor pontuação no procedimento de escolha de turmas do ano letivo.

8 - O servidor terá assegurado o retorno à CRE de Lotação, quando:

a) retornar de afastamento previsto no artigo 132 da Lei Complementar $n^{\circ} 840$, de 23 de dezembro de 2011;

b) remanejado de ofício, conforme previsto no item 30.2;

c) da reversão de aposentadoria e da aposentadoria tornada sem efeito;

d) da reintegração, da recondução ou do retorno de vacância;

e) submeter-se a novo Concurso Público de Provas e Títulos, sendo exonerado sem interstício do cargo anterior.

9 - O servidor em exercício provisório que comparecer a SUGEPE/CPMOM/GELOTEM ao longo do ano letivo será encaminhado para uma CRE de lotação, preferencialmente a mais próxima da sua residência comprovada, onde haja carência definitiva.

10 - No início de cada ano letivo, as UE deverão devolver à GPROF os servidores da Carreira Magistério que estiverem em exercício provisório na UE ou que excederem após distribuição de carga horária por não haver carência, para que sejam realocados.

10.1 - Caso a equipe gestora da UE não devolver os servidores da Carreira Magistério excedentes, bem como os exercícios provisórios e remanejados de ofício, a SUGEPE determinará abertura de processo sindicante para apurar responsabilidade.

10.2 - Caso não haja carência na habilitação desejada pelo servidor a GPROF poderá encaminhá-lo para uma UE de acordo com as carências existentes e suas habilitações

10.3 - Caso não haja carência na CRE nas áreas de habilitação do servidor constante no SIGRH, e encontrar-se ainda excedente, ele será devolvido à SUGEPE/CPMOM/GELOTEM, para exercício provisório em outra $\mathrm{CRE}$, preferencialmente a mais próxima de sua residência comprovada, sendo-lhe garantido o retorno à CRE de origem, quando do surgimento de uma carência ou no final do ano letivo.

11 - Na alteração de vinculação da UE à outra CRE, o servidor em exercício definitivo na referida UE, terá transferida sua lotação para a nova CRE de vinculação.

11.1 - O servidor, na condição descrita no item 11, poderá efetuar opção de retorno para a CRE anterior, no último dia letivo de cada semestre do ano em que ocorreu a mudança de vinculação. 
12 - Os servidores que foram encaminhados aos Núcleos de Ensino das UIS por Termo de Cooperação Técnica, terão sua lotação na CRE de vinculação desta UE na data de publicação desta portaria.

12.1 - O servidor, na condição descrita no item 12, poderá efetuar opção de retorno para a sua CRE de origem, até 10 dias a contar da data de publicação desta norma e comparecer a CPMOM/ GELOTEM no último dia letivo.

TÍTULO III

\section{DO REMANEJAMENTO EXTERNO E INTERNO}

13 - O Remanejamento Externo dar-se-á por meio de:

a) procedimento de remanejamento;

b) permuta;

c) de ofício.

14 - O Remanejamento Interno dar-se-á por meio de:

a) procedimento de remanejamento;

b) permuta;

c) por motivo de saúde homologada pela COSAUDE;

d) por motivo segurança do servidor, devidamente comprovado.

\section{CAPÍTULO I}

\section{DOS PROCEDIMENTOS DE REMANEJAMENTO EXTERNO E INTERNO}

15 - Poderá concorrer ao Procedimento de Remanejamento Interno o servidor da Carreira Magistério que possui lotação na CRE ou seu procurador legal constituído por procuração.

15.1 - O servidor da Carreira Magistério que está investido em cargo em comissão ou em função gratificada poderá participar do Procedimento de Remanejamento Interno desde que obrigatoriamente assuma a carência bloqueada.

16 - Poderá concorrer ao Procedimento de Remanejamento Externo o servidor da Carreira Magistério desde que esteja atuando no âmbito da SEDF ou nas instituições conveniadas ou seu procurador legal constituído por declaração.

16.1 - O servidor da Carreira Magistério investido em cargo em comissão ou em função gratificada que participar do Procedimento de Remanejamento Externo e desejar continuar no cargo ou função, terá garantida a lotação adquirida no procedimento, desde que solicitada à SUGEPE/ CPMOM/GELOTEM em até 10 dias antes do início do ano letivo. 
17 - O servidor adquirirá lotação de acordo com sua carga horária de trabalho, de 20 ou 40 horas semanais, no Procedimento de Remanejamento Externo.

18 - A atuação do servidor de 40 horas semanais, seja jornada ampliada ou 20 mais 20, será definida no bloqueio da carência conforme critérios estabelecidos em edital próprio.

19 - O servidor poderá ser remanejado uma única vez no Procedimento de Remanejamento Externo ou Interno, comprometendo-se a assumir o exercício na UE e turno para o qual for contemplado.

20 - Caso o servidor optar por concorrer ao Procedimento de Remanejamento Externo e Interno e for contemplado nos dois procedimentos, prevalecerá o de Remanejamento Externo.

21 - O servidor que for remanejado, não poderá solicitar mudanças dentro das opções por ele indicadas e bloqueadas.

22 - Somente será dado exercício definitivo na UE para a qual o servidor for remanejado, após o procedimento de escolha de turma, se o professor for contemplado.

22.1 - Caso a carência definitiva deixe de existir comprovadamente, o servidor deverá ser devolvido imediatamente para novo exercício, sendo garantida a lotação na CRE.

22.2 - Caso seja do interesse do servidor que se encontre na situação descrita no item 22.1, ele poderá optar por retornar a situação anterior e ter o seu remanejamento tornado sem efeito, não sendo garantido o exercício na UE anterior.

23 - O servidor não poderá ser movimentado após de Procedimento de Remanejamento, exceto, nos casos de decisão judicial, comprovada necessidade por motivo de saúde ou segurança do servidor e os previstos no item 22.1.

23.1 - Caso o servidor seja movimentado com autorização expressa da SUGEPE e não se enquadre no item 23, este terá seu remanejamento tornado sem efeito.

23.2 - Será permitida a movimentação do servidor para atuar na Coordenação Pedagógica da UE em que ele bloqueou sua carência, respeitando o que dispõe a legislação de distribuição de carga horária.

24 - A efetivação do Procedimento de Remanejamento Externo e Interno dar-se-á no ato de sua realização, devendo o servidor remanejado apresentar-se na nova CRE de lotação, conforme os critérios estabelecidos em edital próprio.

25 - Compete à SUBEB constituir equipe para avaliar a aptidão do servidor interessado em concorrer nas áreas de ensino especificadas em edital próprio, conforme critérios préestabelecidos. 
26 - Compete à COSAÚDE avaliar os servidores com deficiência que não tenham ingressado na SEDF nesta condição.

\section{CAPÍTULO II}

\section{DO REMANEJAMENTO EXTERNO E INTERNO POR PERMUTA}

27 - Os Remanejamentos Externo e Interno por Permuta, poderão ocorrer entre dois ou mais servidores que se comprometerem a assumir as atividades por eles exercidas, observando-se, no ato da efetivação da permuta as seguintes situações:

a) ser servidor da Carreira Magistério;

b) estar em regência ou compondo um dos diversos atendimentos previstos na modulação da UE;

c) possuir habilitações compatíveis com as séries e/ou atendimentos nas quais irão atuar, se professores;

d) ter lotação na CRE de exercício;

e) possuir a carga horária compatível com a carência e a carga horária do permutante.

27.1 - Caso a permuta seja entre um professor em regência de classe e outro que compõe um dos diversos atendimentos previstos na modulação da UE, aquele deverá comprovar que se encontra apto a atuar no referido atendimento.

28 - O Remanejamento Externo e o Remanejamento Interno por Permuta será homologado pela SUGEPE/CPMOM/GELOTEM e CRE/GPROF, respectivamente nos primeiros trinta dias de cada semestre letivo, mediante preenchimento de formulário próprio.

28.1 - A permuta só poderá ser efetivada após a escolha de turmas e atendimentos.

28.2 - No caso de professor que teve seu exercício originado por permuta ocorrida durante o ano letivo, o permutante terá a pontuação contada apartir do atual exercício.

29 - A efetivação da permuta fica condicionada à conclusão dos trabalhos do servidor na UE em que estiver atuando.

29.1 - Quando da homologação da permuta será obrigatória a permanência do servidor na condição permutada até o final do ano letivo em que ela ocorreu.

29.2 - Se ocorrer de um dos permutantes se aposentar, solicitar exoneração ou tomar posse em outro cargo inacumulável, no prazo estipulado no item 29.1, a permuta será tornada sem efeito e o(s) servidor(es) retornará(ão) a sua CRE/UE de origem.

CAPÍTULO III

DO REMANEJAMENTO DE OFÍCIO 
30 - O Remanejamento de Ofício poderá ser solicitado pelo servidor, em formulário próprio, respeitando-se o interesse da Administração, quando for constatada sua real necessidade, devidamente justificada e comprovada, nas seguintes situações:

a) deficiência e/ou problemas de saúde do servidor, respaldado por parecer da COSAÚDE;

b) mãe, pai ou responsável por dependentes deficientes, respaldado por parecer da COSAÚDE, desde que haja carência na CRE pretendida;

c) suprimento de carências em regência de classe/atendimentos no âmbito das CRE;

d) atuação em atividades técnicas, pedagógicas ou administrativas nas sedes da SEDF e CRE;

e) por motivos de segurança.

30.1 - Os remanejamentos, previstos no item 30, são autorizados, exclusivamente pela Subsecretaria de Gestão dos Profissionais da Educação e condicionados à substituição.

30.2 - O servidor que se encontrar remanejado de ofício poderá ter sua devolução solicitada pela SUGEPE/CPMOM/GELOTEM a qualquer momento ou deverá, obrigatoriamente, ser devolvido a sua CRE de lotação ao término do ano letivo ou início do ano letivo subsequente, exceto nos casos de decisão judicial ou nas situações previstas no item 30, alíneas "a", "b" e "e".

30.3 - O servidor remanejado de ofício que se encontra nas situações previstas no item 30, alínea "a"e "b", será avaliado pela COSAÚDE a cada dois anos letivos.

30.4 - O remanejamento de ofício terá efeito apenas no início de cada semestre letivo, desde que solicitado até 30 dias antes do término do semestre letivo anterior, exceto nos casos de decisão judicial ou nas situações previstas no item 30, alíneas "a","b" e "e".

30.5 - Não poderá ser remanejamento de ofício o servidor que participar do Procedimento de Remanejamento, exceto nos casos de decisão judicial ou nas situações previstas no item 30, alíneas "a", "b" e "e".

31 - O servidor que se encontrar na condição de remanejado de ofício e desejar retornar à CRE de lotação, antes da data-limite estabelecida quando da autorização, poderá fazê-lo no final do semestre letivo, desde que haja carência, no interesse da Administração e condicionada à substituição.

TíTULO IV

DAS CARÊNCIAS

32 - São consideradas carências definitivas aquelas decorrentes das situações abaixo especificadas: 

a) abandono de cargo;
b) abertura de turmas;
c) aposentadoria;
d) exoneração/demissão;
e) falecimento;
f) readaptação;
g) decorrente dos Procedimentos de Remanejamento Interno e/ou Externo, quando o servidor ocupar carência definitiva;
h) licença para acompanhar cônjuge;
i) redução de carga horária de 40 horas para 20 horas semanais;
j) carências nos turnos matutino, vespertino ou noturno que totalizem no mínimo 12 horas/aula de regência de classe.

32.1 - Se essas carências surgirem após a data limite para o Procedimento de Remanejamento e/ou do procedimento de escolha de turma/atendimento, estas deverão, obrigatoriamente, ser apresentadas no próximo Procedimento de Remanejamento Externo.

33 - São consideradas carências provisórias as decorrentes das situações previstas no artigo 132 da Lei Complementar $\mathrm{n}^{\mathbf{0}}$ 840, de 23 de dezembro de 2011 e as oriundas de movimentações internas, no âmbito da SEDF, especificadas abaixo:

a) afastamento para exercício de mandato eletivo;

b) afastamento para exercício de cargo comissionado no âmbito dos Poderes;

c) afastamento para servir em outro órgão ou entidade conveniada ou não;

d) afastamento remunerado para estudos acima de 06 meses;

e) licença para o serviço militar;

f) licença para tratar de interesses particulares;

g) licença para o desempenho de mandato classista;

h) exercício de atividades técnicas, pedagógicas ou administrativas;

i) remanejado de ofício, com autorização expressa da SUGEPE;

j) remanejado no âmbito da CRE, com autorização expressa da SUGEPE. 
33.1 - Se as carências apresentadas acima e as carências definitivas apresentadas no item 32, surgirem após a data limite para o Procedimento de Remanejamento e/ou o procedimento de escolha de turma/atendimento, estas deverão obrigatoriamente ser apresentadas no próximo Procedimento de Remanejamento Interno.

34 - São consideradas carências permanentes aquelas decorrentes de substituições de:

a) Diretor;

b) Vice-Diretor;

c) Supervisor;

d) Coordenador Pedagógico Local.

35 - Para suprir carência nos Centros Interescolares de Línguas, Centros de Educação Profissional, na Educação Especial, nos atendimentos previstos na modulação da UE, nas Unidades de Internação, na Escola Parque da Cidade - PROEM, na Escola Meninos e Meninas do Parque, nos Centros de Iniciação Desportiva, nas Ginásticas nas Quadras, no Centro Integrado de Educação Física, nas UE que ofertam Educação em Movimento, o servidor deverá submeter-se a entrevista prévia conforme especificado em edital.

36 - As carências apresentadas e disponíveis para bloqueio serão de 20 horas semanais nos diversos turnos ou de 40 horas semanais, seja jornada ampliada ou 20 mais 20 horas.

TÍTULO IV

\section{DAS DISPOSIÇÕES GERAIS}

37 - Terá assegurado o retorno à UE de origem, o servidor afastado em virtude de:

a) afastamentos previstos no art. 132 da Lei Complementar $n^{\circ} 840$, de 23 de dezembro de 2011

b) férias regulamentares;

c) licença à gestante;

d) licença para atividade política;

e) licença para tratamento de saúde,

f) licença por motivo de doença em pessoa da família, por até 06 (seis) meses;

g) licença-prêmio por assiduidade;

h) nomeação para cargo em comissão ou indicação para atividade técnica ou pedagógica no âmbito da mesma UE, desde que tenha participado no procedimento de escolha de turmas no referido ano letivo; 
i) licença remunerada para estudos, por até 06 (seis) meses.

37.1 - Os casos especificados no item 37 se aplicam a quem possui exercício definitivo na UE no ano em que retornar do afastamento.

38 - O servidor que for encaminhado para a UE, ao longo do ano letivo, para suprir carências provisórias ou definitivas, para atuar em coordenação pedagógica local, em atividades técnicas pedagógicas ou administrativas, ou apenas para exercer função gratificada não terá o seu exercício na UE.

39 - O servidor com cargo comissionado na SEDF e nas CRE, quando de sua exoneração, será devolvido à CRE de lotação para ser encaminhado a um novo local de exercício, de acordo com as carências existentes, respeitada sua jornada de trabalho.

40 - O professor remanejado estará sujeito às normas de distribuição de carga horária vigentes, à época, na nova UE de exercício.

41 - O servidor que se encontrar na situação de excedentedeverá ser movimentado de uma UE para outra, no decorrer do ano letivo, de acordo com a necessidade da CRE.

42 - O servidor readaptado que em seu Laudo de Capacidade Laborativa, emitido pela COSAÚDE, tiver expressa a necessidade de atuação próxima a sua residência registrada no SIGRH, deverá requerer seu remanejamento, anexando cópia deste Laudo.

42.1 - Nessas condições será assegurada a movimentação para a CRE que atenda as necessidades do servidor, observada sua anuência, bem como a conveniência da Administração.

43 - Caso seja criadas UE de atendimento diferenciado, a SEDF editará normas próprias que regulem a movimentação dos servidores para atender a estratégia de matrícula e a modulação das referidas unidades.

44 - O servidor não poderá ser remanejado em desacordo com o disposto nestas normas.

45 - A responsabilidade pela homologação dos dados apresentados no sistema é do servidor. 46 - O procedimento de Remanejamento Externo e Interno será regulamentado por edital a ser publicado no Diário Oficial do Distrito Federal.

47 - Aos servidores participantes e os responsáveis pela operacionalização destas normas, caso não sejam cumpridas, serão aplicadas, no que couber, as sanções disciplinares previstas na Lei Complementar no 840, de 23 de dezembro de 2011.

48 - Os casos omissos serão resolvidos pelo Secretário de Estado de Educação do Distrito Federal.

Fonte: Diário Oficial do Distrito Federal n 217 do dia 15/10/2014 - Seção 01. 


\section{Integração à Carreira Magistério Educação Infantil/Anos Iniciais}

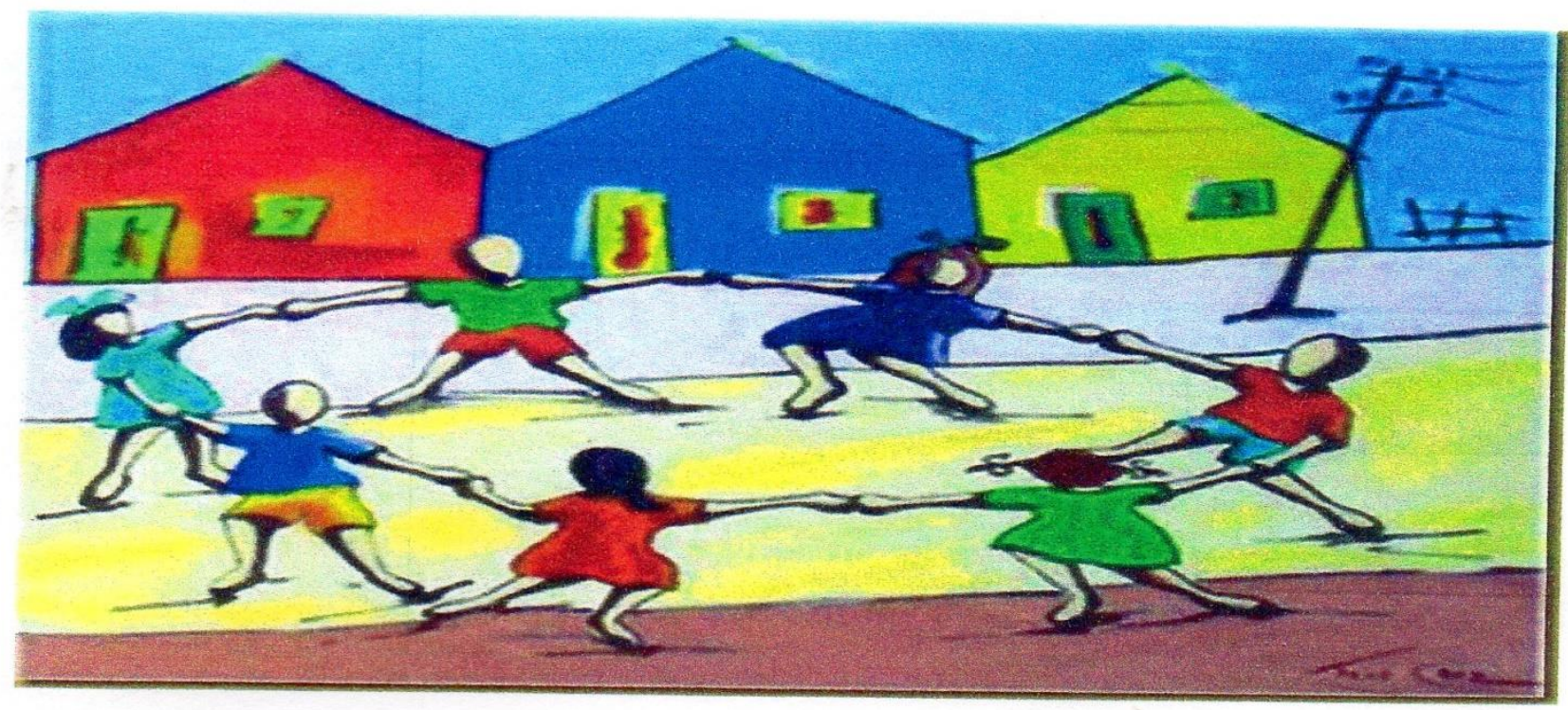

Este curso é uma exigência do artigo 11 da Lei 5.105/13, que determina a oferta de um curso de integração aos(às) professores(as) ingressantes na rede pública de ensino do Distrito Federal. O curso tem como objetivo principal discutir aspectos dos documentos norteadores da educação pública da SEEDF, bem como os aspectos referentes à atuação docente, a fim de contribuir para a construção de uma identidade profissional que favoreça a percepção do sujeitodocente como protagonista de ações que busquem consolidar uma educação pública de qualidade social, coerente com a política educacional vigente.

Carga horária: $60 \mathrm{~h}$

Vagas: 60

Modalidade: presencial

Público: Exclusivamente professores(as) que ingressaram, em 2013 e em 2014, na Carreira Magistério Público no Distrito Federal

Local: EAPE (terça-feira - vespertino) e Polo Taguatinga (terça-feira - matutino)

Formadoras: Aline Sampaio de Oliveira e Débora Avelina Felipe

Para obter outras informações e para realizar inscrição, acesse a Circular $n^{\circ}$ 140/2015 no site http://www.eape.se.df.gov.br até o dia 15/07/2015 


\section{Integração à Carreira Magistério \\ Anos Finais}

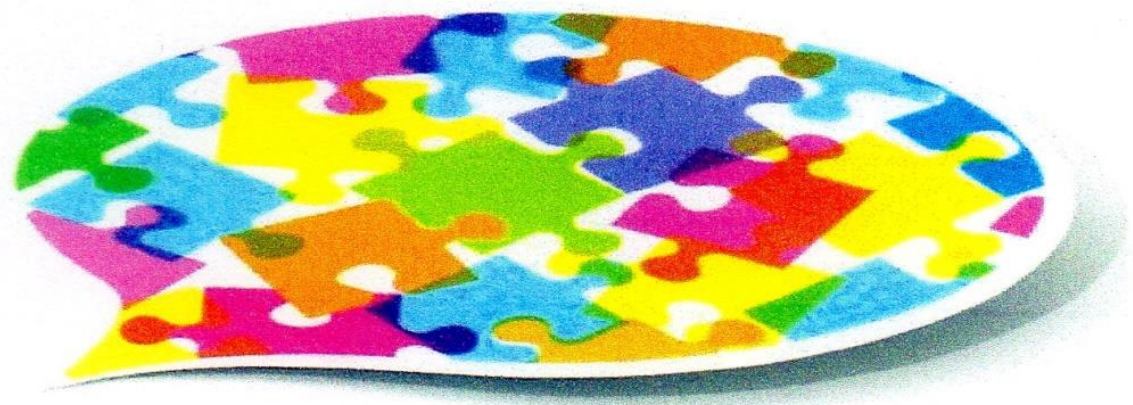

A oferta do curso atende a uma exigência legal estabelecida na Lei 5.105 de 2013, que reestrutura a carreira do Magistério Público do Distrito Federal. Conhecida como lei do Plano de Carreira, esse instrumento legal assegura, no seu Capítulo II (Do Desenvolvimento Funcional), Seção I (Da Qualificação Profissional), em seu artigo 11, que a "Secretaria de Estado de Educação implementará para os servidores em estágio probatório Curso de Integração à Carreira Magistério Público do Distrito Federal e programas de acompanhamento e avaliação." Assim, ao ofertar o curso Integração à Carreira Magistério - Ensino Fundamental/Anos Finais, busca contribuir com o processo de formação continuada dos(as) profissionais da carreira docente, notadamente no que diz respeito ao que preconizam os documentos norteadores da educação pública no Distrito Federal. As temáticas que compõem a organização curricular do curso são as seguintes: Eixos Transversais do Curriculo em Movimento (Diversidade, Direitos Humanos e Cidadania e Sustentabilidade) e Eixos Integradores (Ludicidade e Letramentos) e Princípios Epistemológicos do Currículo Integrado (Teoria e Prática, Flexibilizaçäo e Interdisciplinaridade e Contextualização). O princípio da interdisciplinaridade e o eixo integrador dos letramentos serão os processos por meio dos quais o curso buscará a integração entre as áreas de Matemática e Ciências Humanas.

Carga Horária: 60h

Vagas: 150

Modalidade: Presencial

Público: Exclusivamente para professores(as) do Ensino Fundamental (Anos Finais), atuantes em qualquer uma das áreas de conhecimento, que ingressaram na SEEDF nos anos de 2013 e 2014.

Local: EAPE (Segunda-feira - matutino, Terça-feira - vespertino); Taguatinga (Segunda-feira vespertino); Paranoá (Segunda-feira, matutino/vespertino).

Formadores(as): André Lúcio Bento e Marcelo de Ataíde Ferreira.

Para obter outras informaçōes e para realizar inscrição, acesse a Circular $n^{0}$ 143/2015 no site http://www.eape.se.df.gov.br até o dia 15/07/2015. 


\section{Integração à Carreira Magistério Anos Finais: Área de Linguagens, Códigos e suas Tecnologias}

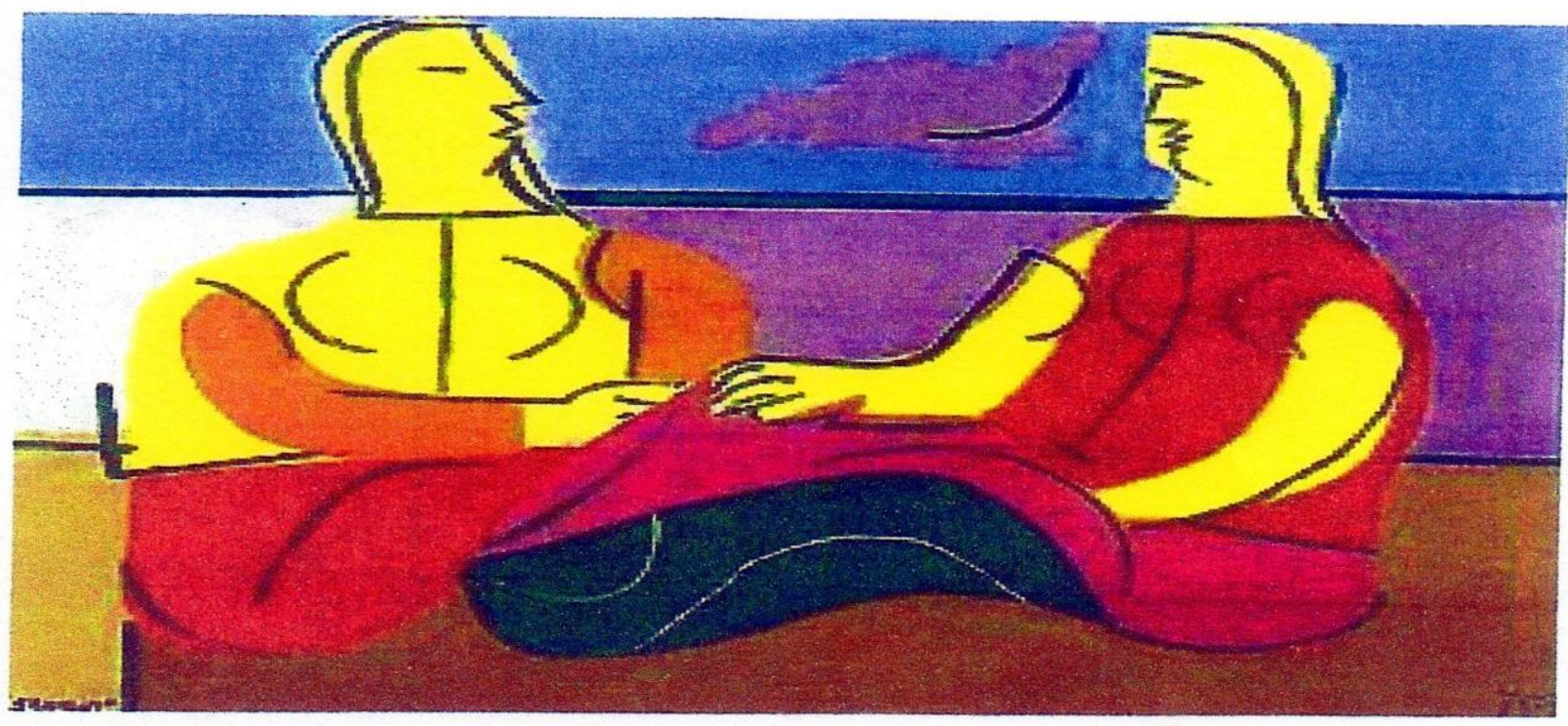

A oferta do curso se dá em consonância à exigência legal, conforme observado no Plano de Carreira Magistério Público do Distrito Federal (Lei 5.105 de 2013), CAPITULO II (DO DESENVOLVIMENTO FUNCIONAL), Seção I (Da Qualificação Profissional), em seu artigo 11, onde se lê: "A Secretaria de Estado de Educação implementará para os servidores em estágio probatório Curso de Integração à Carreira Magistério Público do Distrito Federal e programas de acompanhamento e avaliação." (BRASIL, 2013, p.05). O objetivo do curso é propiciar ao (à) professor(a) recém-ingresso(a) na SEDF uma reflexäo sobre a formaçāo do leitor, vinculada aos Pressupostos Teóricos do Currículo em Movimento da Educação Básica (2014), considerando, de modo especial, os eixos transversais como temáticas/questöes que perpassam o conteúdo curricular, no seu sentido mais amplo, bem como as Diretrizes de Avaliaçäo(2014), na perspectiva de contribuir para a prática pedagógica desse profissional.

No que concerne mais especificamente à área de Linguagens, Códigos e suas Tecnologias e sua relação com a questāo da leitura, deve-se considerar que formar um leitor é capacitar o individuo para, além de decodificar um texto, perceber as suas sutilezas, avaliá-lo criticamente, interpretá-lo em perspectiva com outros textos.

\section{Carga Horária: 60h}

Vagas: 60

Modalidade: Presencial

Público: Exclusivamente para professores(as) atuantes em Anos Finais, Área de Linguagens, Códigos e suas Tecnologias, ingressos na SEEDF nos anos 2013 e 2014.

Local: EAPE (Segunda-feira - matutino, vespertino).

Formadores(as): Simone Rodrigues do Amaral.

Para obter outras informaçōes e para realizar inscrição, acesse a Circular n 146/2015 no site http://www.eape.se.df.gov.br até o dia 15/07/2015. 


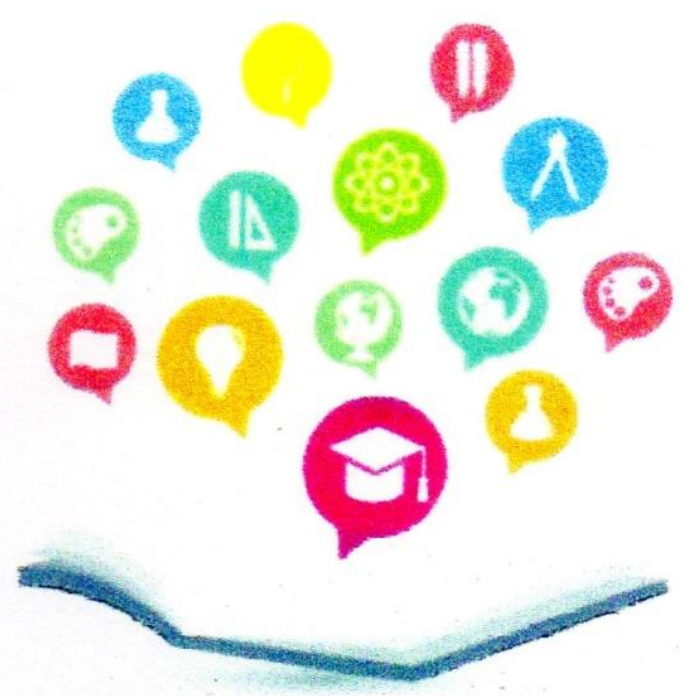

O curso Integragäo à Carreira Magistério - Ensino Médio e EJA tem como objetivo possibilitar aos(as) professores(as) ingressantes na SEDF, nos anos de 2013 e 2014, que atuam no Ensino Médio noturno e na Educação de Jovens e Adultos, reflexōes acerca dos pressupostos teóricos do Curriculo em Movimento da Educaçäo Básica e de seus impactos nas práticas pedagógicas em todas as áreas do conhecimento. A oferta do curso atende a uma exigência legal estabelecida na Lei 5.105 de 2013, que reestrutura a carreira do Magistério Público do Distrito Federal. O princípio da interdisciplinaridade e a perspectiva dos multiletramentos serão os processos por meio dos quais o curso buscará a integração entre todas as áreas do conhecimento.

Carga horária: 60h

Vagas: $\mathbf{3 0}$

Modalidade: A distância (02 encontros presenciais)

Público: Exclusivamente para professores(as) do Ensino Médio e Educaçäo de Jovens e Adultos/ 3 Segmento, atuantes em qualquer área do conhecimento, no tumo notumo, que ingressaram na SEDF nos anos de 2013 e 2014.

Local: EAPE (Terga, quarta ou quinta-feira - notumo)

Formadora: André Lúcio Bento

Para obter outras informaçōes e para realizar inscriçäo, acesse a circular $n^{\circ}$ 136/2015 no site http://www.eape.se.df.gov.br/ até o dia 15/07/2015 


\section{Gestão Escolar Democrática: das Políticas Públicas ao Projeto Político-Pedagógico da Escola}

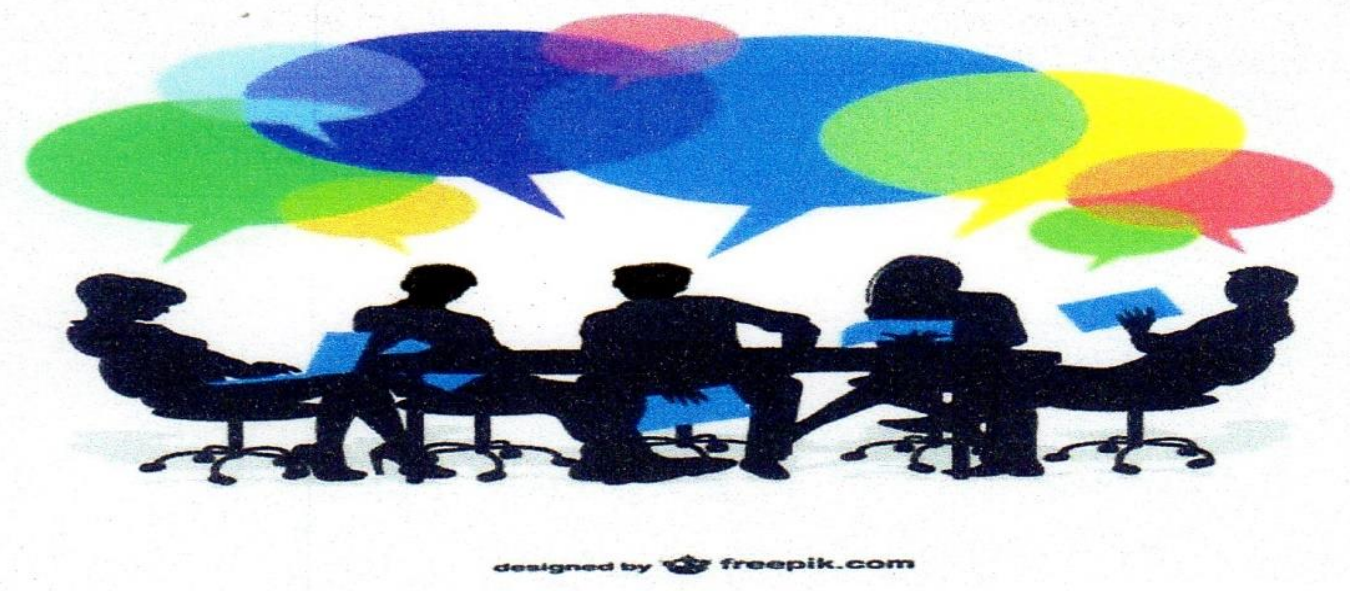

Diante dos complexos desafios educacionais do século $X X I$, é necessária uma formação continuada para os(as) diretores(as) das escolas públicas que tenha como base: a) a Gestão Democrática (Lei 4.751/2012), que, a rigor, estabelece a necessidade de envolvimento de toda a comunidade escolar nos processos escolares; b) os Saberes e as Práticas Escolares, uma vez que é imprescindivel dominar o conhecimento acumulado pela humanidade e ao mesmo tempo articulá-lo com o mundo real que "habita" a escola; e c) os Pressupostos Norteadores da SEEDF, atualmente presentes no Currículo, nas Orientações Pedagógicas, nas Diretrizes (pedagógicas e de avaliação) e em outros documentos. Assim, este curso busca aprofundar conhecimentos relacionados à compreensão da democracia e da democracia escolar, às categorias teóricas e a aspectos referentes à reorganizaçāo e organizaçāo do trabalho pedagógico. Para dar centralidade aos pressupostos norteadores, em especial o Currículo, o curso desenvolverá suas atividades com base na Pedagogia Histórico-Crítica e na Psicologia Histórico-Cultural.

Carga horária: $180 \mathrm{~h}$

Vagas: 660

Modalidade: A distância (com 07 encontros presenciais)

Público: exclusivamente diretores(as) e vice-diretores(as) das unidades escolares da rede pública de ensino do Distrito Federal

Formadores: Angela Anastácio Silva, Edileuza Fernandes da Silva, Helane Araujo Lima, Henrique Rodrigues Torres, Janete Mafra, Michelle Campelo Costa, Ricardo Gonçalves Pacheco, Sonaly Carvalho de Miranda Silva

Para obter outras informações e para realizar inscrição, acesse a circular $n^{\circ} 167 / 2015$ no site http://www.eape.se.df.gov.br até o dia 15/07/2015. 